\title{
BIOGEOQUÍMICA DE ELEMENTOS TRAÇO EM SOLOS DE SISTEMAS ESTUARINOS: MANGUEZAIS DO ESTADO DE SÃO PAULO (BRASIL) E MARISMAS DA GALÍCIA (ESPANHA).
}

\author{
Maria Luiza de Souza Silva \\ Bacharel em Química
}

Orientador: Prof. Dr. PABLO VIDAL TORRADO

\begin{abstract}
Tese apresentada à Escola Superior de Agricultura
"Luiz de Queiroz", Universidade de São Paulo, para obtenção do título de Doutor em Agronomia, Área de Concentração: Solos e Nutrição de Plantas.
\end{abstract}

PIR A C IC A B A

Estado de São Paulo - Brasil

Janeiro - 2005 
Silva, Maria Luiza de Souza

Biogeoquímica de elementos traço em solos de sistemas estuarinos: manguezais do Estado de São Paulo (Brasil) e Marismas da Galícia (Espanha) / Maria Luiza de Souza Silva. - - Piracicaba, 2005

147 p. : il.

Tese (Doutorado) - - Escola Superior de Agricultura Luiz de Queiroz, 2005.

Bibliografia.

1. Biogeoquímica 2. Ecologia 3. Ecossistema estuarino 4. Elemento traço 5 . Impacto ambiental 6. Limnologia 7. Pedologia 8. Relação solo-vegetação 9 . Uso do solo I. Título

CDD 631.4 


\section{OFEREÇO}

A Deus e à Espiritualidade Amiga.

"Se te propões à realização de qualquer tarefa vinculada à construção do bem, conta com problemas e dificuldades que te habilitem as forças para isso. Luta é o outro lado da vitória. Lembra-te: o aço é o ferro trabalhado pelo fogo. As boas obras nascem do amor temperado pelo sofrimento" (Emmanuel).

\section{DEDICO}

Aos meus pais, Mauro e Lourdes, pelos ensinamentos, exemplo de vida e apoio. Aos meus irmãos, Marco Antônio, Angélica e Ligia, pelo apoio e incentivo. Ao meu namorado, Maximiliano, pelo apoio e confiança. Foi com amor e compreensão que me motivaram a transpor todos os desafios encontrados nesta etapa da minha vida. 


\section{AGRADECIMENTOS}

Ao Prof. Dr. Pablo Vidal Torrado pela orientação, apoio e incentivo durante estes anos de trabalho;

Ao Prof. Dr. Xosé Luis Otero Perez (Universidade de Santiago de Compostela), pela orientação no exterior, amizade, confiança, incentivo e apoio na concretização deste trabalho;

Ao Prof. Dr. Felipe Macias"Vasquez (Universidade de Santiago de Compostela), pelas facilidades concedidas nas análises realizadas na Espanha e pela colaboração ao projeto;

Ao $\mathrm{CNPq}$, pela concessão da Bolsa de estudo no país;

À $\mathrm{CAPES}^{1}$, pela concessão da Bolsa no exterior;

À coordenação do curso de Pós-Graduação em Solos e Nutrição de Plantas (ESALQ/USP), pela oportunidade oferecida;

À Universidade de Santiago de Compostela, pela oportunidade de realização do doutorado com estágio no exterior;

Aos funcionários da Esalq e da USC, pelo convívio, amizade e auxílio nas diversas etapas do trabalho, em especial à Maria José Santiso (Universidade de Santiago de Compostela), pela paciência e auxílio nas análises laboratoriais.

\footnotetext{
${ }^{1}$ Esta tese de doutorado faz parte das atividades do Projeto Pedologia e comportamento de metais pesados e contaminantes orgânicos em solos de ambientes estuarinos de clima tropical (Manguezais, Brasil) e de clima temperado (Marismas, Espanha) dentro do convênio Brasil/Espanha CAPES /MECDDGU.
} 
Ao Tiago e ao Prof. Dr. Miguel Cooper pelo auxílio na confecção do summary. Aos colegas do grupo de pesquisa pelo apoio e companheirismo.

Aos colegas de curso, pela amizade e convivência;

À todos os meus amigos e amigas, os velhos e os novos, os de perto e os de longe, pelos momentos de alegria e pelo companheirismo nos momentos difíceis.

À todos aqueles que direta e indiretamente ajudaram na realização desse trabalho. 


\section{SUMÁRIO}

Página

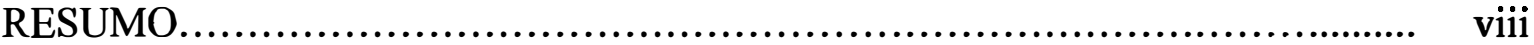

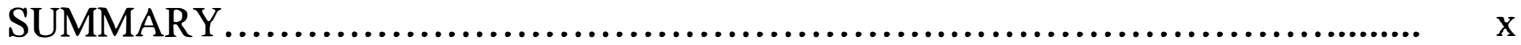

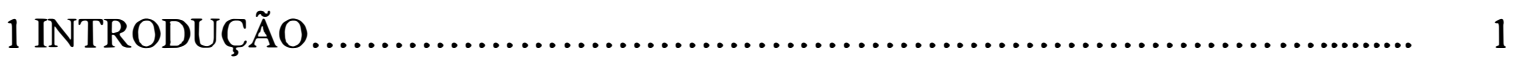

2 REVISÃO DE LITERATURA................................................... 8

2.1 Caracterização do ecossistema de manguezal............................................................. 8

2.1.1 Solos de manguezal........................................................................................ 9

2.1.2 Vegetação de Mangue................................................................................................... 11

2.1.2.1 Principais espécies de mangue............................................................................ 12

2.1.3 Relação solo - vegetação......................................................................................... 13

2.2 Caracterização do ecossistema de marisma................................................................ 15

2.2.1 Fisiografia da marisma.......................................................................................... 15

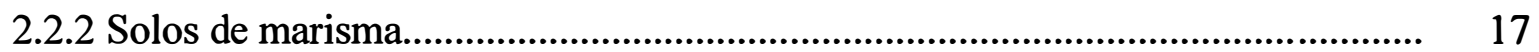

2.2.3 Vegetação de marisma............................................................................................... 19

2.3 Processos redox em solos de sistemas estuarinos........................................................ $\quad 20$

2.4 Elementos traço em solos de manguezais e marismas................................................ 27

3 MATERIAL E MÉTODOS................................................................................ 34

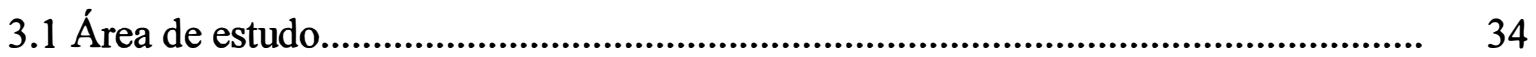

3.1.1 Ambiente estuarino de clima tropical (Brasil)........................................................ 34

3.1.2 Ambiente estuarino de clima temperado (Espanha).............................................. 36

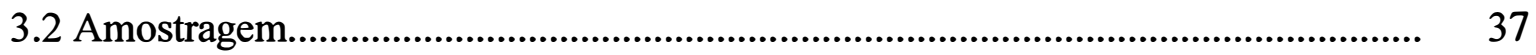

3.2.1 Manguezais do Estado de São Paulo........................................................................ 37 


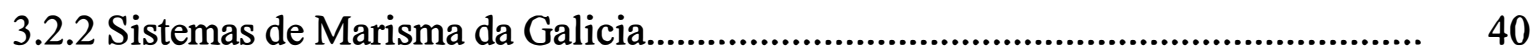

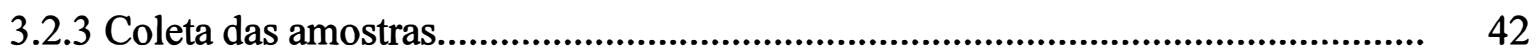

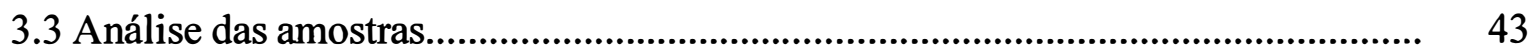

4 RESULTADOS E DISCUSSÃO......................................................................... 47

4.1 Caracterização e conteúdo total de elementos traço nos solos de manguezais e marisma.

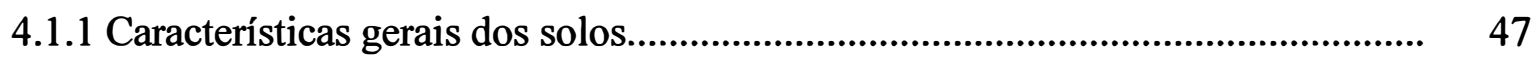

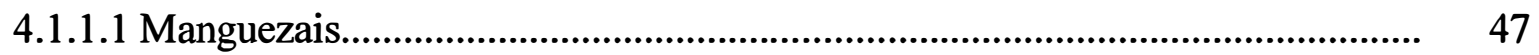

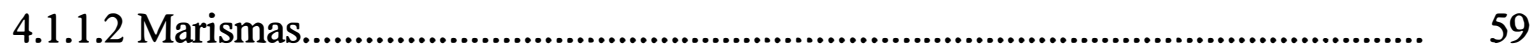

4.1.2 Sulfetos voláteis em meio ácido (AVS)............................................................ 61

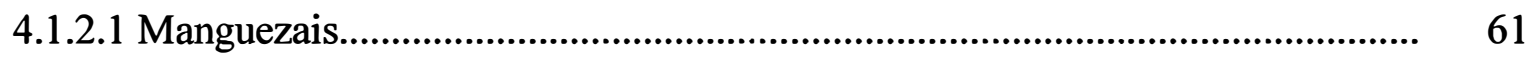

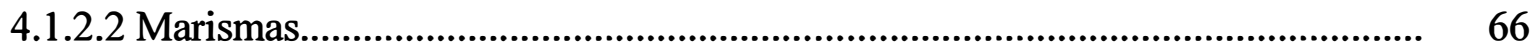

4.1.3 Conteúdo total dos elementos traço.......................................................................... 69

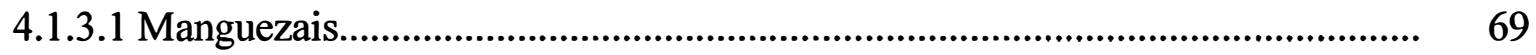

4.1.3.2 Marismas........................................................................................................ 74

4.2 Comportamento geoquímico de elementos traço em solos de manguezais e de marisma..

4.2.1 Comportamento geoquímico do Fe.................................................................... 78

4.2.2 Comportamento Geoquímico do Mn.................................................................. 85

4.2.3 Comportamento geoquímico do Mercúrio.............................................................. 93

4.2.4 Comportamento geoquímico do Crómio................................................................... 101

4.2.5 Comportamento geoquímico do Níquel.............................................................. 109

4.2.6 Comportamento geoquímico do Cobre.............................................................. 114

4.2.7 Comportamento geoquímico do Zinco.................................................................. 117

5 CONCLUSÕES....................................................................................... 122

REFERÊNCIAS BIBLIOGRÁFICAS............................................................. 124 


\title{
BIOGEOQUÍMICA DE ELEMENTOS TRAÇO EM SOLOS DE SISTEMAS ESTUARINOS: MANGUEZAIS DO ESTADO DE SÃO PAULO (BRASIL) E MARISMAS DA GALÍCIA (ESPANHA)
}

\author{
Autora: MARIA LUIZA DE SOUZA SILVA \\ Orientador: Prof. Dr. PABLO VIDAL TORRADO
}

\section{RESUMO}

O uso de um largo espectro de substâncias químicas em atividades humanas, domésticas e industriais, aliados a direção preferencial do desenvolvimento em áreas costeiras, continua contribuindo para a contaminação ambiental com importante incremento na concentração dos elementos traço. Uma vez que a acumulação destes elementos traço em sistemas estuarinos é um processo que depende basicamente de alterações nos estados de oxi-redução na interface água-solo, fatores que alterem as condições biogeoquímicas do solo alterarão também as taxas de acumulação de elementos traço nos solos destes ambientes. O presente estudo foi proposto com $o$ objetivo principal de estabelecer o comportamento geoquímico de diversos elementos traço relacionado à geoquímica do Fe e $\mathrm{S}$ em solos de sistemas estuarinos de clima tropical (manguezais) e de sistemas estuarinos de clima temperado (marismas) com diferentes graus e tipos de contaminação, como também, de verificar os níveis de base dos elementos traço nos solos dos manguezais e das marismas. O material do trabalho 
foi composto por 15 perfis de solos procedentes de diferentes manguezais do litoral paulista, sendo 11 destes pertencentes a Baixada Santista, os quais apresentam diferentes tipos de impactos antrópicos e os outros 4 perfis de solos pertencentes a Ilha do Cardoso, a qual se apresenta livre de impacto antrópico, e por 5 perfis de solos procedentes dos sistemas de marisma da Costa da Galícia (Espanha). Foram determinados $\mathrm{pH}$, potencial redox (Eh), conteúdo de carbono orgânico total (TOC), $\mathrm{S}$ total, $\mathrm{N}$ total, conteúdo total e fracionamento dos elementos traço nos solos. $\mathrm{O}$ método de fracionamento seguido para os metais traço foi uma combinação de métodos anteriormente propostos para meios sedimentares, cuja aplicação permitiu diferenciar com maior precisão a fração pirítica. Os solos de manguezais se caracterizaram por apresentar uma ampla variação em seu conteúdo em matéria orgânica e o $\mathrm{pH}$ situou-se próximo à neutralidade. As condições de oxidação-redução dominantes nos solos de manguezais foram anóxicas em superfície, inclusive, enquanto que os solos das marismas mostraram uma variabilidade muito mais ampla, oscilando entre condições óxicas a anóxicas. Comparando os solos dos dois sistemas estudados, os das marismas apresentaram um grau de enriquecimento em elementos traço maior que o dos solos dos manguezais. A piritização do $\mathrm{Fe}$, do $\mathrm{Mn}$ e dos elementos traço considerados, foi muito mais intensa nos solos de manguezais do que nos das marismas. Independentemente do tipo de ambiente (marisma ou manguezal), a incorporação dos elementos traço à fração pirítica não depende unicamente das condições redox dos solos, mas também do comportamento geoquímico de cada elemento em particular. Ainda que todos os metais considerados tenham apresentado correlações significativas com o Fe pirítico, o grau de piritização foi muito diferente para cada um deles. Neste sentido a ordem de incorporação dos metais traço na fração pirítica foi $\mathrm{Cu} \gg>\mathrm{Ni}>\mathrm{Zn} \sim \mathrm{Cr}>\mathrm{Hg}$. Porém, deve-se ressaltar que os resultados de piritização obtidos para o $\mathrm{Zn}$ podem estar subestimados, uma vez que o $\mathrm{ZnS}$ é soluvel em meio ácido. Quanto ao $\mathrm{Hg}$, este elemento deve ser objeto de futuros estudos mais específicos, onde se considerem outras formas geoquímicas como o $\mathrm{Hg}$ elementar. 


\title{
BIOGEOGHEMISTRY OF TRACE ELEMENTS IN SOILS FROM ESTUARINE SYSTEMS: MANGROVES FROM SÃO PAULO STATE (BRAZIL) AND SALT- MARSHES FROM GALÍCIA (SPAIN)
}

\author{
Author: MARIA LUIZA DE SOUZA SILVA \\ Adviser: Prof. Dr. PABLO VIDAL TORRADO
}

\section{SUMMARY}

The use of a wide spectrum of chemical substances in human activities (domestic and industrial) allied to the preferential direction of the development in coastal areas, contribute to environment contamination with important increment in trace elements concentration. Since the process of trace elements accumulation in estuarine systems depends on oxi-reduction alterations at soil-water interface, factors that modify biogeochemical conditions of soil will modify the accumulation rates of trace elements in these environments. The objectives of this study were to establish the geochemical behavior of trace elements related to $\mathrm{Fe}$ and $\mathrm{S}$ geochemistry in tropical (mangrove) and temperate (salt-marshes) estuarine soils with different degrees and types of contamination, and also, to verify the critical levels of trace elements in these soils. The study was developed in 15 soil profiles from different mangroves at the São Paulo State (Brazil) and 5 soil profiles from salt marshes in Galicia (Spain). Eleven mangrove soils presented some kind of human impact while four were free from any human interference. Redox potential (Eh), $\mathrm{pH}$, total organic carbon content (TOC), total $\mathrm{S}$, total 
$\mathrm{N}$, total trace elements concentration and speciation of trace elements were assed. Speciation of trace elements was determined using a combined method of sequentialextraction which allowed a precise determination of pyritic iron. Physico-chemical conditions in mangrove soils were marked by $\mathrm{pH}$ values close to neutrality and by anoxia (negative Eh values in all layers), while salt marshes soils showed $\mathrm{Eh}$ and $\mathrm{pH}$ values varying within a broader interval (anoxic and oxidizing conditions). Salt marshes soils presented a higher enrichment degree of trace elements while pyritization of $\mathrm{Fe}$, $\mathrm{Mn}$ and trace elements was higher in mangrove soils. In both environments pyritization seemed to be ruled by the distinct geochemical behavior of each trace element. Although significant correlations between piritic-Fe and trace elements were found, the degree of pyritization was very different for each one of them. Incorporation of trace elements to pyritic fraction followed the order $\mathrm{Cu} \gg>\mathrm{Ni}>\mathrm{Zn} \sim \mathrm{Cr}>\mathrm{Hg}$, however, values of $\mathrm{Zn}$ pyritization may have been underestimated since $\mathrm{ZnS}$ is soluble in acid media. We also show the need of further studies on $\mathrm{Hg}$ geochemical behavior and the importance of considering elemental $\mathrm{Hg}$ in order to obtain more reliable results. 


\section{INTRODUÇÃO}

Os elementos traço são um constituinte natural em rochas, solos, sedimentos e águas, entretanto, sua concentração tem sido notavelmente incrementada nos sistemas superficiais desde a revolução industrial. Pode-se dizer que mundialmente, este enriquecimento tem provocado em alguns casos, graves problemas ambientais, afetando a cadeia trófica e a saúde de animais e pessoas.

As descargas de resíduos industriais, agrícolas e urbanos são consideradas como as principais fontes de contaminação dos ecossistemas costeiros.

O Brasil hoje apresenta problemas de ordem sanitária e de desequilíbrio ecológico devido à atividade antropogênica, que adquire uma especial relevância na região litorânea. O lançamento de poluentes, especialmente elementos traço, petróleo e derivados, em lagoas, estuários e baías têm causado impactos ambientais que se manifestam de diferentes formas, de acordo com as características dos efluentes e da complexidade de cada ecossistema. Tais impactos podem alterar a produtividade e a estrutura das comunidades biológicas, podendo causar extinções locais de populações animais e vegetais. No caso de petróleo e seus derivados, em princípio, seus efeitos são reversíveis e sua contaminação biodegradável. No caso de elementos traço, entretanto, a contaminação é praticamente irreversível e seus efeitos podem se expressar durante séculos. A contaminação por elementos traço é, talvez, o principal passivo ambiental deixado pela atividade industrial e mineradora dos últimos 200 anos (Nriagu, 1996).

Os ecossistemas de manguezal e as planícies de maré associadas são os habitats mais importantes das regiões costeiras tropicais, não só por sua importância econômica e ecológica, mas por serem um dos ambientes mais afetados por atividades humanas. $\mathrm{O}$ ecossistema de manguezal geralmente está associado às margens de baías, enseadas, 
barras, desembocaduras de rios, lagunas e reentrâncias costeiras, onde haja encontro de águas de rios com o mar ou diretamente expostos à linha da costa (Schaeffer-Novelli, 1999). É um sistema especial, com substrato pouco conhecido, ao qual os estudiosos das áreas de ecologia, oceanografia e poluição se referem freqüentemente como sedimento. Por se tratar de substrato que sustenta vegetação os pedólogos o tratam como solo, porém com pouca precisão em relação à sua classificação. De fato, muitos estudos pedológicos os denominam como solos indiscriminados de manguezais, incluindo gleissolos salinos e organossolos, ambos normalmente com caráter tiomórfico (PradaGamero et al., 2004).

Os manguezais consistem no elo entre o ambiente terrestre, os rios e o oceano e desempenham importante papel econômico em regiões tropicais costeiras, de modo a fornecer benefícios para a população humana local, principalmente para os pescadores artesanais (Vannucci, 1999). As condições oceanográficas das florestas de mangue tipicamente formadas em regiões estuarinas, nas zonas entre-marés, promovem o acúmulo de sedimentos finos oceânicos, fluviais e terrestres, favorecendo o desenvolvimento desse ecossistema florestal de características tão singulares.

Áreas litorâneas tropicais e algumas subtropicais protegidas da ação das ondas, e que recebem do continente, águas doces com sedimentos e nutrientes, são propícias ao crescimento de manguezais. Tais ecossistemas, formados por plantas adaptadas a condições de estresse - inundações periódicas pela água do mar, solo frouxo, variações de salinidade e baixos teores de oxigênio, produzem grande quantidade de matéria orgânica e a exportam, o que favorece o aumento da produtividade pesqueira de mares próximos. No entanto, apesar do seu valor e das leis de proteção, os manguezais têm sido destruídos (Menezes et al., 2000).

Embora haja um número considerável de estudos biogeoquímicos em manguezais no litoral brasileiro, particularmente de manguezais do Estado do Rio de Janeiro e da região norte do Brasil (Lacerda \& Abrão, 1984; Lacerda et al., 1995; Molisani et al., 1999; Rezende et al., 2002; Lacerda et al., 2004; Marins et al., 2004), há necessidade de um maior número de estudos de casos, pois estes sistemas desempenham importante função na ciclagem regional e global de carbono, nutrientes e elementos 
traço, interagindo ativamente nas trocas entre os ambientes terrestre e marinho. Uma vez que o desenvolvimento industrial nos trópicos ocorre em grande parte no litoral, os manguezais podem desempenhar importante papel na dinâmica de poluentes nestas áreas. As condições hidrológicas e pedológicas dominantes nesses ecossistemas estão diretamente envolvidas na capacidade de acumulação de metais pelos manguezais (Lacerda, 2001).

$\mathrm{O}$ uso de um largo espectro de substâncias químicas em atividades humanas, domésticas e industriais, aliados a direção preferencial do desenvolvimento em áreas costeiras, tem contribuído para a contaminação ambiental com importante incremento dos elementos traço. Assim, não é surpresa que os ecossistemas costeiros estejam ameaçados por impactos ambientais.

No Brasil, as regiões costeiras, em geral, tendem a apresentar uma intensa ocupação urbana, o que ocasiona sérias perturbações aos ecossistemas que aí se encontram. A Baixada Santista abriga um importante pólo industrial do país, situado em Cubatão e o maior porto da América Latina, o Porto de Santos, os quais contribuíram para a degradação ambiental principalmente dos sistemas estuarinos de Santos e São Vicente.

A proximidade com a região metropolitana de São Paulo, a construção de uma desenvolvida infra-estrutura de transporte rodoviário, ferroviário e portuário, e a disponibilidade local de água e energia elétrica levou, a partir da década de 50 , à implantação de diversas indústrias de base (siderurgia, petroquímica, fertilizantes) em meio a uma ampla rede de canais estuarinos e extensos manguezais, confinados entre o oceano e as escarpas da Serrra do Mar. Esta atividade industrial, de alto potencial poluidor, fez dos estuários de Santos e São Vicente grandes receptores de resíduos tóxicos e efluentes líquidos contaminados. Os poluentes industriais, juntamente com os resíduos e esgotos do Porto de Santos e das cidades da região, provocaram um grave quadro de degradação ambiental. Este cenário foi agravado, ainda, pela disposição de resíduos sólidos industriais e domésticos em locais impróprios, além dos freqüentes acidentes com derramamentos de óleo e outras substâncias tóxicas nos cursos d'água. (CETESB, 1979; Tommasi, 1979). 
A região da Baixada Santista é, sem dúvida, a que apresenta o maior grau de degradação, pois é intensamente ocupada por processos industriais, urbanos e por atividades portuárias, submetendo-se desta forma a distintas fontes de poluentes, que alteram seriamente a qualidade ambiental da região (Ferrer, 2001).

Como causas de degradação destes sistemas foram apontadas a poluição de origem doméstica e a industrial, ambas responsáveis pela contaminação química e microbiológica, e as alterações físicas dos habitats resultantes de processos de erosão, assoreamento, aterros de canais e manguezais e intervenções no sistema de drenagem.

Com a intensa atividade industrial, principalmente nos municípios de Cubatão, Santos e Guarujá, onde se encontram grandes complexos industriais (químicos, petroquímicos, siderúrgicos, etc.), os riscos são permanentes tanto para o solo quanto para a água e o ar, afetando todo o ambiente e a qualidade de vida dessa região. Ademais, destacam-se, as atividades geradas pelo Porto de Santos, o maior do Brasil, onde diariamente inúmeros navios carregam e descarregam produtos oriundos de vários países, como matérias-primas e produtos industrializados. Muitos desses produtos são armazenados em tanques e comercializados de acordo com a demanda. Esse procedimento, juntamente com as demais atividades marítimas realizadas no porto, torna os acidentes ambientais comuns, por exemplo, derramamento de produtos químicos (CETESB, 2004).

Os processos de degradação dos ecossistemas costeiros e os efeitos deletérios da poluição começaram a reverter somente a partir de 1984, quando a Companhia de Tecnologia de Saneamento Ambiental de São Paulo (CETESB), introduziu no pólo industrial de Cubatão, um intensivo programa de controle da poluição do ar, das águas e do solo.

A implantação de sistemas de tratamento de efluentes industriais em todas as fábricas da região, resultou em acentuada redução da carga de poluentes para o sistema hídrico. Teve início, então, um gradativo processo de recuperação dos ecossistemas aquáticos e estuarinos, com o aumento da diversidade de aves, organismos aquáticos e a intensificação da pesca. Apesar do grande esforço para o controle da poluição e melhoria da qualidade ambiental, os levantamentos realizados na década de noventa apontavam a 
persistência de problemas de acumulação de poluentes nos sedimentos e potencialmente os de contaminação da biota, pondo em risco a saúde pública e o equilíbrio ecológico dos ecossistemas costeiros da região.

Para que as atividades do porto aconteçam, há a necessidade da dragagem periódica dos canais de navegação, tanto do Porto de Santos, quanto do canal particular da COSIPA para dar condições de navegação aos navios que ali trafegam. Em função da natureza desse material, desde 1996 é realizado o gerenciamento da qualidade do mesmo que, atendendo aos requisitos ambientais, é disposto em local específico, autorizado pela Marinha, a cerca de $13 \mathrm{~km}$ da entrada do Canal de Santos, nas imediações da Ponta do Munduba. Tais cuidados são necessários em decorrência do acúmulo histórico de contaminantes em certas zonas de sedimentação do estuário (CETESB, 2004). Há mais ou menos três anos atrás foram removidos cerca de três milhões de metros cúbicos de material sedimentado misturado a produtos químicos (alguns deles cancerígenos, segundo a CETESB) depositados no fundo do estuário desde a década de 60, localizado desde o Porto da COSIPA até o início do canal do Porto de Santos.

Estudos realizados na área concluíram que a ocorrência de substâncias químicas já não tem sido detectada com freqüência na água, mas principalmente no sedimento e nos organismos que vivem no canal (CETESB, 2001b). Os poluentes indicados pelas avaliações da CETESB vão desde elementos traço que não se dissolvem na água e permanecem depositados nos sedimentos (chumbo, cádmio, zinco, crómio, mercúrio, níquel) até resíduos de ascarel, solventes aromáticos, pesticidas organoclorados e compostos fenólicos, além de muito óleo e graxa.

$\mathrm{Na}$ Espanha, as ameaças de impactos ambientais aos ecossistemas costeiros, não são muito diferentes. A Galícia é uma das Comunidades Autônomas com maior extensão de costa e desde o ponto de vista geomorfológico, um dos litorais mais complexos da Península Ibérica, onde as Rías, denominação local utilizada para extensas reentrâncias de até $20 \mathrm{~km}$ de extensão por 1 a $5 \mathrm{~km}$ de largura, são sua característica mais peculiar. No fundo das Rías se dá o encontro das águas fluviais com as do mar constituindo um ambiente estuarino e de planícies de maré denominado Marisma, com características similares, sob o ponto de vista geomorfológico, estratigráfico e geoquímico, aos dos 
manguezais tropicais. Algumas destas áreas apresentam um bom estado de conservação, entretanto, as atividades industriais, mineiras e principalmente portuárias têm contribuído para a contaminação ambiental destas áreas costeiras. Ao longo dos 1.195 $\mathrm{km}$ da costa Galega, está instalado um corredor marítimo que fica a apenas 3,7 quilômetros do litoral com trânsito constante e intenso de navios, que em muitas vezes apresentam-se como verdadeiras bombas ecológicas. Exemplos disso foram os impactos causados pelos acidentes com os navios petroleiros Mar Egeu no ano de 1992 e o Prestige em 2002. Neste último e maior já ocorrido na Espanha, cerca de $11 \mathrm{mil}$ toneladas de óleo foram despejadas no mar. As correntes marítimas e o vento se encarregaram de levar a pegajosa camada negra até a costa.

Uma vez que a acumulação destes elementos traço em sistemas estuarinos é um processo que depende basicamente de alterações nos estados de oxi-redução na interface água-solo, fatores que alterem as condições biogeoquímicas do solo alterarão em última análise as taxas de acumulação de elementos traço nos solos destes ambientes. Portanto, para compreender o papel dos manguezais e das marismas na ciclagem dos elementos traço em sistemas estuarinos é fundamental estudar-se o comportamento e distribuição dos mesmos nestes ambientes e o efeito de processos biogeoquímicos sobre a química dos solos e sua água intersticial.

Visto o exposto e considerando que dentre os diferentes fatores capazes de alterar os processos biogeoquímicos em solos de manguezais e marismas encontram-se: a amplitude e freqüência de inundação pelas marés; a composição geoquímica dos sedimentos (Chiu \& Chou, 1991); a carga e origem do material particulado em suspensão (Lacerda et al., 1988); e a própria atividade biológica, como o tipo de vegetação e sua atividade radicular sobre o sedimento (Otero et al., 2000 a, b; Otero \& Macías, 2001; 2002 a, b), o presente estudo foi proposto com o objetivo principal de estabelecer o comportamento geoquímico de diversos elementos traço relacionado à geoquímica do Fe e $\mathrm{S}$ em solos de sistemas estuarinos de clima tropical (manguezais) e de sistemas estuarinos de clima temperado (marismas) com diferentes graus e tipos de contaminação, com base nas hipóteses de que, nos solos com ambientes óxicos a subóxicos, os oxihidróxidos de ferro são as formas dominantes enquanto que nos 
anóxicos é o ferro pirítico e que, os elementos traço nos solos de ambientes anóxicos estão incorporados preferencialmente à pirita. E também, de verificar os níveis de base dos elementos traço nos solos dos manguezais e das marismas, baseado na hipótese de que as áreas sob a influência de atividades industriais e urbanas podem apresentar concentrações desses elementos com caráter antrópico a níveis tóxicos, ao passo que a área livre de impactos antrópicos deverá apresentar apenas os de origem natural. 


\section{REVISÃO DE LITERATURA}

\subsection{Caracterização do ecossistema de manguezal}

O manguezal consiste num sistema ecológico costeiro tropical, dominado por espécies vegetais típicas, às quais se associam outros componentes da flora e da fauna, microscópicos e macroscópicos, adaptados a um substrato periodicamente inundado pelas marés, com grandes variações de salinidade (Aciesp, 1987; Schaeffer-Novelli, 1999). São geralmente sistemas jovens que, seguindo a dinâmica das marés nas áreas onde se localizam, produzem modificação na topografia desses terrenos, resultando numa seqüência de recuos e avanços da cobertura vegetal. São sistemas funcionalmente complexos, altamente resistentes e, portanto, relativamente estáveis. A cobertura vegetal se instala em substratos de vasa (argiloso e lamacento) de formação recente e de pequena declividade, sob a ação diária das marés de água salgada ou, salobra (SchaefferNovelli, 1999).

Baseado em Walsh (1974), a ocorrência dos manguezais está associada a cinco condicionantes básicos: temperaturas tropicais, com média de temperatura dos meses mais frios superior a $20^{\circ} \mathrm{C}$; substrato aluvial, onde predominem materiais finos (silte, argila) e matéria orgânica; áreas de baixa energia, caracterizadas pela ausência de ventos fortes e marés violentas; presença de água salgada, uma vez que por serem as espécies de mangue "halófitas facultativas", suportam teores de sal que impedem o desenvolvimento de plantas de hábito terrestre; grande amplitude de maré, que associada a uma reduzida declividade do terreno, permite a colonização de extensas áreas por espécies de mangue adaptada às altas taxas de salinidade desses ambientes.

Os manguezais encontram-se distribuídos ao longo de praticamente todo litoral. O Brasil é um país privilegiado pela existência dos manguezais, que se estendem desde o 
extremo norte, no Macapá, até o sul de Santa Catarina, na foz do Rio Araranguá. Localizados entre os níveis mais altos e mais baixos das marés, tornando-se verdadeiras áreas de transição entre ambientes terrestre, marinho e de água doce (Aquino, 1987).

Segundo levantamentos feitos pelo Grupo de Estudos de Ambientes de Manguezal (GEAM), estima-se que o território brasileiro possui uma das maiores áreas de manguezal do mundo, aproximadamente $20.000 \mathrm{~km}^{2}$ de extensão, distribuindo-se desde o Cabo Orange, na fronteira com a Guiana Francesa até Laguna, no Estado de Santa Catarina.

A região da Baixada Santista formada pelos municípios de Bertioga, Cubatão, Guarujá, Itanhaém, Mongaguá, Praia Grande, Santos, e São Vicente possui uma área total de cobertura vegetal de $1.716,6 \mathrm{~km}^{2}$ sendo que desta área $105,06 \mathrm{~km}^{2}$ correspondem às áreas de mangue (SMA, 2001). Os manguezais do sistema Cananéia Iguape ocupam praticamente todas as margens do sistema, compreendendo uma área de aproximadamente $72 \mathrm{Km}^{2}$ (Hers, 1991).

\subsubsection{Solos de manguezal}

Os solos de manguezais, definidos em muitos trabalhos como "solos indiscriminados de mangue" são solos desenvolvidos a partir de sedimentos marinhos e fluviais com presença de matéria orgânica e ocorre em regiões de topografia plana na faixa costeira sob a influência constante do mar (EMBRAPA, 1978).

A inundação desses solos é dominada pelo fluxo e refluxo das marés que traz materiais em suspensão e possibilidade de deposição de contaminantes ambientais. Durante este processo, as águas da maré interagem com o emaranhado de raízes aéreas típicas deste ecossistema, resultando uma diminuição da capacidade de transporte de sedimentos e na acumulação destes dentro da floresta, de tal forma, que a maior parte dos manguezais apresenta taxas de acumulação de sedimentos da ordem de 0,1 a 0,2 cm.ano ${ }^{-1}$ (Smoak \& Patchineelam, 1999).

De acordo com Cintrón \& Schaeffer-Novelli (1983), os solos desses ecossistemas, por estarem em ambiente de baixa energia, apresentam predominância das 
frações mais fina (argila e silte), elevadas quantidades de matéria orgânica e sais solúveis em função do contato com o mar. Devido à decomposição da serapilheira e à saturação pela água, são solos reduzidos de cores acinzentadas a pretas nas camadas superficiais com presença de $\mathrm{H}_{2} \mathrm{~S}$. Podem ter vários metros de profundidade sendo fracamente consolidados e semi-fluídos.

Em trabalho realizado no Vale do Ribeira (SP) Lepsch et al. (1998), indicaram que os solos de manguezais estão situados em áreas de difícil penetração correspondendo em sua maior parte aos Gleissolos tiomórficos e Gleissolos sálicos segundo o Sistema Brasileiro de Classificação de Solos da Embrapa (1999).

Prada-Gamero (2001), classificou os solos do manguezal do Rio Irirí (BertiogaSP), como Organossolo tiomórfico e Gleyssolo tiomórfico em função da posição fisiográfica. Do mesmo modo, Ferreira (2002), encontrou solos também correspondentes aos Organossolo tiomórfico e Gleyssolo tiomórfico no manguezal do Rio Crumahú (Guarujá-SP), conforme· o Sistema Brasileiro de Classificação de Solos (EMBRAPA, 1999).

A inundação a que são frequentemente submetidos os solos de manguezais é responsável por importantes alterações físico-químicas nestes solos. Alterações estas que causam a queda do potencial redox, o aumento dos valores de $\mathrm{pH}$, mudanças no equilíbrio de minerais e na dinâmica de elementos como o ferro e o enxofre (Ponnamperuma, 1972).

Estes solos apresentam ampla variação nos valores de $\mathrm{pH}, \mathrm{CTC}$, teor de matéria orgânica, capacidade de retenção de água, potencial redox, salinidade, nitrogênio e fósforo extraível (Cardona \& Botero, 1998). Também apresentam variada composição mineralógica. Nos solos de manguezais podem ser encontrados minerais como quartzo, halita e jarosita (Marius \&. Lucas, 1991), mas os minerais encontrados com maior freqüência são montmorilonita, caulinita, ilita e clorita (Prakasa \& Swamy, 1987). Entretanto, a combinação de elevados conteúdos de matéria orgânica (5 a 15 \%) e enxofre, em condição anaeróbica, as fontes de ferro reativo e as fontes de sulfato prontamente disponíveis, fazem dos solos de manguezais um ambiente propicio a 
ocorrência da redução bacteriana do sulfato a sulfeto e seu conseqüente acúmulo sob a forma de pirita $\left(\mathrm{FeS}_{2}\right)$ (Breemen \& Buurman, 1998). Este processo conhecido por piritização pode ou não passar por etapas onde ocorra a förmação de sulfetos de ferro menos estáveis (precursores da pirita), como a greigita e mackinawita, conhecidos por sulfetos voláteis em meio ácido (AVS). Nestes solos, a diversidade de argilominerais encontrada, ocorre em função da origem mineralógica. Os alóctones (caulinitas, micas e esmectitas) são representados por minerais desenvolvidos na plataforma continental e os autóctones (micas, esmectitas e piritas), são representados por minerais desenvolvidos em ambientes concentrados, halomórficos, e frequentemente saturados com água, hidromórficos (Prada-Gamero et al., 2004). Outros minerais, como a glauconita (mica dioctaedral com $\mathrm{Fe}^{2+}$ e $\mathrm{Fe}^{3+}$ nas posições octaedrais) também podem se formar em função das condições geoquímicas presentes nestes ambientes (Fanning et al., 1989; Prada-Gamero et al, 2004).

\subsubsection{Vegetação de mangue}

Sugiyama (1995) sugere que o termo "manguezal" está relacionado à comunidade do ponto vista ecológico-fisionômico, enquanto "mangue" refere-se apenas às espécies vegetais.

Assim sendo, o manguezal, banhado por água salobra ou salgada, tem sua comunidade vegetal adaptada às condições especiais e peculiares do ambiente, condicionando a sobrevivência de apenas algumas poucas espécies. Essas espécies possuem adaptações que lhes permitem extrair água doce da água do mar, excretar o excesso de sal pelas folhas, realizarem trocas gasosas através de estruturas (lenticelas) localizadas nas raízes-escora e nos pneumatóforos, sustentação sobre sedimentos pouco consolidados por meio de complexo sistema radicular e ainda, se reproduzirem por propagação vegetativa, utilizando propágulos diásporos, ou seja, que se dispersam por via aquática (Schaeffer-Novelli, 1991). 


\subsubsection{Principais espécies de mangue}

As espécies de vegetais superiores constituintes das florestas de mangue podem ser classificadas em obrigatórias ou principais e, facultativas ou secundárias. $\mathrm{Na}$ primeira categoria encontram-se sete espécies pertencentes a quatro gêneros, Rhizophora, Avicennia, Laguncularia e Conocarpus. Como facultativas são incluídas as espécies Hibiscus tiliaceus, Acrostichum aureum, Spartina brasiliensis e Spartina alterniflora (Schaeffer-Novelli, 1991).

No Brasil, dentre as classificadas como obrigatórias, a flora típica de mangue apresenta três espécies principais, verdadeiramente adaptadas para as condições de salinidade e aeração dos solos característicos dos manguezais: Rhizophora mangle, Avicennia schaueriana e Laguncularia racemosa (Lamberti, 1966; Por, 1994; SchaefferNovelii, 1995).

\section{Rhizophora mangle}

A espécie Rhizophora mangle é a mais popular, sendo conhecida como manguevermelho. De hábito arbóreo com copa arredondada, esta espécie pode atingir $12 \mathrm{~m}$ de altura ou mais. As plântulas desta espécie se desprendem da planta mãe, caem no solo e enraízam-se em condições favoráveis. Um dos aspectos de maior destaque desta espécie está em seu sistema radicular em forma de arco. As chamadas raízes de escora apresentam características bastante peculiares como, por exemplo, interior esponjoso e presença de lenticelas que permitem a troca de $\mathrm{O}_{2}$ e $\mathrm{CO}_{2}$ entre a planta e o meio no momento da inundação pelas marés. Partindo diretamente do tronco e do caule da árvore, estas raízes promovem a sustentação e a troca gasosa com a atmosfera.

\section{Avicennia schaueriana}

Esta árvore apresenta porte semelhante ao da $R$. mangle, sendo conhecida vulgarmente como mangue siriúba. Seus frutos em forma de cápsula oval achatada e a presença de um sistema radicular dotado de pneumatóforos garantem a propagação e a sobrevivência da espécie. Seu sistema radicular desenvolve-se horizontalmente, a 
poucos centímetros abaixo da superfície do solo. Os pneumatóforos consistem em ramificações das raízes axiais que crescem eretas expondo-se ao ar e permitem, através da ação de lenticelas, o armazenamento de ar e a conseqüente aeração do sistema radicular.

\section{Laguncularia racemosa}

Laguncularia racemosa é uma árvore que difere das outras por apresentar um menor porte aproximadamente $6 \mathrm{~m}$ de altura podendo, às vezes, aparentar hábito arbustivo. Esta espécie é conhecida vulgarmente como mangue rasteiro ou canapomba. Suas folhas têm duas glândulas para eliminação de sal junto ao pecíolo, nas bases da lâmina foliar. Quanto ao sistema radicular, é semelhante ao da Avicennia, também apresenta pneumatóforos, porém de formato menores e bifurcados ou trifurcados.

\section{Hibiscus tiliaceus}

Conhecido vulgarmente como algodoeiro da praia, é um arbusto de inúmeras ramificações e bastante comum na arborização de cidades litorâneas. Suas folhas e flores são grandes e suas raízes apresentam um caráter adventício bastante ramificado, fino e de pouca penetração no solo.

\section{Acrostichum aureum}

A denominada samambaia do mangue consiste em uma erva terrestre com caule ramificado e folhas compostas em forma de penas. $\mathrm{O}$ sistema radicular $=-{ }^{-}$-superficial e também constituído por raízes adventícias.

\subsubsection{Relação solo - vegetação}

\section{Mangue Vermelho (Gênero Rhizophora)}

Desenvolvem-se melhor em solos siltosos rasos, inundados por água salobra e protegidos da ação direta das ondas e do oceano, mas que estejam em locais com 
abundância de água natural e elevados índices de pluviosidade. Os solos que sustentam este tipo de mangue normalmente apresentam valores de $\mathrm{pH}$ elevados, relação $\mathrm{C} / \mathrm{N}$ alta $\mathrm{e}$ elevados teores de enxofre oxidável, nitrogênio, fósforo e carbono. Ocupam geralmente as margens dos rios e suas planícies de inundação onde o aporte de nutrientes é elevado (Jimenez, 1985).

\section{Mangue Branco (Gênero Laguncularia)}

Consegue se desenvolver bem nos mais diversos tipos de solos, desde arenosos a argilosos. Estes devem, porém, se encontrar com presença de água salobra e posição elevada ou interna onde a freqüência e a intensidade das marés são menores. Por ser uma planta que possui um sistema de excreção para sua regulação salina, o mangue branco é capaz de suportar os mais diversos níveis de salinidade (Jimenez, 1988).

\section{Mangue Negro (Gênero Avicennia)}

Assim como para os outros tipos de mangue, a presença de água salobra é necessária para seu desenvolvimento com a diferença de se adaptar melhor a ambientes mais secos e com menor freqüência de inundações. A exemplo do mangue branco se desenvolve em solos de diversas texturas e salinidade, fazendo uso de seu sistema de excreção de sais. É bastante encontrado em solos que apresentam elevada concentração de pirita. (Jimenez \& Lugo, 1988).

\section{Samambaia do mangue (Acrostichum) e Algodoeiro da praia (Hybiscus)}

Estes dois outros componentes da flora do mangue costumam ser encontrados em ambientes de transição entre manguezal e terra firme, assim como em locais onde há algum tipo de influência ou impacto antrópico. Ambos têm ocorrência comum em solos mais firmes que sofrem menor influência da água do mar (Sugiyama, 1995). 


\subsection{Caracterização do ecossistema de marisma}

As marismas são ecossistemas correspondentes aos manguezais e ocorrem em regiões com variação de clima subtropical a frio, onde as espécies de mangue não conseguem sobreviver. Assim como os manguezais, estão incluídas dentro dos ecossistemas mais produtivos do mundo, apresentando grande importância tanto ecológica como econômica. Desempenham, através de suas altas taxas de produção primária, um importante papel na cadeia trófica dos sistemas estuarinos e mares adjacentes, controlando a qualidade ambiental (De Laune \& Gambrell, 1996).

As marismas são tidas como grande provedora de matéria orgânica vegetal para teias alimentares estuarinas e costeiras, sendo esta predominantemente utilizada sob a forma de detrito enriquecido por biomassa bacteriana. São utilizadas como áreas de refúgio para acasalamento, berçário, moradia e fonte de alimento por várias espécies de aves residentes e migratórias, incluindo ainda pequenos roedores, répteis, peixes e crustáceos (Panitz, 1992; Peixoto, 1997).

Alguns autores definem as marismas como um sistema natural ou seminatural formado a partir de sedimentos aluviais, colonizados por vegetação herbácea ou de porte arbustivo halofítica que se encontra rodeado por água salgada e submetida a inundações periódicas pela ação dos movimentos das marés. Neste sentido, apesar das marismas estarem submetidas a uma inundação periódica como conseqüência do fluxo das marés, a ação ou influência destas não é homogênea o que confere a existência de diferentes tipos de marismas (Long \& Mason, 1983).

No Brasil as marismas ocorrem no litoral da região sul, onde a Lagoa dos Patos (RS) é o principal expoente desse ecossistema.

\subsubsection{Fisiografia da marisma}

A costa Galega apresenta dois tipos de Marismas: Marisma alta e Marisma baixa (Otero \& Macias, 2001). 
A marisma baixa se inunda todos os dias duas vezes devido a sua elevação ser inferior ao nível médio das preamares mortas, enquanto que a marisma alta fica totalmente coberta pelo manto mareal apenas nos períodos de marés vivas.

$\mathrm{Na}$ marisma alta existe um importante número de formas de terreno que podem condicionar significativamente o período de alagamento de uma determinada superfície. Dentre as principais formas fisiográficas de uma marisma, com base no trabalho de Long \& Mason (1983) temos:

\section{Canais de drenagem das marés}

É uma das feições morfológicas mais evidentes da marisma alta. Apresentam-se formando um denso reticulado de largura e profundidade muito variável podendo alcançar $3 \mathrm{~m}$ de profundidade e largura superior a $5 \mathrm{~m}$. Sua formação não está bem estabelecida e pode estar associada à própria dinâmica de crescimento da marisma, que se vê acelerada pela colonização das plantas. Nas áreas ocupadas pelas plantas a deposição de sedimento é favorecida, incrementando com mais rapidez sua elevação quando comparada com as áreas não colonizadas. Estas últimas são as que acabam transformando-se nos canais, o fluxo e refluxo das marés impedem sua colonização posterior e permite sua permanência com o tempo. Os solos associados aos fundos de canais se encontram fortemente reduzidos, já que são os primeiros a serem inundados com a preamar e os últimos que ficam expostos ao ar durante a baixamar.

\section{Borda de canal}

Costumam apresentarem-se como ligeiras elevações referentes ao entorno e nas marismas do Norte da Península, se caracterizam por estar ocupados pela espécie Halimione Portulacoides (Sánchez, 1995), o qual parece indicar que se trata de solos com potencial redox mais elevado que do resto do entorno. Neste sentido, Sánchez et al. (1998), verificaram que as condições redox destes solos estão acima do limite a partir do qual se inicia a redução dos oxihidróxidos de $\mathrm{Mn}(\sim 200 \mathrm{mV})$, o qual está de acordo com a sensibilidade das plantas dicotiledôneas a toxicidade por $\mathrm{Mn}^{2+}$ (Singer \& Havill, 
1993). A maior aeração destes solos pode estar relacionada com a maior condutividade hidráulica que permite uma rápida drenagem (Price et al., 1988).

\section{Planície de marisma}

Ocupa a maior parte das marismas altas e baixas apresentando um perfil plano que facilita a drenagem superficial. A maior parte da planície das marismas altas se encontra ocupada por diferentes associações de junco (Juncus maritimus) e em pequenas depressões com solos alagados permanentemente aparece a Spartina maritima.

\section{Cubetas hipersalinas}

Correspondem a depressões intercaladas na planície da marisma que não se encontram colonizadas por plantas vasculares. Sua formação pode ocorrer de diferentes maneiras. Uma das possíveis explicações é similar à utilizada para explicar a origem dos canais de drenagem. Inicialmente a superfície da marisma baixa é irregular, de modo que quando se produzem as primeiras fases de colonização vegetal, as plantas ocupam as áreas mais elevadas. Estas tendem a evitar as pequenas depressões que representam um meio mais hostil por seu prolongado período de inundação. Desta maneira, aos poucos, as depressões ficam imersas em um entorno colonizado por plantas, que rapidamente aumenta sua elevação devido à retenção e deposição do sedimento ser maior, formando assim as cubetas. Outros autores estabelecem que as cubetas possam ser antigos canais de drenagem que, por deslizamento de suas paredes, ficaram aterrados. As cubetas permanecem sem serem colonizadas pela vegetação uma vez que apresentam condições extremas devido a permanente inundação e/ou excessiva salinidade.

\subsubsection{Solos de marisma}

As marismas são ambientes sedimentares, invadidos periodicamente durante a maré alta e associados diretamente à existência de estuários, na área de contato de águas marinhas e fluviais, onde se produzem uma grande acumulação de sedimentos, 
fundamentalmente, silte, argila e areia, que acabam emergindo acima do nível da maré alta.

Os solos presentes nas marismas litorais se caracterizam por apresentar períodos prolongados de encharcamento devido principalmente aos efeitos das marés. Do ponto de vista fisiográfico tradicionalmente se diferenciaram dois tipos de ambientes: Sapropel e Marsh. O primeiro corresponde à marisma baixa, sem cobertura vegetal. O Marsh é característico da marisma alta, com cobertura vegetal bem desenvolvida (Leiros de la Peña \& Guitián, 1981).

O tempo que o solo permanece inundado varia de acordo com o tipo de marisma, alta ou baixa. Estudos realizados nas marismas inglesas mostraram que enquanto a marisma baixa ficava totalmente inundada durante 2600 horas $a^{-1}$, a marisma alta ficava apenas 450 horas.ano $^{-1}$ (Long \& Mason, 1983). Esta variação no tempo de inundação confere ao solo propriedades e processos diferentes, dentre os quais os mais interessantes são os processos de redução. Em solos bem aerados, a oxidação da matéria orgânica ocorre através dos microrganismos aeróbios que utilizam como receptor de elétrons o oxigênio. Quando o solo está inundado, a difusão do oxigênio é inibida de modo que os microrganismos passam a utilizar como receptor de elétrons outros compostos ou elementos. Depois dos nitratos (pouco abundantes em água marinha) são utilizados os óxidos de manganês e ferro, originando $\mathrm{Mn}^{2+}$ e $\mathrm{Fe}^{2+}$ que são mais solúveis que as formas oxidadas. Se o período de inundação é muito prolongado, pode acontecer das formas mais lábeis de óxidos de $\mathrm{Fe}$ e $\mathrm{Mn}$ se esgotarem, passando então a sulfato redução, isto é, o sulfato presente na água do mar é utilizado pelas bactérias para oxidar a matéria orgânica. Assim, nas marismas temos solos óxicos, situados na parte mais elevada da marisma alta, subóxicos (onde o Mn e o Fe podem sem encontrados na forma reduzida) e anóxicos (onde se produz a sulfato redução). A combinação das condições de salinidade e processos de oxidação-redução explica de maneira satisfatória a distribuição da maior parte das comunidades vegetais neste ecossistema.

A composição e propriedades dos solos também apresentam uma ampla faixa de variação. No general, são solos onde predominam as frações finas (silte e argila), com 
alto conteúdo de $\mathrm{C}$ orgânico que oscila entre 3-10\% mas que em determinadas situações pode alcançar valores superiores a $20 \%$. Os horizontes e propriedades de diagnóstico mais freqüentes são a presença de um horizonte superficial A ócrico ou úmbrico, mais raramente, um $\mathrm{H}$ hístico. As condições sálicas e oleicas aparecem em todo o perfil. Nos solos com condições anóxicas em profundidade (normalmente colonizados por Spartina maritima) se produz a acumulação de formas reduzidas de enxofre (principalmente pirita, $\mathrm{FeS}_{2}$ ), dando lugar à presença de material sulfúrico. Os solos encontrados com maior freqüência são os Fluvissolos tiônicos, Fluvissolos sálicos e Histosol tiônico (Otero-Perez, 2000). A presença do material sulfúrico confere a estes ambientes uma especial sensibilidade, pois quando o solo é drenado ou extraído e exposto a condições oxidantes, a pirita assim como outros sulfetos metálicos presentes no solo são oxidados, gerando ácido sulfúrico o qual pode produzir grave impacto ambiental. Quando isto ocorre tem origem os denominados solos ácido-sulfatados.

Os estudos realizados na Galícia sobre solos̉ de marismas indicaram a presença de Halic Sulfaquents, Typic Sulfaquents e Sulfic Hydraquents segundo Bescansa \& Roquero (1990), enquanto que Leiros de la Peña \& Guitian (1981) encontraram Fluvisol dístrico em área de sapropel e em Marsh, Fluvissolos eutricos e calcários.

Sánchez (1995) descreveu os solos da marisma de Mera (Ría de Ortigueira), em marisma alta (Marsh) como Fluvissolos tiônicos e sálicos. Estudando a mesma área Otero-Perez (2000) descreveu os solos como Typic Sulfaquents, Histic Sulfaquents e Sodic Hidraquents, em função da posição geográfica.

\subsubsection{Vegetação de marisma}

A vegetação das marismas responde as características físico-químicas do substrato, submetida a alagamentos periódicos e oscilações das marés.

A influência das marés determina a instalação de uma vegetação muito característica e especializada que aparece em conjuntos segundo sua tolerância a permanecer submersa. Assim, no nível mais baixo, sobre um substrato fraco e pouco sólido, encontram-se apenas algas verdes, que suportam bem aos longos períodos 
cobertos pelas marés. Nas superfícies que são inundadas por marés de amplitude média, aparecem as gramíneas, que com suas raízes fixam e elevam o substrato, o que permite $o$ assentamento de outras plantas menos preparadas para fazer frente às marés. Sobre esse substrato mais elevado aparece uma terceira franja vegetal formada por plantas tipicamente marinhas, que ocupam áreas bastante úmidas, ricas em sais e aporte de nutrientes de origem terrestre.

As plantas que conseguem colonizar este tipo de ambiente apresentam adaptações especiais para sobreviver na presença das limitações oferecidas por este meio. No geral, a salinidade é considerada como um dos principais limitantes no desenvolvimento vegetal, entretanto existem trabalhos que apontam também, as condições de oxidação-redução do solo como uma variável importante que afeta a distribuição das comunidades vegetais nas marismas (Long \& Mason, 1983).

$\mathrm{Na}$ Galícia, as espécies comuns neste ambiente são Spartina marítima, Halimeone portulacoides, Juncetum maritimi e Limonio serotini (Otero \& Macias, 2001). No Brasil encontram-se Spartina densiflora, Spartina alterniflora, Scirpus maritimus, Scirpus olneyi e Juncus effurus (Peixoto \& Costa, no prelo).

\subsection{Processos redox em solos de sistemas estuarinos}

A inundação periódica dos solos das marismas, assim como em solos de manguezais, faz com que estes se encontrem saturados de água tanto em superfície como em profundidade. Quando isto ocorre, mudanças importantes são produzidas com respeito aos processos químicos e biológicos que caracterizam um solo bem drenado e aerado. A causa inicial destas mudanças é a diminuição ou desaparecimento do oxigênio devido à dificuldade que a água oferece para sua difusão (Greenwood, 1961).

Nos manguezais e marismas a grande produção de serapilheira resulta em elevadas concentrações de matéria orgânica nos solos. A sedimentação intensa de partículas finas, o acúmulo de matéria orgânica e alta freqüência de inundação resultam no rápido consumo do oxigênio presente nas águas intersticiais dos solos. Quando os solos são submersos, durante a maré cheia, o suprimento de oxigênio é drasticamente 
reduzido, devido à difusão do ar num meio aquoso diminuir na ordem de 10.000 vezes em relação a um meio gasoso (Greenwood, 1961). Assim, em poucas horas (18-36 h) de submersão, pode chegar à zero (Turner \& Patrick, 1968). Os microrganismos aeróbicos presentes no solo utilizam todo o oxigênio disponível tornam-se quiescentes ou morrem. Uma vez que o oxigênio desaparece ou sua concentração se reduz a níveis inferiores a 4 $\%$ (Eh $330 \mathrm{mV}$ a pH 7), os microrganismos passam a usar outros oxidantes presentes no solo, os quais são utilizados de maneira seqüencial obedecendo a seguinte ordem: nitratos, óxidos e hidróxidos de $\mathrm{Mn}$ e $\mathrm{Fe}$, sulfato e $\mathrm{CO}_{2}$ (Turner \& Patrick, 1968; Ponnamperuma, 1972). Quando a oxidação ocorre em condições anaeróbias o $\mathrm{NO}_{3}{ }^{-}$atua como receptor de elétrons e o produto final podem ser tanto o $\mathrm{S}$ elementar como também o sulfato (Ehrlich, 1996). O sulfato é reduzido a sulfeto uma vez que o $\mathrm{NO}_{3}{ }^{-}$e as formas mais biodisponíveis de $\mathrm{Mn}^{4+} \mathrm{e} \mathrm{Fe}^{3+}$ são esgotadas ou se fazem muito escassas.

\section{Redução do nitrato}

Quando os poros do solo se encontram ocupados por água, a troca gasosa é restringida e a difusão do oxigênio fica limitada a poucos centímetros da parte superficial do solo. Não obstante, a profundidade do horizonte superficial oxidado pode oscilar notavelmente de uns poucos milímetros a vários centímetros, devido principalmente ao efeito da bioperturbação e a demanda de oxigênio interna do sistema, que depende da quantidade e qualidade da matéria orgânica (Howeler, 1992, Gambrell \& Patrick, 1978). Enquanto o oxigênio desaparece ou se reduz abaixo de $4 \%$, começa o uso do nitrato como oxidante da matéria orgânica (Reddy et al., 1986). A redução do nitrato pode gerar vários produtos sendo os principais o nitrogênio molecular $\left(\mathrm{N}_{2}\right)$ ou também o óxido nitroso $\left(\mathrm{N}_{2} \mathrm{O}\right)$. Em ambos os casos o processo é denominado desnitrificação, devido à perda deste elemento do solo (Ponnamperuma, 1972). A desnitrificação é realizada por microrganismos aeróbios facultativos e ocorre a valores de Eh que oscilam entre 200 e $300 \mathrm{mV}$ (Turner \& Patrick, 1968). O nitrogênio pode também ser reduzido a $\mathrm{NH}_{4}{ }^{+}$, entretanto este processo é realizado por microrganismos 
anaeróbios estritos (Clostridium) e requerem condições mais reduzidas (Caskey \& Tiedje, 1980).

O rendimento energético da oxidação da matéria orgânica pelo nitrato é elevado e similar ao que se obtém por meio do oxigênio, motivo pelo qual existem vários grupos de bactérias e fungos que usam os nitratos como receptor final de elétrons. A principal limitação para este tipo de respiração nos solos de manguezais e marismas é que o nitrato resulta em um recurso escasso, devido a sua reduzida concentração da água do mar (Reddy et al., 1986).

\section{Redução de oxihidróxidos de manganês}

Se a concentração do nitrato se torna escassa e se mantém a demanda de receptores de elétrons, os microrganismos anaeróbios facultativos podem utilizar os oxihidróxidos de Mn durante sua atividade metabólica. O potencial redox que os solos alcançam ao atingir neste momento é relativamente alto $(\sim 200 \mathrm{mV})$, e sua eficácia energética é $67 \%$ da obtida com o oxigênio (Reddy et al., 1986).

Os compostos de manganês mais freqüentes presentes em sedimentos apresentam formas de $\mathrm{Mn}(\mathrm{IV})$ de baixa cristalinidade e se encontram como recobrimentos de outras partículas do solo. O produto final da redução do $\mathrm{Mn}(\mathrm{IV})$ é principalmente o $\mathrm{Mn}^{2+}$, ainda que o $\mathrm{Mn}^{3+}$ também possa ser produzido tanto por processos de redução como de oxidação (Burdige, 1993). $\mathrm{O} \mathrm{Mn^{2+ }}$ passa inicialmente a formar parte da água intersticial bem como íon livre ou complexado a compostos orgânicos (Ederfield, 1981). Em ambientes anóxicos com alta alcalinidade, sua solubilidade está controlada principalmente por carbonatos podendo formar precipitados (Mucci, 1988). Em meios anóxicos com presença de sulfetos, $\mathrm{o} \mathrm{Mn}^{2+}$ pode precipitar como sulfetos de Mn (Suess, 1979). Também, uma parte deste manganês pode difundir até áreas mais elevadas do perfil e oxidar-se novamente. De acordo com Caetano et al. (1997), a cinética da oxidação do $\mathrm{Mn}^{2+}$ em solos de manguezais e marismas é relativamente lenta, tendendo a sair do perfil na forma iônica, ao contrário do $\mathrm{Fe}^{2+}$ que geralmente precipita na parte superior do solo. 


\section{Redução de oxihidróxidos de ferro}

Esgotados os oxihidróxidos de Mn, inicia-se a redução dos oxihidróxidos de $\mathrm{Fe}$, fazendo com que o solo atinja um Eh próximo aos $100 \mathrm{mV}$. Trata-se de um processo importante por supor uma das principais formas de mobilização do ferro, o qual é um componente fundamental do solo. A redução dos oxihidróxidos de $\mathrm{Fe}$, a diferença de $\mathrm{NO}_{3}{ }^{-}$e o $\mathrm{Mn}$, supõem uma mudança significativa na cor do solo que varia dependendo da forma mineral mais abundante. Assim, os solos bem aerados apresentam cores avermelhadas, laranjas etc., dependendo tanto do tipo de oxihidróxidos de Fe como da quantidade de matéria orgânica presente, enquanto que os solos ou horizontes onde o $\mathrm{Fe}$ está em sua forma reduzida apresentam mosqueados avermelhados ou cinzas (hidromorfia alternante) ou um matiz esverdeado ou acinzentado (hidromorfia permanente).

$\mathrm{O}$ resultado da redução dos oxihidróxidos de $\mathrm{Fe}$ é principalmente a forma $\mathrm{Fe}^{2+}$, que inicialmente passa à água intersticial. $\mathrm{O} \mathrm{Fe}^{2+}$ pode difundir até a superfície e ser oxidado novamente ou ainda, precipitar como carbonato, fosfato ou sulfeto (mackinawita $\mathrm{FeS}$, pirita $\mathrm{FeS}_{2}$ ) dependendo das condições geoquímicas dos solos. Em qualquer dos casos, a maior parte de $\mathrm{Fe}^{2+}$ são novamente reoxidadas antes de serem isoladas definitivamente no solo ou sedimento (Canfield et al., 1993).

O rendimento energético do uso dos oxihidróxidos de Fe é muito inferior aos dos oxidantes anteriores. Quando acetato é utilizado como redutor e o $\mathrm{Fe}^{3+}$ (solúvel) como oxidante, o rendimento é de $-193,4 \mathrm{kcal}^{\mathrm{mol}}{ }^{-1}$, similar ao do oxigênio $\left(-201,8 \mathrm{kcal} \cdot \mathrm{mol}^{-1}\right)$, entretanto se o $\mathrm{Fe}(\mathrm{OH})_{3}$ é utilizado como oxidante, o resultado é bem inferior $\left(-5,5 \mathrm{kcal}^{\mathrm{mol}}{ }^{-1}\right)$. Estes resultados indicam que os microrganismos não são indiferentes ao tipo de oxihidróxidos de Fe(III) presente nos solos. Assim, Geobacter metallireducens é capaz de reduzir as formas amorfas de Fe, mas não as cristalinas (Lovely \& Phillips, 1986). As pronunciadas diferenças que existem entre os oxihidróxidos de Fe, relacionadas ao seu grau de cristalinidade e superfície específica, afetam de maneira importante a sua reatividade $e$ conseqüentemente a biodisponibilidade do Fe. Neste sentido, foi encontrada a seguinte ordem decrescente de 
solubilidade por parte da ação dos microrganismos $\mathrm{FePO}_{4} \cdot 4 \mathrm{H}_{2} \mathrm{O}>$ ferridrita $>\mathrm{Fe}(\mathrm{OH})_{3}>$ lepidrocrocita $\quad(\delta$-FeOOH $)>$ goethita $\quad(\alpha-\mathrm{FeOOH})$ (Postma, 1993). Por outro lado Postma \& Jacobsen (1996), verificaram que uma vez que as formas de $\mathrm{Fe}$ de baixa cristalinidade (principalmente lepidrocrocita ou ferridrita) são consumidas, começa os processos de sulfato redução.

\section{Sulfato redução}

Em solos anaeróbios o sulfato é reduzido a $\mathrm{HS}^{-}$uma vez que nitrato, e as formas mais disponíveis de $\mathrm{Mn}(\mathrm{IV})$ e $\mathrm{Fe}(\mathrm{III})$ são esgotadas ou se tornam muito escassas. A redução do sulfato é realizada por microrganismos anaeróbios restritos (Desulfovibrio, Desulfomonas e Desulfotomaculum) (Reddy et al., 1986). De acordo com Baas Becking \& Moore (1961), a redução microbiana do sulfato pode ocorrer em um amplo intervalo de $\mathrm{pH}(4,2$ a 10) e Eh (110 a -500 mV). Entretanto, os intervalos mais comuns se situam em valores de Eh que oscilam entre -75 e $-150 \mathrm{mV}$ e $\mathrm{pH}$ próximo da neutralidade (Connell \& Patrick, 1968).

Um fator que pode ser um limitante importante para as bactérias sulfato redutoras é a matéria orgânica, pois estas são capazes de utilizar apenas um reduzido número de substratos orgânicos, sendo os mais importantes os ácidos graxos de baixo peso molecular, álcoois, alguns ácidos orgânicos simples como o lático ou acético e $\mathrm{H}_{2}$ (Howarth \& Hoobie, 1982). Entretanto, está estabelecido que a redução do sulfato representa a principal forma de respiração microbiana nos solos de manguezais, marismas e zonas próximas à costa, podendo ultrapassar $90 \%$ da respiração total dos solos colonizados por Spartina alterniflora (Howarth, 1984).

Estas elevadas porcentagens são conseqüências do contínuo aporte de matéria orgânica lábil que recebem estes solos procedentes das plantas que se desenvolvem sobre eles, especialmente dos exudados das raízes. Também as bactérias fermentativas e fungos fazem um papel importante ao degradar os compostos orgânicos complexos a compostos orgânicos de baixo peso molecular (Howarth, 1984; Hines et al., 1989). Por outro lado, diferente dos oxidantes anteriores, o sulfato oferece duas vantagens: sua 
biodisponibilidade ao encontrar-se dissolvido na água intersticial e sua elevada concentração na água do mar ( 2700 mg.. $\left.\mathrm{L}^{-1}\right)$, sendo uma fonte quase inesgotável. O principal inconveniente é sua baixa eficiência energética, de maneira que a energia obtida utilizando o sulfato como receptor de elétrons é onze vezes menor que a obtida com o oxigênio (Reddy et al., 1986). Além disso, somente $25 \%$ da energia liberada pela oxidação da matéria orgânica tornam-se disponível para o crescimento dos microrganismos; enquanto que os $75 \%$ restantes ficam armazenados nas diferentes formas reduzidas de enxofre (pirita, enxofre elementar ou $\mathrm{H}_{2} \mathrm{~S}$ ) que atuam como fonte de energia para microrganismos quimioautótrofos e heterótrofos (bactérias e fungos) (Howarth, 1984; Ehrlich, 1996). A oxidação pode ocorrer tanto em meio anaeróbio como aeróbio dependendo da participação dos diferentes tipos de bactérias (geralmente eubactérias). Em condições de aerobiose o receptor de elétrons é o oxigênio, e o produto final da oxidação costuma ser o ácido sulfúrico como acontece com algumas espécies do gênero Thiobacillus (Th. thioparus, Th. ferrooxidans), Sulfolobus ou Acidiamus, originando os solos ácidos sulfatados. Quando a oxidação ocorre em condições anaeróbias, $\mathrm{o} \mathrm{NO}_{3}{ }^{-}$atua como receptor de elétrons e o produto final costumam ser o enxofre elementar ou também o sulfato (Ehrlich, 1996).

Os solos ácidos sulfatados são formados após a drenagem de materiais ricos em pirita $\left(\mathrm{FeS}_{2}\right)$. A pirita é formada em ambientes redutores com presença de matéria orgânica, $\mathrm{Fe}^{3+}$ e atividade de microrganismos. $\mathrm{O}$ enxofre provém da água do mar, que via de regra, periodicamente, encobre esses solos. As bactérias decompõem a matéria orgânica sob condições anaeróbicas, reduzindo os óxidos e hidróxidos de $\mathrm{Fe}^{3+}$ a Fe ${ }^{2+} \mathrm{e}$ íons sulfato a sulfeto e, levando a formação da pirita $\left(\mathrm{FeS}_{2}\right)$. Esta é estável sob condições anaeróbias, mas se oxida quando os solos são drenados. Como resultado, o ácido sulfúrico é formado segundo se indica nas reações 1 e 2 . Quando a quantidade de ácido produzida é maior que a capacidade de neutralização do solo produz-se uma acidificação dos solos e águas, podendo alcançar pH inferiores a 4,0 (Hart, 1959). 
$\mathrm{FeS}_{2}+7 / 2 \mathrm{O}_{2}+\mathrm{H}_{2} \mathrm{O} \quad \rightarrow \quad \mathrm{Fe}^{2+}+2 \mathrm{SO}_{4}{ }^{=}+2 \mathrm{H}^{+}$

Thiobacillus ferroxidans

$\mathrm{FeS}_{2}+14 \mathrm{Fe}^{3+}+8 \mathrm{H}_{2} \mathrm{O} \rightarrow 15 \mathrm{Fe}^{2+}+2 \mathrm{SO}_{4}{ }^{=}+16 \mathrm{H}^{+}$

Outro aspecto de extrema importância é a formação dos sulfetos metálicos e especialmente da pirita $\left(\mathrm{FeS}_{2}\right)$. A pirita é a forma reduzida do enxofre inorgânico mais abundante nos solos de marismas e manguezais, já que é o produto final dos processos de sulfato redução termodinamicamente mais estável (Bemer, 1984).

De acordo com Howarth (1979), as condições físico-químicas que estes solos apresentam parecem ser mais favoráveis na formação da pirita que em outros sulfetos de ferro como a mackinawita $(\mathrm{FeS})$ ou greigita $\left(\mathrm{Fe}_{3} \mathrm{~S}_{4}\right)$, a qual pode ocorrer em questões de horas. A pirita apresenta um produto de solubilidade (Kps: $2,4.10^{-28}$ ) muito inferior aos sulfetos de $\mathrm{Fe}$ mencionados (por exemplo mackinawita (Kps: 2,75.10 $0^{-18}$ )). Em experimentos realizados no laboratório, quando as concentrações de $\mathrm{H}_{2} \mathrm{~S}$ foram elevadas (pressão de $\mathrm{H}_{2} \mathrm{~S}=1$ atm. e $\mathrm{pH} 7,5$ ) se obteve como resultado final mackinawita (FeS), no entanto quando a concentração de $\mathrm{H}_{2} \mathrm{~S}$ foi reduzida (pressão de $\mathrm{H}_{2} \mathrm{~S}=10^{-4} \mathrm{~atm}$. e pH $7,5)$ se obteve unicamente pirita. Segundo este autor as condições físico-químicas dos solos das marismas e manguezais podem explicar o motivo pelo qual a pirita é o componente predominante nas espécies reduzidas de enxofre. Assim, o pH ligeiramente ácido destes solos $(5-6,5)$ supõe uma redução da atividade de $\mathrm{S}^{2-}$, com o qual a água intersticial se mantém insaturada para a mackinawita, mas não para a pirita. Além disso, a aeração parcial da parte superficial destes solos devido à bioperturbação dá lugar à formação de espécies de $\mathrm{S}$ parcialmente oxidadas como são os polisulfetos $\left(\mathrm{S}_{5}{ }^{2-}\right)$ que permitiria a rápida síntese da pirita sem ter como intermediário a mackinawita. No trabalho desenvolvido por Luther (1991), não se encontrou uma síntese direta e instantânea da pirita, e sim que esta passa pela formação prévia de uma forma metaestável de $\mathrm{S}$, concluindo que são necessários mais estudos relacionados à formação deste mineral em solos como os de marismas e manguezais. Por outro lado, a pirita está submetida a uma intensa reciclagem na parte mais superficial do sedimento, submetida a 
uma maior bioperturbação, que supõem sua contínua oxidação a oxihidróxidos de $\mathrm{Fe}$. O Fe(III) gerado posteriormente voltará a ser reduzido e piritizado. Neste sentido, Canfield et al. (1993), verificaram que um átomo de Fe pode ser oxidado e reduzido entre $100 \mathrm{e}$ 300 vezes antes de ser retirado definitivamente no solo.

As formas metaestáveis dos sulfetos de $\mathrm{Fe}$ (principalmente mackinawita e greigita) junto com as formas solúveis de sulfetos ( $(\mathrm{HS})$ ) são denominados como AVS (Sulfetos Voláteis em meio ácido), já que sua extração se realiza dissolvendo-os em $\mathrm{HCl}$ (1 ou 2M). $\mathrm{O} \mathrm{H}_{2} \mathrm{~S}$ gerado é arrastado por uma corrente de nitrogênio que é borbulhado em uma solução de acetato de $\mathrm{Zn}$, onde fica retido como $\mathrm{ZnS}$ (Morse et al., 1987). Estes sulfetos voláteis em meio ácido $\left[\mathrm{AVS}=\left(\sum \mathrm{HS}_{2}+\mathrm{FeS}+\mathrm{Fe}_{3} \mathrm{~S}_{4}\right)\right]$ podem atuar como sumidouro de elementos traço e, portanto controlar sua biodisponibilidade e toxicidade, assim como a pirita (Di Toro et al., 1990, 1992; Huerta-Díaz \& Morse, 1992; Morse, 1994).

\subsection{Elementos traço em solos de manguezais e marismas}

Rochas, solos, sedimentos e água apresentam em sua composição química quantidades variáveis de elementos traço. Em função das atividades antrópicas intensificadas, principalmente a partir do século $\mathrm{XX}$, esses conteúdos têm sido fortemente incrementados (Förster, 1990). Assim sendo, os solos apresentam elementos traço de origem natural e antrópica. Os de origem natural ocorrem principalmente, como componentes traços de minerais detríticos, ao passo que os de origem antrópica, advêm geralmente de acidentes com petróleo, descarga de efluentes, deposição de lixo, maricultura, silvicultura e salinas. Os elementos traço atingem os solos de manguezais e marismas através da deposição atmosférica, do transporte fluvial e por marés. Em muitos países, estes ecossistemas são utilizados como uma alternativa de baixo custo para o descarte e o tratamento de esgotos domésticos e industriais, devido a sua capacidade de retenção de inúmeros elementos que podem servir de nutriente, mas também podem se tornar prejudiciais à biota. 
$\mathrm{O}$ termo elemento traço tem sido utilizado para definir metais catiônicos e oxiânions que normalmente estão presentes no ambiente em baixas concentrações, usualmente < 1 g.kg $^{-1}$ (Pierzynski et al., 1994, Sparks, 1995), muito embora Al, Fe e Ti, os quais ocorrem em maiores concentrações na litosfera, principalmente em ecossistemas tropicais, também sejam tratados como elementos traço por alguns autores (McBride, 1994; Kabata-Pendias \& Pendias, 2001). Alguns são considerados essenciais do ponto de vista biológico, enquanto outros não o são. Entretanto, mesmo aqueles essenciais podem, sob condições específicas, causar impactos negativos a ecossistemas terrestres e aquáticos, constituindo-se assim, em contaminantes ou poluentes de solo e água. O termo poluente define uma substância química ou material fora do seu local de origem, em concentração acima do normal, que causa efeitos adversos em um organismo qualquer, diferindo do termo contaminante, pelo fato deste último não implicar, necessariamente, na existência de efeitos adversos (Pierzynski et al., 1994).

A capacidade do poluente de causar efeitos adversos é uma característica intrínseca e representa um risco em potencial ou perigo, o qual, aliado à possibilidade de exposição do indivíduo ou órgão ao poluente, resulta no risco propriamente dito (Graedel \& Allenby, 1995).

Menezes et al. (2000) destacam que estes elementos, apesar do poder de retenção dos solos dos manguezais e marismas, acabam atingindo a fauna e, consequentemente a cadeia alimentar, tornando-se um risco também para as populações humanas.

A poluição é geralmente categorizada em função de suas fontes, que podem ser classificadas em pontuais e não pontuais. A poluição pontual advém de fontes que podem ser identificadas, tais como uma indústria, uma fossa séptica ou uma estação de tratamento de água. Fontes de poluição não pontuais, são aquelas advindas de emissões que se propagam por uma extensa área, e se originam de atividades agrícolas, humanas, florestais, urbanas, de construção e mineração, além de deposição atmosférica (Pierzynski et al., 1994; Sparks, 1995).

A poluição dos solos e das águas por elementos traço é um importante fator que afeta tanto o ciclo geoquímico desses elementos quanto a qualidade ambiental. Nas 
últimas décadas, a poluição dos solos tem merecido especial atenção, sendo mundialmente reconhecida como um problema que pode representar sérios riscos à saúde humana e à qualidade do meio ambiente. Os solos possuem características únicas quando comparados aos outros componentes da biosfera (ar, água e biota), pois se apresentam não apenas como um dreno para contaminantes, mas também como um tampão natural que controla o transporte de elementos químicos e outras substâncias para a atmosfera, hidrosfera e biota (Kabata-Pendias \& Pendias, 2001).

Um solo contaminado, segundo Knox et al. (1999), é aquele cuja composição química difere da original, mas que não apresenta efeito prejudicial para os organismos. Por outro lado, a poluição do solo ocorre quando um elemento ou substância está presente em concentração maior que a natural, como resultado da atividade humana, o que causa efeito prejudicial para o ambiente e seus componentes.

Os solos dos sistemas estuarinos, manguezais e marismas, têm sido considerados como um compartimento de acumulação de espécies poluentes a partir da água de inundação, devido às altas capacidades de sorção e acumulação associadas, onde as concentrações tornam-se várias ordens de grandeza maiores do que nas águas correspondentes, possibilitando o uso dos mesmos como um bom indicador de poluição ambiental e também o conhecimento das principais fontes de poluição dentro de um determinado sistema aquático (Förstner \& Wittmann, 1981; Carvalho \& Lacerda, 1992). Contudo, diversos processos bióticos e abióticos podem remobilizar tais espécies, constituindo-se em fontes de poluição secundárias, afetando a qualidade da água e originando bioacumulação e trocas de transferência na cadeia trófica (Phillips, 1977). Em conseqüência, a liberação antrópica de elementos traço nos solos dos sistemas estuarinos tornou-se um problema ambiental de caráter eminente em todo mundo.

Os solos destes ambientes têm sido definidos como um complexo tridimensional com variação das condições redox (Wiegert et al., 1981), sendo que estas variações podem afetar significativamente a especiação dos elementos traço. Deste modo, em condições óxicas os elementos traço encontram-se associados principalmente aos oxihidróxidos de $\mathrm{Fe}$ (Giblin et al., 1986; Griffin et al., 1989), ao passo que em condições 
anóxicas os elementos traço precipitam principalmente como sulfetos ou co-precipitam com a pirita (Griffin et al., 1989; Huerta-Díaz \& Morse, 1993). Nestas condições a matéria orgânica também pode ocupar um papel importante, principalmente quando os metais não tendem a formar sulfetos ou é instável como é o caso do $\mathrm{Cr}^{3+}$ (Otero et al., 2000a).

Por estes motivos, os solos de manguezais e marismas podem atuar como sumidouro destes contaminantes, contribuindo para a diminuição de suas concentrações na água de inundação (Valiela et al., 1976).

É importante notar, entretanto, que marismas e manguezais podem também atuar como um sistema exportador líquido de materiais em suspensão e elementos traço. Durante os ciclos das marés de sizígia (luas cheia ou nova), é comum ocorrerem fortes correntes de marés erosivas, capazes de retirar e exportar material em suspensão e mesmo elementos traço destes sistemas para a baía aberta, já, durante os ciclos das marés de quadratura (luas quarto crescente ou minguante) o fenômeno se inverte. Estudos apontam que estes sistemas importam mais que exportam sedimentos e elementos traço (Lacerda et al., 1988).

Nos últimos anos realizou-se um grande esforço para entender os fatores que controlam o comportamento geoquímico dos elementos traço o que, por sua vez, está relacionado com a biodisponibilidade desses elementos (Tessier et al., 1979; 1984; Di Toro et al., 1990; Bryan \& Langston, 1992, Otero et al., 2000). A biodisponibilidade dos elementos traço não depende tanto do conteúdo total e sim da forma em que estes se encontram relacionados com os diferentes componentes que constituem o solo (matéria orgânica, argilas, oxihidróxidos de $\mathrm{Fe}$ e Mn, etc.). A bibliografia a respeito evidencia a existência de uma grande controvérsia com relação a este problema. Assim, Luoma \& Bryan (1981) consideram que a fração extraída com $\mathrm{HCl} 1 \mathrm{M}$ se encontra fracamente unida ao sedimento e, portanto, representa uma das fases sedimentares potencialmente biodisponível. Por outro lado, outros autores estabelecem que os elementos traço associados à matéria orgânica, e também os que estão associados aos oxihidróxidos de Fe e de Mn, têm um efeito protetor sobre a bioacumulação de metais (Tessier et al., 
1984, Han et al., 1996). Contudo, para predizer o destino dos elementos traço no solo em longo prazo, é imprescindível o conhecimento das suas principais formas, combinação e prováveis transformações no ambiente (Beckett, 1989). À identificação das diferentes formas e fases na qual um elemento ocorre, utiliza-se o termo especiação (Ure, 1990).

A extração seqüencial é apontada como uma das formas para avaliar a especiação dos metais em solos e sedimentos e baseia-se na dissolução seletiva das frações dos solos ou sedimentos, nas quais se encontram as diferentes formas dos metais. Desta maneira, é possível obter informações detalhadas que permitam avaliar a forma química de origem, o modo de ocorrência, as disponibilidades física, química e biológica, a mobilização e o transporte de metais em sedimentos (Tessier et al., 1979). Utiliza-se para tal fim, de uma seqüência de reagentes seletivos, cada vez mais fortes, apropriados para a liberação dos metais ligados em diferentes frações que compõem o sedimento. Esta metodologia recebeu críticas devido aos reagentes não extraírem formas químicas distintas e pela possibilidade de ocorrer readsorção e redistribuição dos metais durante o processo.

Em ambientes anóxicos o produto final da redução dos sulfatos é a pirita (Howarth, 1984), a qual pode atuar como um importante sumidouro de elementos traço (Huerta-Díaz \& Morse, 1992). No entanto, poucas vezes esta fração tem sido considerada de forma independente devido a que o método mais utilizado é o proposto por Tessier et al. (1979), o qual não diferencia esta fração e a orgânica (Otero-Pérez, 2000). Em condições anóxicas, a maioria dos sulfetos metálicos são poucos solúveis e estáveis (Krauskopf, 1956). As formas preferenciais dos metais bivalentes em solos de meios estuarinos devem ser os sulfetos insolúveis ( $\mathrm{CdS}, \mathrm{HgS}, \mathrm{NiS}, \mathrm{CuS}, \mathrm{ZnS}, \mathrm{PbS}$ ), bastante estáveis nas condições anóxicas presentes nesses solos. Entretanto, é possível que estes meios sejam submetidos a alterações temporais em suas condições redox (p.ex. bioperturbação, alteração das marés,...) que podem ocasionar uma oxidação da pirita com a subseqüente liberação dos metais associados, aumentando desta maneira sua biodisponibilidade (Morse, 1994). 
A redução do sulfato a $\sum \mathrm{HS}_{2}\left(=\mathrm{H}_{2} \mathrm{~S}+\mathrm{HS}^{-}+\mathrm{S}^{\overline{ }}\right)$ é considerado como o principal processo na mineralização da matéria orgânica em solos anóxicos (Howarth, 1984). Uma parte do $\sum \mathrm{HS}_{2}$ pode reagir com o $\mathrm{Fe}^{2+}$ e gerar sulfetos de ferro metaestáveis tais como, FeS amorfo, mackinawita (FeS), greigita $\left(\mathrm{Fe}_{3} \mathrm{~S}_{4}\right)$ (Morse et al., 1987), os quais posteriormente podem ser transformados em pirita $\left(\mathrm{FeS}_{2}\right)$ (Berner, 1970). As técnicas analíticas atuais não permitem uma separação quantitativa destas formas de modo que tradicionalmente, nos estudos sobre os sulfetos de Fe em sedimentos e solos, se estabelecem do ponto de vista operacional, duas categorias: sulfetos voláteis em meio ácido (AVS) e pirita (Morse et al., 1987).

A fração AVS se extrai mediante uma destilação em ácido (solução diluída de $\mathrm{HCl}$ ) (Cornwell \& Morse, 1987), enquanto que a pirita resiste a este ataque ácido e, portanto é determinada por oxidação com $\mathrm{HNO}_{3}$ (Huerta-Díaz \& Morse, 1990).

A análise dos sulfetos voláteis em meio ácido (AVS) vem sendo usada para explicar os resultados dos testes de toxicidade para metais em sedimentos (Di Toro et al., 1992; Allen et al., 1993; Correia \& Costa, 2000; Ngiam \& Lim, 2001; Caetano et al., 2003; Praharaj \& Fortín, 2004). De acordo com Di Toro et al. (1990, 1992) a biodisponibilidade e toxicidade dos metais divalentes $(\mathrm{Hg}, \mathrm{Cd}, \mathrm{Ni}, \mathrm{Cu}, \mathrm{Zn}, \mathrm{Pb} . .$.$) em$ sedimentos marinhos anóxicos parece estar controlada pela relação SEM/AVS, onde SEM (Metal Extraído Simultaneamente) é o somatório da concentração molar dos metais divalentes extraídos simultaneamente durante a destilação da fração AVS; ou seja, são metais solúveis em $\mathrm{HCl} 1 \mathrm{M}$. Quando esta relação é inferior a 1 , não há toxicidade aguda para diferentes espécies de macro invertebrados, devido à concentração dos metais estar controlada pelos sulfetos $\left(\mathrm{FeS}+\mathrm{Me}^{2+} \rightarrow \mathrm{MeS}+\mathrm{Fe}\right)$. A concentração na água intersticial será muito reduzida, já que o produto de solubilidade dos sulfetos metálicos é muito reduzido e inferior ao da mackinawita.

Aplicando esta idéia ao meio natural, o modelo do AVS pode ser de utilidade para predizer a disponibilidade e toxicidade dos metais para uma ampla espécie de animais bentônicos (Di Toro et al., 1990, 1992), embora existam trabalhos, onde evidencias apontam que, este modelo pode funcionar no laboratório, mas sua aplicação 
em condições naturais oferece muitas dúvidas, devido principalmente a concentração de AVS e pirita estar submetida a uma constante reciclagem que modificaria significativamente a relação SEM/AVS (Hare et al., 1994). 


\section{MATERIAL E MÉTODOS}

\section{1 Área de estudo}

\subsubsection{Ambiente estuarino de clima tropical (Brasil)}

\section{Baixada Santista}

A Baixada Santista, formada pelos municípios de Bertioga, Cubatão, Guarujá, Itanhaém, Mongaguá, Praia Grande, Santos, e São Vicente (Figura 3.1), localiza-se no litoral central do Estado de São Paulo sob as coordenadas $24^{\circ} 50^{\prime} \mathrm{S}, 46^{\circ} 45^{\prime} \mathrm{W}$ e $23^{\circ} 45^{\prime}$ 'S, $45^{\circ} 50^{\prime} \mathrm{W}$. O clima é quente e úmido na maior parte do ano, com média anual superior a $20^{\circ} \mathrm{C}$ de temperatura e pluviosidade anual em torno de 2000 a $2500 \mathrm{~mm}$, com maior incidência nos meses de verão, porém, não há uma estação considerada realmente seca na região (SMA - CETESB, 1999). As marés são semi-diurnas, com alturas máximas de 1,6 $\mathrm{m}$ acima do nível médio que é de $0,77 \mathrm{~m}(\mathrm{DHN}, 1984)$.

É uma área de transição entre o litoral norte, com planície costeira muito estreita, e o litoral sul, com planície mais desenvolvida, formadas por deposição marinha. Nesta unidade, identificam-se, na realidade, três baixadas alternadas entre as proeminências da Serra do Mar, sendo elas: de Bertioga, Santos e Itanhaém, onde a intermediária se constitui em um verdadeiro golfão, quase fechado por duas importantes ilhas (a de Santo Amaro e a de São Vicente) que são estreitamente ligadas ao continente (Azevedo, 1965). As ilhas dessa unidade juntamente com as do litoral sul, são predominantemente sedimentares (SMA, 1999).

A região da Baixada Santista pode ser classificada como uma planície sedimentar constituída por cinco compartimentos distintos: a Planície da Praia Grande, o Estuário de Santos, a Ilha de Santo Amaro, a Planície de Bertioga e as Escarpas da Serra do Mar (Silva et al., 1994). 


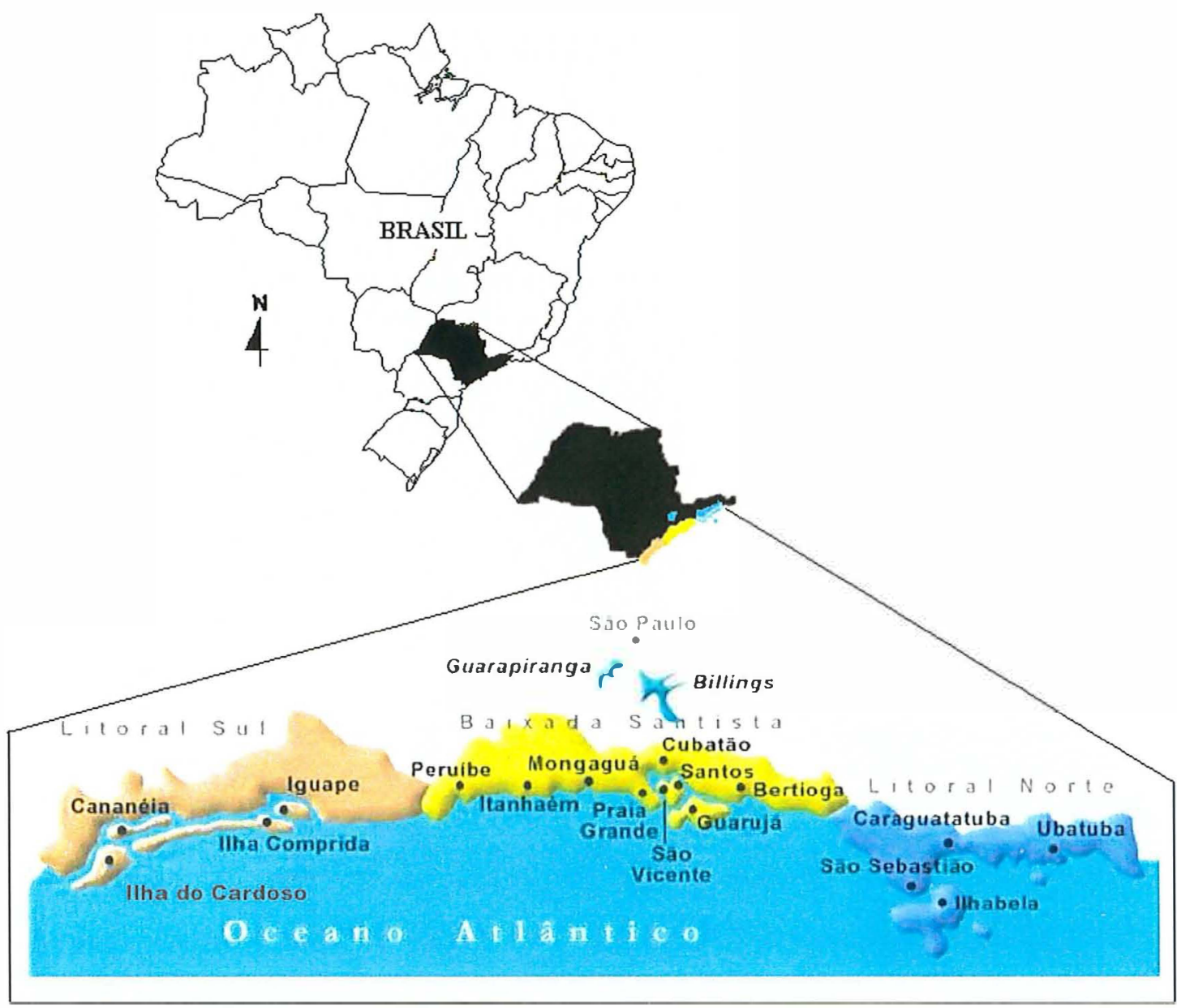

Figura 3.1 - Localização gráfica do litoral paulista

\section{Ilha do Cardoso}

O Parque Estadual da Ilha do Cardoso pertence ao município de Cananéia-SP e está localizado no extremo sul do litoral paulista $\left(25^{\circ} 03^{\prime} \mathrm{S}\right.$ e $\left.47^{\circ} 55^{\prime} \mathrm{W}\right)$, na divisa com o Estado do Paraná, abrangendo uma área de aproximadamente $151 \mathrm{~km}^{2}$ (Figura 3.1). Trata-se de uma área de Proteção Ambiental (APA) administrada pelo Instituto Florestal da Secretaria de Meio Ambiente do Estado de São Paulo. Faz parte do ComplexoEstuarino-Lagunar, Iguape-Cananéia-Paranaguá (unidade ecológica na qual em sua extensão de quase $200 \mathrm{~km}$ é constante a presença de manguezais e mares interiores), encontrando-se no centro. Limita-se a leste com o Oceano Atlântico, a norte e nordeste com a Baía de Trapandé e a oeste e ao sul com as águas do Canal de Ararapira. 
A região estuarina de Cananéia, na qual a Ilha do Cardoso está inserida, apresenta clima sub-tropical, com uma precipitação média anual de $2.200 \mathrm{~mm}$, temperatura média anual de $21,2^{\circ} \mathrm{C}$. A amplitude média de maré é de $0,82 \mathrm{~m}$ (SchaefferNovelli, 1982).

O relevo da Ilha do Cardoso é predominantemente montanhoso, sendo sua porção central ocupada por um maciço rochoso que atinge aproximadamente 900 metros de altitude, constituídos de rochas do Pré-Cambriano Inferior, onde ocorrem gnaisses e micaxistos, por entre os quais afloram rochas magmáticas (granitos) (Negreiros et al., 1974). As extremidades norte e sul da Ilha do Cardoso possuem um relevo baixo, formado por depósitos arenosos recentes; e especificamente em relação à extremidade sul da Ilha, esta se destaca por uma longa planície arenosa, em cuja vertente oeste dominam os manguezais (Barros et al. 1991). Em sua face leste, o maciço mergulha no Oceano Atlântico originando o litoral escarpado. Ao norte e nordeste limita-se com a Baía de Trapandé e a oeste e ao sul faz divisa com o Canal do Ararapira:

\subsubsection{Ambiente estuarino de clima temperado (Espanha)}

\section{Costa da Galícia}

A Galícia compreende $1.195 \mathrm{~km}$ de costa, dos quais 820 correspondem a acantilados, e outros 278 a praias.

Geograficamente, um dos pontos mais importantes da Galícia é a presença das rías que dividem a costa galega em duas regiões, rías altas e rías baixas.

A costa galega apresenta uma ampla variedade geológica. Nas regiões em estudo as unidades litológicas mais importantes são: Marisma de Ortigueira, rochas metamórficas ricas em minerais ferromagnesianos e pobres em silício como anfibolitas, granulitas, eclogitas e ultrabásicas como as peridotitas serpentinizadas. Marismas de Caldebarcos e Pontevedra, rochas plutônicas ácidas, fundamentalmente granitos e granodioritas.

O clima que caracteriza grande parte da Costa Galega é do tipo temperado úmido com a temperatura média anual de $12,9^{\circ} \mathrm{C}$, sendo que a variação de temperatura no inverno é de 5 a $10^{\circ} \mathrm{C}$ e no verão de 15 a $20^{\circ} \mathrm{C}$. A precipitação média anual oscila entre 
930 a $1062 \mathrm{~mm}$, concentrando-se, sobretudo no outono, inverno e primavera. As precipitações dos meses mais secos, junho a agosto, mostram uma importante diminuição pluviométrica neste período, caracterizando verões secos (Carballeira et al., 1983).

\subsection{Amostragem}

\subsubsection{Manguezais do Estado de São Paulo}

Foram amostrados 15 perfis de solos procedentes de diferentes manguezais do litoral paulista. As amostragens foram realizadas sob maré baixa durante os anos $2001 \mathrm{e}$ 2003. A escolha das áreas de amostragem teve como principal critério o tipo de contaminação que recebe cada manguezal descrito abaixo:

\section{Manguezal do Rio Irirí (Bertioga-SP)}

A área está compreendida entre $46^{\circ} 12^{\prime} 28^{\prime \prime}$ e $46^{\circ} 12^{\prime} 29^{\prime \prime}$ de Longitude Oeste e

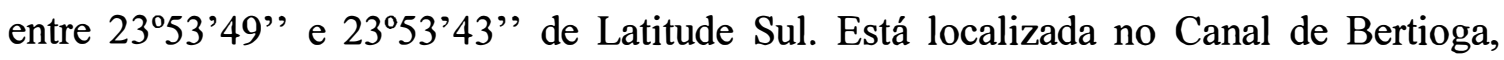
pertencente ao Município de Bertioga (SP). O manguezal em questão encontra-se em uma região impactada com petróleo. Em outubro de 1983, ocorreu o derrame de petróleo no manguezal do canal de Bertioga, causado pelo rompimento do oleoduto da Petrobrás. O vazamento aconteceu no quilômetro 93 da rodovia Rio-Santos e, aproximadamente, 2,5 milhões de litros de petróleo fora lançados nos mangues próximos à estrada e, via rio Irirí, atingiram o Canal de Bertioga A amostragem foi realizada em uma transeção constituída de três pontos, referentes à zona da margem do rio (P3), zona alagada (P16) e zona de contato mangue-encosta (P28), obedecendo a um gradiente de impactação (Figura 3.2).

\section{Manguezal do Rio Crumahú (Guarujá-SP)}

Está localizado no município do Guarujá $\left(23^{\circ} 59^{\prime} \mathrm{S}\right.$ e $\left.46^{\circ} 15^{\prime} \mathrm{W}\right)$, na conhecida Ilha de Santo Amaro.

O manguezal do Rio Crumahú fica próximo aos Bairros Morrinho e Vila Zilda. Esta área encontra-se fortemente afetada pela deposição contínua de efluentes de águas 
servidas (esgoto doméstico) provenientes do bairro Morrinhos, no qual residem aproximadamente umas 40.000 famílias (Firme, 2003). Nesta área a amostragem foi realizada as margens do rio Crumahú, seguindo o curso do rio em direção ao Canal de Bertioga e obedecendo a um gradiente de impacto, correspondendo o T1P1 a área próxima à fonte de contaminação e $\mathrm{PC} 8$ e PC15, ao longo do rio (Figura 3.2).

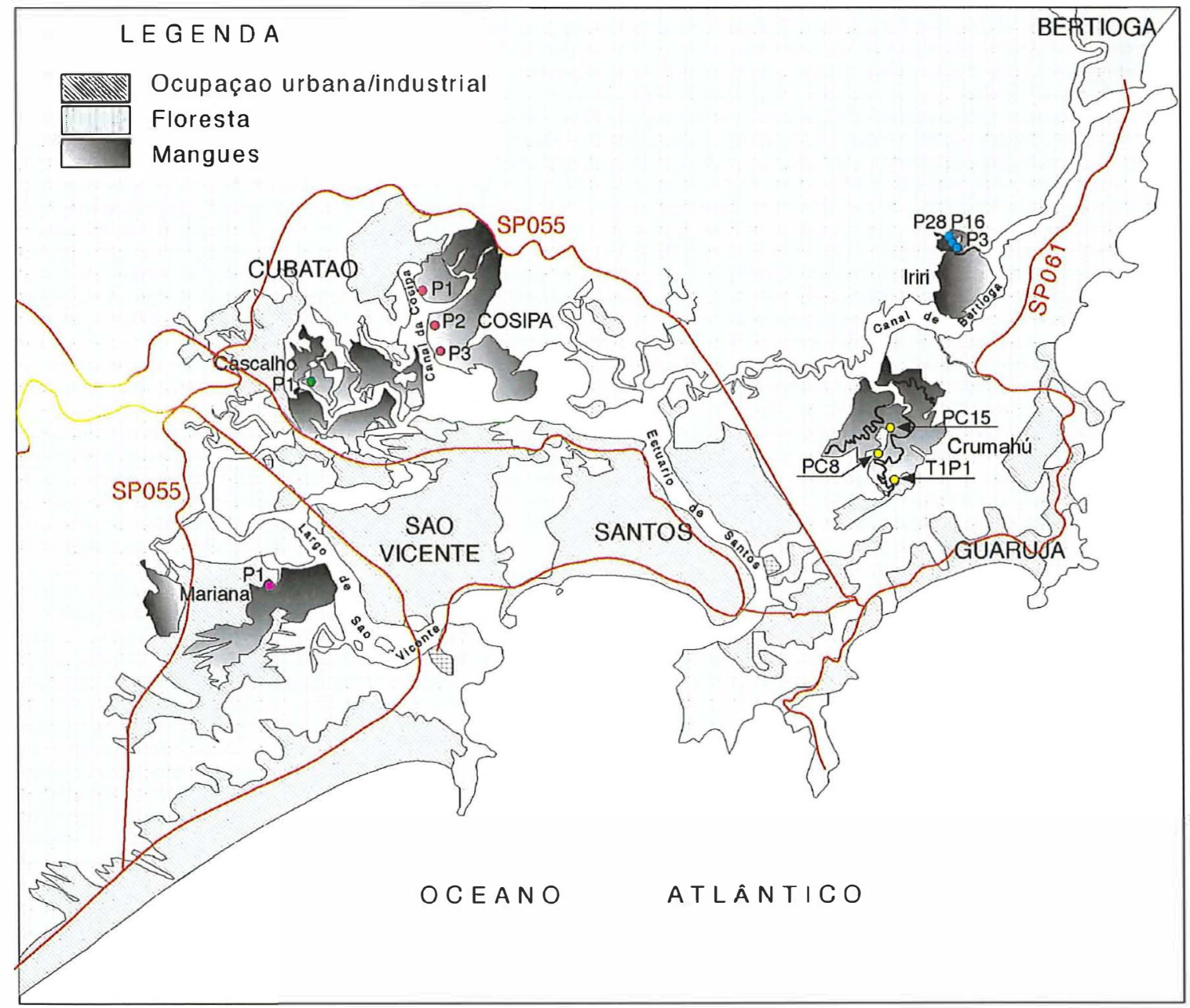

Figura 3.2 - Representação gráfica dos pontos de amostragem das áreas dos manguezais da Baixada Santista 


\section{Manguezal do Canal da COSIPA (Cubatão-SP)}

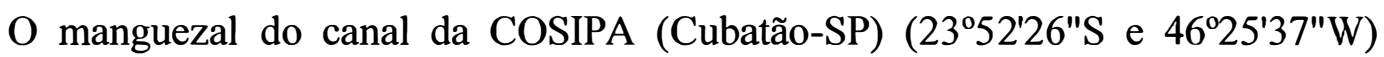
corresponde a uma zona fortemente poluída por efluentes industriais do ramo petroquímico e siderúrgico, além das atividades portuárias. A amostragem foi realizada às margens do canal da COSIPA procurando seguir um gradiente de impacto, correspondendo o ponto $\mathrm{P} 1$ à zona mais próxima ao porto da COSIPA e P2 e P3 ao longo do canal, distanciando-se do porto da indústria em direção ao porto de Santos (Figura 3.2).

\section{Manguezal do Rio Cascalho (Cubatão-SP)}

O manguezal do rio Cascalho (Cubatão-SP) (2352'26"S e 46 $\left.25^{\prime} 37^{\prime \prime} \mathrm{W}\right)$, na verdade um canal de maré, é afetado por fontes de contaminação difusa (industrial e doméstica) e recebeu um único ponto de amostragem (P1) (Figura 3.2).

\section{Manguezal do Rio Mariana (São Vicente-SP)}

O manguezal do rio Mariana (São Vicente-SP) (23⒌'35'’S e $46^{\circ} 23^{\prime} 15^{\prime \prime} \mathrm{W}$ ) é, há mais de 20 anos, afetado por deposição indiscriminada de esgoto doméstico e de alguma pequena indústria clandestina, sendo que também pode ter tido alguma contaminação procedente de depósitos de rejeitos de organoclorados deixados na restinga adjacente, procedentes da empresa Rhodia e depositados durante os anos $60 \mathrm{e}$ 70. Esta área também recebeu um único ponto de amostragem (P1) (Figura 3.2).

\section{Manguezal da Ilha do Cardoso (Cananéia-SP)}

Os manguezais do Parque Estadual da Ilha do Cardoso (Cananéia-SP) representam à situação de uma área não afetada por deposições contaminantes. Para esta zona foram considerados um total de 4 pontos de amostragem. A amostragem foi realizada em diferentes tipos de mangue em função da vegetação, correspondendo o ponto P1 ao manguezal do rio Jaguaparíu (Sítio Grande), com predomínio de Rhizophoras, Avicennias e Laguncularias em menor proporção e, em direção ao oceano, uma franja com spartinas, a alguns metros de distância do ponto de amostragem; o ponto 
P2 ao manguezal do rio Jaguaparíu, com predomínio de Rhizophora e Avicennias em menor proporção; o ponto P3 ao manguezal do rio Ipaneminha com predomínio de Laguncularias e Rhizophoras em menor proporção e, o ponto P4 ao manguezal do rio Perequê, com domínio total de Rhizophoras (Figura 3.3).

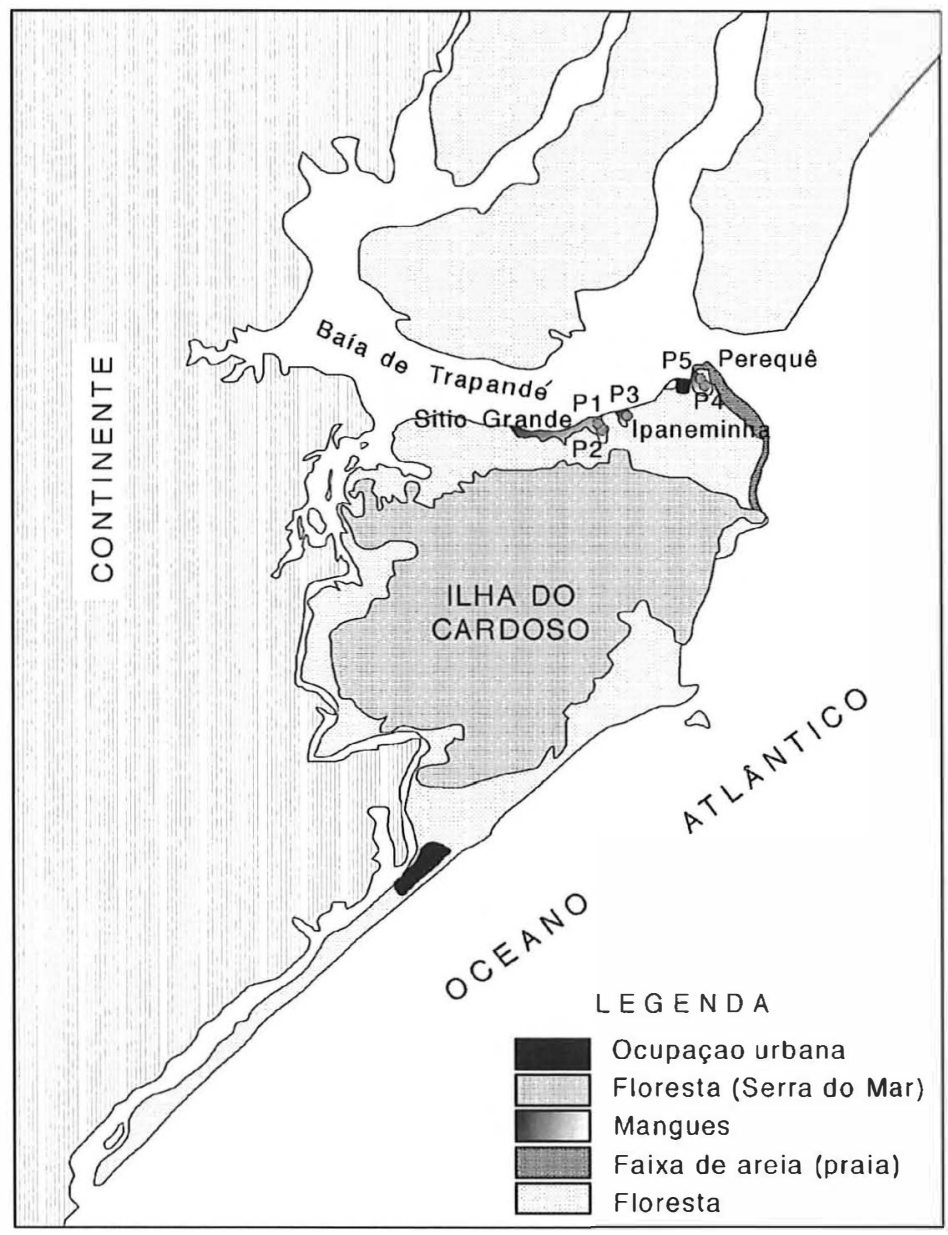

Figura 3.3 - Representação gráfica dos pontos de amostragem dos manguezais da Ilha do Cardoso

\subsubsection{Sistemas de Marisma da Galicia}

Foram amostrados 5 perfis de solos procedentes de marismas distintas, distribuídas ao longo da costa da Galícia. As amostragens foram realizadas sob maré baixa no ano de 2004. A escolha das áreas de amostragem teve como principal critério o tipo de contaminação que recebe cada sistema de marisma descrito abaixo: 


\section{Marisma de Ortigueira}

Esta zona de estudo localiza-se na enseada de Esteiro na Ría de Ortigueira (Figura 3.4), situada no limite de município entre Ortigueira e Cariño pertencentes à província de A Coruña na Galícia. Trata-se de uma região impactada por resíduos de uma pedreira de dunitas (peridotita serpentinizada). A amostragem foi realizada em dois pontos.

Um dos pontos corresponde a uma área colonizada pela espécie Zostera nolti, apresentando um solo anóxico já em superfície. O segundo ponto, separado do anterior por apenas $2 \mathrm{~m}$, está colonizado pela gramínea Spartina marítima. Neste segundo caso o solo é subóxico em superfície e anóxico abaixo dos $15 \mathrm{~cm}$.

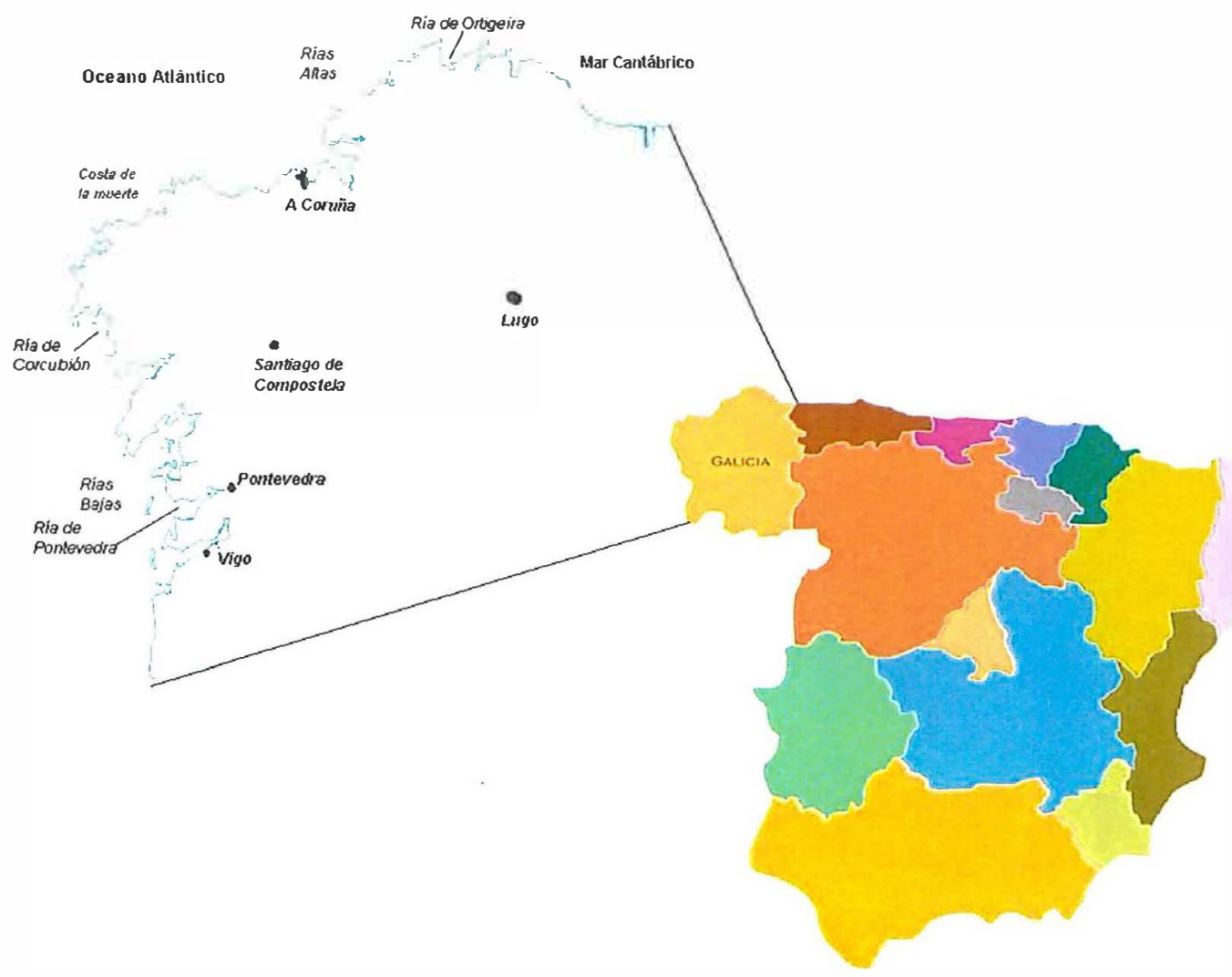

Figura 3.4 - Localização gráfica da costa da Galícia 


\section{Marisma de Caldebarcos}

Esta área localiza-se na Ría de Corcubión (Figura 3.4) situada no município de Carnota pertencente à província de A Coruña no oeste da Galícia. A marisma de Caldebarcos se localiza na parte norte da praia de Carnota (maior praia da Galícia) até a Punta de Caldebarcos. Trata-se de uma zona impactada por petróleo derramado pelo petroleiro Prestige em novembro de 2002. A amostragem foi realizada em dois pontos.

\section{Marisma de Alba (Pontevedra)}

Esta área de estudo localiza-se na Ría de Pontevedra (Figura 3.4) situada no município de Pontevedra na Galícia. Trata-se de uma área impactada por esgotos urbanos da própria cidade de Pontevedra e efluentes de um complexo de indústrias de celulose. A amostragem foi realizada em dois pontos.

\subsubsection{Coleta das amostras}

As amostras semi-deformadas foram obtidas através do uso de tubos de policarbonato com $5 \mathrm{~cm}$ de diâmetro interno e $50 \mathrm{~cm}$ de comprimento (Amostrador para sedimentos marinhos - Cole Parmer Instrument - Figura 3.5). As amostragens foram realizadas com três repetições por ponto, conservadas em caixa de isopor com gelo à aproximadamente $4^{\circ} \mathrm{C}$ e transportadas na posição vertical ao laboratório. As amostras foram estratificadas em secções com as seguintes espessuras: 0-1; 1-3, 3-4; 4-5; 5-10; $10-15 ; 15-20 ; 20-25 \mathrm{~cm}$. Foram coletadas, também, amostras semi-deformadas com o auxílio do Amostrador para solos inundados (Napoleão - Figura 3.5), nas profundidades: $0-5 ; 5-10 ; 10-15 ; 15-20 ; 20-25 ; 25-40$ e Gley (@60-90cm), obedecendo ao mesmo critério usado para o outro amostrador. Após a estratificação as amostras foram congeladas para as análises posteriores. 


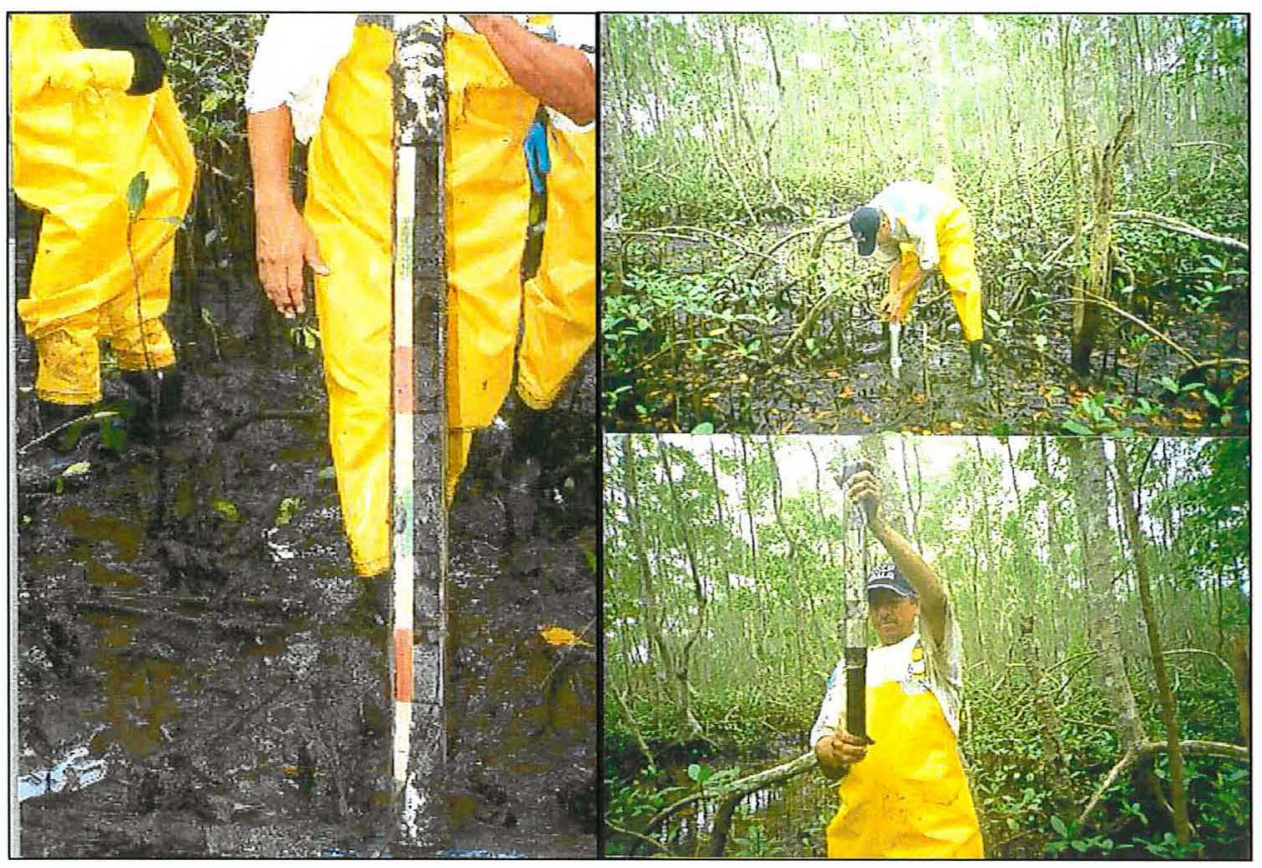

Figura 3.5 - Amostrador para solos inundados, Napoleão (à esquerda) e amostrador para sedimentos marinhos (à direita)

\subsection{Análise das amostras}

$\mathrm{O} \mathrm{pH}$ e o potencial redox (Eh) foram determinados no campo no momento da amostragem. O Eh foi determinado utilizando um eletrodo combinado de platina, tomando os valores de Eh quando a variação foi inferior a $\mathrm{mV} \cdot \mathrm{min}^{-1}$. O valor obtido foi corrigido adicionando o potencial do eletrodo de referência em relação ao eletrodo padrão de hidrogênio (244 mV). O conteúdo de carbono orgânico total (TOC) e o de S total foram determinados em analisadores elementares, sendo o Leco $\mathrm{CNH}-1000$ para o TOC e o Leco 100 S-C 144DR para o S total.

O método de fracionamento seguido para os metais traço foi uma combinação de métodos anteriores propostos para meios sedimentares por Tessier et al., (1979), HuertaDíaz \& Morse (1990 e 1992) e Fortín et al., 1993. A combinação destes métodos nos permite diferenciar 6 frações que operacionalmente foram definidas como:

Fl - Fe e elementos traço trocáveis: foram extraídos através de $30 \mathrm{~mL}$ solução de $\mathrm{MgCl}_{2} 1 \mathrm{M}$ à $\mathrm{pH} 7,0$ (ajustado com $\mathrm{NaOH} 0.1 \mathrm{M}$ ), agitadas por 30 minutos e centrifugadas à $10000 \mathrm{rpm} \mathrm{e} 4^{\circ} \mathrm{C}$, por 30 minutos. 
F2 - Fe e elementos traço associados aos carbonatos: foram extraídos através de $30 \mathrm{~mL}$ de uma solução de $\mathrm{NaOAc} 1 \mathrm{M}$ à pH 5,0 (ajustado com Ác. Acético concentrado), agitados por 5 horas e centrifugadas à $10000 \mathrm{rpm} \mathrm{e} 4^{\circ} \mathrm{C}$, por 30 minutos.

F3 - Fe e elementos traço associados à ferridrita: foram extraídos através de 30 $\mathrm{mL}$ de uma solução de hidroxilamina $0,04 \mathrm{M}+$ Ác. Acético $25 \%(\mathrm{v} / \mathrm{v})$, à $30^{\circ} \mathrm{C}$, agitados por 6 horas e centrifugadas à $10000 \mathrm{rpm}$ e $4^{\circ} \mathrm{C}$, por 30 minutos.

F4 - Fe e elementos traço associados à lepidocrocita: foram extraídos através de $30 \mathrm{~mL}$ de uma solução de hidroxilamina $0,04 \mathrm{M}+$ Ác. Acético $25 \%(\mathrm{v} / \mathrm{v})$, à $96^{\circ} \mathrm{C}$, agitados por 6 horas e centrifugadas à $10000 \mathrm{rpm}$ e $4^{\circ} \mathrm{C}$, por 30 minutos.

Estas duas últimas frações acima (F3, F4) possivelmente também podem extrair elementos traço associados a óxidos de manganês (Chester \& Hughes, 1967).

F5 - Fe e elementos traço associados à oxihidróxidos de Fe cristalinos (goethita, hematina): foram extraídos através de $20 \mathrm{~mL}$ de uma solução de citrato de sódio $0,25 \mathrm{M}$ + bicarbonato de sódio $0,11 \mathrm{M}$ e $3 \mathrm{~g}$ de ditionito de sódio, à $75^{\circ} \mathrm{C}$, agitados por 30 minutos e centrifugadas à $10000 \mathrm{rpm} \mathrm{e} 4^{\circ} \mathrm{C}$, por 30 minutos.

Previamente à extração da pirita, a amostra foi tratada durante $16 \mathrm{~h} \mathrm{com} 30 \mathrm{ml}$ de ácido fluorídrico $10 \mathrm{M}$ para eliminar o Fe e os elementos traço associados aos silicatos e posteriormente com $10 \mathrm{ml}$ de ácido sulfúrico concentrado para eliminar o $\mathrm{Fe}$ e os elementos traço associado à matéria orgânica (para mais detalhes ver Huerta-Díaz \& Morse, 1990, 1992).

F6 - Fe e elementos traço associados à pirita: foram extraídos finalmente utilizando para isso ácido nítrico concentrado. As amostras foram mantidas em agitação durante 2 horas à temperatura ambiente, lavando-se o resíduo com $15 \mathrm{ml}$ de água ultrapura.

Entre cada extração o resíduo foi lavado duas vezes com $20 \mathrm{ml}$ de água ultrapura desoxigenada.

O grau de piritização do $\mathrm{Fe}$ (DOP) foi determinado segundo a equação:

$$
D O P(\%)=\left(\frac{F e-\text { pirítico }}{F e-\text { reativo }+F e-\text { pirítico }}\right) \times 100
$$


que estabelece a porcentagem de Fe reativo que foi incorporada na fração pirítica (Berner, 1970). Em nosso caso, considerou-se como $\mathrm{Fe}$ reativo a somatória do $\mathrm{Fe}$ extraído nas frações F1, F2, F3, a somatória de F1, F2, F3 e F4 e a somatória de F1, F2, F3, F4 e F5 e ainda o Fe extraído com $\mathrm{HCl} 1 \mathrm{M}$.

O grau de piritização dos metais (DTMP), termo proposto por Huerta-Díaz \& Morse (1990) e que é considerado como uma estimativa da quantidade de um determinado elemento traço $(\mathrm{Me})$ que foi incorporado na fração pirítica, foi calculado utilizando a seguinte equação:

$$
\operatorname{DTMP}(\%)=\left(\frac{M e-\text { piritico }}{M e-\text { reativo }+ \text { Me }- \text { piritico }}\right) \times 100
$$

A determinação do conteúdo total de elementos traço nos solos, a partir da extração com $\mathrm{HNO}_{3} / \mathrm{HF}(3 / 5 \mathrm{v} / \mathrm{v})$ em tubos de teflon em microondas de $700 \mathrm{~W}$ conforme Carral et al. (1995), utilizando um aparelho ICP-OES (Perkin-Elmer, modelo Optima 4300 DV).

A concentração dos sulfetos voláteis em meio ácido (AVS), determinada em triplicata segundo o método de Kostka \& Luther (1994). Os sulfetos da fração AVS foram liberados na forma de $\mathrm{H}_{2} \mathrm{~S}$ em um frasco de reação tampado, a partir de $\sim 1,000 \mathrm{~g}$ de solo úmido com $25 \mathrm{~mL}$ de $\mathrm{HCl} \mathrm{IN}$ (desoxigenado durante 40-50 minutos), homogeneizado e submetido a um fluxo de nitrogênio, borbulhado lentamente durante 40 minutos, sob agitação constante. Os sulfetos liberados foram arrastados através do fluxo de $\mathrm{N}_{2}$, até um segundo frasco que continha $25 \mathrm{~mL}$ de solução de $\mathrm{ZnOAc} 3 \%$, ficando os sulfetos retidos como $\mathrm{ZnS}$. Transcorrido o tempo de espera, adicionou-se à solução de $\mathrm{ZnOAc}, 1 \mathrm{~mL}$ de $\mathrm{H}_{2} \mathrm{SO}_{4}$ concentrado e $4 \mathrm{~mL}$ de reativo de diamida B. Este reativo foi preparado segundo as instruções de Cline(1969): 1,6 $\mathrm{g}$ de sulfato de 4-amino$\mathrm{N}$, N-dimetilanilina e $2,4 \mathrm{~g}$ de $\mathrm{FeCl}_{3} \cdot 6 \mathrm{H}_{2} \mathrm{O}$ em $100 \mathrm{~mL}$ de $\mathrm{HCl} 50 \%$ (v/v). Após 30 minutos, a concentração de sulfetos foi determinada por colorimetría através de um espectrofotômetro UV-VIS a um comprimento de onda de $670 \mathrm{~nm}$ (FEMTO - 600 plus).

A curva padrão de sulfeto foi preparada a partir de um padrão de sulfeto de 1000ppm (7,506 g. $\mathrm{L}^{-1}$ de $\mathrm{Na}_{2} \mathrm{~S} .9 \mathrm{H}_{2} \mathrm{O}$ em água ultrapura desoxigenada por $40-50$ minutos), de modo que se obteve as concentrações de 0,$00 ; 0,10 ; 0,20 ; 0,40$ e 1,00 ppm 
de $\mathrm{S}^{2-}$ em solução de $\mathrm{ZnOAc} 3 \%$. Uma alíquota de $25 \mathrm{~mL}$ de cada padrão foi transferida para tubos de ensaio e na sequiência foram adicionados $1 \mathrm{~mL}$ de $\mathrm{H}_{2} \mathrm{SO}_{4}$ concentrado e 4 $\mathrm{mL}$ de reativo de diamida $\mathrm{B}$. Após 30 minutos, a concentração de sulfetos foi determinada através de um espectrofotômetro UV-VIS a um comprimento de onda de $670 \mathrm{~nm}$.

No extrato do solo em $\mathrm{HCl} 1 \mathrm{M}$ filtrado foram analisados os metais divalentes (SEM), através de um aparelho ICP-OES (Perkin-Elmer, modelo Optima 4300 DV) (Di Toro et al. 1990, 1992).

\section{Processos analíticos gerais}

Os aparelhos de campo e de laboratório utilizados, durante a retirada e durante as análises das amostras, foram lavados com uma solução de $\mathrm{HCl}$ (1\%) durante uma noite e posteriormente foram enxaguados com água destilada e água ultrapura (Milli-Q). As concentrações foram expressas em peso seco. O conteúdo de água foi determinado a partir das amostras secas a $105^{\circ} \mathrm{C}$ até peso constante. As concentrações de $\mathrm{Fe}, \mathrm{Mn}$ e de elementos traço foram determinadas com um aparelho ICP-OES (marca Perkin-Elmer). Os brancos e os padrões, assim como as diferentes soluções utilizadas, foram preparadas sempre com água ultrapura e com reagentes de alta qualidade. 


\section{RESULTADOS E DISCUSSÃO}

\subsection{Caracterização e conteúdo total de elementos traço nos solos de manguezais e marisma.}

\subsubsection{Características gerais dos solos}

\subsubsection{Manguezais}

\section{Reação dos solos}

Nas Figuras 4.1 a 4.5 estão apresentados os gráficos com os valores de pH e Eh dos solos dos manguezais dos rios Irirí, Crumahú, Mariana, Cascalho, do canal da COSIPA e da Ilha do Cardoso em função da profundidade.

De forma geral, os valores de pH estão variando entre 5,5 (Irirí P3, $25 \mathrm{~cm}$ ) e 7,7 (canal da COSIPA P1, $50 \mathrm{~cm}$ ). Trata-se, no entanto, de solos com $\mathrm{pH}$ neutro ou ligeiramente ácido. Estes resultados coincidem com os obtidos para o mesmo tipo de solos em trabalhos anteriores, onde se estabelece que os valores limites de $\mathrm{pH}$ para solos submetidos a condições anaeróbicas variam entre 6,7 a 7,2 (Ponnamperuma, 1972). Entretanto, o autor destaca, que limites inferiores a estes, são comuns em solos de manguezais devido à presença de ácidos húmicos. A correlação negativa e altamente significativa encontrada entre a quantidade de raízes vivas e o $\mathrm{pH}\left(\mathrm{r}_{\mathrm{s}}=-0,821, \mathrm{p}<0,001\right.$, $\mathrm{n}=18$ ), assim como com o conteúdo de AVS nos solos (Figura 4.6) indicam que os valores de $\mathrm{pH}$ mais ácidos estão relacionados com o efeito oxidante que a vegetação exerce sobre estes solos. Trabalhos anteriores já estabeleceram uma relação inversa entre a densidade de pneumatóforos de Avicennia e Rhizophora e a concentração de sulfetos na água intersticial dos solos de manguezais (McKee et al., 1988). Entretanto, não se encontrou relação com a concentração da pirita, sendo que, a oxidação provocada pela liberação de ar através das raízes parece afetar fundamentalmente às formas de sulfetos mais lábeis $\left(\mathrm{SH}^{-}, \mathrm{FeS}, \mathrm{Fe}_{3} \mathrm{~S}_{4}, \ldots\right)$. 
Com relação às condições redox, todos os solos apresentaram valores de $\mathrm{Eh}<100$, indicando que são ambientes anóxicos e em alguns casos (COSIPA P2 e P3, Figura 4.3; Mariana P1, Figura 4.4) nas maiores profundidades, Eh $\sim-180$, indicando ambientes fortemente reduzidos. 
Manguezal do Rio Iriri

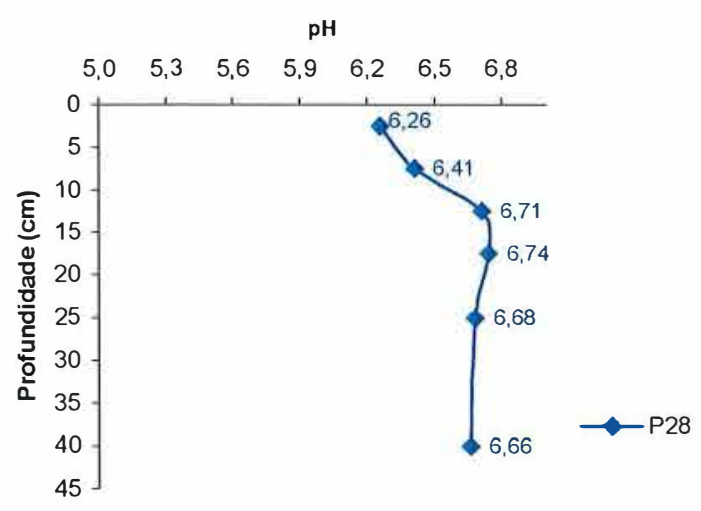

Manguezal do Rio Iriri

$\mathrm{pH}$

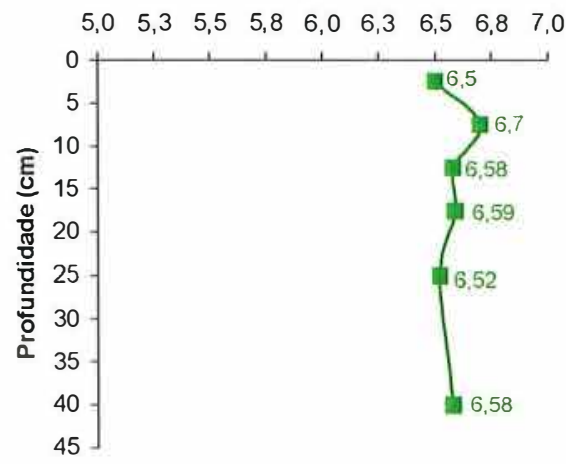

Manguezal do Rio Iriri

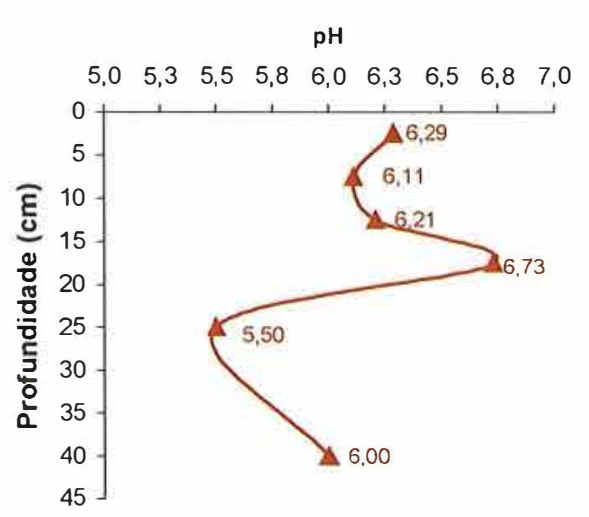

Manguezal do Rio Iriri

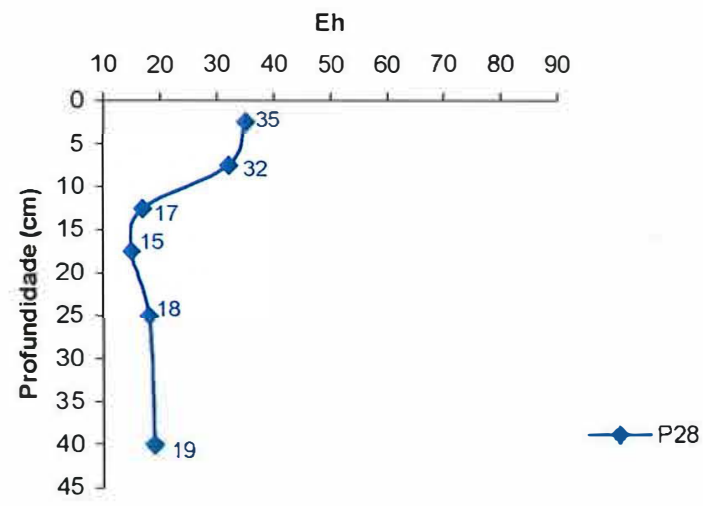

Manguezal do Rio Irirí

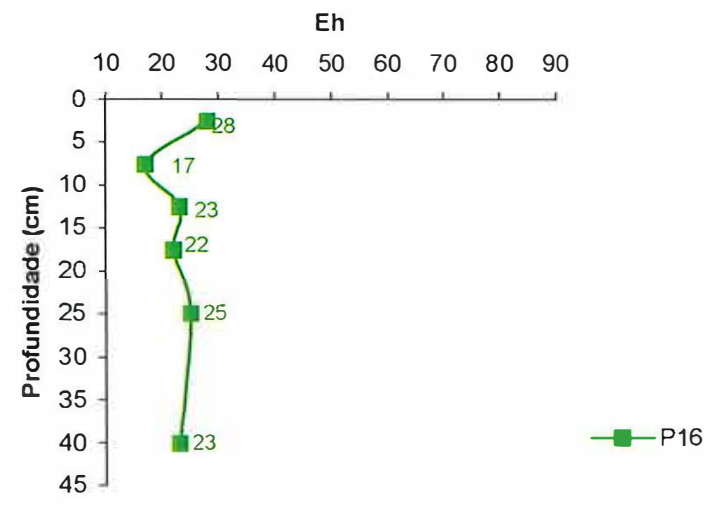

Manguezal do Rio Irirí

Eh

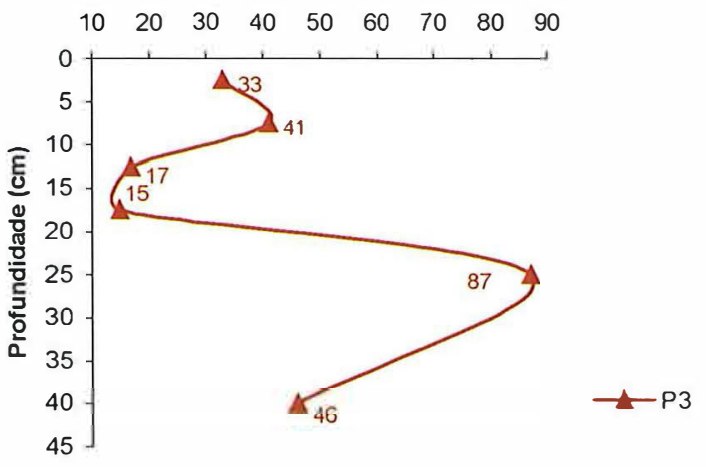

Figura 4.1 - Variação do pH e Eh em profundidade nos perfis do solo do manguezal do Rio Irirí 
Manguezal do Rio Crumahú

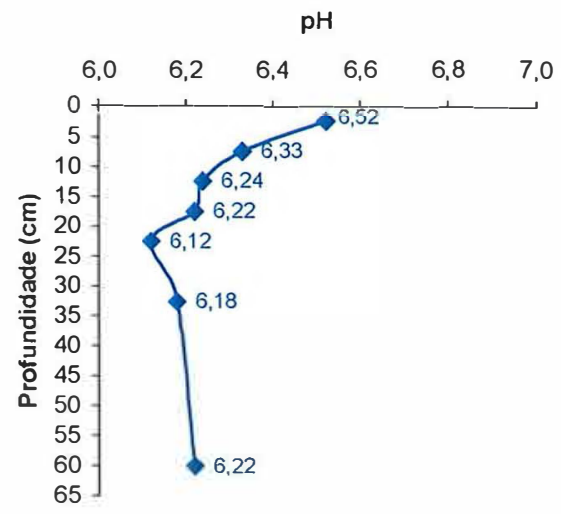

Manguezal do Rio Crumahú

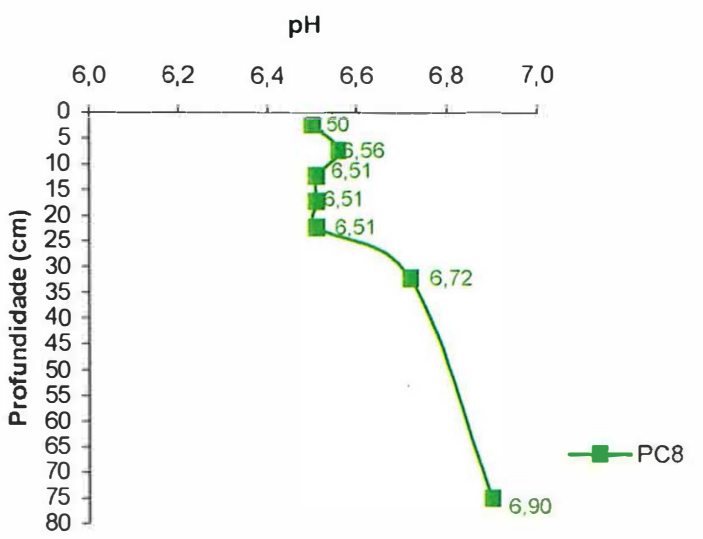

Manguezal do Rio Crumahú

$\mathrm{pH}$

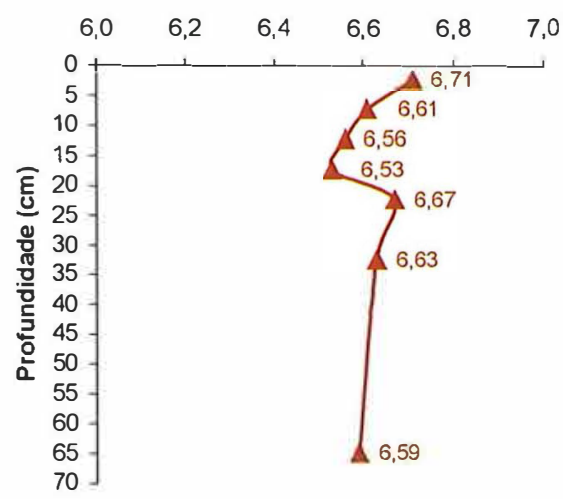

Manguezal do Rio Crumahú

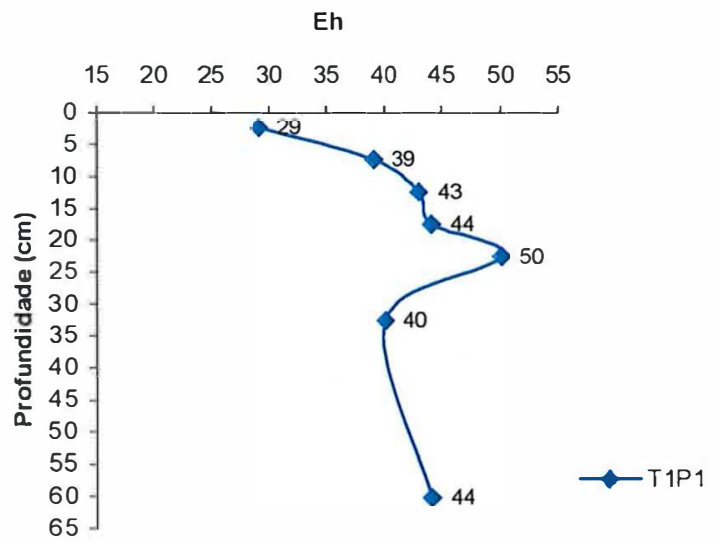

Manguezal do Rio Crumahú

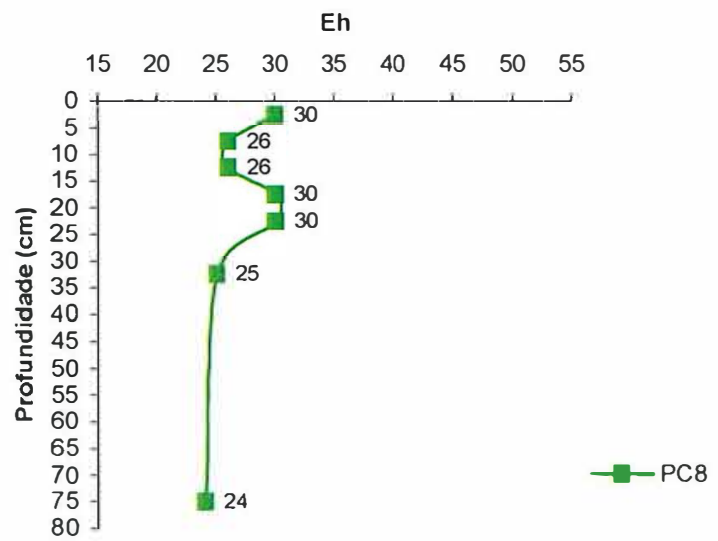

Manguezal do Rio Crumahú

Eh

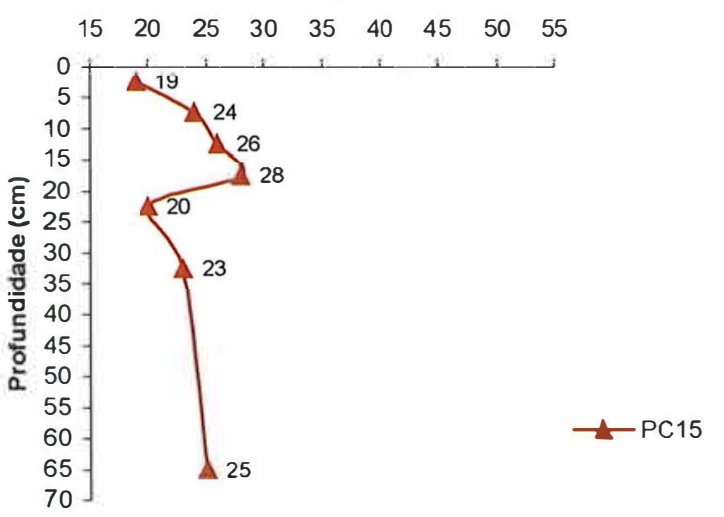

Figura 4.2 - Variação do pH e Eh em profundidade nos perfis do solo do manguezal do Rio Crumahú 
Manguezal do Canal da COSIPA

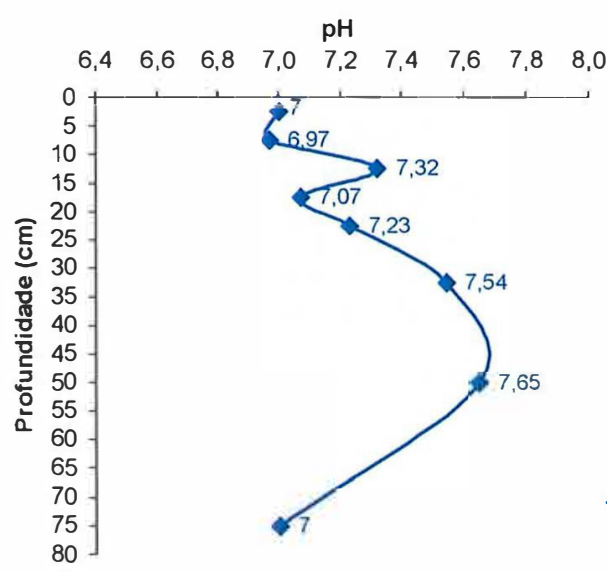

Manguezal do Canal da COSIPA

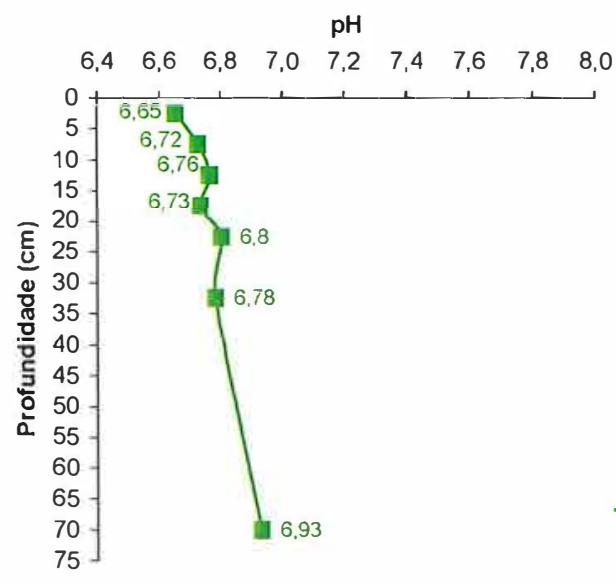

Manguezal do Canal da COSIPA

$\mathrm{pH}$

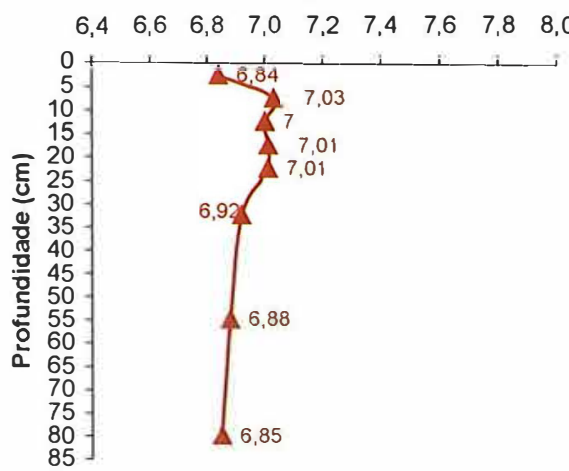

Manguezal do Canal da COSIPA

Eh

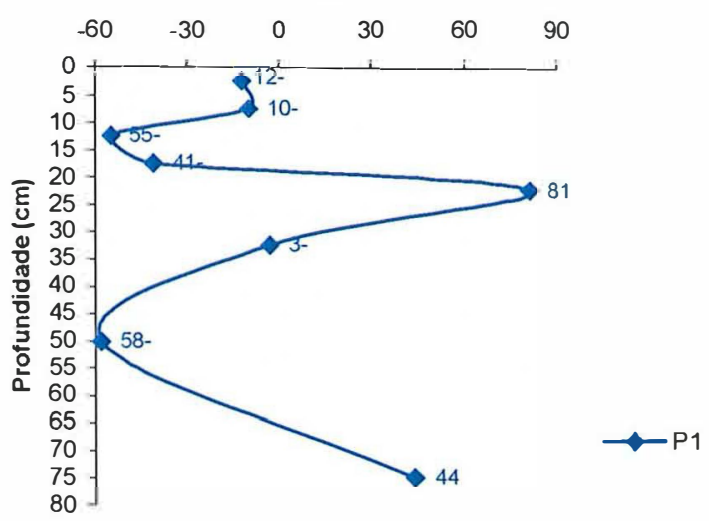

Manguezal do Canal da COSIPA

Eh

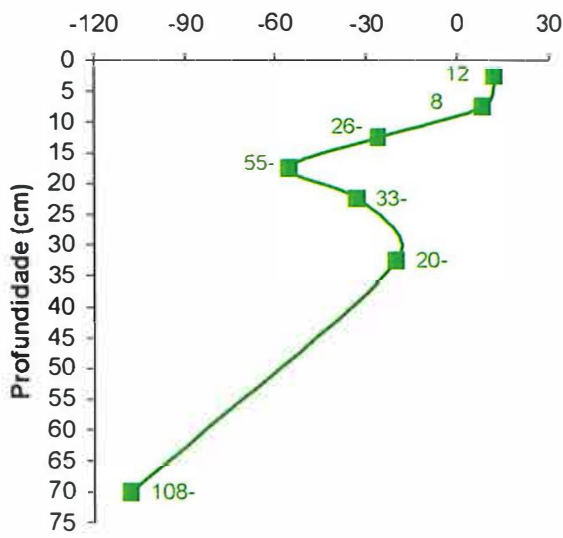

Manguezal do Canal da COSIPA

Eh

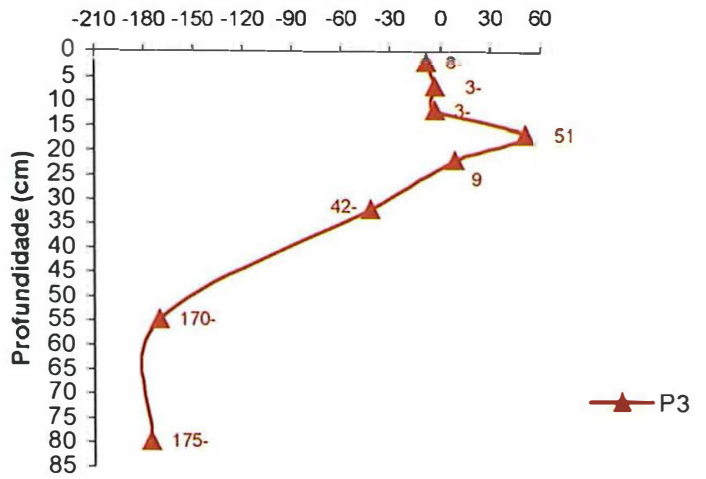

Figura 4.3 - Variação do pH e Eh em profundidade nos perfis do solo do manguezal do Canal da COSIPA 
Manguezal do Rio Cascalho

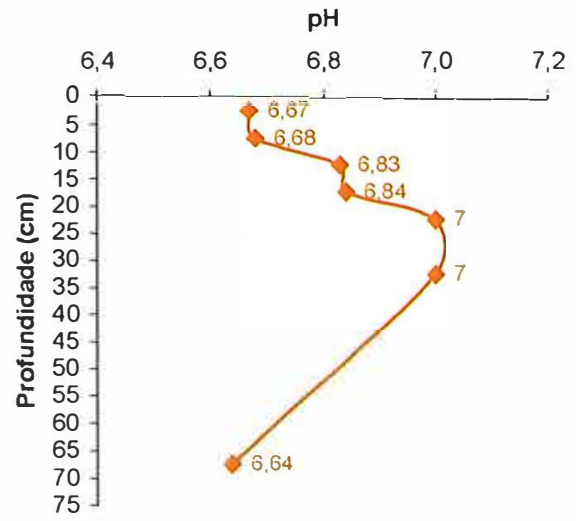

Manguezal do Rio Mariana

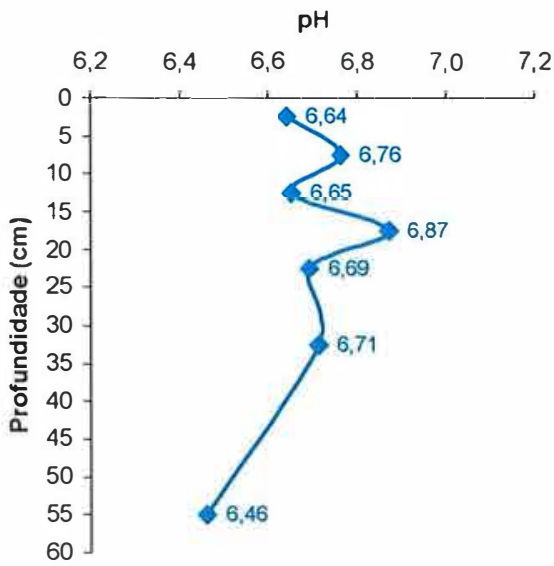

Manguezal do Rio Cascalho

Eh

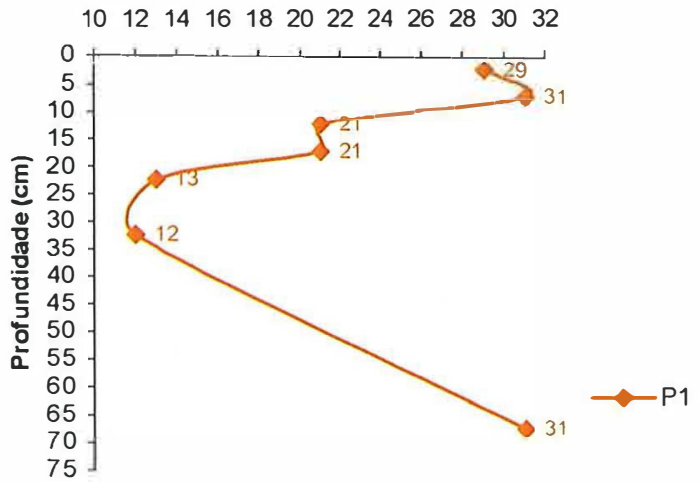

Manguezal do Rio Mariana

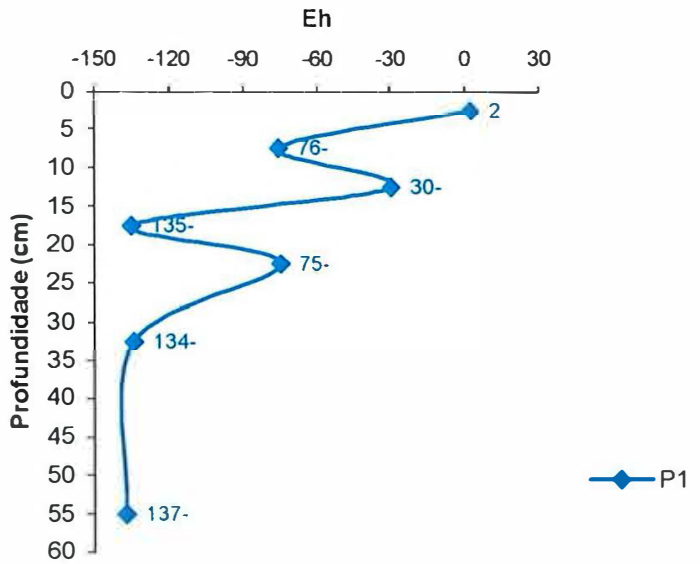

Figura 4.4 - Variação do pH e Eh em profundidade nos perfis dos solos dos manguezais dos Rios Cascalho e Mariana 
Manguezal da llha do Cardoso

$\mathrm{pH}$

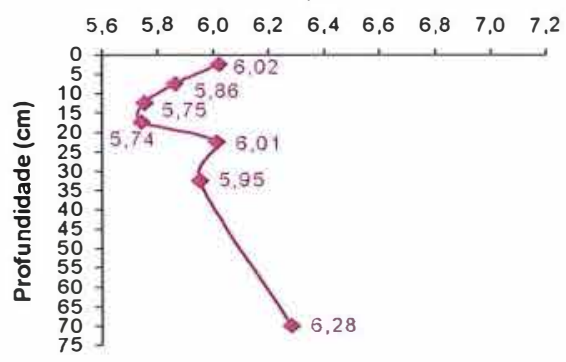

Manguezal da llha do Cardoso

$\mathrm{pH}$

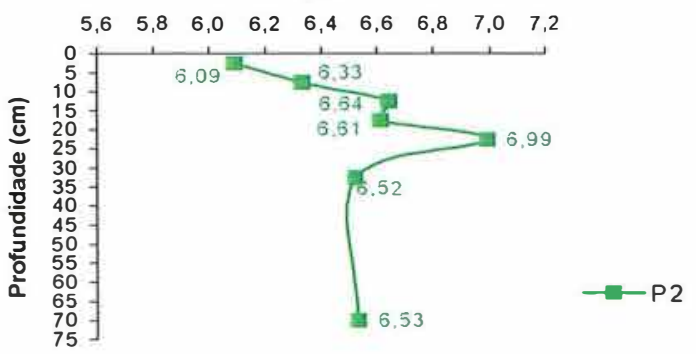

Manguezalda Ilha do Cardoso

$\mathrm{pH}$

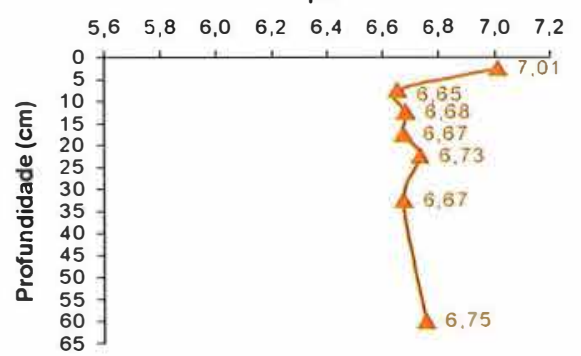

Manguezalda llha do Cardoso

$\mathrm{pH}$

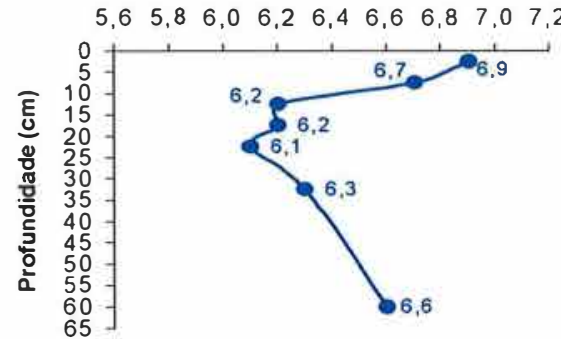

Manguezal da Ilha do Cardoso

Eh

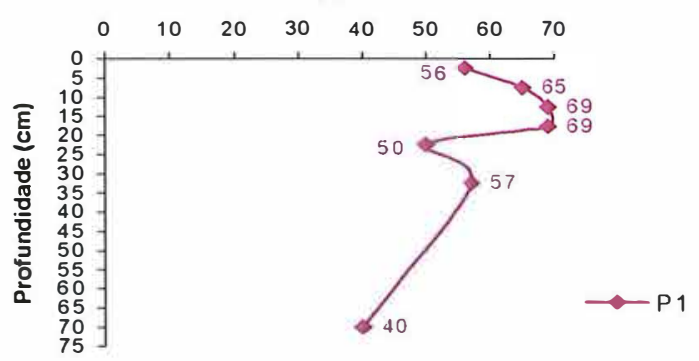

Manguezal da llha do Cardoso

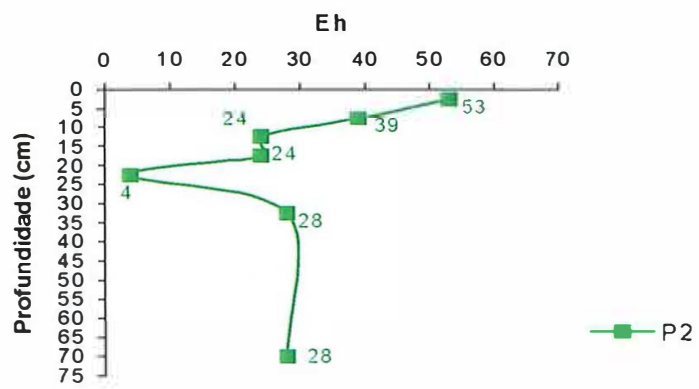

Manguezal da llha do Cardoso

Eh

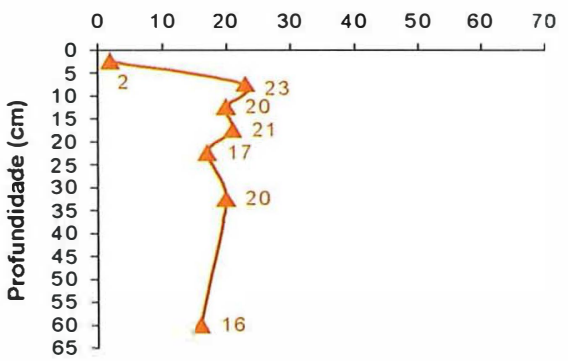

$\longrightarrow-P 3$

Eh

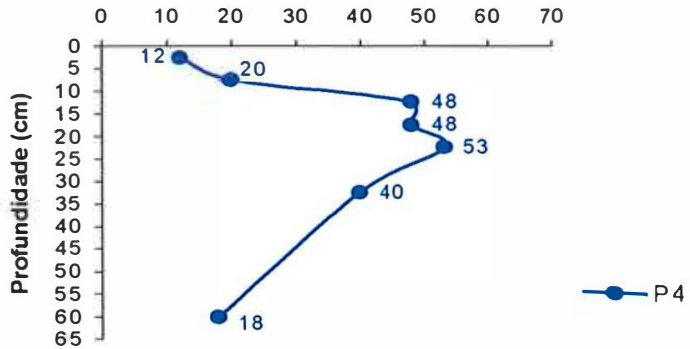

Figura 4.5 - Variação do pH e Eh em profundidade nos perfis do solo dos manguezais da Ilha do Cardoso 

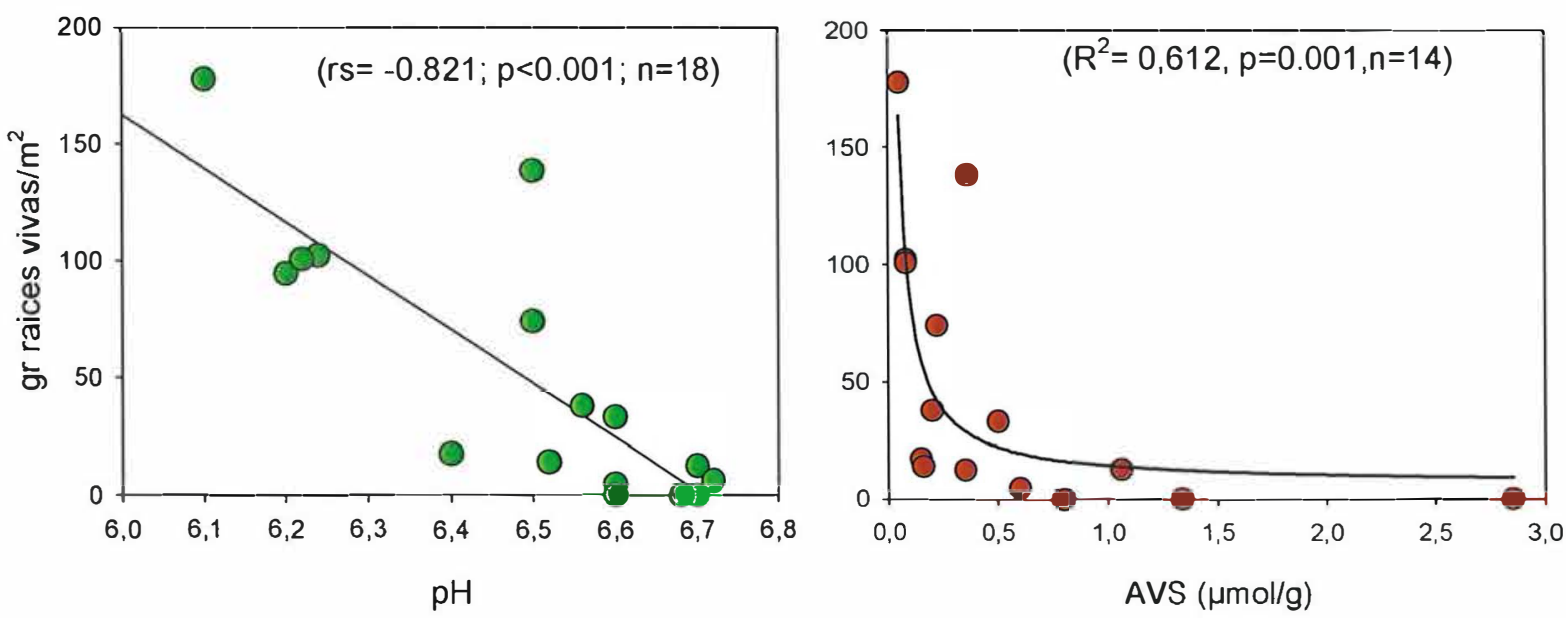

Figura 4.6 - Correlação entre pH e quantidade raízes vivas e entre AVS e quantidade de raízes vivas

\section{Carbono, nitrogênio e enxofre total.}

Os teores mais elevados de carbono total (Figuras 4.7 a 4.9 ) foram encontrados na parte mais superficial dos solos de manguezais. Em geral, existe uma tendência a diminuir o seu conteúdo com a profundidade, ainda que o decréscimo se apresente de modo irregular (Figura 4.7, Irirí P16 e Crumahú PC8; Figura 4.8, Cascalho P1 e Mariana P1; Figura 4.9, Ilha do Cardoso P1), provavelmente devido a irregular distribuição das raízes no solo com um máximo habitualmente situado aos $20-25 \mathrm{~cm}$ de profundidade. Outro motivo pode ser o aporte irregular de matéria orgânica ao solo, neste tipo de ambiente, devido à variação da sedimentação.

Os maiores teores oscilaram entre 30,2\% (Crumahú T1P1, 2,0cm) e $0,53 \%$ (Ilha do Cardoso P2, 0,5 cm).

Quanto ao nitrogênio, observa-se que os teores estão oscilando entre 1,6 (Crumahú T1P1, 3,5cm) e 0,04\% (COSIPA P3, $55 \mathrm{~cm}$ ) apresentando um comportamento semelhante ao $\mathrm{C}$ total. A correlação entre $\mathrm{C}$ total e o $\mathrm{N}$ total (Figura 4.10) foi altamente significativa $\left(r_{s}=0,971, p=0,001, n=150\right)$, indicando que a origem da maior parte do $N$ presente nestes solos é orgânica. O C e S total (Figura 4.10) também apresentaram uma 
correlação positiva e altamente significativa $\left(\mathrm{r}_{\mathrm{s}}=0,879, \mathrm{p}<0,001, \mathrm{n}=150\right)$. Porém, como se observa na Figura 4.10 existe um importante número de amostras que se desviam da linha da correlação e que apresentam altos conteúdos de $\mathrm{S}$ total (às vezes superior a 3\%). $\mathrm{Na}$ maior parte dos casos trata-se de amostras profundas que apresentam baixos conteúdos de $\mathrm{S}$ total e $\mathrm{C}$ total. Estes resultados indicam que além do $\mathrm{S}$ orgânico, existe nestes solos uma quantidade importante de $\mathrm{S}$ inorgânico que pode derivar-se dos processos de sulfato redução que acontece nestes solos. Esta idéia se apóia nos valores obtidos para o Eh, que indicam que a maior parte dos solos estudados apresentaram condições anóxicas com valores de Eh inferiores a $100 \mathrm{mV}$. Nestas condições os microrganismos do solo utilizam o sulfato como receptor de elétrons nos processos de oxidação da matéria orgânica (Patrick \& Jugsujinda, 1992). O produto final, termodinamicamente mais estável, é a pirita $\left(\mathrm{FeS}_{2}\right)$ que acaba acumulando-se nos solos. Entre outras formas inorgânicas do $\mathrm{S}$, podem estar também a mackinawita (FeS) ou a greigita $\left(\mathrm{Fe}_{3} \mathrm{~S}_{4}\right)$, entretanto estas são formas minoritárias.

A porcentagem de $\mathrm{S}$ total encontrada e a relação $\mathrm{C} / \mathrm{S}$ também estão de acordo com a anterior interpretação. Em solos naturais com condições, a porcentagem de $\mathrm{S}$ total raramente supera os 0,1\% e a relação C/S é da ordem de 200:1 (Raij, 1991; Havlin, 1999). Os resultados obtidos neste trabalho foram muito superiores para o conteúdo de $\mathrm{S}$ total, oscilando entre 0,1 e $4,7 \%$ e, pelo contrário, muito baixos para relação $\mathrm{C} / \mathrm{S}$, quase sempre inferiores a 20:1 e na maioria dos casos inferior a 10:1. Isto é devido, como já foi comentado, ao acúmulo nestes solos de quantidades importantes de $\mathrm{S}$ inorgânico (fundamentalmente pirita). 
P28 - Manguezal do Rio Irirí

$$
\text { C N S (\%) }
$$

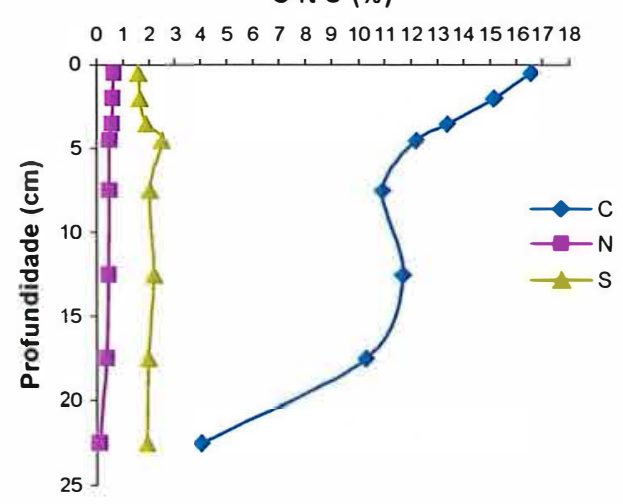

P16 - Manguezal do Rio Irirí

C N S (\%)

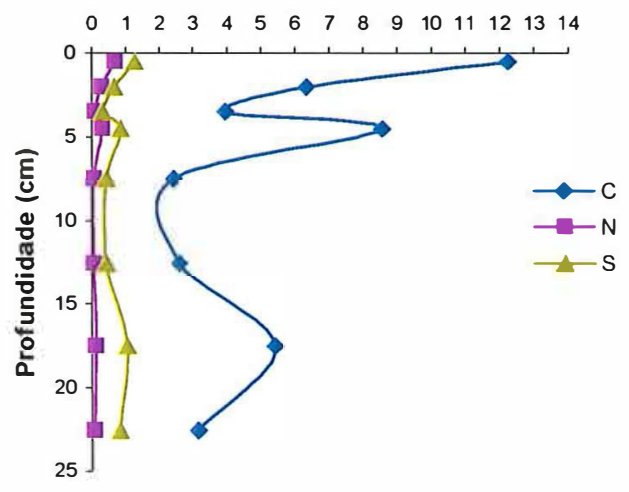

P3 - Manguezal do Rio Irirí

C N S (\%)

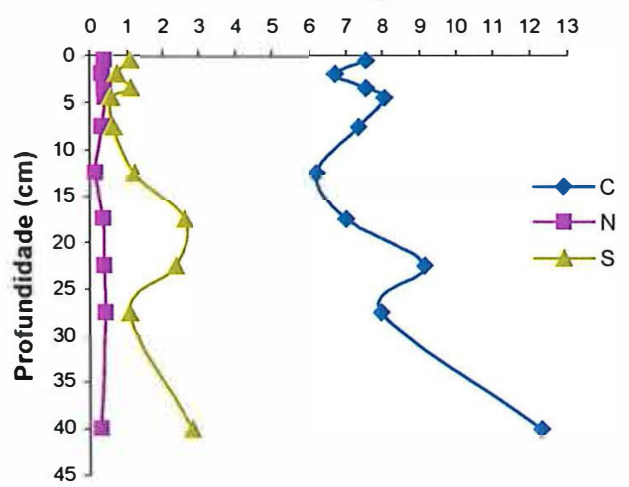

T1P1 - Manguezal do Rio Crumahú

C N S (\%)

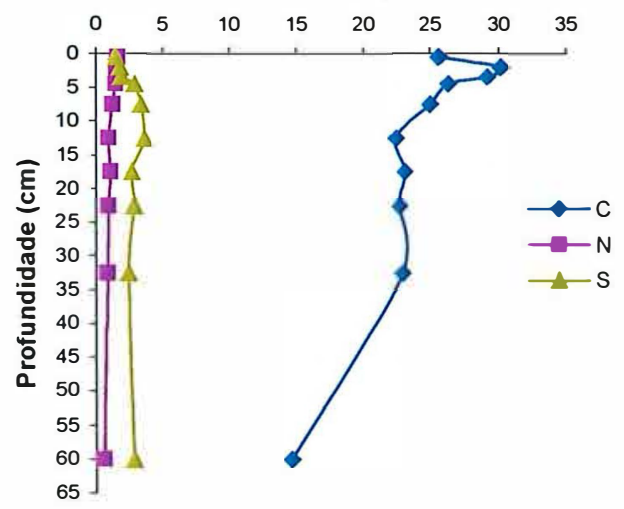

PC8 - Manguezal do Rio Crumahú

C N S (\%)

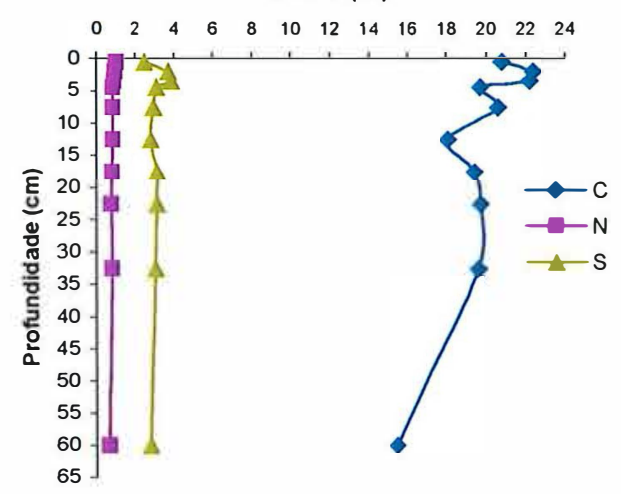

PC15 - Manguezal do Rio Crumahú

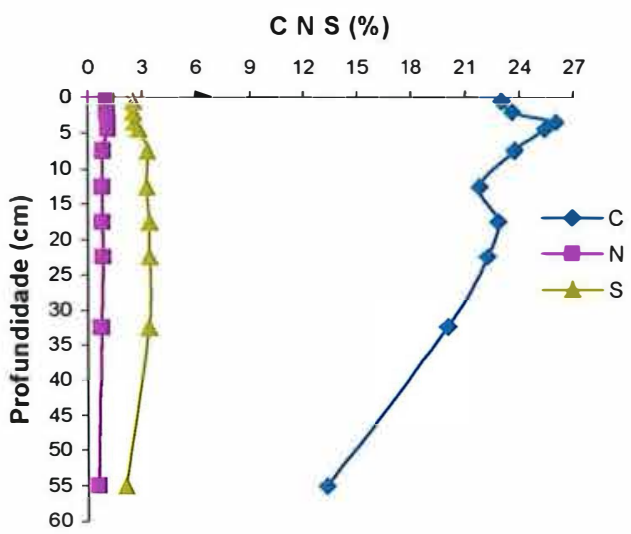

Figura 4.7 - Variação dos teores de $\mathrm{C}, \mathrm{N}$ e $\mathrm{S}$ total em relação à profundidade nos solos dos manguezais dos rios Irirí e Crumahú 
P1 - Manguezal do Canal da COSIPA

C N S $(\%)$

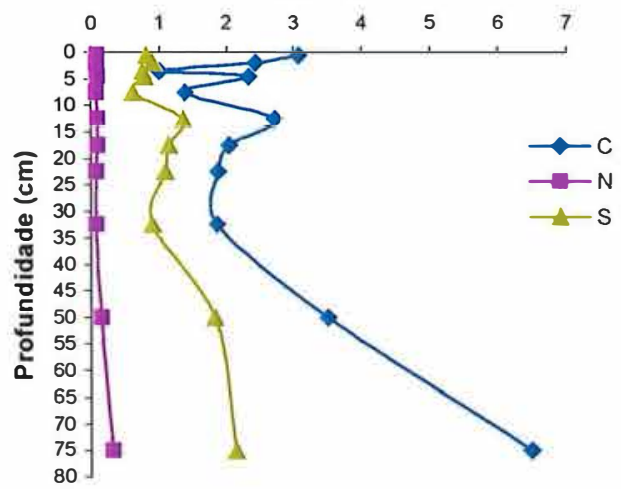

P2 - Manguezal do Canal da COSIPA

C N S (\%)

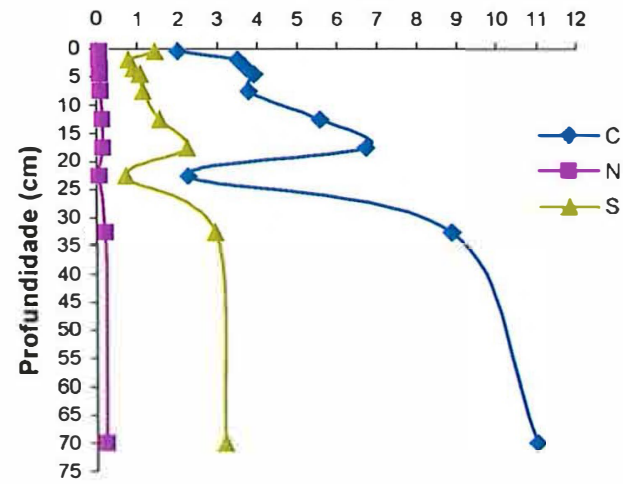

P3 - Manguezal do Canal da COSIPA

C N S $(\%)$

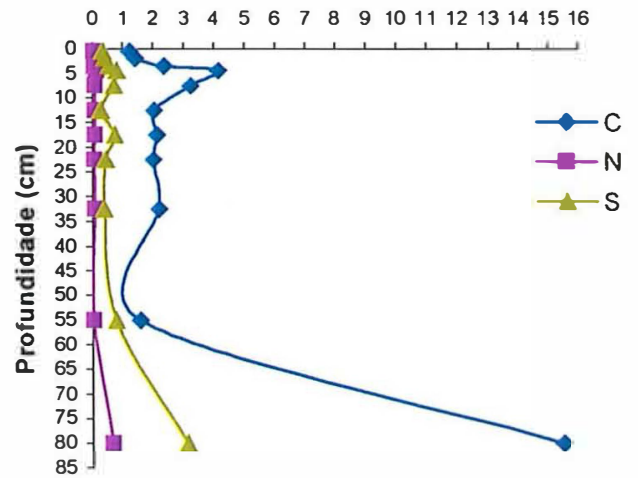

Manguezal do Rio Cascalho

C N S (\%)

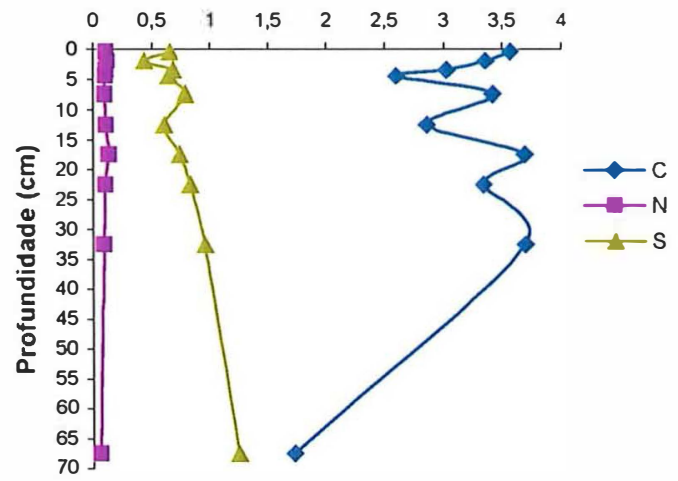

Manguezal do Rio Mariana

C N S (\%)

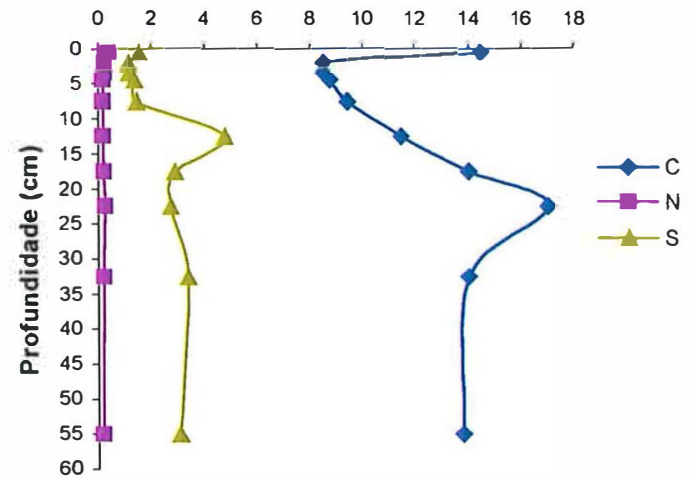

Figura 4.8 - Variação dos teores de $\mathrm{C}, \mathrm{N}$ e $\mathrm{S}$ total em relação à profundidade nos solos dos manguezais do canal da COSIPA e rios Cascalho e Mariana 
P1 - Manguezal da llha do Cardoso

C N S (\%)

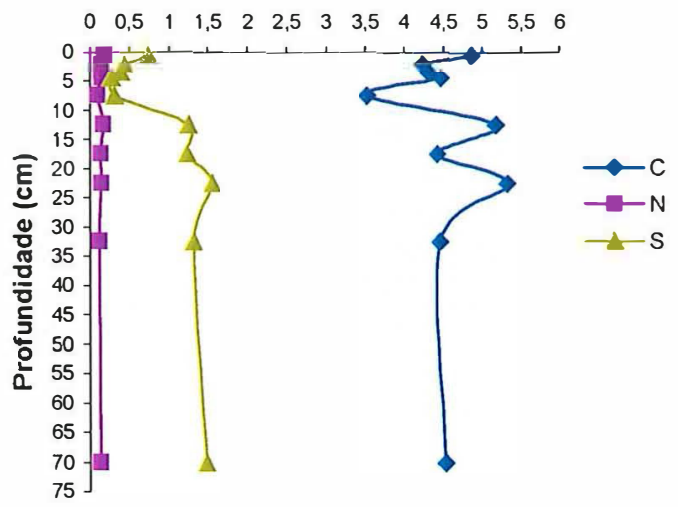

P3 - Manguezal da Ilha do Cardoso

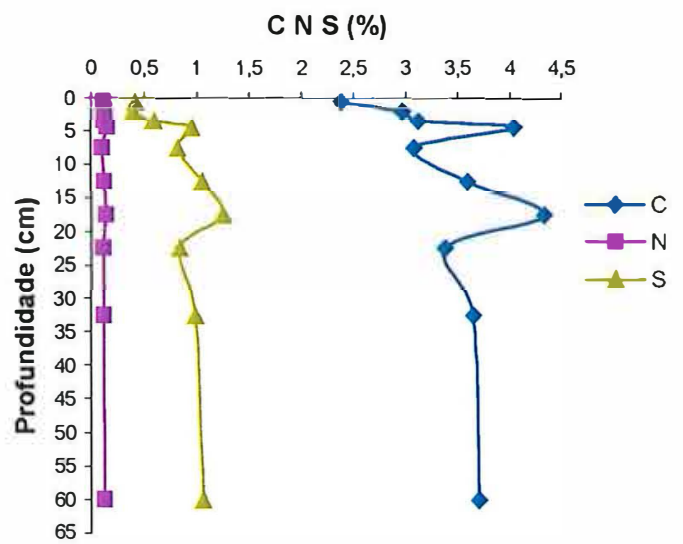

P2 - Manguezal da llha do Cardoso

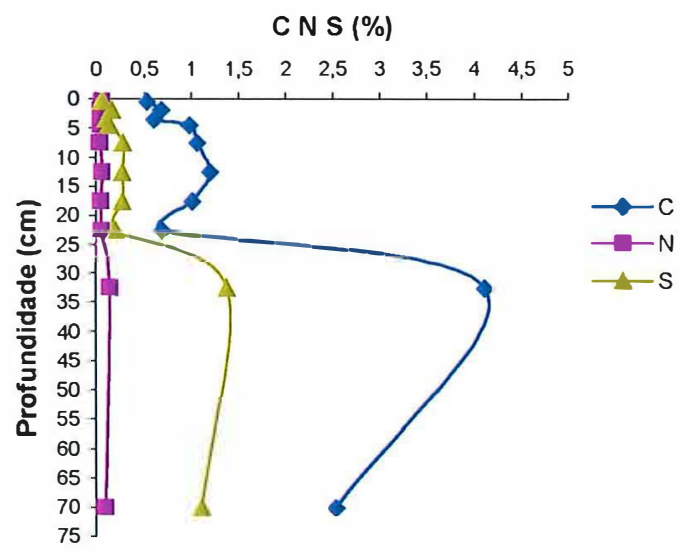

P4 - Manguezal da llha do Cardoso

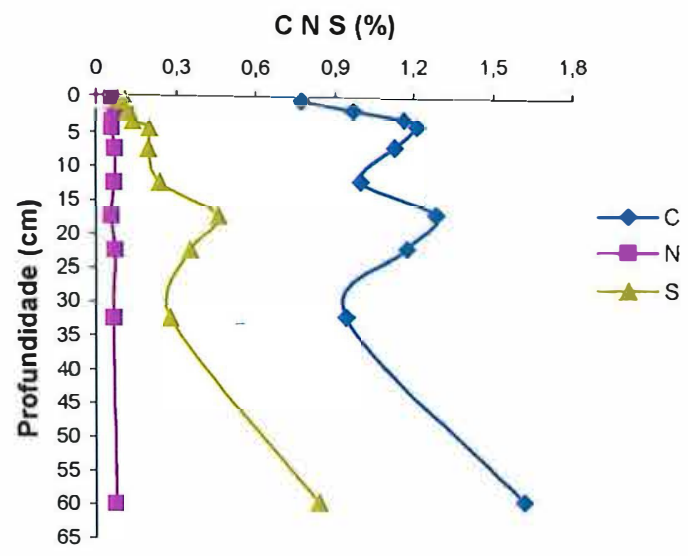

Figura 4.9 - Variação dos teores de $\mathrm{C}, \mathrm{N}$ e $\mathrm{S}$ total em relação à profundidade nos solos dos manguezais da Ilha do Cardoso 

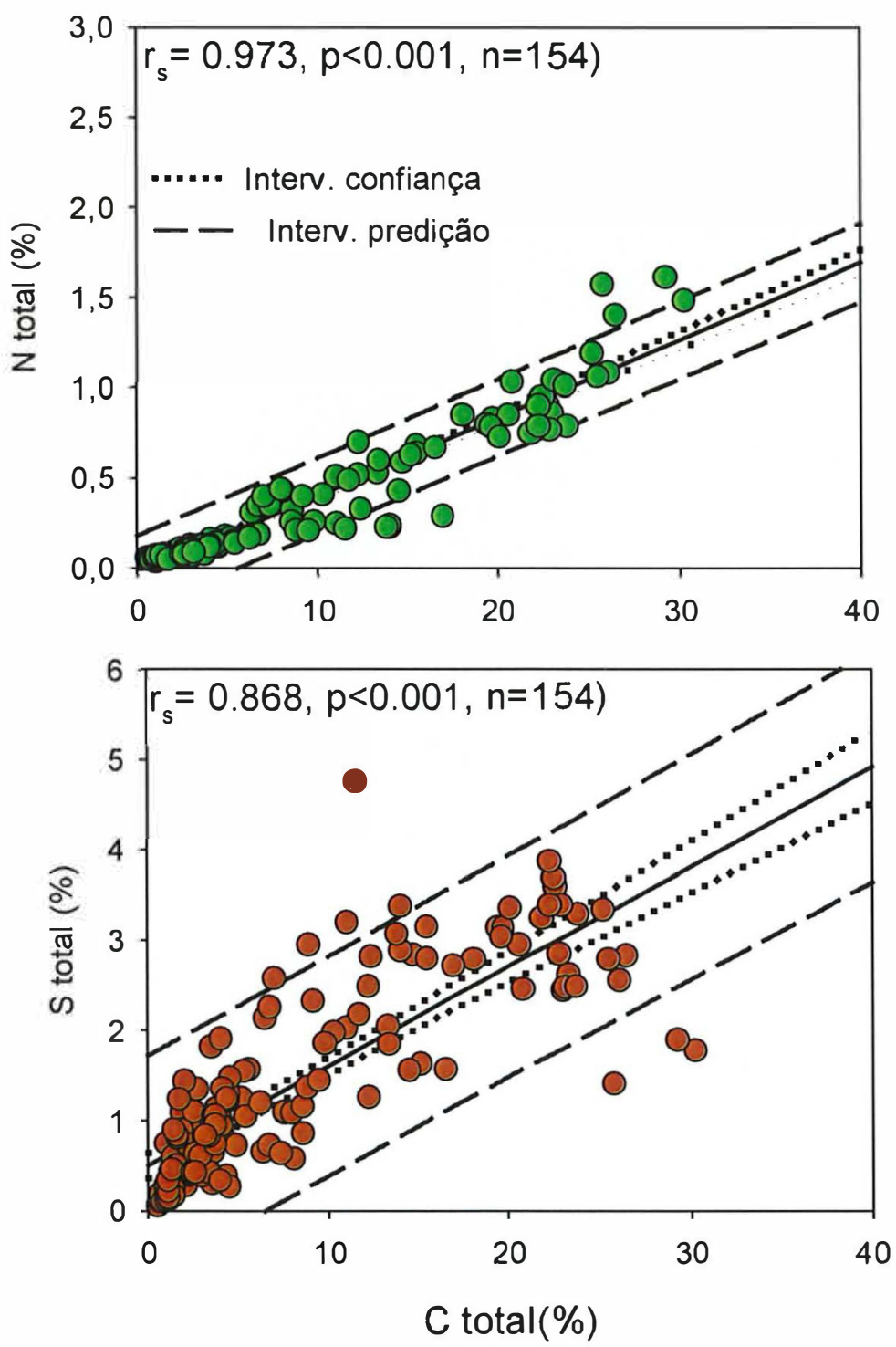

Figura 4.10 - Correlações entre $\mathrm{C}$ total e $\mathrm{N}$ total e $\mathrm{C}$ total e $\mathrm{S}$ total nos solos dos manguezais

\subsubsection{Marismas}

\section{Reação dos solos}

Na Tabela 4.1 são apresentadas as características gerais dos solos das marismas de Pontevedra e de Caldebarcos. Os resultados de carbono orgânico apresentaram uma variação elevada $(6,5-1,7 \%)$, correspondendo os valores mais baixos à parte mais 
profunda do solo. No entanto, deve-se destacar que o conteúdo de carbono orgânico varia de forma irregular com a profundidade. As diferenças nas condições redox foram especialmente significativas na parte superficial dos solos nos quais foram encontrados meios óxicos $(\mathrm{Eh}>300 \mathrm{mV})$. Em profundidade estes solos passam a ter condições subóxicas (Eh: 100-300 mV) e às vezes anóxicos $(\mathrm{Eh}<100 \mathrm{mV})$, aplicando o critério estabelecido por diferentes autores (p.ex. Patrick \& Mahapatra, 1968, Ponnamperuma, 1972). Estes resultados são próprios de solos de marisma alta, na qual se instala uma comunidade vegetal denominada Juncus maritimus, apresentando um sistema de rizomas muito bem desenvolvido que facilita a aeração do solo, conferindo-lhe condições óxicas em superfície. É necessário lembrar que a marisma alta somente fica plenamente inundada nas preamares vivas (ver Otero \& Macías, 2001). Uma situação similar à do juncal se encontra nos solos de borda de canal onde se instala a dicotiledônea Halimione portulacoides, espécie muito sensível à presença da água intersticial de $\mathrm{Mn}^{2+}$ e de $\mathrm{Fe}^{2+}$. Por isso, essa planta sempre busca os ambientes mais oxidantes da marisma alta que são precisamente as bordas de canal (Sánchez et al., 1998).

No entanto, os solos das marismas se caracterizam por apresentar uma ampla variação em suas condições redox. Assim sendo, na marisma baixa, que fica inundada por qualquer tipo de preamar, os solos podem apresentar já em superfície condições subóxicas ou inclusive anóxicas. Este é o caso dos solos das marismas de Ortigueira sobre os quais se desenvolve a espécie Zostera noltii $\left(\mathrm{Eh}_{0-5 \mathrm{~cm}}=67 \pm 44 \mathrm{mV}, \mathrm{Eh}_{20-25 \mathrm{~cm}}=-45\right.$ $\pm 33 \mathrm{mV}, \mathrm{n}=7)$ e Spartina maritima $\left(\mathrm{Eh}_{0-5 \mathrm{~cm}}=177 \pm 46 \mathrm{mV}, \mathrm{Eh}_{20-25 \mathrm{~cm}}=-15 \pm 66 \mathrm{mV}, \mathrm{n}=7\right)$. 
Tabela 4.1. Características gerais dos solos das marismas (nd: não determinado)

\begin{tabular}{lcccccccc}
\hline $\begin{array}{c}\text { Prof. } \\
(\mathrm{cm})\end{array}$ & \multicolumn{4}{c}{$\begin{array}{c}\text { Marisma de Caldebarcos } \\
\text { Marisma alta } \\
\text { Juncus maritimus }\end{array}$} & & \multicolumn{4}{c}{$\begin{array}{c}\text { Marisma de Pontevedra } \\
\text { Marisma alta } \\
\text { Juncus maritimus }\end{array}$} \\
\hline pH & Eh (mV) & $\mathbf{C ~ ( \% )}$ & $\mathbf{S ~ ( \% ) ~}$ & $\mathbf{p H}$ & $\mathbf{E h}(\mathbf{m V})$ & $\mathbf{C ~ ( \% )}$ & $\mathbf{S ~ ( \% )}$ \\
\hline $0-5$ & 5,9 & 384 & 6,5 & 0,32 & 6,1 & 367 & 5,3 & 0,25 \\
$5-10$ & 6,0 & 342 & 5,2 & nd & 6,0 & Nd & 6,0 & 0,32 \\
$10-15$ & 6,2 & nd & 6,1 & nd & 6,3 & Nd & 5,1 & 0,23 \\
$45-55$ & 6,4 & 324 & 3,1 & 0,30 & 7,0 & -76 & nd & nd \\
$90-100$ & nd & nd & 2,2 & 0,65 & 6,5 & 114 & 2,3 & 0,45 \\
$130-140$ & 7,3 & 114 & 1,9 & 1,2 & 6,8 & Nd & 1,7 & 0,68 \\
\hline
\end{tabular}

\begin{tabular}{|c|c|c|c|c|c|c|c|c|}
\hline \multirow[t]{2}{*}{$\begin{array}{l}\text { Prof. } \\
(\mathrm{cm})\end{array}$} & \multicolumn{4}{|c|}{$\begin{array}{c}\text { Marisma de Ortigueira } \\
\text { Marisma baixa } \\
\text { Zostera noltii }\end{array}$} & \multicolumn{4}{|c|}{$\begin{array}{l}\text { Marisma de Ortigueira } \\
\text { Marisma baixa } \\
\text { Spartina maritima }\end{array}$} \\
\hline & pH & Eh (mV) & $\mathrm{C}(\%)$ & S (\%) & $\mathbf{p H}$ & $\operatorname{Eh}(\mathrm{mV})$ & C (\%) & S (\%) \\
\hline $0-5$ & 7,2 & $67 \pm 44$ & nd & 1,05 & 6,6 & $177 \pm 46$ & nd & 0,59 \\
\hline $5-10$ & 7,3 & nd & nd & 1,39 & 7,2 & $\mathrm{Nd}$ & nd & 0,80 \\
\hline $10-15$ & 7,3 & nd & nd & 1,42 & 6,8 & $\mathrm{Nd}$ & nd & 1,19 \\
\hline $15-20$ & 7,4 & nd & nd & 1,57 & 6,9 & $\mathrm{Nd}$ & nd & 1,56 \\
\hline $20-25$ & 7,6 & $-45 \pm 33$ & nd & 1,60 & 7,1 & $-15 \pm 66$ & nd & 1,28 \\
\hline $25-30$ & nd & nd & nd & 1,47 & 7,4 & $\mathrm{Nd}$ & nd & 1,66 \\
\hline
\end{tabular}

\subsubsection{Sulfetos voláteis em meio ácido (AVS)}

\subsubsection{Manguezais}

A concentração obtida para os AVS nos solos de manguezais está ilustrada nas Figuras 4.11 a 4.13. Os resultados mostram amplas variações tanto espaciais como em profundidade. Nos solos de manguezais as concentrações médias oscilaram entre

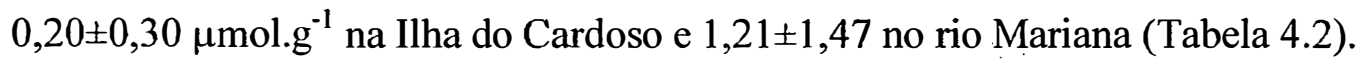


Tabela 4.2. Concentração média, máxima e mínima de AVS ( $\mu$ mol g $\left.{ }^{-1}\right)$ encontrada para os solos de manguezais e nas marismas

\begin{tabular}{lccc}
\hline \multicolumn{1}{c}{ Local } & Média \pm sd & Mínimo & Maximo \\
\hline rio Irirí & Manguezal & & \\
rio Crumahú & $0,31 \pm 0,48$ & 0,01 & 1,85 \\
canal da COSIPA & $0,99 \pm 1,24$ & 0,09 & 4,49 \\
rio Cascalho & $1,21 \pm 1,47$ & 0,02 & 7,60 \\
rio Mariana & $1,15 \pm 1,05$ & 0,07 & 3,84 \\
Ilha do Cardoso & $0,30 \pm 0,43$ & 0,01 & 1,48 \\
\hline & $0,20 \pm 0,30$ & 0,01 & 1,61 \\
\hline ría de Ortigueira - Zostera noltii & $2,94 \pm 2,62$ & 0,01 & \\
ría de Ortigueira - Spartina maritima & $0,12 \pm 0,14$ & 0,01 & 0,70 \\
ría Pontevedra - Juncus maritimus & $0,34 \pm 0,60$ & $<\mathrm{LD}$ & 2,41 \\
Caldebarcos - Juncus maritimus & $2,33 \pm 3,95$ & $<\mathrm{LD}$ & 10,58 \\
\hline
\end{tabular}

Os valores mais elevados foram encontrados nos solos daqueles manguezais que recebem maior quantidade de deposição de águas residuais. Provavelmente devido ao aporte de matéria orgânica aumentar a demanda de oxidantes, contribuindo para gerar condições mais redutoras no solo, o que favorece a atividade das bactérias redutoras do sulfato (BSR). Quanto a distribuição da concentração do AVS em profundidade não foi possível estabelecer um padrão claro comum à maior parte dos solos. Os resultados evidenciam que existem solos nos quais as concentrações mais elevadas apareceram em superfícies (p.ex. Figura 4.11: Irirí - P28, P16; Figura 4.12: Mariana - P1), enquanto que em outros casos estas se encontraram na parte mais profunda (Figura 4.11: Irirí - P3; Figura 4.13: Ilha do Cardoso - P2).

A presença de AVS no solo depende de vários fatores como a maior ou menor presença de ácidos orgânicos de baixo peso molecular que são o substrato sobre o que atuam as BSR, a atividade oxidante das plantas, o período do ano, a posição fisiográfica, a textura, etc. A correlação negativa encontrada entre a distribuição das raízes e a 
concentração de AVS evidencia a importância que têm a atividade das plantas sobre este parâmetro (Figura 4.6), atividade esta, que provavelmente se encontra governada pelas mudanças sazonais. Por isto, e pelo fato de que a amostragem tenha sido realizada em distintos momentos do ano, pode ser que parte do comportamento da distribuição dos AVS seja explicada pelas variações sazonais, deslocando os valores máximos em direção à superfície ou em profundidade, de acordo com as modificações das condições redox do solo. $\mathrm{O}$ fato de ter-se amostrado em diferentes momentos do ano impede, portanto, a elaboração de conclusões mais claras, exceto se forem feitos mais estudos que considerem as variações sazonais. 
Mangue do Rio Iriri - P28

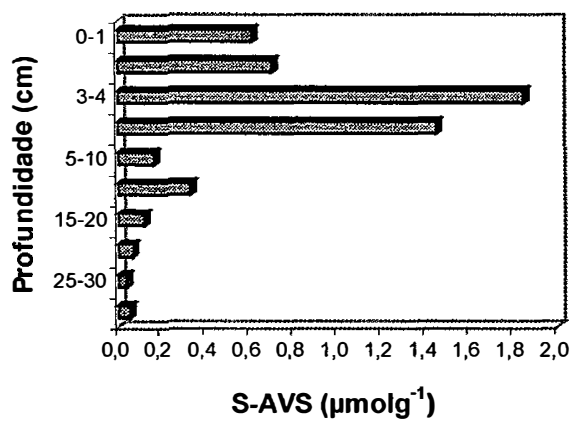

Mangue do Rio Iriri - P16

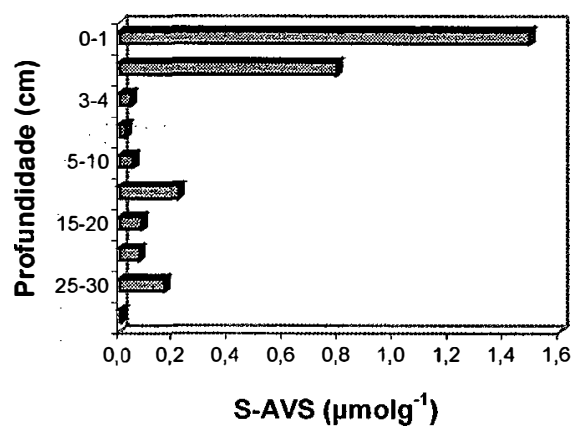

Mangue do Rio Iriri - P3

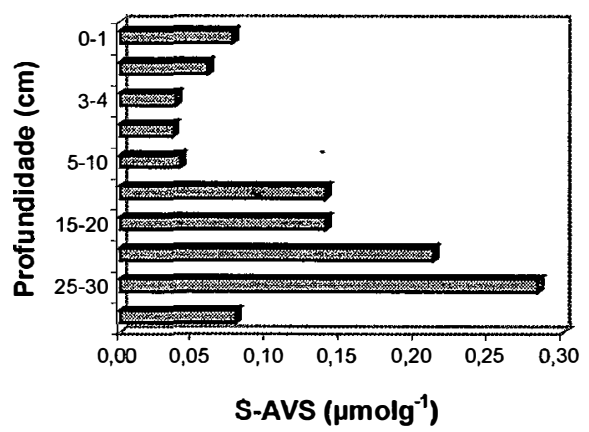

Mangue do Rio Crumahú - T1P1

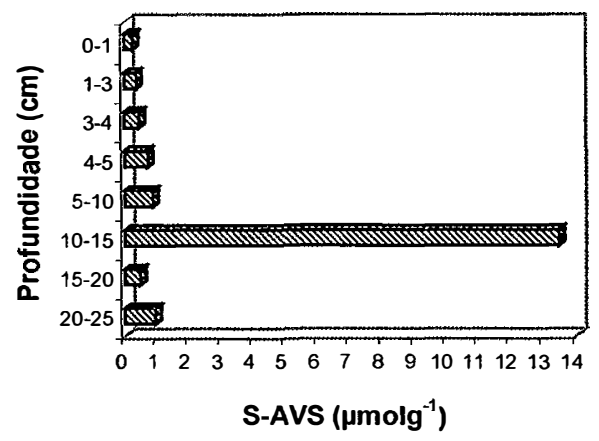

Mangue do Rio Crumahú - PC8

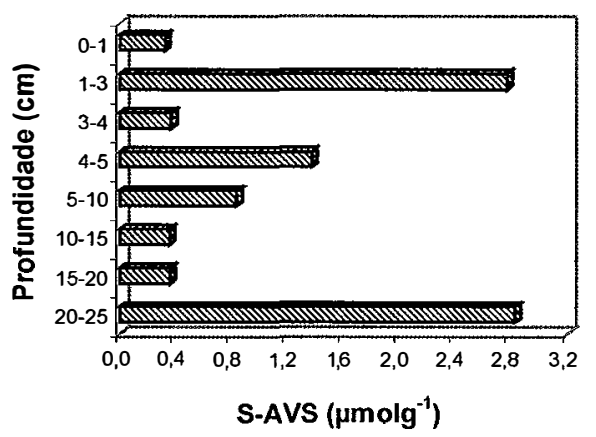

Mangue do Rio Crumahú - PC15

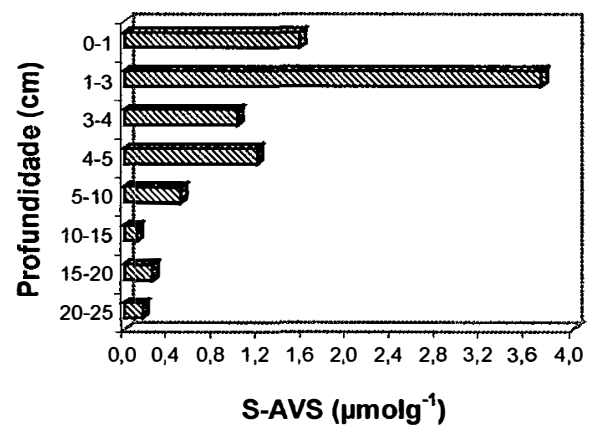

Figura 4.11 - Variação das concentrações médias dos sulfetos voláteis em meio ácido (AVS) em função da profundidade nos perfis dos solos dos manguezais dos rios Irirí e Crumahú 
Mangue do Canal da COSIPA - P1

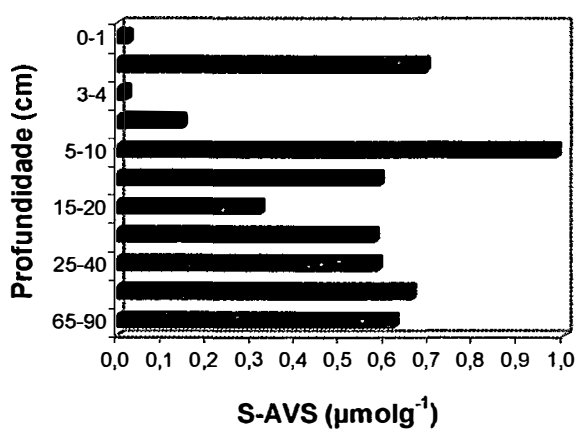

Mangue do Canal da COSIPA - P2

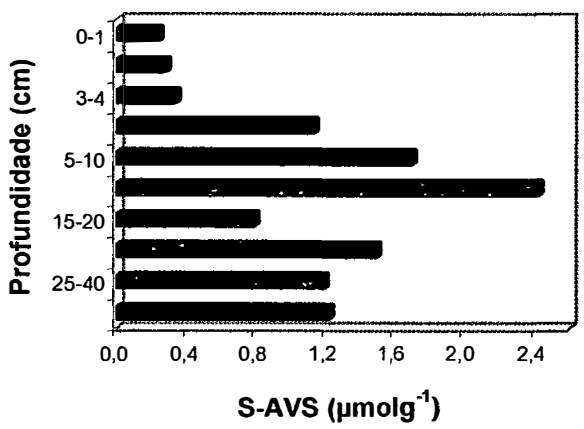

Mangue do Canal da COSIPA - P3

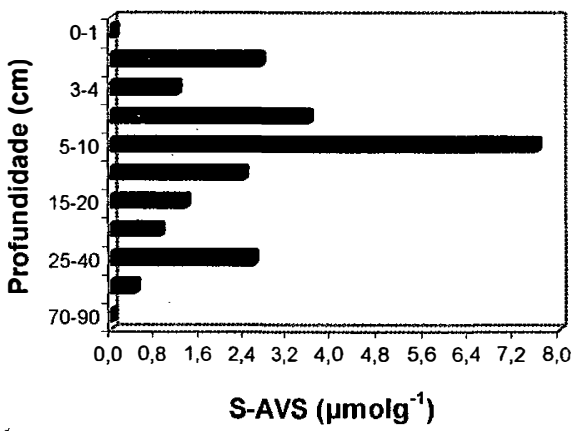

Mangue do Rio Cascalho - P1

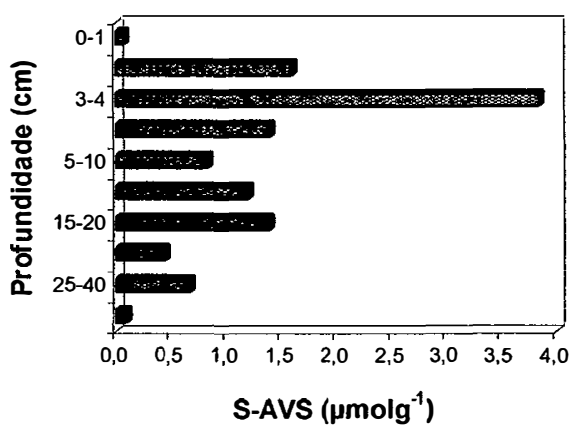

Mangue do Rio Mariana - P1

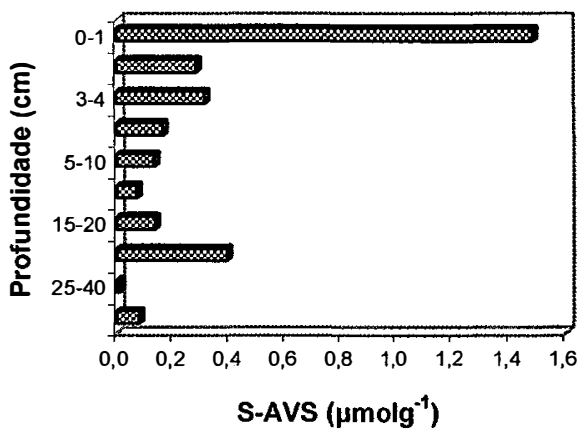

Figura 4.12 - Variação das concentrações médias dos sulfetos voláteis em meio ácido (AVS) em função da profundidade nos perfis dos solos dos manguezais do canal da COSIPA e dos rios Cascalho e Mariana 
Mangue da llha do Cardoso - P1

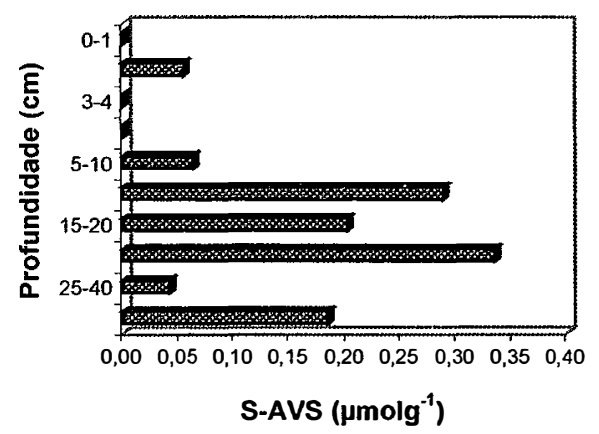

Mangue da IIha do Cardoso - P3

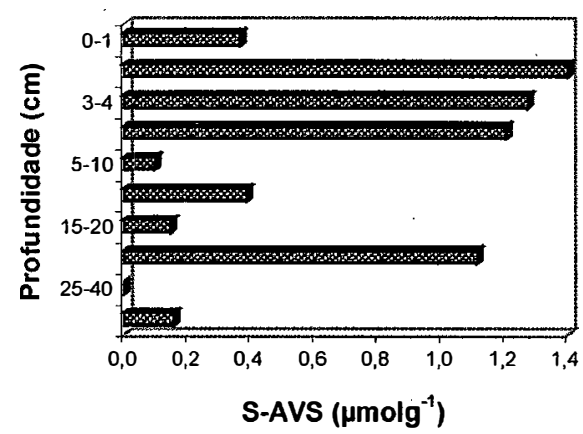

Mangue da Itha do Cardoso - P2

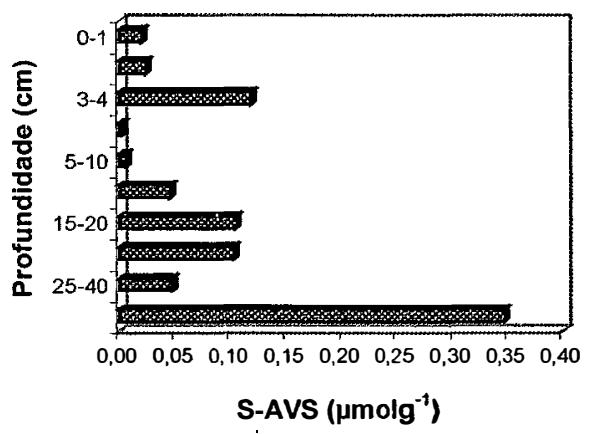

Mangue da llha do Cardoso - P4

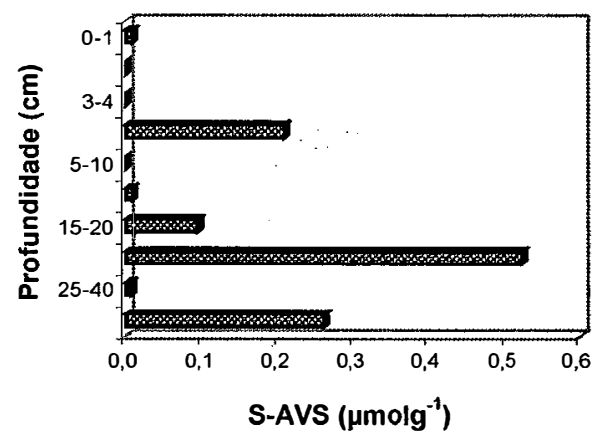

Figura 4.13 - Variação das concentrações médias dos sulfetos voláteis em meio ácido (AVS) em função da profundidade nos perfis dos solos dos manguezais da Ilha do Cardoso

\subsubsection{Marismas}

A distribuição dos AVS em solos das marismas das rías da Galicia já foi objeto de vários estudos (Otero \& Macías, 2002 a,b). Nestes trabalhos evidenciou-se que a concentração dos AVS no solo depende dos fatores anteriormente citados como, tipo de vegetação, posição fisiográfica, tipo de marisma e estação do ano. Os resultados encontrados nos solos considerados (Figura 4.14) obedecem a dois padrões de comportamento bastante claros. Na marisma baixa, com condições anóxicas em superfície, a concentração máxima se encontra na parte superficial do solo, onde a atividade das BSR é maior devido à presença de ácidos orgânicos segregados pelas raízes das plantas. Além disso, em profundidade, onde as condições são 
permanentemente anóxicas, o AVS pode ser consumido no processo de síntese da pirita, de acordo com a seguinte equação (Richard \& Luther, 1997):

$$
\mathrm{FeS}+\mathrm{H}_{2} \mathrm{~S} \rightarrow \mathrm{FeS}_{2}+\mathrm{H}_{2}
$$

$\mathrm{Na}$ marisma alta, o máximo de concentração dos AVS se desloca em profundidade já que somente abaixo dos $50-70 \mathrm{~cm}$ são alcançadas condições anóxicas. 

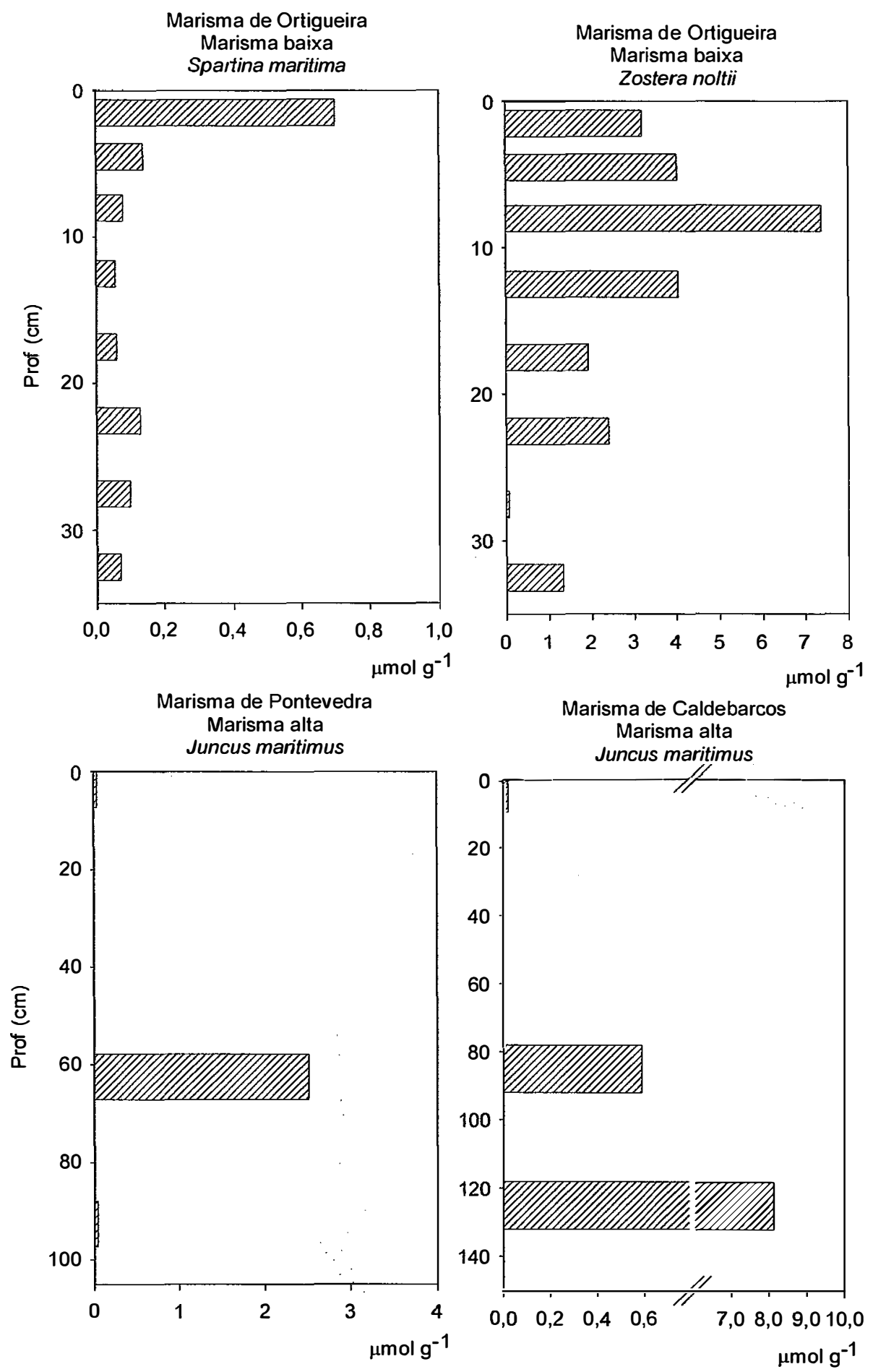

Figura 4.14 - Variação da concentração média dos sulfetos voláteis em meio ácido (AVS) em função da profundidade nos solos das marismas das rías da Galícia 


\subsubsection{Conteúdo total dos elementos traço}

Nas Tabelas 4.3 a 4.6 encontram-se os teores totais dos elementos traço analisados nos solos dos manguezais e das Marismas em comparação aos valores de referência de qualidade, alerta e intervenção estipulados pela CETESB (2001a) e TEL e PEL estabelecidos pela agência ambiental canadense (Enviroment Canada, 1999).

$\mathrm{O}$ valor de referência indica o nível de qualidade para um solo considerado limpo; o valor de alerta, indica a alteração da qualidade natural dos solos e quando excedido, a área será declarada poluída; e o valor de intervenção, indica a existência de contaminação do solo. Quando excedido, a área será declarada contaminada, pois existe risco potencial de efeito deletério sobre a saúde humana. TEL ("Thershold Effect Level") indica a concentração abaixo da qual não são esperados efeitos adversos sobre organismos aquáticos e PEL ("Probable Effect Level") indica a concentração acima da qual são esperados efeitos adversos severos sobre organismos aquáticos (CETESB, 2001b).

\subsubsection{Manguezais}

Com base nos valores orientadores estabelecidos pela CETESB (2001), os dados obtidos para cada elemento e apresentados nas Tabelas abaixo serão avaliados isoladamente.

\section{Arsênio}

Nos solos das áreas de manguezais em estudo, o arsênio apresenta valores acima do estabelecido como referência para um solo limpo $\left(3,5 \mathrm{mg} \cdot \mathrm{kg}^{-1}\right)$ para os manguezais do rio Irirí (Tabela 4.3), Cascalho; Mariana, canal da COSIPA (Tabela 4.4) e Ilha do Cardoso (Tabela 4.5), indicando que a qualidade destes solos está afetada. Ainda na Tabela 4.3, observa-se que para o solo do manguezal do Crumahú os valores apresentados ultrapassam os estabelecidos como alerta $\left(15 \mathrm{mg} \cdot \mathrm{kg}^{-1}\right)$, indicando certo grau de poluição. 


\section{Bário}

O bário apresenta valores acima do estabelecido como alerta (150 mg. $\left.\mathrm{kg}^{-1}\right)$ para os manguezais do rio Crumahú (Tabela 4.3), Mariana (Tabela 4.4) e Ilha do Cardoso P4 (Tabela 4.5), sendo que os maiores valores apresentados referem-se aos solos do Crumahú que variaram de 286 a $369 \mathrm{mg} \cdot \mathrm{kg}^{-1}$, indicando que este solo está poluído por este elemento.

Através das Tabelas 4.3, 4.4, e 4.5, observa-se que para os solos do manguezal do Irirí P28 (550 a 804 mg. $\mathrm{kg}^{-1}$ ), do Cascalho (608 a 706 mg.kg ${ }^{-1}$ ), do canal da COSIPA P1 (555 a 636 mg. $\mathrm{kg}^{-1}$ ) e da Ilha do Cardoso P1 (763 a 852 mg. $\mathrm{kg}^{-1}$ )os valores apresentados ultrapassam os estabelecidos para intervenção (400 a $700 \mathrm{mg} \cdot \mathrm{kg}^{-1}$ ), indicando certo grau de contaminação.

\section{Chumbo}

Os resultados de chumbo obtidos para os solos estudados indicam que os manguezais do Crumahú, Irirí (Tabela 4.3), COSIPA (Tabela 4.4) e Ilha do Cardoso P1 (Tabela 4.5), comparados com o valor de referência $\left(17 \mathrm{mg} \cdot \mathrm{kg}^{-1}\right)$, estão com a qualidade afetada.

\section{Cobalto}

Através das Tabelas 4.3, 4.4, e 4.5, verifica-se que os`valores obtidos para o cobalto nos solos dos manguezais estudados apresentam-se abaixo do estabelecido como referência para solos de boa qualidade $\left(13 \mathrm{mg} \cdot \mathrm{kg}^{-1}\right)$.

\section{Cobre}

Assim como para o cobalto, os resultados obtidos para o cobre (Tabelas 4.3, 4.4, e 4.5) nos solos dos manguezais estudados, apresentam-se abaixo do estabelecido como referência (35 mg. $\left.\mathrm{kg}^{-1}\right)$ indicando a integridade da qualidade dos mesmos. 
Tabela 4.3. Teores de V, Cr, Co, Ni, Cu, Zn, As, Ba, $\mathrm{Pb}$ e Mo $\left(\mathrm{mg}^{\circ} \mathrm{kg}^{-1}\right)$ das áreas dos manguezais do Rio Irirí, Rio Crumahú e Valores Orientadores para a qualidade dos solos no Estado de São Paulo (CETESB, 2001a)

\begin{tabular}{|c|c|c|c|c|c|c|c|c|c|c|c|c|}
\hline \multirow{2}{*}{ Áreas } & \multirow{2}{*}{ Perfis } & \multirow{2}{*}{ Profundidade $(\mathrm{cm})$} & \multicolumn{10}{|c|}{ Elementos Químicos Analisados $\left(\mathrm{mg}^{\mathrm{kg}} \mathrm{kg}^{-1}\right)$} \\
\hline & & & $\mathbf{v}$ & $\mathrm{Cr}$ & Co & $\mathbf{N i}$ & $\mathrm{Cu}$ & Zn & As & $\mathbf{B a}$ & $\mathbf{P b}$ & Mo \\
\hline \multirow{7}{*}{ 导 } & \multirow{4}{*}{ T1P1 } & 2,5 & 57,60 & 43,60 & 9,70 & 22,30 & 23,00 & 120,20 & 29,00 & 0,00 & 44,70 & 24,46 \\
\hline & & 7,5 & 62,10 & 46,90 & 14,00 & 25,80 & 18,90 & 110,40 & 24,00 & 4,89 & 46,80 & 22,19 \\
\hline & & 33,5 & 81,40 & 56,30 & 7,10 & 22,10 & 9,19 & 49,60 & 26,00 & 116,00 & 24,00 & 29,15 \\
\hline & & 55,0 & 94,00 & 71,80 & 9,50 & 25,30 & 11,00 & 75,75 & 14,00 & 369,00 & 29,70 & 17,25 \\
\hline & \multirow{3}{*}{ PC15 } & 2,5 & 81,90 & 48,90 & 11,00 & 26,00 & 14,60 & 96,51 & 27,00 & 0,00 & 29,70 & 35,52 \\
\hline & & 7,5 & 76,10 & 53,10 & 13,50 & 27,60 & 13,20 & 89,83 & 25,00 & 0,00 & 31,60 & 42,61 \\
\hline & & 55,0 & 105,00 & 67,10 & 11,00 & 26,00 & 14,40 & 90,37 & 0,00 & 286,00 & 28,10 & 30,94 \\
\hline \multirow{8}{*}{\multicolumn{2}{|c|}{ 范 }} & 2,5 & 77,80 & 70,10 & 12,40 & 19,80 & 11,30 & 103,80 & 0,00 & 549,00 & 33,60 & 10,40 \\
\hline & & 7,5 & 73,30 & 54,40 & 7,50 & 14,00 & 3,31 & 51,18 & 0,00 & 803,60 & 24,30 & 13,90 \\
\hline & & 22,5 & 73,40 & 50,40 & 7,80 & 17,20 & 5,71 & 59,06 & 0,00 & 774,40 & 23,80 & 12,20 \\
\hline & & 32,5 & - & 53,75 & - & 7,47 & 6,56 & 49,85 & 10,77 & - & 14,42 & - \\
\hline & & 2,0 & - & 41,33 & - & 13,65 & 3,88 & 37,78 & 8,29 & - & 9,47 & - \\
\hline & & 12,5 & - & 38,29 & - & 9,41 & 3,08 & 23,84 & 2,97 & - & 7,83 & - \\
\hline & & 17,5 & - & 41,94 & - & 11,21 & 1,95 & 28,40 & 4,41 & - & 8,94 & - \\
\hline & & 45,0 & $\cdot$ & 57,30 & - & 7,15 & 3,11 & 58,78 & 9,00 & - & 8,88 & - \\
\hline \multirow{6}{*}{\multicolumn{2}{|c|}{ P3 }} & 0,5 & - & 97,78 & - & 23,25 & 11,63 & 81,67 & 13,62 & - & 19,19 & - \\
\hline & & 4,5 & - & 97,45 & - & 16,12 & 15,50 & 67,76 & 9,18 & - & 17,94 & - \\
\hline & & 7,5 & $\therefore$ & 77,26 & - & 18,13 & 6,25 & 58,24 & 5,96 & - & 15,08 & - \\
\hline & & 17,5 & - & 84,20 & - & 27,39 & 11,23 & 88,95 & 11,63 & - & 18,70 & - \\
\hline & & 32,5 & - & 77,87 & - & 21,97 & 10,74 & 68,02 & 15,64 & - & 13,10 & - \\
\hline & & 45,0 & - & 73,41 & - & 26,97 & 7,70 & 63,25 & 12,21 & - & 9,95 & - \\
\hline \multirow{4}{*}{\multicolumn{2}{|c|}{$\begin{array}{l}\text { Valores orientadores } \\
\text { para a qualidade dos } \\
\text { solos }\left(\mathrm{mg}^{\left.-\mathrm{Kg}^{-1}\right)} \text { no }\right. \\
\text { Estado de São Paulo } \\
\text { (CETESB, 2001) }\end{array}$}} & Referência & 275,00 & 40 & 13 & 13 & 35 & 60 & 3,50 & 75 & 17 & $<25$ \\
\hline & & Alerta & $x$ & 75 & 25 & 30 & 60 & 300 & 15 & 150 & 100 & 30 \\
\hline & & & $\mathrm{x}$ & $700^{*}$ & $80^{*}$ & $200^{*}$ & $500^{*}$ & $1000^{*}$ & $50^{*}$ & $400^{*}$ & $350^{*}$ & $100^{*}$ \\
\hline & & $\begin{array}{c}\text { Residencial** e } \\
\text { Industrial }^{* *}\end{array}$ & $x$ & $1000^{* *}$ & $100^{*}$ & $300 * *$ & $700^{* *}$ & $1500^{* *}$ & $100^{* *}$ & $700^{* *}$ & $1200^{* *}$ & $120^{* *}$ \\
\hline
\end{tabular}


Tabela 4.4. Teores de V, Cr, Co, Ni, Cu, Zn, As, Ba, $\mathrm{Pb}$ e Mo (mg.kg $\left.{ }^{-1}\right)$ das áreas dos manguezais do canal da COSIPA, Rio Cascalho, Rio Mariana e Valores Orientadores para a qualidade dos solos no Estado de São Paulo (CETESB,2001a)

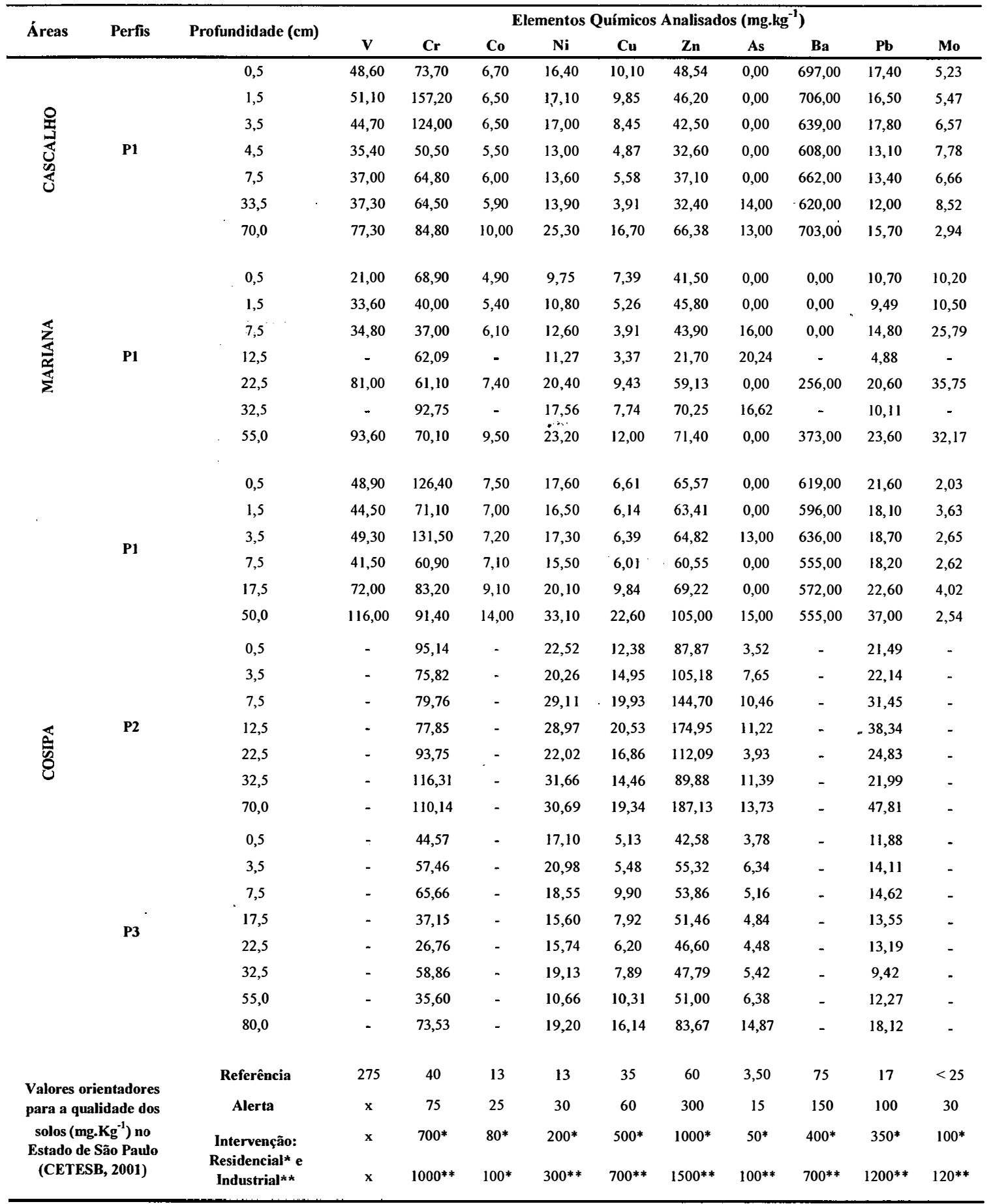


Tabela 4.5. Teores de V, Cr, Co, Ni, Cu, Zn, As, Ba, $\mathrm{Pb}$ e Mo (mg.kg $\left.{ }^{-1}\right)$ da área dos manguezais da Ilha do Cardoso e Valores Orientadores para a qualidade dos solos no Estado de São Paulo (CETESB, 2001a)

\begin{tabular}{|c|c|c|c|c|c|c|c|c|c|c|c|c|}
\hline \multirow{2}{*}{ Áreas } & \multirow{2}{*}{ Perfis } & \multirow{2}{*}{$\begin{array}{l}\text { Profundidade } \\
\text { (cm) }\end{array}$} & \multicolumn{10}{|c|}{ Elementos Químicos Analisados (mg.kg ${ }^{-1}$ ) } \\
\hline & & & $\mathbf{v}$ & $\mathbf{C r}$ & Co & $\mathrm{Ni}$ & $\mathrm{Cu}$ & $\mathbf{Z n}$ & As & $\mathbf{B a}$ & $\mathbf{P b}$ & Mo \\
\hline \multirow{19}{*}{ 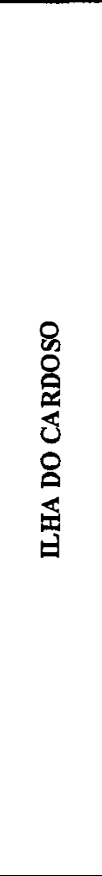 } & \multirow{4}{*}{$\mathbf{P 1}$} & 2,5 & 75,30 & 67,40 & 7,10 & 16,90 & 11,30 & 51,13 & 0,00 & 806,40 & 23,70 & 8,76 \\
\hline & & 7,5 & 58,40 & 58,70 & 6,60 & 13,20 & 5,69 & 48,02 & 0,00 & 852,40 & 19,50 & 13,10 \\
\hline & & 22,5 & 70,00 & 60,60 & 8,10 & 17,50 & 10,80 & 57,61 & 13,00 & 763,30 & 21,10 & 9,74 \\
\hline & & 70,0 & 71,20 & 70,40 & 8,00 & 17,20 & 10,80 & 58,89 & 14,00 & 768,60 & 18,30 & 9,43 \\
\hline & \multirow{5}{*}{ P2 } & 0,5 & 0,04 & 20,05 & - & - & - & 16,73 & 4,06 & - & 5,49 & - \\
\hline & & 3,5 & - & - & - & - & - & 20,31 & 1,76 & - & 8,10 & - \\
\hline & & 7,5 & - & - & - & - & - & 20,26 & 4,39 & - & 6,59 & - \\
\hline & & 22,5 & - & 25,80 & - & - & - & 14,37 & 3,31 & - & 5,51 & - \\
\hline & & 70,0 & - & - & - & - & - & 61,81 & 7,23 & - & 13,18 & - \\
\hline & \multirow{5}{*}{ P3 } & 0,5 & - & 71,08 & - & 12,91 & 11,69 & 40,41 & 11,44 & - & 11,20 & - \\
\hline & & 3,5 & - & 46,01 & - & 25,77 & 7,90 & 53,66 & 10,57 & - & 15,43 & - \\
\hline & & 7,5 & - & 64,87 & - & 14,44 & 5,58 & 53,23 & 10,89 & - & 17,20 & - \\
\hline & & 22,5 & - & 63,22 & - & 11,57 & 4,66 & 37,70 & 9,87 & - & 11,58 & - \\
\hline & & 60,0 & - & 74,68 & - & 20,61 & 7,64 & 55,48 & 8,81 & - & 18,43 & - \\
\hline & \multirow{5}{*}{ P4 } & 0,5 & 26,90 & 39,40 & 5,20 & 8,54 & 5,75 & 17,60 & 0,00 & 120,00 & 7,49 & 6,72 \\
\hline & & 1,5 & 27,10 & 34,80 & 5,30 & 7,81 & 1,77 & 16,80 & 0,00 & 93,10 & 9,69 & 7,43 \\
\hline & & 7,5 & 35,70 & 49,80 & 5,50 & 9,62 & 3,21 & 23,20 & 0,00 & 214,00 & 10,20 & 6,97 \\
\hline & & 22,5 & 26,00 & 35,20 & 5,20 & 8,35 & 1,69 & 16,40 & 0,00 & 79,10 & 5,92 & 8,26 \\
\hline & & 70,0 & 40,10 & 71,10 & 5,70 & 11,40 & 2,37 & 27,90 & 0,00 & 169,00 & 8,65 & 7,31 \\
\hline \multirow{4}{*}{\multicolumn{2}{|c|}{$\begin{array}{c}\text { Valores } \\
\text { orientadores para a } \\
\text { qualidade dos solos } \\
\left(\mathrm{mg.Kg}^{-1}\right) \text { no Estado } \\
\text { de São Paulo } \\
\text { (CETESB, 2001) }\end{array}$}} & Referência & 275,00 & 40 & 13 & 13 & 35 & 60 & 3,50 & 75 & 17 & $<25$ \\
\hline & & Alerta & $x$ & 75 & 25 & 30 & 60 & 300 & 15 & 150 & 100 & 30 \\
\hline & & $\begin{array}{l}\text { Intervenção: } \\
\text { Residencial* e }\end{array}$ & $\mathrm{x}$ & $700^{*}$ & $80^{*}$ & $200^{*}$ & $500^{*}$ & $1000 *$ & $50^{*}$ & $400^{*}$ & $350^{*}$ & $100^{*}$ \\
\hline & & Industrial $^{* * *}$ & $\mathrm{x}$ & $1000^{* *}$ & $100^{*}$ & $300^{* *}$ & $700^{* *}$ & $1500^{* *}$ & $100^{* *}$ & $700^{* *}$ & $1200^{* *}$ & $120^{* *}$ \\
\hline
\end{tabular}

\section{Crómio}

$\mathrm{O}$ crómio apresenta valores acima do estabelecido como referência (40 mg. $\left.\mathrm{kg}^{-1}\right)$ para os solos do manguezal do rio Crumahú e Irirí P28 e P16 (Tabela 4.3), Mariana e COSIPA P3 (Tabela 4.4) e Ilha do Cardoso P1, P3 e P4 (Tabela 4.5), indicando que estes solos não podem ser considerados com boa qualidade. Observa-se ainda que, para os solos do manguezal do Irirí P3 (73 a 98 mg.kg ${ }^{-1}$ ), do Cascalho (50 a 157 mg.kg ${ }^{-1}$ ), do canal da COSIPA P1 (60 a 126 mg.kg-1) e P2 (75 a 116 mg.kg $\left.{ }^{-1}\right)$ os valores apresentados ultrapassam os estabelecidos para alerta $\left(75 \mathrm{mg} \cdot \mathrm{kg}^{-1}\right)$, indicando certo grau de poluição. 


\section{Molibdênio}

Através das Tabelas 4.3, 4.4, e 4.5, verifica-se que somente o solo do perfil 15 do manguezal do rio Crumahú (30 a $42 \mathrm{mg} \cdot \mathrm{kg}^{-1}$ ) e do perfil analisado para o Mariana, em profundidade (32 e $36 \mathrm{mg} \cdot \mathrm{kg}^{-1}$ ), apresentam-se como poluídos por molibdênio, ou seja, acima do valor de alerta $\left(30 \mathrm{mg} \cdot \mathrm{kg}^{-1}\right)$.

\section{Níquel}

Os teores de níquel para os solos dos manguezais avaliados, encontram-se acima do valor de referência (13 mg. $\mathrm{kg}^{-1}$ ), em todos os perfis de solo do Crumahú, Irirí (Tabela 4.3), Cascalho, Mariana (Tabela 4.4), Ilha do Cardoso (Tabela 4.5) e canal da COSIPA (Tabela 4.4). Entretanto, para os solos do manguezal do canal da COSIPA, verifica-se no perfil 1 e 2 em profundidade, valores próximos ao estabelecido como alerta $\left(30 \mathrm{mg} \cdot \mathrm{kg}^{-1}\right)$.

\section{Vanádio}

Através das Tabelas 4.3, 4.4, e 4.5, verifica-se que os valores obtidos para o vanádio nos solos dos manguezais estudados apresentam-se abaixo do estabelecido como referência para solos de boa qualidade $\left(275 \mathrm{mg} \cdot \mathrm{kg}^{-1}\right)$.

\section{Zinco}

De modo geral, o zinco apresenta teores acima do valor estabelecido como referência para um solo de boa qualidade $\left(60 \mathrm{mg} . \mathrm{kg}^{-1}\right.$ ) (Tabelas 4.3, 4.4, e 4.5), em todos os perfis de solos dos manguezais analisados na Baixada Santista, com exceção aos da Ilha do Cardoso. Nos manguezais da Baixada Santista, o maior teor foi encontrado para o perfil 2 do canal da COSIPA a $70 \mathrm{~cm}$ de profundidade $\left(187 \mathrm{mg} \cdot \mathrm{kg}^{-1}\right)$.

\subsubsection{Marismas}

Neste segmento serão discutidos, fundamentalmente para fins de comparação, os resultados com base nos critérios da CETESB e da agência canadense, uma vez que até 
o momento não há uma definição na legislação atual da Galícia e nem da Espanha, para avaliar a qualidade dos solos em relação ao conteúdo de elementos traço no solo.

\section{Arsênio}

Nos solos das marismas de Pontevedra e Caldebarcos, o arsênio apresenta teores acima do estabelecido como alerta (15 mg.kg $\left.{ }^{-1}\right)$ segundo CETESB (2001), principalmente em superfície (Tabela 4.6), indicando certo grau de poluição e ainda, teores acima do valor estabelecido para intervenção no solo do perfil 2 da marisma de Pontevedra (328 mg. $\mathrm{kg}^{-1}$ ), indicando que o solo apresenta contaminação por este elemento. Quando comparados com o TEL e PEL, os solos em questão apresentam concentrações de arsênio que podem estar causando efeitos adversos à comunidade biológica do local.

\section{Chumbo}

Assim como para o elemento arsênio, o chumbo apresenta teores acima do estabelecido como referência $\left(17 \mathrm{mg} \cdot \mathrm{kg}^{-1}\right)$ para os solos das marismas de Pontevedra e Caldebarcos (Tabela 4.6), indicando que a qualidade destes solos está alterada. Observase ainda, no solo do perfil 2 da marisma de Pontevedra que o teor de chumbo encontrase acima do estabelecido para intervenção $\left(815 \mathrm{mg} \cdot \mathrm{kg}^{-1}\right)$, indicando que o solo apresenta contaminação por este elemento. Quando comparados com o TEL e PEL, verifica-se que apenas os solos da marisma de Pontevedra apresentam teores de chumbo que podem implicar em efeitos adversos à comunidade biológica do local.

\section{Cobre}

Os teores de cobre quando comparados com os valores orientadores estabelecidos pela CETESB (2001) e com o TEL e PEL (ENVIRONMENT CANADA, 1999), encontram-se acima dos valores estabelecidos como alerta $\left(60 \mathrm{mg}^{\mathrm{kg}} \mathrm{kg}^{-1}\right)$ causando poluição ou de alguma forma, efeitos adversos à comunidade biológica apenas para os solos da marisma de Pontevedra (Tabela 4.6). Ainda que de forma descontínua nos 
perfis do solo desta marisma, o elemento em questão apresentou valores que variaram de 7 a $356 \mathrm{mg} \cdot \mathrm{kg}^{-1}$.

\section{Crómio}

O crómio (Tabela 4.6) para os solos das marismas de Pontevedra e Caldebarcos apresenta, de forma descontinua, teores acima do estabelecido como referência e alerta (40 e 75mg. $\mathrm{kg}^{-1}$ respectivamente) segundo CETESB (2001), indicando que sua qualidade encontra-se alterada e ainda certo grau de poluição, no solo do perfil 1 da marisma de Caldebarcos (425mg. $\mathrm{kg}^{-1}$ ). Quando comparados com o TEL e PEL, os solos em questão apresentam concentrações deste elemento que podem estar causando efeitos adversos à comunidade biológica do local. 
Tabela 4.6. Teores de $\mathrm{Cr}, \mathrm{Pb}, \mathrm{Ni}, \mathrm{Cu}, \mathrm{Zn}$ e $\mathrm{As}\left(\mathrm{mg}^{\mathrm{kg}}{ }^{-1}\right)$ das áreas das áreas das marismas de Pontevedra e Caldebarcos, e Valores Orientadores para a qualidade dos solos no Estado de São Paulo (CETESB, 2001a)

\begin{tabular}{|c|c|c|c|c|c|c|c|c|}
\hline \multirow{2}{*}{ Áreas } & \multirow{2}{*}{ Perfis } & \multirow{2}{*}{$\begin{array}{l}\text { Profundidade } \\
\text { (cm) }\end{array}$} & \multicolumn{6}{|c|}{ Elementos Químicos Analisados (mg.kg ${ }^{-1}$ ) } \\
\hline & & & $\mathbf{P b}$ & $\mathbf{C r}$ & $\mathbf{N i}$ & $\mathbf{C u}$ & Zn & As \\
\hline \multirow{16}{*}{ 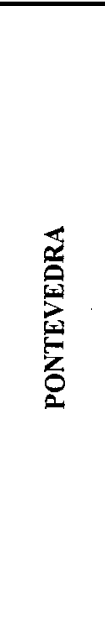 } & \multirow{7}{*}{ P1 } & 2,5 & 80,36 & 28,21 & 23,33 & 68,76 & 569,34 & 28,88 \\
\hline & & 7,5 & 83,95 & 40,44 & 23,57 & 64,05 & 576,90 & 30,77 \\
\hline & & 12,5 & 80,80 & 40,38 & 26,70 & 71,31 & 552,46 & 31,13 \\
\hline & & 22,5 & 55,43 & 46,75 & $.17,19$ & 37,22 & 317,80 & 24,59 \\
\hline & & 37,5 & 56,38 & 30,56 & 13,12 & 33,06 & 214,82 & 12,62 \\
\hline & & 52,5 & 41,49 & 27,71 & 8,91 & 25,08 & 207,19 & 9,01 \\
\hline & & 57,5 & 30,35 & 25,07 & 6,00 & 9,74 & 98,30 & 2,93 \\
\hline & \multirow{9}{*}{ P2 } & 2,5 & 74,34 & 74,65 & 37,59 & 72,57 & 431,21 & 43,45 \\
\hline & & 7,5 & 58,70 & 41,04 & 28,72 & 55,44 & 337,06 & 36,65 \\
\hline & & 12,5 & 56,20 & 39,88 & 24,19 & 50,10 & 306,48 & 48,84 \\
\hline & & 22,5 & 815,38 & 46,10 & 19,60 & 356,57 & 1212,93 & 328,11 \\
\hline & & 32,5 & 325,57 & 62,77 & 15,46 & 112,78 & 613,94 & 70,66 \\
\hline & & 52,5 & 86,10 & 26,20 & 6,15 & 32,28 & 166,52 & 32,06 \\
\hline & & 57,5 & 38,28 & 21,01 & 6,90 & 7,92 & 84,77 & 8,50 \\
\hline & & 87,5 & 28,84 & 29,27 & 22,08 & 14,59 & 91,95 & 16,16 \\
\hline & & 97,5 & 25,21 & 25,23 & 20,98 & 7,25 & 78,24 & 12,47 \\
\hline \multirow{18}{*}{ 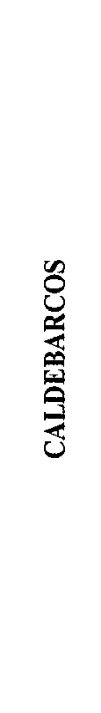 } & \multirow{9}{*}{ P1 } & 2,5 & 24,79 & 42,40 & 15,10 & 7,34 & 80,55 & 38,76 \\
\hline & & 7,5 & 34,00 & 73,24 & 21,70 & 9,88 & 75,59 & 35,88 \\
\hline & & 12,5 & 28,92 & . - & 18,94 & 9,74 & 62,76 & 33,76 \\
\hline & & 22,5 & 23,75 & 62,87 & 10,70 & 5,05 & 49,00 & 17,67 \\
\hline & & 37,5 & 18,26 & 30,33 & 6,45 & - & 28,19 & 4,78 \\
\hline & & 52,5 & 18,77 & - & 10,76 & - & 25,83 & 4,66 \\
\hline & & 57,5 & 19,83 & 28,06 & 10,75 & 2,58 & 32,64 & 4,20 \\
\hline & & 85,0 & 16,39 & 425,17 & - & - & 22,73 & 2,86 \\
\hline & & 95,0 & 12,23 & 12,63 & - & - & 55,65 & 5,47 \\
\hline & \multirow{9}{*}{ P2 } & 1,0 & 24,76 & 49,24 & 29,58 & 10,98 & 83,67 & 33,98 \\
\hline & & 3,0 & 30,99 & 66,36 & 25,71 & 10,65 & 82,61 & 41,23 \\
\hline & & 7,5 & 34,04 & 71,24 & 20,06 & 7,76 & 84,76 & 38,29 \\
\hline & & 12,5 & 24,11 & 59,22 & - & 4,27 & 55,86 & 19,91 \\
\hline & & 22,5 & 24,69 & 34,25 & 10,87 & 3,97 & 49,09 & 12,20 \\
\hline & & 40,0 & 21,69 & - & 6,36 & - & 37,03 & 2,20 \\
\hline & & 60,0 & 20,04 & 20,03 & 7,07 & 3,36 & 32,43 & 5,30 \\
\hline & & 125,0 & 14,55 & 32,63 & 9,91 & 2,46 & 21,37 & - \\
\hline & & 135,0 & 10,94 & 43,78 & 12,73 & 3,15 & 13,06 & . \\
\hline \multirow{4}{*}{\multicolumn{2}{|c|}{ 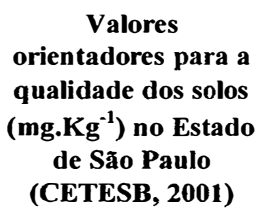 }} & Referência & 17,000 & 40 & 13 & 35 & 60 & 3,50 \\
\hline & & Alerta & 100,000 & 75 & 30 & 60 & 300 & 15 \\
\hline & & Intervençāo: & $350 *$ & $700^{*}$ & $200^{*}$ & $500 *$ & $1000 *$ & $50^{*}$ \\
\hline & & Industrial** & $1200 * *$ & $1000^{* *}$ & $300^{* *}$ & $700 * *$ & $1500^{* *}$ & $100^{* *}$ \\
\hline \multirow{2}{*}{\multicolumn{2}{|c|}{$\begin{array}{l}\text { ENVIRONMENT } \\
\text { CANADA, } 1999\end{array}$}} & TEL & 30,2 & 52,3 & 15,9 & 18,7 & 124 & 7,24 \\
\hline & & PEL & 112 & 160 & 42,8 & 108 & 271 & 41,6 \\
\hline
\end{tabular}

TEL (Threshold effect level): Nível limiar abaixo do qual não ocorre efeito adverso à comunidade biológica.

PEL (Probable Effect Level): Nível provável de efeito adverso à comunidade biológica (frequientemente associado a efeitos biológicos).

$\mathbf{x}=$ não existe critério para este parâmetro 


\section{Níquel}

O níquel para os solos das marismas de Pontevedra e Caldebarcos (Tabela 4.6) apresenta teores acima do estabelecido como referência $\left(13 \mathrm{mg} \cdot \mathrm{kg}^{-1}\right)$ e do TEL $(15,9$ $\mathrm{mg} \cdot \mathrm{kg}^{-1}$ ) indicando que a qualidade destes solos pode estar alterada ou ainda que o elemento em questão, pode estar causando efeitos adversos à comunidade biológica do local.

\section{Zinco}

O zinco apresenta-se em concentrações acima dos valores estabelecido como referência (60 mg. $\mathrm{kg}^{-1}$ ) para os perfis de solo da marisma de Caldebarcos e acima dos valores de alerta $\left(300 \mathrm{mg} \cdot \mathrm{kg}^{-1}\right)$ para a marisma de Pontevedra, principalmente nas camadas superficial e subsuperficial com teores variando entre 78 e $1213 \mathrm{mg} \cdot \mathrm{kg}^{-1}$ (Tabela 4.6a). Com base nos resultados obtidos para este elemento, verifica-se que os solos da marisma de Caldebarcos apresentam sua qualidade alterada, mas em relação ao TEL e PEL, o zinco não está causando efeitos adversos à comunidade biológica. Em contrapartida, verifica-se que os solos da marisma de Pontevedra estão poluídos por este elemento que pode estar causando efeitos adversos à comunidade biológica do local.

\subsection{Comportamento geoquímico de elementos traço em solos de manguezais e de marisma}

\subsubsection{Comportamento geoquímico do Fe}

O ferro pirítico foi a fração dominante na maior parte dos solos de manguezais, seguido do Fe-lepidocrocítico (F4), Fe-cristalino (F5), Fe-ferrihidrítico e, em menor medida, o Fe-carbonato (F2) e o Fe-trocável (F1) (Tabela 4.5, Figura 4.15). Somente na parte mais superficial de alguns dos solos (p. ex. o ponto T1P1 do rio Crumahú, e no ponto P1 do rio Cascalho) os oxihidróxidos de Fe apresentaram uma concentração superior à fração. Abaixo dos $4 \mathrm{~cm}$ de profundidade as formas cristalinas experimentam uma forte redução, passando a dominar o Fe-pirítico. Em geral, estas altas concentrações de Fe-pirítico estão de acordo com as condições redox, apresentando estas duas variáveis uma correlação altamente significativa $\left(r_{s}=-0,551, p<0,001, n=47\right)$. Os potenciais redox 
obtidos oscilaram entre 144 e $-174 \mathrm{mV}$, o que significa dizer que foram encontradas condições subóxicas (Eh: 100-300 mV) na parte mais superficial de alguns dos solos. Em subsuperfície, e até mesmo em amostras relativamente superficiais, dominam as condições anóxicas.

Tabela 4.5. Concentração do Fe $\left(\mu \mathrm{mol} . \mathrm{g}^{-1}\right)$ obtido para as diferentes frações nos solos de manguezais

\begin{tabular}{llll}
\hline & Máximo & Mínimo & média \pm sd \\
\hline F1 & 6,33 & $<$ LD & $0,23 \pm 0,65$ \\
F2 & 3,76 & $<$ LD & $0,65 \pm 0,87$ \\
F3 & 49,60 & 0,64 & $13,6 \pm 10,5$ \\
F4 & 91,50 & 6,92 & $24,72 \pm 15,9$ \\
F5 & 106,1 & 1,21 & $16,11 \pm 7,47$ \\
F6 & 733,4 & 2,71 & $108,8 \pm 52,1$ \\
\hline
\end{tabular}

A presença de oxihidróxidos de $\mathrm{Fe}$ em solos anóxicos foi constatada em trabalhos anteriores (Otero \& Macías, 2002 a, b). Neste sentido é necessário ter em mente que os valores de Eh expressam as condições dominantes no sistema, mas não aquelas que podem acontecer em determinados microsistemas como, a rizosfera e os canais realizados pela fauna do solo. Nestes micro ambientes pode produzir-se a oxidação da pirita, assim como de outros sulfetos de Fe menos estáveis (p. ex. FeS). Esta idéia baseia-se no fato de ter-se encontrado concentrações elevadas de oxihidróxidos de Fe, tanto em superfície como em profundidade. Sua presença pode ser entendida como conseqüência da 'oxidação da pirita, o que dá como resultado, num primeiro momento, $\mathrm{FeSO}_{4} \mathrm{H}_{2} \mathrm{O}$, o qual evolui para lepidocrocita $(\gamma-\mathrm{FeOOH})$ e acaba envelhecendo finalmente como goethita $(\alpha-\mathrm{FeOOH})$ (Luther et al., 1991). Por outra parte, também alguns autores indicam a presença de formas pouco cristalinas de oxihidróxidos de $\mathrm{Fe}$ (ferridrita) em torno dos cristais de pirita quando esta se encontra submetida a meios oxidantes e que, por sua vez, contribui a reduzir a velocidade de sua oxidação (Ritsema \& Groenenberg, 1993; Zhang \& Evangeleu, 1996). 
Os solos das marismas apresentam uma variação em suas condições redox muito mais ampla do que os solos de manguezais, encontrando-se desde solos com condições redox óxicas, principalmente na superfície com valores de $\mathrm{Eh}>300 \mathrm{mV}$, solos subóxicos em profundidade (Eh: 100-300 mV) e solos fortemente reduzidos com valores de $\mathrm{Eh}<$ $100 \mathrm{mV}$ já desde a superfície. A distribuição de uns e outros são condicionados por dois parâmetros básicos: tipo e fisiografia da marisma. Existem então dois tipos de marismas nas rías galegas: marisma alta e marisma baixa (Otero \& Macías, 2001).

A marisma alta, está dominada pela junqueira (associação de Limonio serotini e Juncetum maritimi), e sua altura média se situa acima do nível médio das preamares, a qual somente fica totalmente inundada em momentos de preamares vivas ou preamares de maior amplitude. Por tanto, é onde estão presentes os solos com condições mais oxidantes (predominantemente óxicas ou subóxicas). No entanto, esta situação pode mudar dependendo de pequenas variações na microtopografia, sendo comum encontrar solos fortemente reduzidos que correspondem a pequenas depressões, mal drenadas e permanentemente encharcadas. Quando isto ocorre a junqueira desaparece e se instala Spartina maritima. A situação contrária corresponde às margens de canais onde aparece a dicotiledônea Halimione portulacoides, que apresenta condições oxidantes praticamente até alcançar o fundo do canal.

As condições mais fortemente reduzidas, com $\mathrm{Eh}<100 \mathrm{mV}$ já em superfície, aparecem na marisma baixa. Esta parte da marisma fica inundada por todo tipo de preamares e, além do tempo de inundação em cada ciclo mareal, não é muito mais elevada que na marisma alta, já que é a primeira a ficar inundada ao subir a maré e a última a ficar descoberta ao descender o nível da maré (para mais detalhe ver Otero \& Macías, 2001 e 2002). 

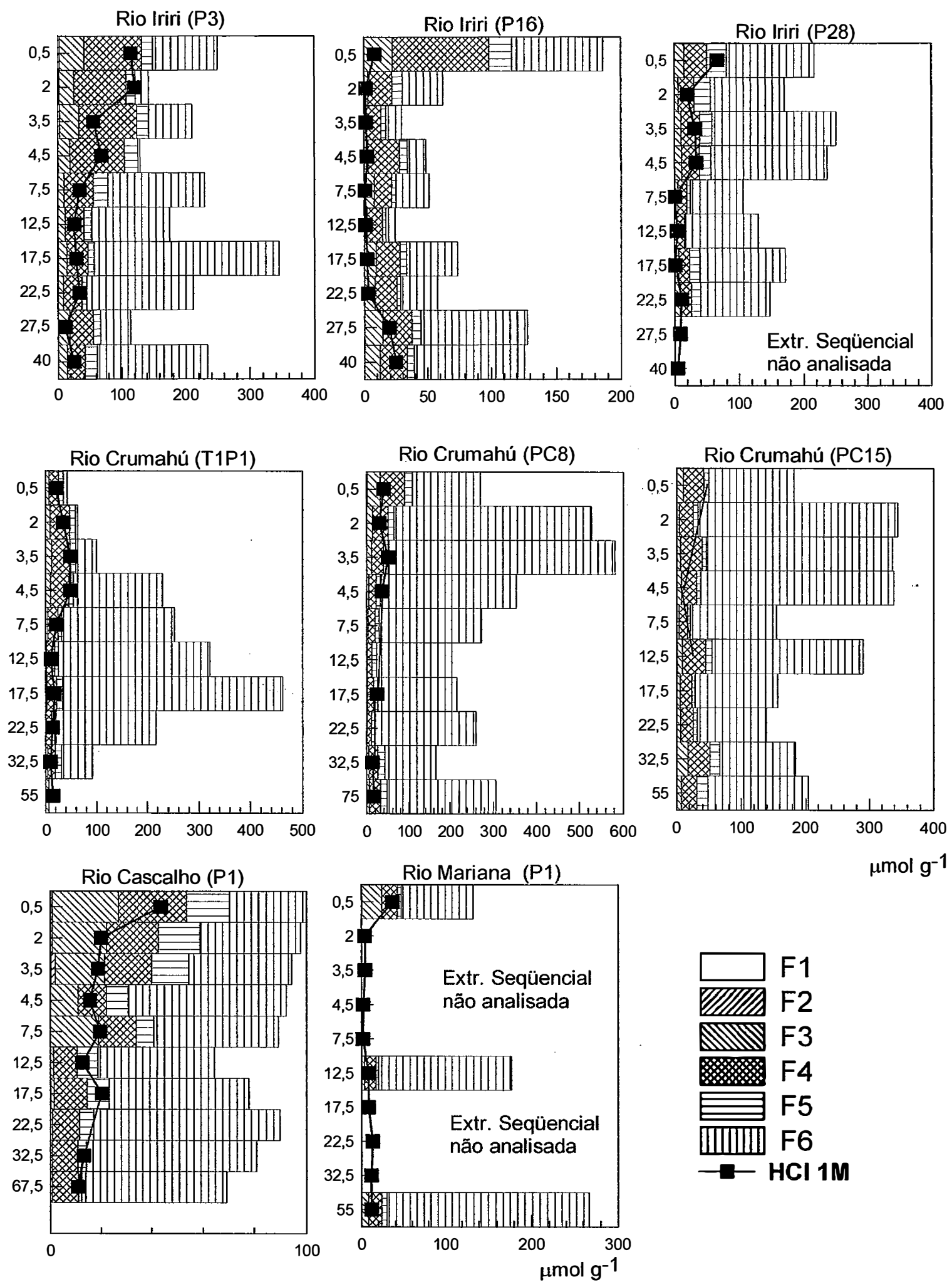

Figura 4.15a - Distribuição do Fe nas diferentes frações geoquímicas consideradas 

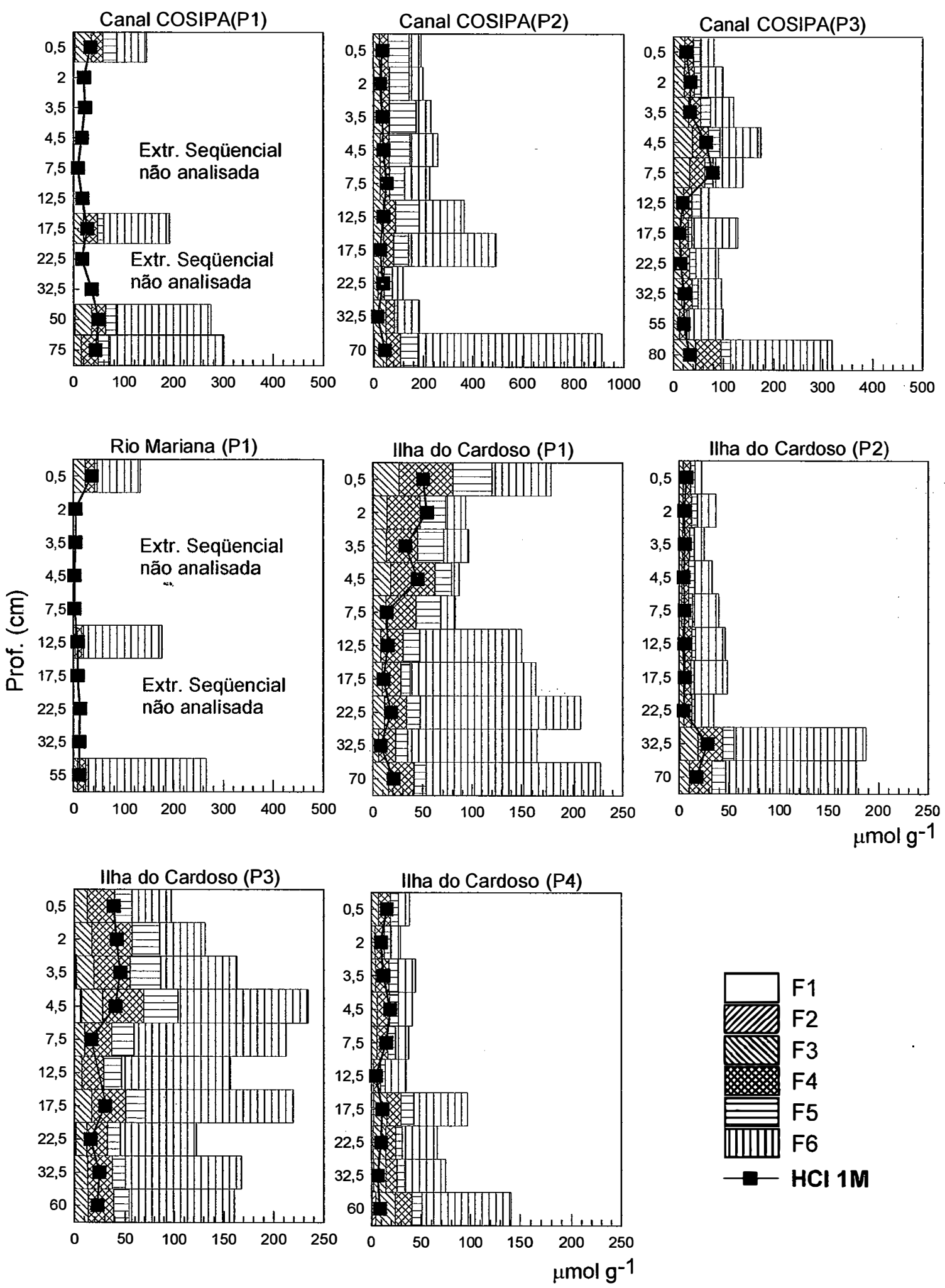

Figura 4.15b - Distribuição do Fe nas diferentes frações geoquímicas consideradas 
Em consonância com esta ampla variabilidade nas condições redox, os resultados encontrados para o fracionamento do $\mathrm{Fe}$ mostram grandes variações espaciais (Tabela 4.6, Figura 4.16). Na marisma alta, os oxihidróxidos de Fe são formas dominantes, normalmente na parte mais superficial do solo, mas especificamente na margem do canal, a dominância da forma oxihidróxido se estende a mais de $1 \mathrm{~m}$ de profundidade. É nas proximidades do fundo do canal onde se produz um aumento notável de Fe pirítico (Figura 4.17).

Tabela 4.6. Concentração do Fe $\left(\mu \mathrm{mol} . \mathrm{g}^{-1}\right)$ obtido para as diferentes frações nos solos de marisma

\begin{tabular}{llll}
\hline & Máximo & Mínimo & Média \pm sd \\
\hline F1 & 0,87 & $<$ LD & $0,09 \pm 0,19$ \\
F2 & 3,45 & 0,02 & $0,62 \pm 0,95$ \\
F3 & 112,8 & 2,42 & $33,1 \pm 25,3$ \\
F4 & 3,21 & $39,61 \pm 36,9$ \\
F5 & 186,4 & 3,71 & $41,28 \pm 71 ; 3$ \\
F6 & 370,8 & 0,17 & $169,2 \pm 110$ \\
\hline
\end{tabular}

Embora, em termos gerais a piritização nos solos da marisma é menos intensa do que no manguezal, deve-se destacar que em zonas mais anóxicas (marisma baixa) a piritização alcança valores similares aos encontrados no manguezal, muito provavelmente devido a ação oxidante das plantas de porte herbáceo presentes na marisma baixa (Spartina e principalmente Zostera) ser muito inferior às espécies arbóreas próprias do ecossistema de manguezais (Rhizophora, Avicennia, Laguncularia). 

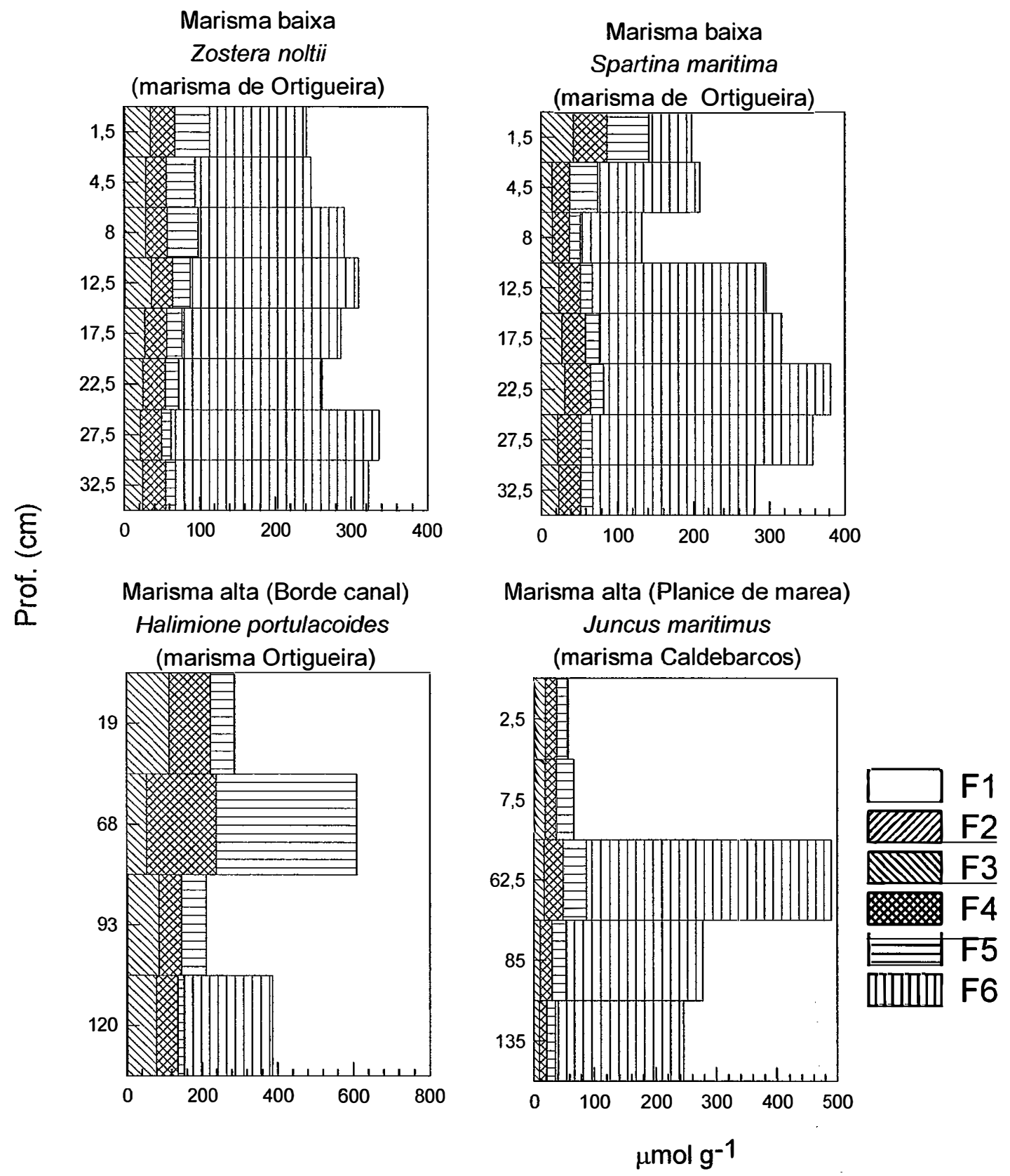

Figura 4.16 - Distribuição do $\mathrm{Fe}$ nos solos de marisma nas diferentes frações geoquímicas consideradas 

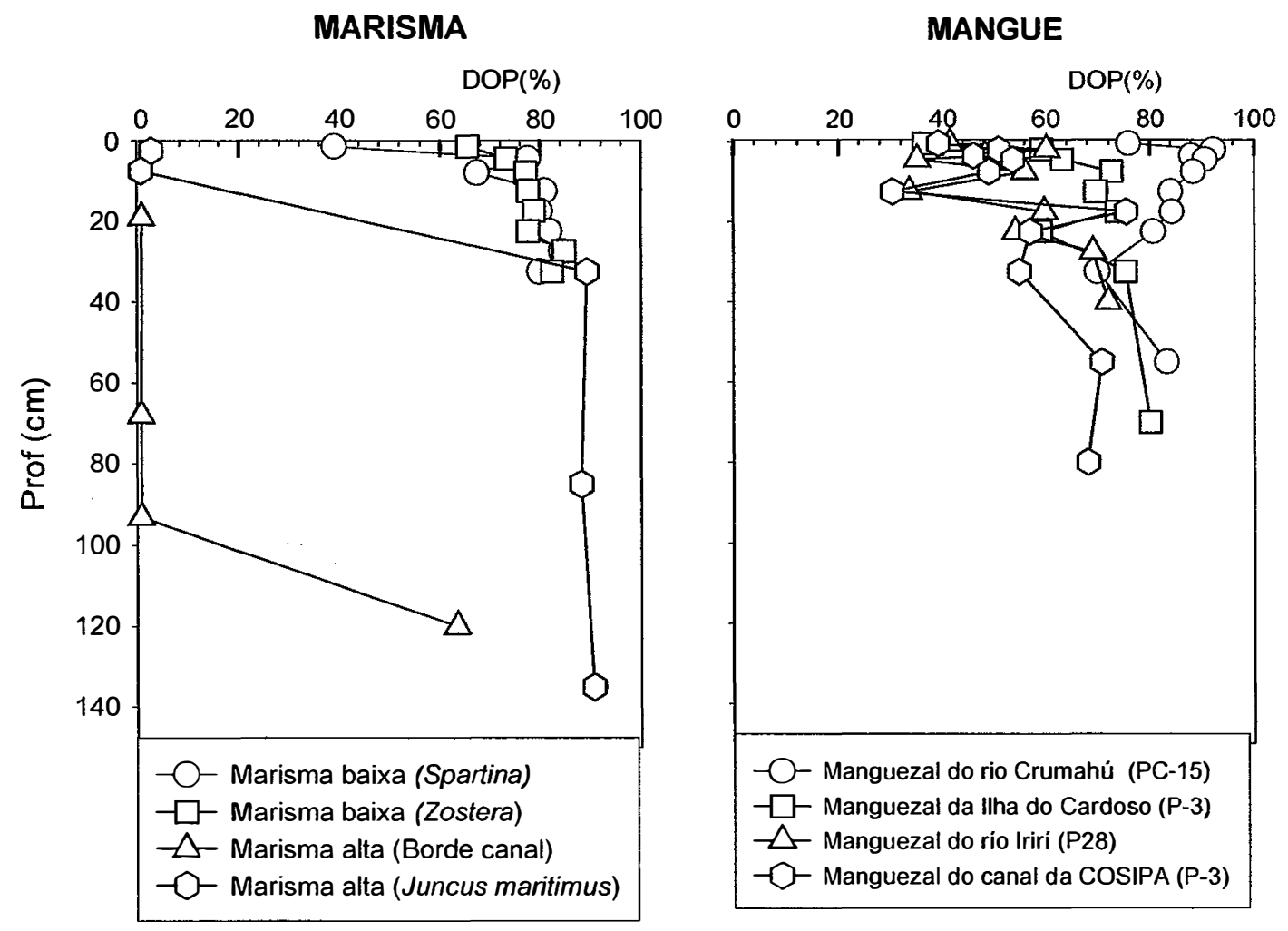

Figura 4.17 - Grau de piritização do Fe (DOP) em solos de marisma e manguezal

\subsubsection{Comportamento Geoquímico do Mn.}

Nas Tabelas 4.7 e 4.8 são apresentadas às concentrações de Mn obtidas para cada fração em solos de marismas e de manguezais. Estas Tabelas, assim como a Figura 4.18, demonstra que em muitos dos pontos do manguezal a fração F1 foi a dominante, representando para alguns dos solos mais do que 50\% do total do Mn extraído nas 6 frações consideradas. A segunda fração, em importância, é a pirítica seguida da fração carbonato e as frações que extraem as formas de Mn facilmente reduzíveis ou as associadas a formas pouco cristalinas de $\mathrm{Fe}$ (frações F3 e F4) e finalmente o Mn associado aos oxihidróxidos de Fe cristalino. 
Tabela 4.7. Concentração do $\mathrm{Mn}\left(\eta \operatorname{mol} . \mathrm{g}^{-1}\right)$ obtido para as diferentes frações nos solos de manguezais

\begin{tabular}{llll}
\hline & Máximo & Mínimo & Média \pm sd \\
\hline F1 & 7844 & 4,41 & $1110 \pm 766$ \\
F2 & 853,6 & 5,88 & $209,9 \pm 206$ \\
F3 & 898,9 & 82,48 & $191,5 \pm 150$ \\
F4 & 82,50 & $291,6 \pm 150$ \\
F5 & 698,9 & 2,77 & $73,90 \pm 74,5$ \\
F6 & 537,8 & 14,70 & $586,2 \pm 669$ \\
\hline
\end{tabular}

O comportamento geoquímico do Mn é complexo devido a vários fatores: 1) o Mn pode apresentar diversos estados de oxidação; 2) os óxidos de Mn podem existir em várias formas cristalinas e pseudocristalinas; 3) a redução microbiana dos óxidos de $\mathrm{Mn}$ depende do grau de cristalinidade do mineral; 4) o Mn pode co-precipitar com os oxihidróxidos de Fe (Burdige et al. 1992, Adriano, 2001).

Em condições anóxicas o $\mathrm{Mn}$ pode estar na forma iônica $\left(\mathrm{Mn}^{2+}\right)$ ou então precipitado ora como sulfeto (alabandita, $\mathrm{MnS}$, ou mais provavelmente como um precipitado misto associado com a pirita), ora como carbonato de manganês (rodocrocita, $\mathrm{MnCO}_{3}$ ). Determinar qual forma das anteriormente citadas controla $\mathrm{Mn}$ na solução não é fácil de estabelecer, já que os sulfetos e os carbonatos de Mn apresentam campos de estabilidade reduzidos e muito próximos (Figura 4.20). Devido a isto, em diversos trabalhos realizados em meios anóxicos tem-se reiterado que o Mn pode apresentar-se superiormente tanto na forma trocável como associado à fração pirítica ou ainda associado aos carbonatos (ver p. ex. Huerta-Díaz \& Morse, 1992; Kiratli \& Ergin, 1996; Morse \& Luther, 1999; Otero \& Macías, 2002, Otero et al. 2003). 

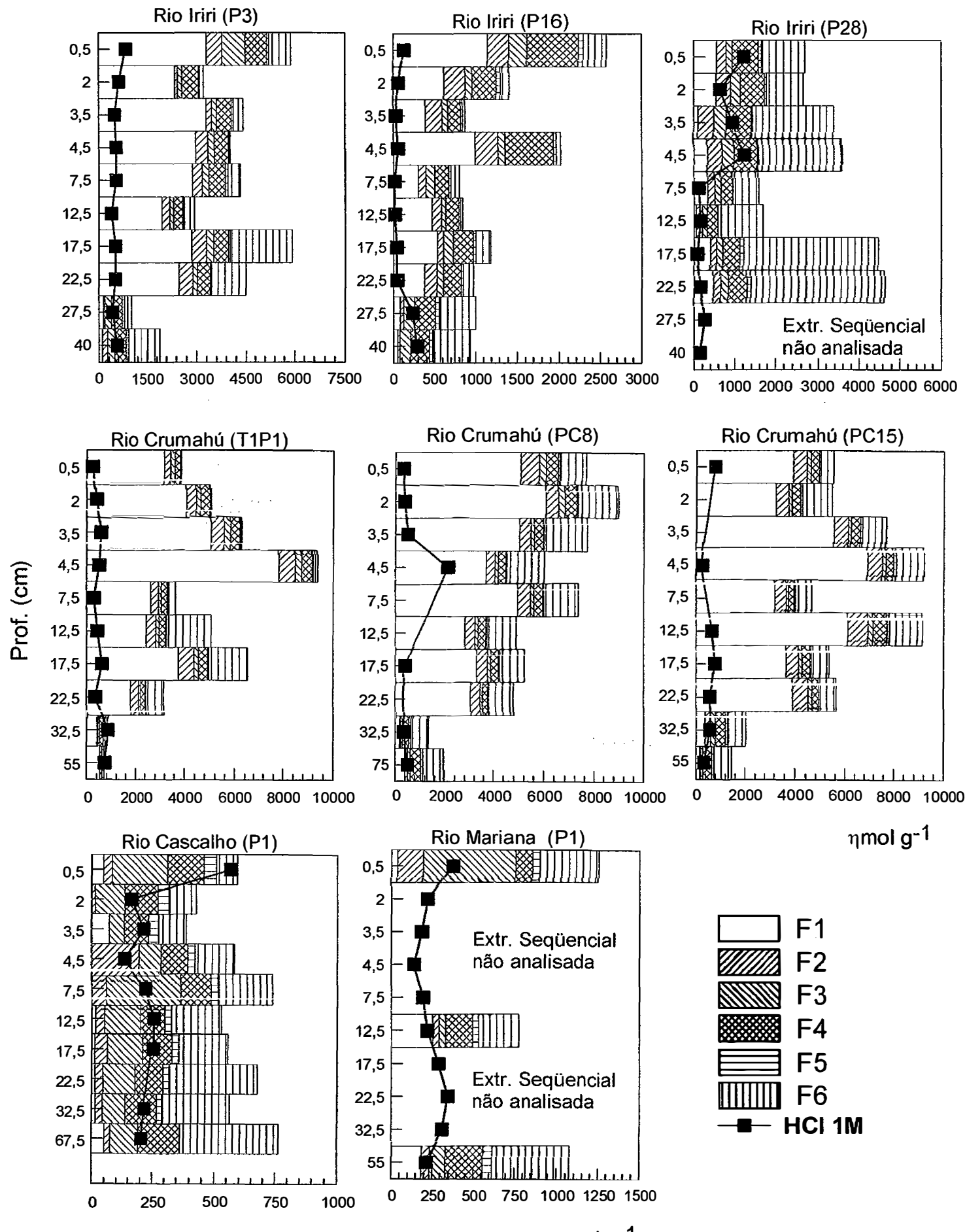

$\eta \mathrm{mol} \mathrm{g}-1$

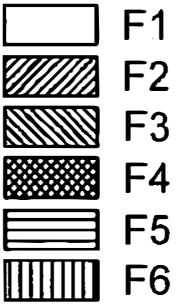

$\rightarrow-\mathrm{HCl} 1 \mathrm{M}$

$$
\eta \mathrm{mol} \mathrm{g}^{-1}
$$

Figura 4.18a - Distribuição do Mn nas diferentes frações geoquímicas consideradas 

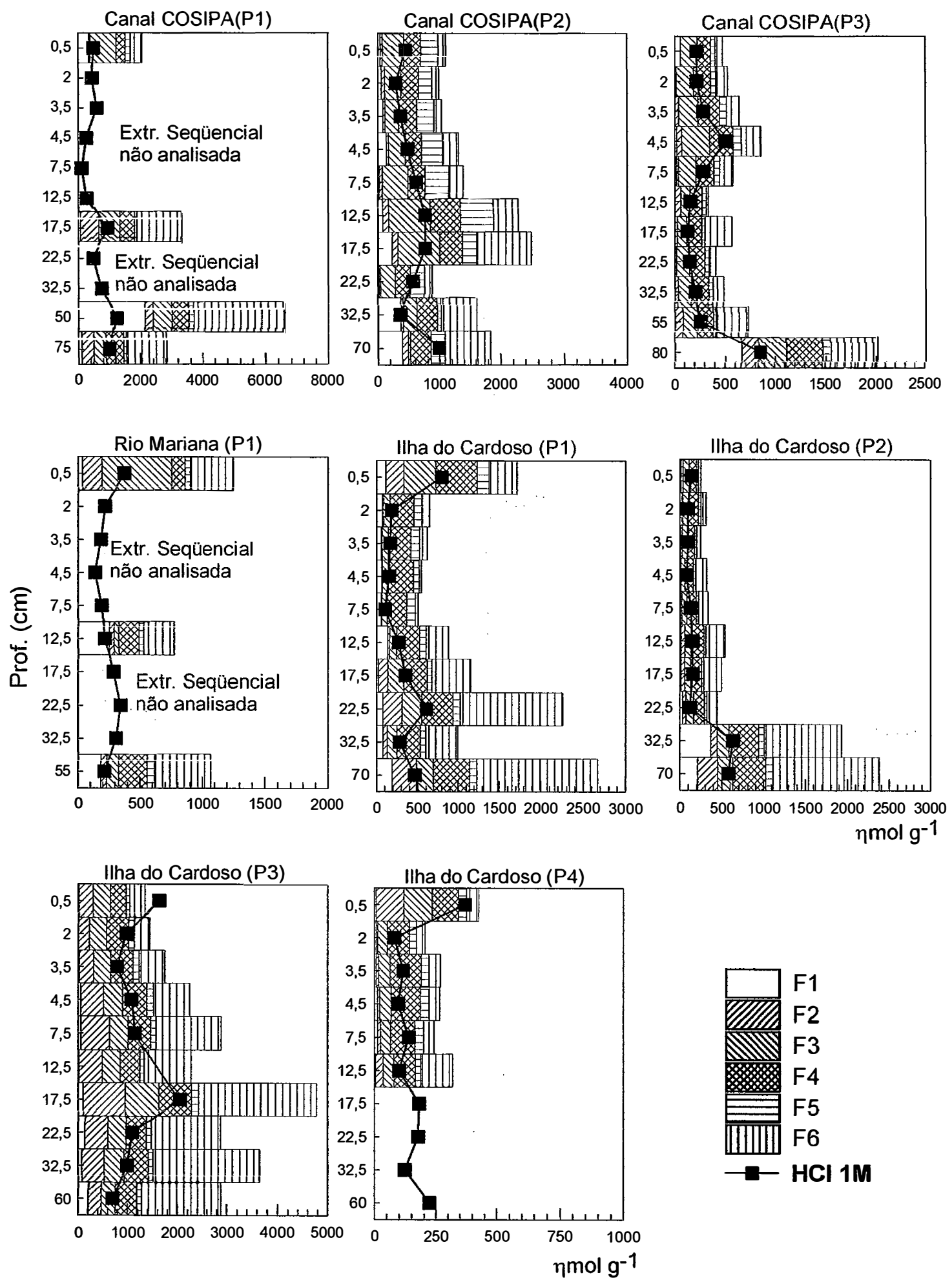

Figura 4.18b - Distribuição do Mn nas diferentes frações geoquímicas consideradas 
Nas condições de Eh-pH registradas neste estudo, o $\mathrm{Mn}^{2+}$ é a forma que se vê mais favorecida, o que explicaria sua dominância em boa parte dos solos. Elevadas concentrações na fração solúvel em água, assim como na fração trocável, foram encontradas também por outros autores em meios similares (Tam \& Wong, 1996; Ngiam $\&$ Lim, 2001). Por outro lado, as condições de pH dos solos de manguezais, com valores em geral compreendidos entre 6-7, indicam que a síntese da pirita é favorecida em detrimento da rodocrocita, já que para que esta última precipite é necessário um meio com $\mathrm{pH}$ superior a 8 (Figura 4.20).

Tabela 4.8. Concentração do $\mathrm{Mn}\left(\eta \mathrm{mol} \cdot \mathrm{g}^{-1}\right)$ obtido para as diferentes frações nos solos de marisma

\begin{tabular}{llll}
\hline & Máximo & Mínimo & média \pm sd \\
\hline F1 & 51,31 & $<$ LD & $19,14 \pm 10,1$ \\
F2 & 133,5 & $<$ LD & $50,84 \pm 31,5$ \\
F3 & 1657 & 74,16 & $399,3 \pm 329$ \\
F4 & 773,1 & 138,6 & $467,8 \pm 219$ \\
F5 & 441,1 & 42,91 & $105,1 \pm 71,5$ \\
F6 & 331,7 & $<$ LD & $331,7 \pm 256$ \\
\hline
\end{tabular}

Os resultados óbtidos para os solos das marismas mostraram diferenças importantes em relação aos solos de manguezais. Em primeiro lugar cabe destacar que, em concordância com as condições redox dos solos, existem dois padrões de distribuição do Mn. Por um lado se situam os solos da marisma baixa onde a incorporação do Mn à fração pirítica é importante, representando a primeira fração no solo sobre o qual se situa a espécie Zostera noltii. Por outro lado, apesar de tratar-se de solos anóxicos em superfície, preservam quantidades importantes de óxidos de $\mathrm{Fe} / \mathrm{Mn}$ de pouca cristalinidade, enquanto que o Mn trocável e o associado aos carbonatos representam uma parte muito reduzida do Mn extraído (Figura 4.19). Na marisma alta, onde as condições redox são óxicas na parte superficial do perfil e subóxica na parte profunda, o manganês está principalmente ou como óxidos de Mn ou associado às diferentes formas 
de oxihidróxidos $\mathrm{Fe}$ (frações F3, F4, F5) e só na parte mais profunda da margem do canal que, na verdade, já corresponde a um ambiente de fundo de canal, é que está fortemente reduzido $(\mathrm{Eh}=-120 \mathrm{mV}$ ) e onde se encontrou uma concentração importante de Mn associada à fração pirítica (Figura 4.19).

Outro aspecto importante que se pode observar nos solos da marisma alta (especialmente no solo da marisma de Caldebarcos) é o nítido enriquecimento em $\mathrm{Mn}$ que se encontrou na parte mais superficial do solo. Trata-se de um solo típico da planície mareal na que se assenta a Junqueira e que mostra condições óxicas em superfície $(E \mathrm{~h}=$ $384 \mathrm{mV}$ a 2,5 cm de profundidade) e subóxicas (Eh: 100-180 mV) (Figura 4.19). Considerando que a redução do manganês se inicia a partir de valores de Eh inferiores a $225 \mathrm{mV}$ (Patrick \& Jugsujunda, 1992), na parte mais profunda deste solo estaria se produzindo sua redução, passando à forma solúvel $\mathrm{Mn}^{2+}$ (Figuras 4.19 e 4.20).

$\mathrm{O}$ Mn solúvel pode difundir em direção da superfície. Este processo é favorecido pelo efeito que exercem as plantas sobre o solo. As plantas são capazes de gerar um forte gradiente de concentração na rizosfera que produz um fluxo de Fe e $\mathrm{Mn}$ em direção à superfície das raízes (Sundby et al., 1998). O Mn, ao contrário do Fe, apresenta uma cinética de oxidação com o oxigênio lenta, o que lhe permite permanecer como $\mathrm{Mn}^{2+}$ inclusive em meios oxidantes, precipitando na parte mais superficial do solo e até pode ser exportado pela água da maré (ver, por exemplo, Stumm \& Morgan, 1981, Caetano et al., 1997). Pelo contrário, no caso do Fe, este precipita antes mostrando o seu máximo teor, precipitando abaixo do Mn (Figura 4.18).

$\mathrm{O}$ menor enriquecimento de $\mathrm{Fe}$ em superfície pode estar relacionado com o fato de que este elemento precipita em profundidade como pirita $\left(\mathrm{FeS}_{2}\right)$, processo que apenas ocorre com o Mn, cujos sulfetos são muito mais solúveis (alabandita, $\mathrm{MnS}, \mathrm{pKps}=-1,3$; pirita, KPsp = -15,4) (Robie, 1966; Berner, 1970) e sua incorporação na fração pirítica, é sempre muito inferior à do $\mathrm{Fe}$ e ainda, porque costuma acontecer em situações onde as porcentagens de piritização do Fe são muito elevadas (Morse \& Luther, 1999; Otero \& Macías 2002). 

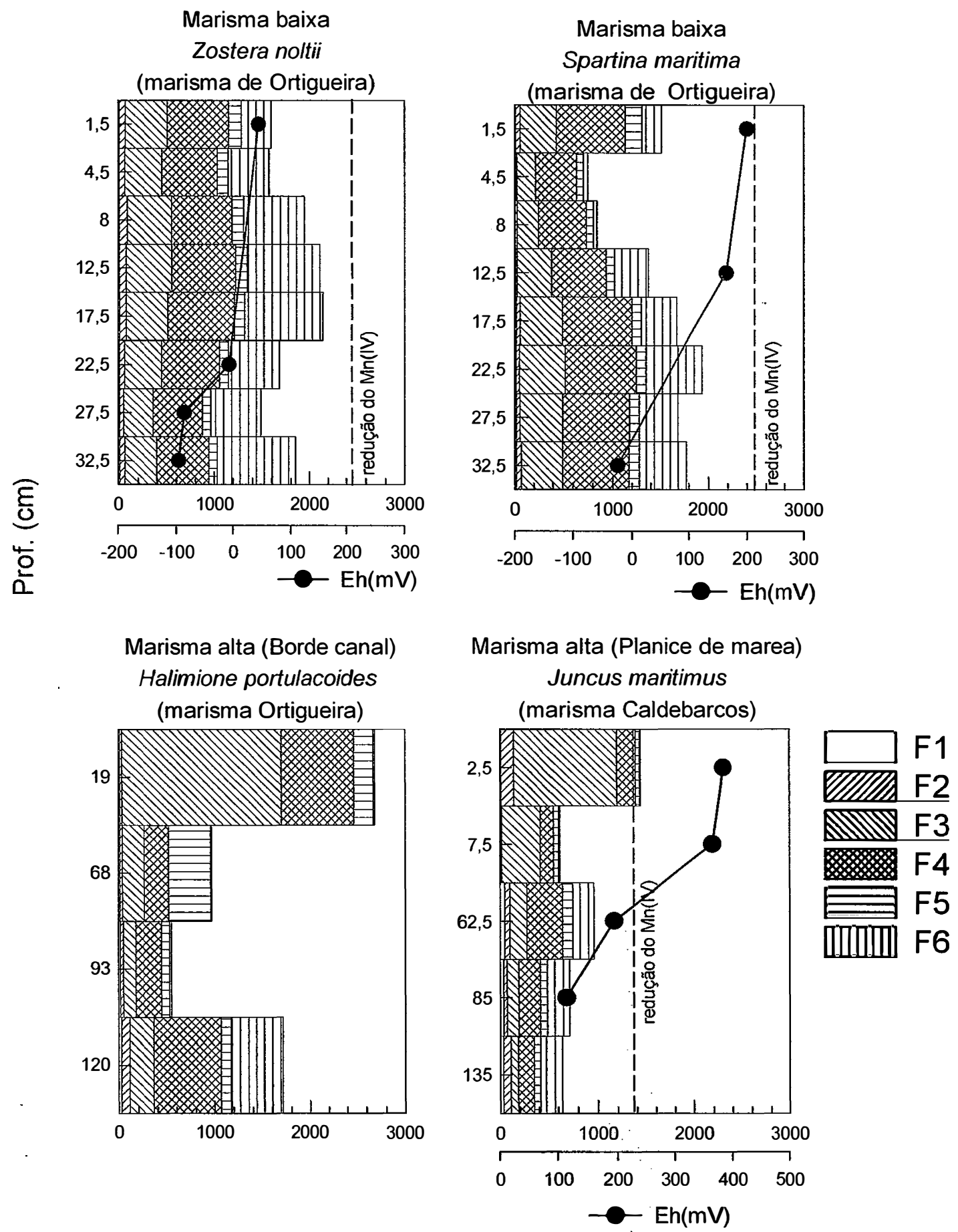

Figura 4.19 - Distribuição do Mn nos solos de marisma nas diferentes frações geoquímicas consideradas 


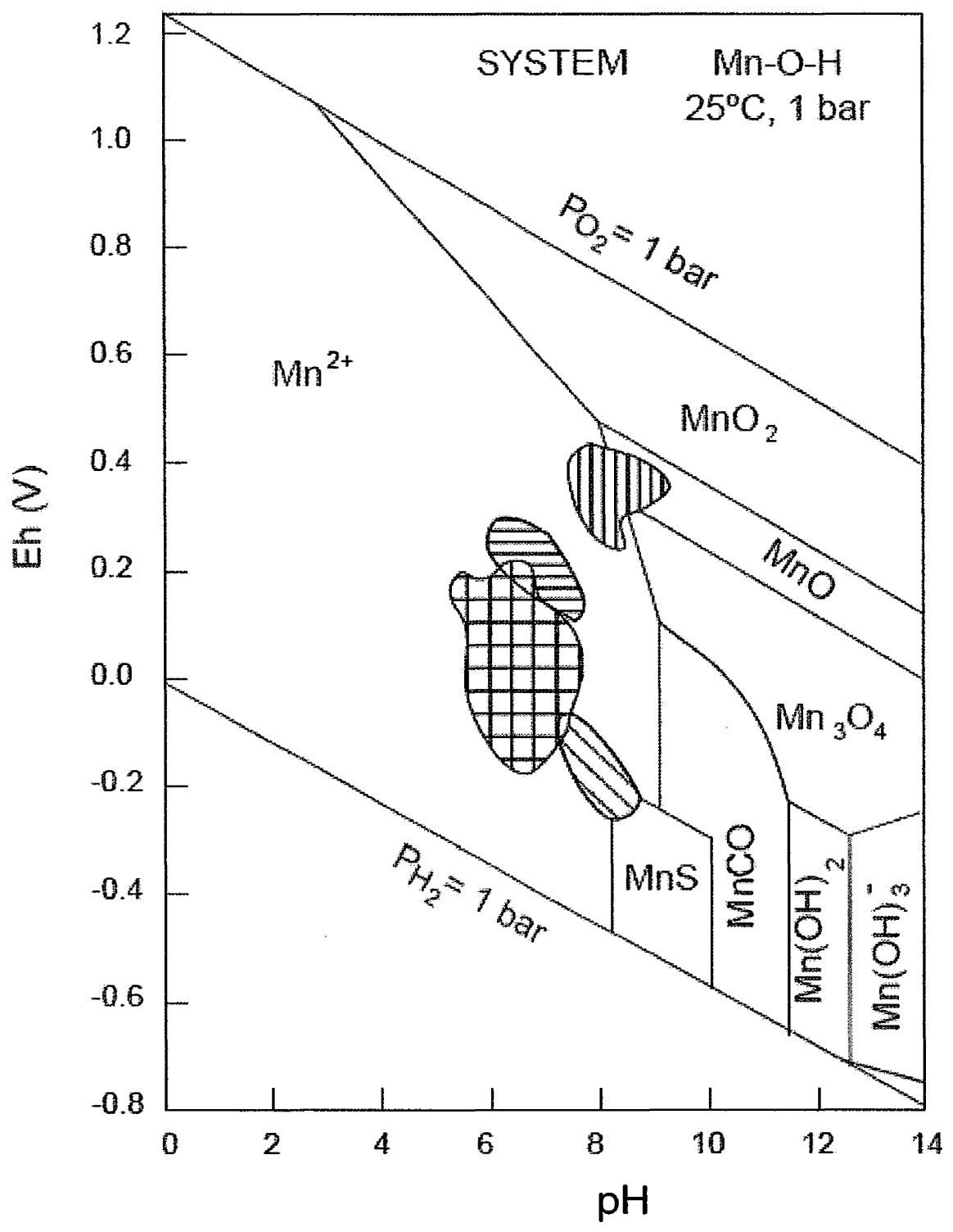

Df Mangue 17 Marisma-Zostera 2 Marisma-Spartina

Figura 4.20 - Diagrama de estabilidade para as diferentes formas de Mn (Modificado de Brookins, 1988) 


\subsubsection{Comportamento geoquímico do Mercúrio.}

O conteúdo de mercúrio obtido em cada fração tanto no solo de manguezal como nas marismas é apresentado na Tabela 4.9 e nas Figuras 4.21 e 4.22. No caso das marismas galegas somente foi estudado um único ponto de amostragem (Figura 4.22), embora os resultados para a extração seqüencial tenham sido similares para ambas as situações.

A concentração mais elevada correspondeu à fração $\mathrm{F} 2$, tanto nos solos de marismas como nos de manguezal, seguida da F1, F6 e F3. A concentração para as frações F4 e F5 apresentou-se abaixo do limite de detecção do equipamento $\left(0,061 \mathrm{mg} \mathrm{l}^{-1}\right)$.

Tabela 4.9. Concentração do $\mathrm{Hg}\left(\eta\right.$ mol.g ${ }^{-1}$ ) obtido para as diferentes frações nos solos de manguezais. $\mathrm{LD}=$ menor ao limite de detecção

\begin{tabular}{llll}
\hline & Máximo & Mínimo & media \pm sd \\
\hline F1 & 8,21 & $<$ LD & $1,83 \pm 1,87$ \\
F2 & 61,28 & 0,61 & $19,37 \pm 16,7$ \\
F3 & 0,61 & $<$ LD & $0,61 \pm 0,01$ \\
F4 & $<$ LD & $<$ LD \\
F5 & $<$ LD & $<$ LD & $<$ LD \\
F6 & $<$ LD & 0,01 & $1,37 \pm 1,51$ \\
\hline
\end{tabular}

Os resultados mostram claras diferenças, comparado aos que tem sido obtidos em trabalhos anteriores, realizados tanto em sedimentos como em solos de marismas. Nestes trabalhos tem sido evidenciado que o $\mathrm{Hg}$ é um dos elementos que se incorporam na fração pirítica com maior facilidade, apresentando valores de piritização (DTMP-Hg) superiores aos do Fe (para mais detalhe ver Huerta-Díaz \& Morse, 1992, Morse \& Luther, 1999). Estes autores encontraram um grau de piritização para o $\mathrm{Hg}$ superior ao $90 \%$ e para valores de piritização do Fe, inferiores a 20\%. Morse \& Luther (1999) explicam esta rápida piritização em função de sua afinidade pelo sulfeto e à maior 
estabilidade do $\mathrm{HgS}$, em comparação com a mackinawita (FeS), de modo que o $\mathrm{Hg}$ pode deslocar o Fe no FeS, de acordo com a reação:

$$
\mathrm{Hg}^{2+}+\mathrm{FeS} \Leftrightarrow \mathrm{HgS}+\mathrm{Fe}^{2+}
$$

Uma vez formado o HgS, este se torna muito estável e só pode ser extraído de maneira eficiente com ácido nítrico (Huerta-Díaz \& Morse, 1990, Di Toro et al., 1990, Morse \& Luther, 1999, Bloom et al., 2003). Os trabalhos anteriormente citados calculam o DTMP-Hg aplicando a equação 2, utilizando como fração reativa a extraída com $\mathrm{HCl}$ 1M (Huerta-Díaz \& Morse, 1990, 1992, Morse \& Luther, 1999) e como fração pirítica a extraída com o ácido nítrico (fração F6). Neste sentido, determinou-se o Hg solúvel com $\mathrm{HCl} 1 \mathrm{M}$ para os solos do manguezal do rio Crumahú (T1P1), do rio Irirí (P28), do canal da COSIPA (P2) e da Ilha do Cardoso (P2), obtendo-se valores muito baixos, estando a maior parte dos casos abaixo do limite de detecção. Utilizando estes valores como $\mathrm{Hg}$ reativo, a piritização do $\mathrm{Hg}$ estaria em torno de $100 \%$, já que o $\mathrm{Hg}$ solúvel em $\mathrm{HCl}$ foi da ordem de 30 vezes inferior ao $\mathrm{Hg}$ pirítico (Figura 4.21).

No entanto, se considerarmos como forma reativa a somatória $\sum \mathrm{F} 1, \mathrm{~F} 2, \mathrm{~F} 3, \mathrm{~F} 4$, que recolhe o metal reativo associado aos oxihidróxidos de Fe pouco cristalinos (HuertaDíaz et al., 1998), os valores de piritização são inferiores a $10 \%$ devido às elevadas concentrações obtidas para a fração F2.

Por outra parte cabe questionar: por que se obtêm valores de Hg tão elevados nas frações iniciais. Em primeiro lugar há que se ter em conta a advertência realizada por autores como Nirel \& Morel (1990), a respeito do uso da extração seqüencial. Estes autores criticam o uso indiscriminado da extração seqüencial aplicada aos elementos traço sem que haja sido validada para a maior parte destes e quando seus comportamentos geoquímicos possam ser muito diferentes entre si. Um dos elementos mais polêmicos é o mercúrio, para o qual não há ainda uma extração seqüencial bem definida (ver, por exemplo, Sladek \& Gustin, 2003; Bloom et al., 2003). Em nosso caso, a extração seqüencial aplicada necessita de um passo para extrair, especificamente a 
fração do elemento associada à matéria orgânica, que é de especial interesse para o $\mathrm{Hg}$, levando-se em conta a conhecida afinidade do $\mathrm{Hg}$ por esta fração do solo.

O esquema de extração empregado também não permite quantificar a quantidade de $\mathrm{Hg}$ elementar, o qual pode estar presente nestes solos se for levado em conta, o diagrama de estabilidade das formas de $\mathrm{Hg}$ de acordo com as condições Eh-pH (Figura 4.23). Na Figura 4.23 observa-se que a quase totalidade das amostras se situam no campo de estabilidade do $\mathrm{Hg}$ elementar e em menor medida no campo do $\mathrm{HgS}$, somente nas marismas pode aparecer a forma $\mathrm{HgO}$. A formação de $\mathrm{Hg}$ elementar pode ocorrer nestes ambientes como resultado da transformação realizada por bactérias anaeróbicas facultativas, processo que é mais intenso em meios anaeróbios (como o manguezal) do que em meios aeróbios (Spangler et al., 1973, Ramamoorthy et al., 1982, Weber et al., 1998). Também deve ter em conta que se trata de um meio com elevada concentração do íon cloreto, com o qual o $\mathrm{Hg}$ tende a formar complexos fortes. Portanto, diante destas variáveis é possível quue além do Hg elementar estejam presentes no meio, formas de mercúrio como $\mathrm{Hg}(\mathrm{OH}) \mathrm{Cl}, \mathrm{HgCl}_{3}^{-}$(Adriano, 2001).

O Hg elementar costuma ser determinado em uma extração paralela por meio de pirólise, aquecendo a amostra a temperaturas que oscilam entre 80 a $180^{\circ} \mathrm{C}$. No entanto, com o aquecimento, também são volatilizadas quantidades importantes de outras formas de $\mathrm{Hg}$ como $\mathrm{HgCl}_{2}$ (Eganhouse et al, 1978, Sladek \& Gustin, 2003; Bloom et al., 2003). Diante da falta de um método de extração seqüencial que inclua o $\mathrm{Hg}$ elementar em um dos passos e tendo em conta que uma fração do $\mathrm{Hg}$ total pode estar na forma de $\mathrm{Hg}$ elementar, foi realizado um ensaio aplicando a extração seqüencial e também a extração com $\mathrm{HCl} 1 \mathrm{M}$ a várias amostras de $\mathrm{Hg}$ elementar (Suprapur Merk). O objetivo foi estabelecer se esta forma pode ser dissolvida com os extratores empregados. 

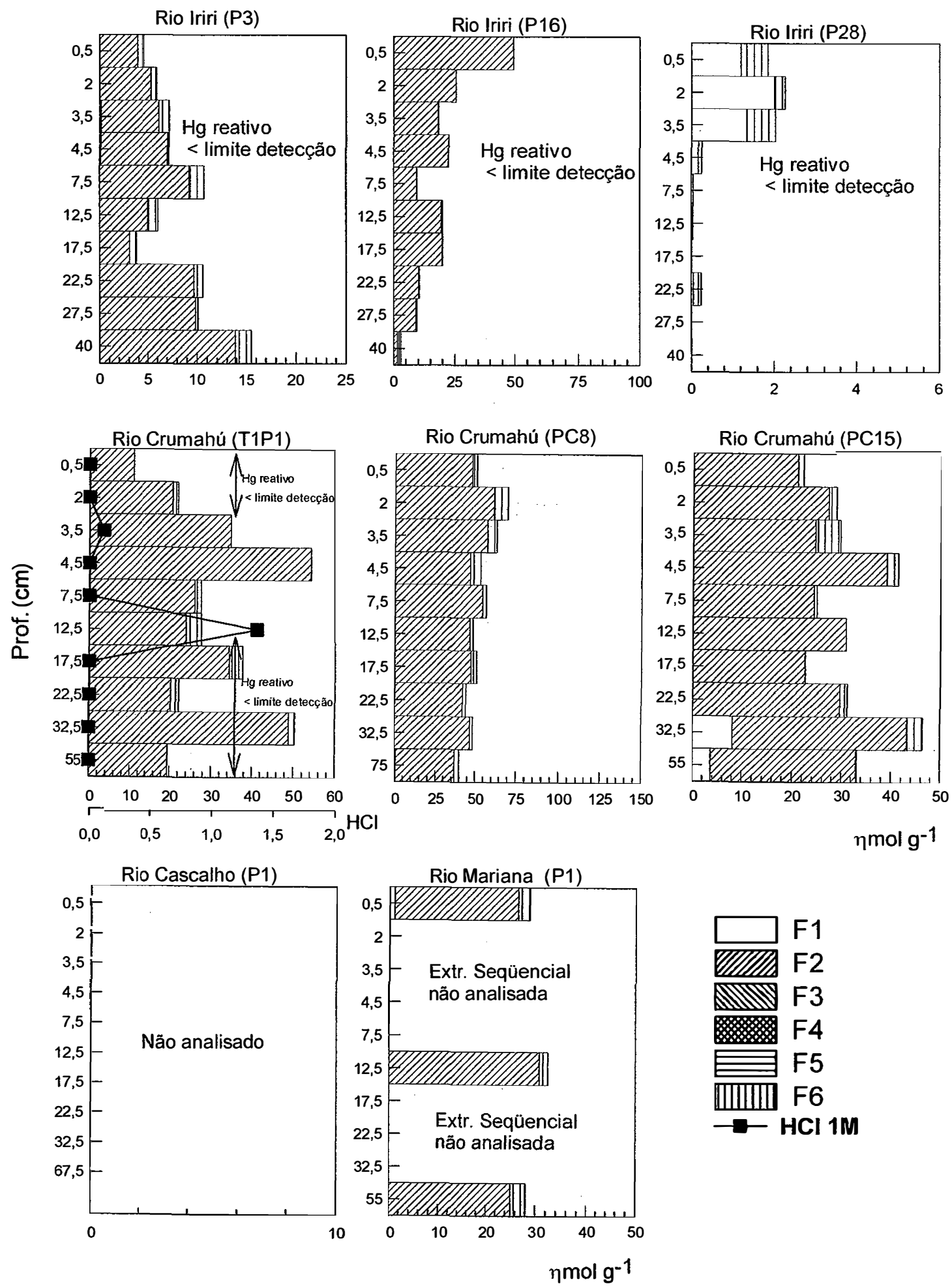

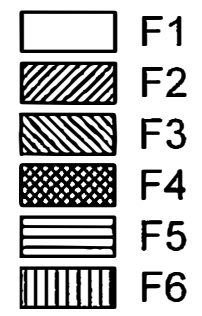

$\mathrm{HCl} 1 \mathrm{M}$

Figura 4.21a - Distribuição do Hg nas diferentes frações geoquímicas consideradas 

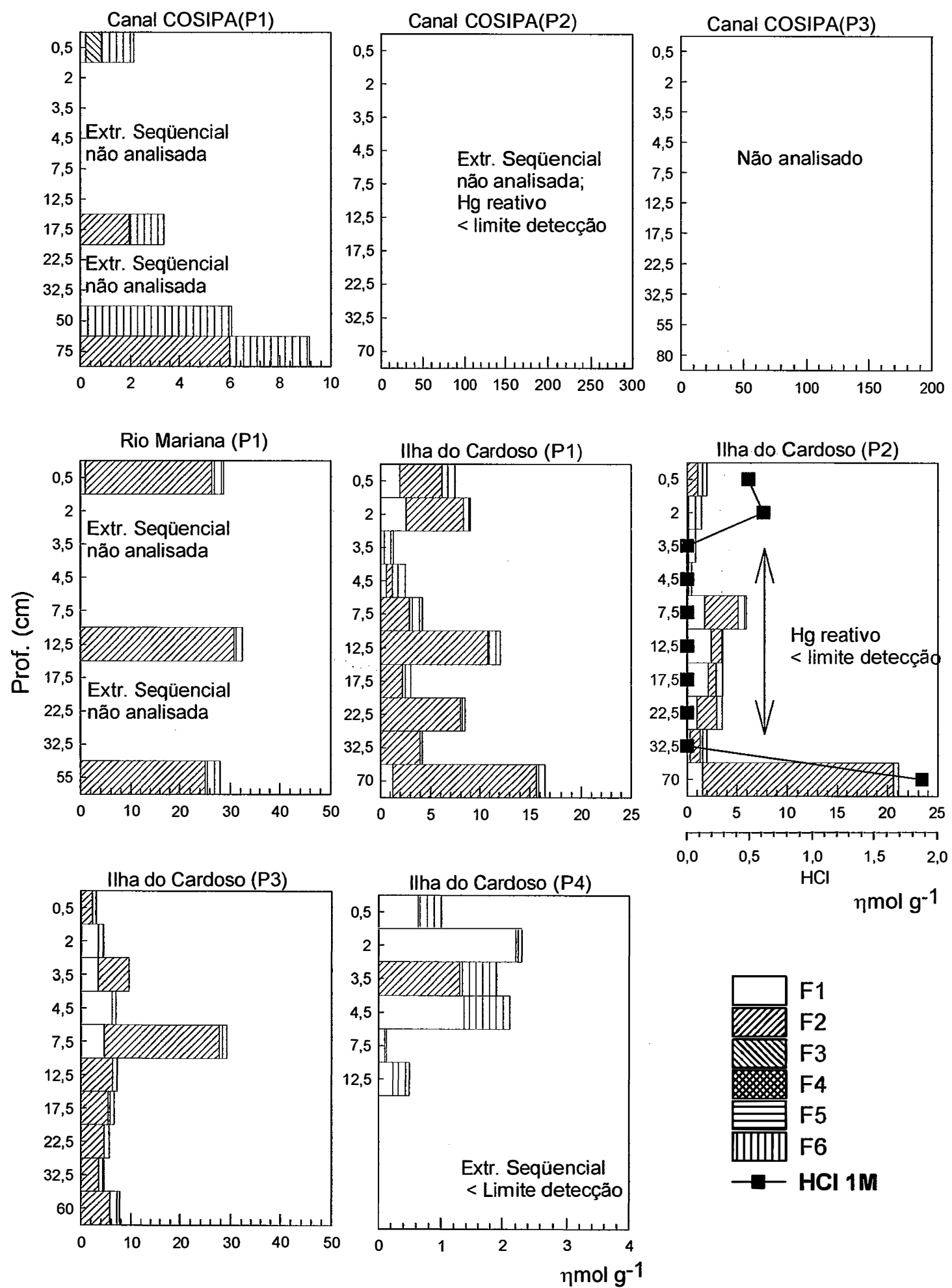

Figura 4.21b - Distribuição do Hg nas diferentes frações geoquímicas consideradas 
Os resultados indicam que praticamente a totalidade do $\mathrm{Hg}$ elementar é extraída no último passo (fração F6), quando se aplica o ácido nítrico concentrado, resultados que estão de acordo com os obtidos por Bloom et al. (2003). Entretanto é necessário indicar que neste ensaio não foi aplicado nem entre a fração F5 e F6 no ataque com HF 10M, nem com $\mathrm{H}_{2} \mathrm{SO}_{4}$, da forma como se faz com a amostra de solo. Mesmo assim, também se encontrou uma concentração de $93,0 \pm 17,8 \mu \mathrm{g} \cdot \mathrm{kg}^{-1}$, na fração $\mathrm{F} 1,30 \pm 4,3 \mu \mathrm{g} \cdot \mathrm{kg}^{-1}$ na $\mathrm{F} 2,15,0 \pm 11,4 \mu \mathrm{g} \cdot \mathrm{kg}^{-1}$ na F3 e $85 \pm 0,10 \mu \mathrm{g} \cdot \mathrm{kg}^{-1} \mathrm{em} \mathrm{HCl} \mathrm{1M}$, enquanto que nas frações F4 e F5 a concentração apresentou-se abaixo do limite de detecção. Em função destes resultados, podemos considerar que se a concentração de $\mathrm{Hg}$ total nestes solos já é por si só baixa (no geral inferior a $0,60 \mathrm{mg} \cdot \mathrm{kg}^{-1}$ ), maior o será na fração de $\mathrm{Hg}$ elementar, porque esta, apesar de ser pouco solúvel, pode ter sido extraída nas duas primeiras frações. Além disso, o fato de que na fração F6 dos solos estudados não apareçam quantidades elevadas de $\mathrm{Hg}$, pode ser devido a que este se perca por volatilização durante os passos $\mathrm{F} 4$ e $\mathrm{F} 5$, no qual a amostra é aquecida a $96^{\circ} \mathrm{C}$ e $75^{\circ} \mathrm{C}$, respectivamente, ou pelo ataque ácido ( $\mathrm{HF} 10 \mathrm{M} \mathrm{e} \mathrm{H}_{2} \mathrm{SO}_{4}$ concentrado) que se realiza antes de proceder à extração com ácido nítrico nas amostras de solo. 


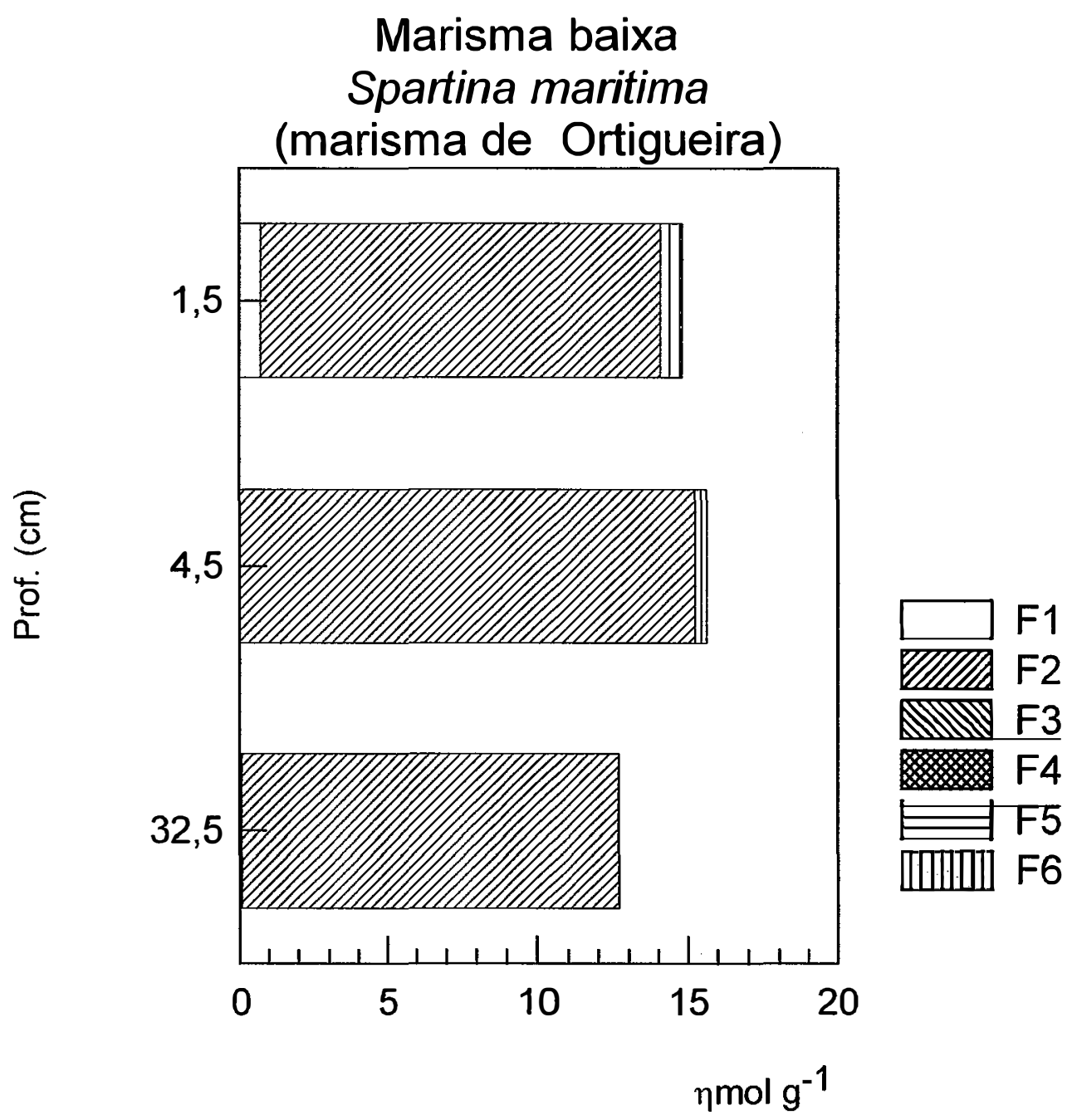

Figura 4.22 - Distribuição do $\mathrm{Hg}$ nos solos de marisma nas diferentes frações geoquímicas consideradas 


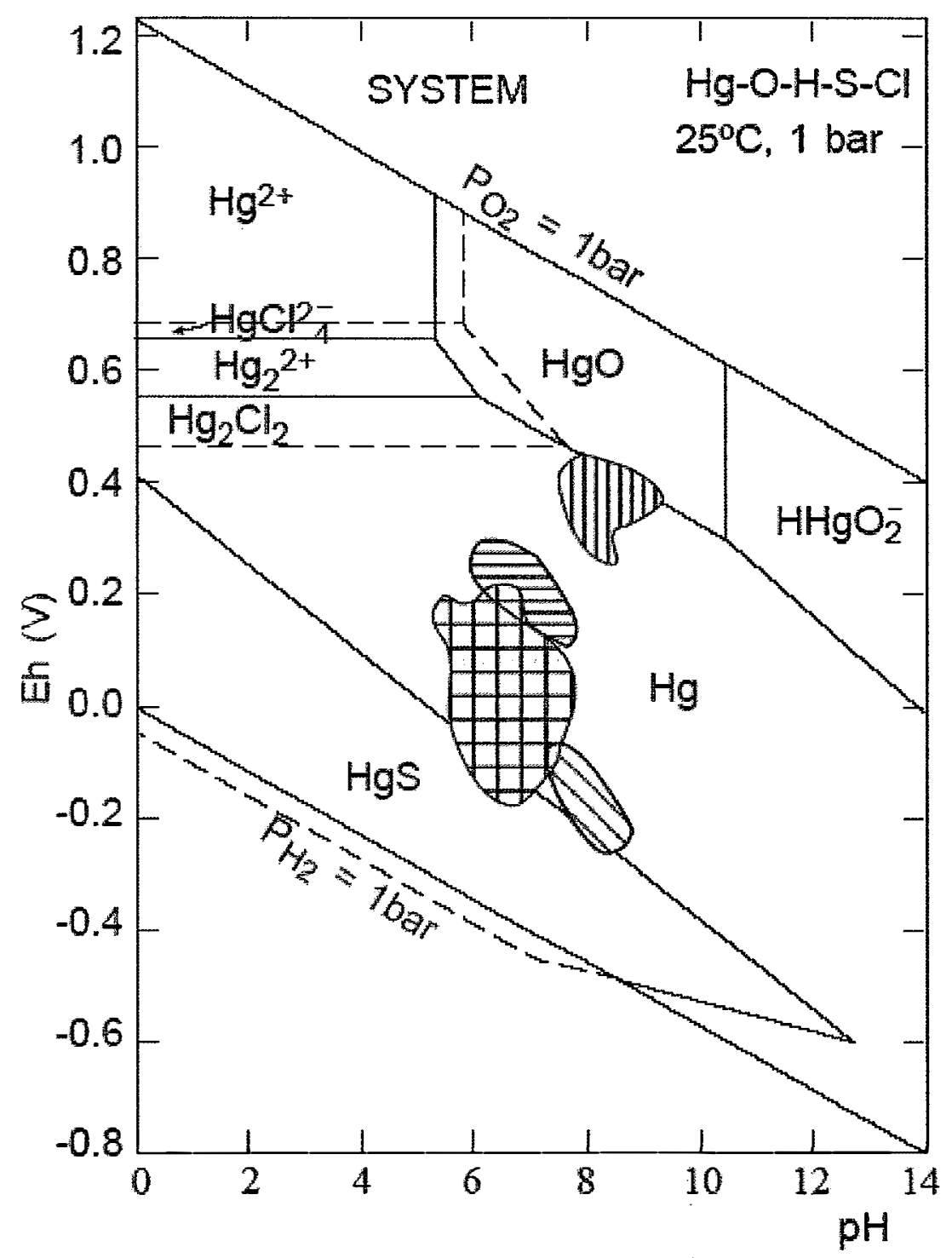

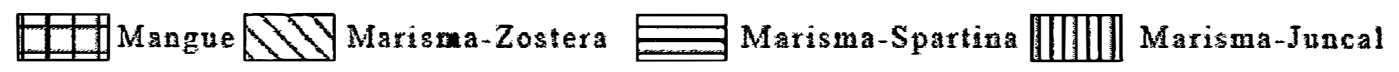

Figura 4.23 - Diagrama de estabilidade para as diferentes formas de Hg (Modificado de Brookins, 1988)

Portanto, o $\mathrm{Hg}$ que se extrai na $\mathrm{F} 6$ deve ser $\mathrm{Hg}$ associado à fração pirítica ou então $\mathrm{Hg}$ associado à matéria orgânica residual que permanece depois do ataque com ácido sulfúrico. As correlações altamente significativas encontradas entre o $\mathrm{Hg}$ da fração 
F6 e o $S$ total $\left(r_{s}=0,569, p<0,001 n=92\right)$ e o $C$ orgânico $\left(r_{s}=0,437, p<0,001, n=92\right)$ corroboram esta hipótese.

Levando em consideração a bibliografia, pode ser que a fração F2 seja capaz de extrair quantidades significativas de $\mathrm{Hg}$ associado a compostos orgânicos (Lechler et al., 1997). Esta última idéia também se apóia no fato de que a fração $F 2$ mostrou correlação altamente significativa com o $C$ orgânico $\left(r_{s}=0,763, p<0,001 n=70\right)$, enquanto que isto não aconteceu com a fração $F 1$.

Também pode ser considerado que os resultados obtidos neste trabalho contribuam para o melhor entendimento das formas que se encontra o $\mathrm{Hg}$ nos solos de manguezais e sobre o comportamento geoquímico desse elemento em tais tipos de solos. Assim sendo, por exemplo, num estudo realizado em sedimentos da Bahia de Sepetiba (RJ), após realizar uma extração seqüencial na qual se extrai o $\mathrm{Hg}$ trocável com $\mathrm{HCl}$ 0,5 $\mathrm{N}$, o Hg associado aos oxihidróxidos de Fe de baixa cristalinidade com hidroxilamina e Fe cristalino com ditionito, "encontrou-se que a somatória destas frações é muito reduzida, menos do $5 \%$ do $\mathrm{Hg}$ total. Os autores concluíram que a maior parte do $\mathrm{Hg}$ presente era residual encontrando-se associado aos silicatos ou à fração pirítica (Marins et al., 1998). Comparando os resultados obtidos neste trabalho com a bibliografia, infere-se que uma parte importante do $\mathrm{Hg}$ poderia encontrar-se como $\mathrm{Hg}$ elementar e outra como $\mathrm{Hg}$ associado à fração orgânica, frações estas que não devem considerar-se refratárias devido a que podem ser facilmente volatilizadas, oxidadas ou metiladas. A metilação do Hg também é um aspecto importante que deve ser abordado em trabalhos futuros e que podem contribuir para fortalecer os resultados aqui obtidos, no sentido de que as formas metiladas poderiam incorporar-se às frações F1 e F2.

\subsubsection{Comportamento geoquímico do Crómio}

A concentração de crómio nas diferentes frações está indicada nas Tabelas $4.10 \mathrm{e}$ 4.11 assim como nas Figuras 4.24 e 4.25. Os resultados obtidos indicam que este elemento se encontra preferencialmente associado aos oxihidróxidos de Fe e, bem menos, à fração pirítica e carbonatos. A fração trocável mostrou os valores mais baixos 
encontrados na maior parte das amostras, estando todas abaixo do limite de deteç̧ão $\left(7,1 \mu \mathrm{g} .1^{-1}\right)$.

Tabela 4.10. Concentração do $\mathrm{Cr}\left(\eta m o l . g^{-1}\right)$ obtido para as diferentes frações nos solos de manguezais. $\mathrm{LD}=$ inferior ao limite de detecção

\begin{tabular}{llll}
\hline & Máximo & Mínimo & media \pm sd \\
\hline F1 & 17,47 & $<$ LD & $3,30 \pm 3,30$ \\
F2 & 257,2 & $<$ LD & $52,30 \pm 51,30$ \\
F3 & $<$ LD & $15,43 \pm 7,86$ \\
F4 & 36,12 & 7,64 & $23,86 \pm 11,7$ \\
F5 & 71,08 & 3,89 & $66,48 \pm 53,1$ \\
F6 & 225,8 & 0,85 & $57,7 \pm 65,35$ \\
\hline
\end{tabular}

Os estudos realizados acerca do comportamento geoquímico do crómio em meios sedimentares marinhos são dedicados, na maioria dos casos, a solos de marismas ou de fundos oceânicos, sendo poucos os trabalhos realizados até o presente momento em solos de manguezais (Smillie, 1981, Rai et al., 1989, Calvert \& Pedesen, 1993, HuertaDíaz \& Morse, 1992, Otero et al. 2000, Otero \& Macías 2002a). Conforme os resultados obtidos em trabalhos anteriores, o crómio se caracteriza como um elemento que mostra um comportamento diferenciado em comparação com a maior parte dos elementos traço bivalentes os quais, em meios anóxicos, tendem a formar sulfetos insolúveis. Assim sendo, o grau de piritização encontrado para o crómio, na maior parte dos casos, não superou os 20\% (para mais detalhe ver Otero \& Macías, 2002b). Valores similares foram encontrados neste trabalho para os solos de marisma (Tabela 5.7). 

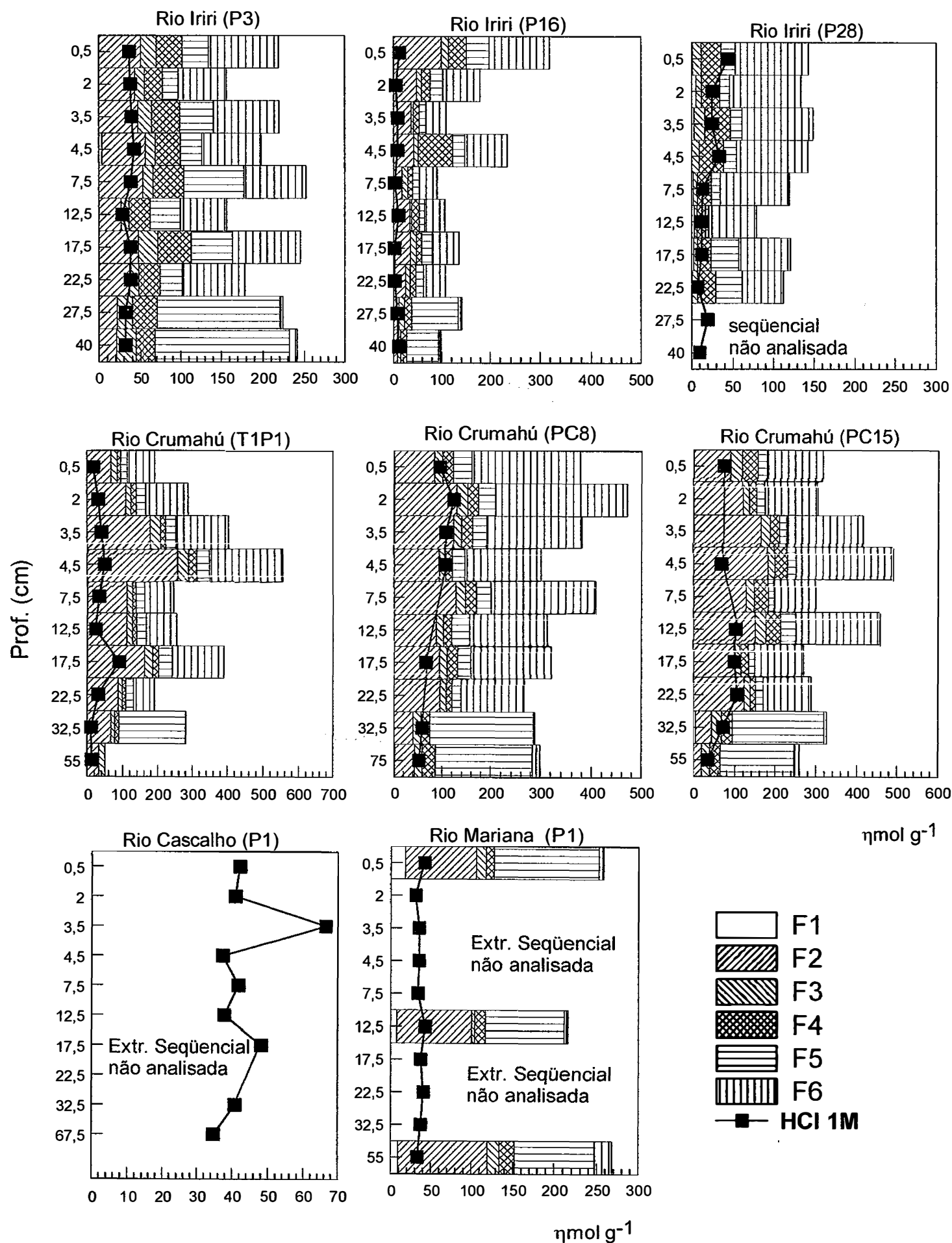

ๆmol g-1
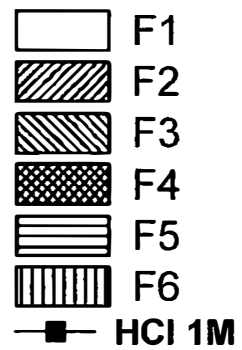

Figura 4.24a - Distribuição do Cr nas diferentes frações geoquímicas consideradas 

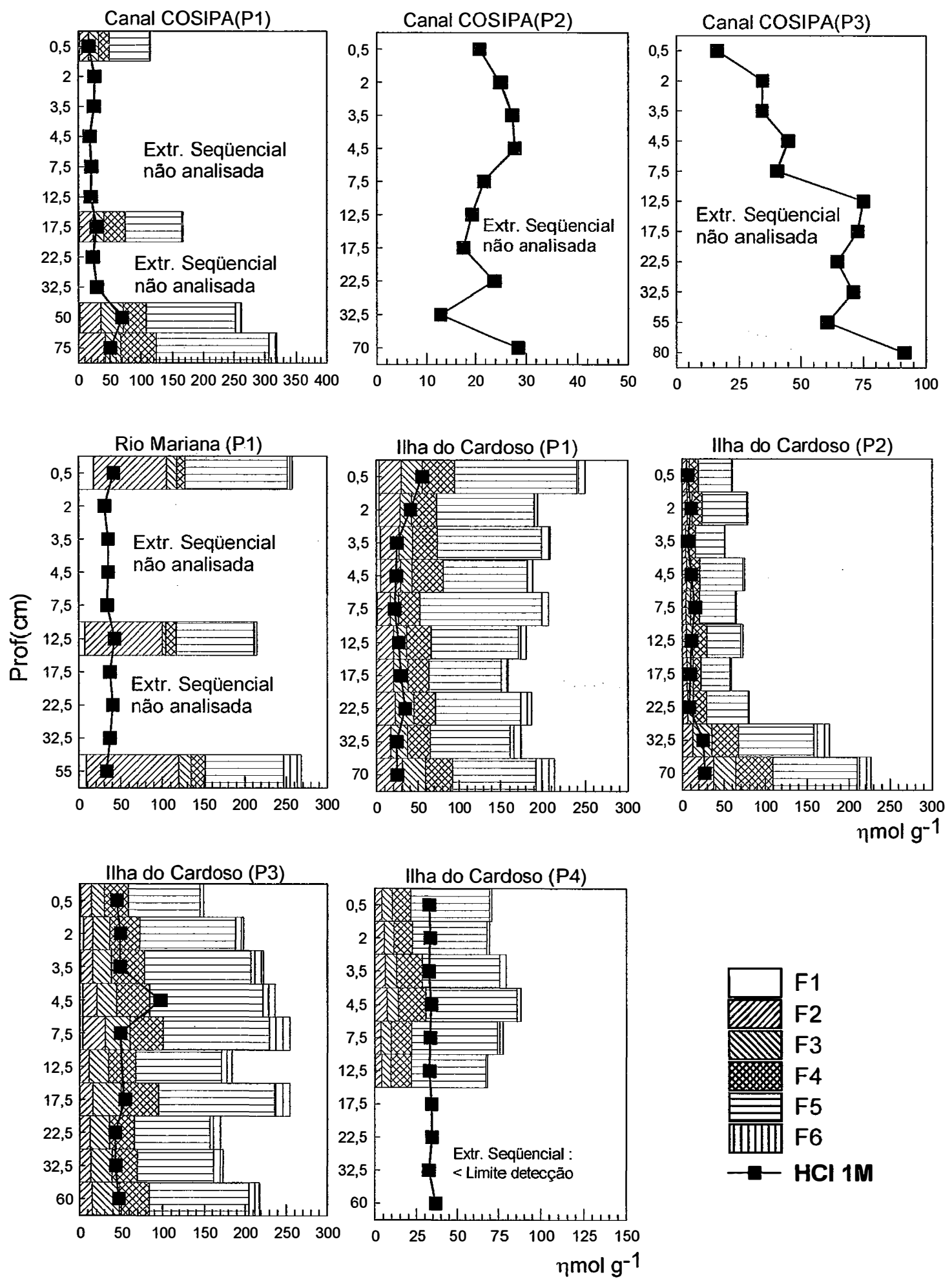

Figura 4.24b - Distribuição do Cr nas diferentes frações geoquímicas consideradas 
Tabela 4.11. Concentração do $\mathrm{Cr}\left(\eta m o l . \mathrm{g}^{-1}\right)$ obtido para as diferentes frações nos solos de marisma. $\mathrm{LD}=$ menor ao limite de detecção

\begin{tabular}{llll}
\hline & Máximo & Mínimo & media \pm sd \\
\hline F1 & $<$ LD & $<$ LD & $<$ LD \\
F2 & $<$ LD & $<$ LD & $<$ LD \\
F3 & 379,3 & 136,0 & $253,0 \pm 70,4$ \\
F4 & 291,2 & 144,7 & $207,4 \pm 35,8$ \\
F5 & 391,5 & 165,9 & $259,8 \pm 59,3$ \\
F6 & 45,90 & 13,70 & $21,60 \pm 7,90$ \\
\hline
\end{tabular}

A reduzida incorporação do crómio na fração pirítica pode estar relacionada com o fato de que se trata de um metal trivalente $\left(\mathrm{Cr}^{3+}\right)$ de modo que os sulfetos que este elemento constitui são muito instáveis (Smillie, 1989). Em meios anóxicos o crómio aparece associado aos oxihidróxidos de $\mathrm{Fe} / \mathrm{Mn}$ e à matéria orgânica, ou ainda pode precipitar como hidróxido de $\mathrm{Cr}\left(\mathrm{Cr}(\mathrm{OH})_{3} ;(\mathrm{Cr}, \mathrm{Fe})(\mathrm{OH})_{3}\right)$ (Rai et al., 1989, Eary \& Rai, 1989, Otero et al. 2001). 

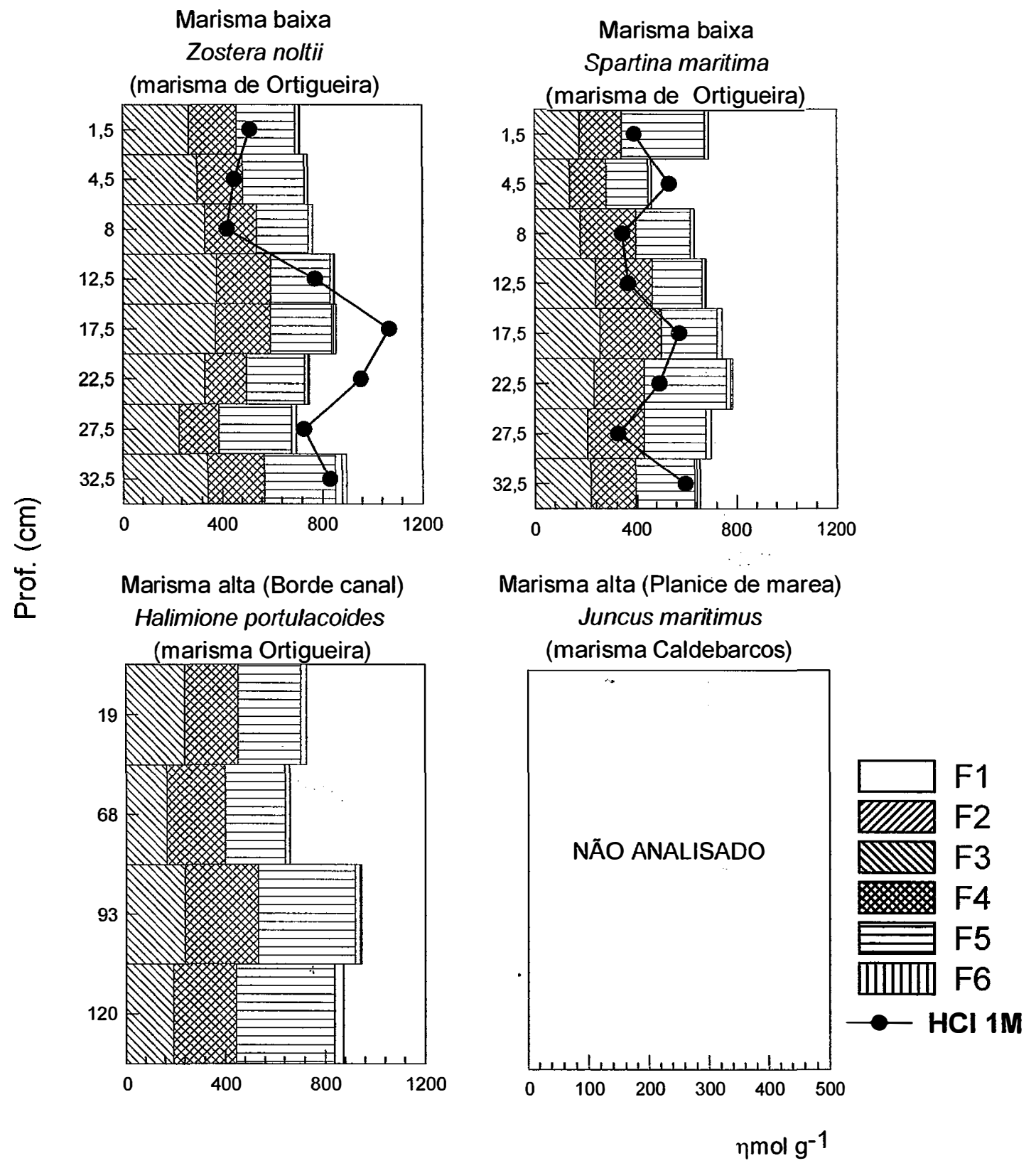

Figura 4.25 - Distribuição do $\mathrm{Cr}$ nos solos de marisma nas diferentes frações geoquímicas consideradas

Uma fração importante que costuma aparecer é a associada à fração residual, como por exemplo, em zonas de rochas ultrabásicas e básicas onde o crómio forma parte de alguns minerais primários (p. ex cromita) ou em silicatos secundários nos que se incorpora através de substituições isomórficas com o Fe ou com o Mg (Kiratli \& Erguin, 
1996). Neste sentido, nos solos das marismas de Ortigueira, foram encontradas partículas com alto conteúdo de $\mathrm{Cr}$ e $\mathrm{Fe}$, o que provavelmente pode ser uma cromita (Figura 4.26). A presença deste mineral na região estudada é freqüente, principalmente, no entorno geológico da zona que é constituído, em parte, por peridotitas serpentinizadas com concentrações de crómio que costumam oscilar entre 1000 e $10000 \mathrm{mg} \mathrm{kg}{ }^{-1}$ (Quintás-Mosteiro, 1997). Por este motivo, a somatória de todas as frações nos solos da marisma de Ortigueira foi muito superior ao mesmo tipo de valores obtidos nos manguezais e também aos dos valores médios encontrados para os sedimentos superficiais das rías da Galícia (Carral et al., 1995) (Figuras 4.24 e 4.25).

Tabela 4.12. Variação do grau de piritização do Cr (DTMP-Cr, \%) segundo a fração reativa considerada $(\mathrm{n}=148)$

\begin{tabular}{|c|c|c|c|}
\hline Fração reativa & $\mathrm{HCl} 1 \mathrm{~N}$ & $\sum \mathrm{F} 1 \rightarrow \mathrm{F} 4$ & $\sum F 1 \rightarrow F 5$ \\
\hline \multicolumn{4}{|c|}{ Mangue } \\
\hline Media \pm sd & $44,1 \pm 30,2$ & $28,6 \pm 22,2$ & $22,4 \pm 21,6$ \\
\hline Máximo & 93,6 & 78,0 & 73,16 \\
\hline Mínimo & 3,40 & 1,30 & 0,42 \\
\hline \multicolumn{4}{|c|}{ Marisma } \\
\hline Media \pm sd & $4,53 \pm 2,4$ & $4,51 \pm 1,38$ & $2,88 \pm 0,77$ \\
\hline Máximo & 12,4 & 7,91 & 5,15 \\
\hline Mínimo & 1,64 & 2,65 & 7,77 \\
\hline
\end{tabular}



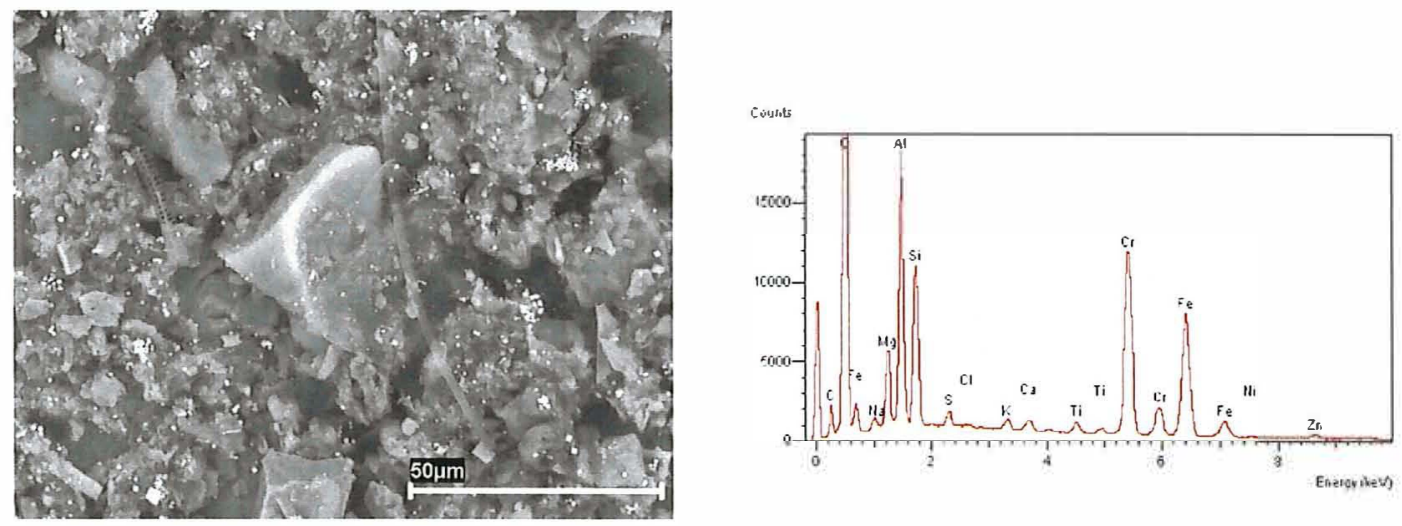

\section{$\mathrm{Cr}$}

$\mathrm{Fe}$
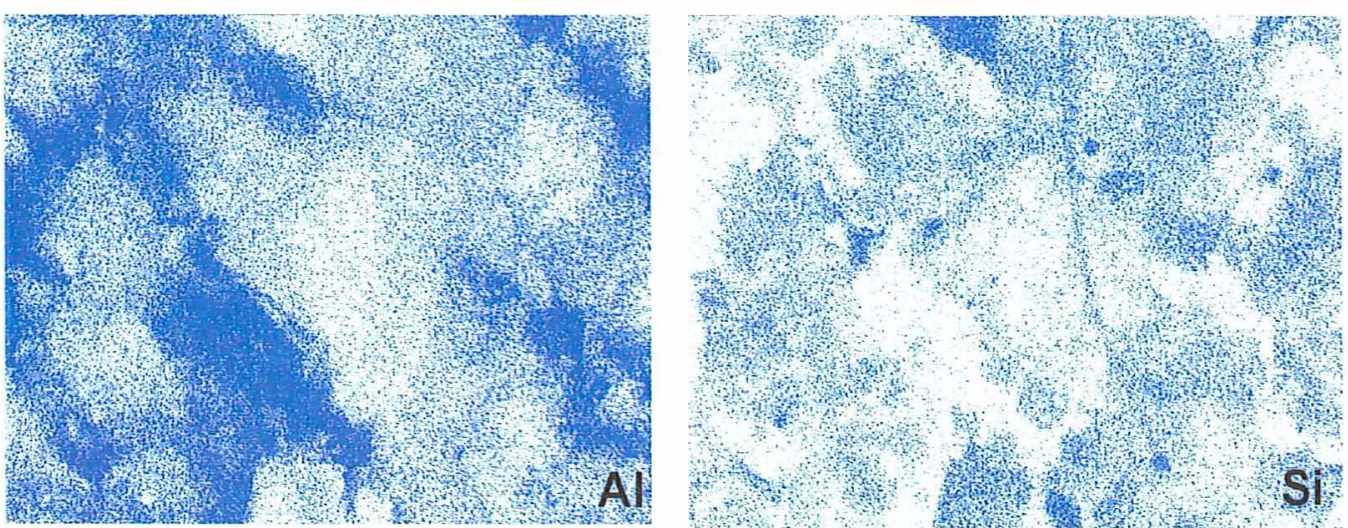

Figura 4.26 - Microfotografia (MEV) e analise elementar (EDS) de uma partícula rica em $\mathrm{Cr}$ (possivelmente cromita, $\mathrm{FeCr}_{2} \mathrm{O}_{4}$ ) encontrada nos solos da marisma de Ortigueira 


\subsubsection{Comportamento geoquímico do Níquel.}

A concentração do níquel em cada uma das frações é apresentada em detalhe na Figura 4.27 para os solos de manguezais e na Figura 4.28 para solos de marisma. Nas Tabelas 4.13 e 4.14 são apresentados os valores médios, máximos e mínimos encontrados para este elemento no manguezal e na marisma respectivamente.

Tabela 4.13. Concentração do Ni $\left(\eta m o l . g^{-1}\right)$ obtido para as diferentes frações nos solos de manguezais. $\mathrm{LD}=$ menor ao limite de detecção

\begin{tabular}{llll}
\hline & Máximo & Mínimo & media \pm sd \\
\hline F1 & 65,10 & $<$ LD & $12,18 \pm 14,9$ \\
F2 & 152,2 & $<\mathrm{LD}$ & $17,38 \pm 13,1$ \\
F3 & 74,66 & 0,10 & $18,56 \pm 13,8$ \\
F4 & 123,1 & 0,16 & $23,05 \pm 24,3$ \\
F5 & 99,80 & 0,58 & $37,37 \pm 25,0$ \\
F6 & 190,5 & 0,08 & $31,88 \pm 42,3$ \\
\hline
\end{tabular}

Os resultados mostram que o níquel se encontra predominantemente associado aos oxihidróxidos de $\mathrm{Fe} / \mathrm{Mn}$, correspondendo à somatória das frações F3, F4 e F5, mais de $50 \%$ do Ni extraído nas 6 frações nos solos de manguezal e mais de 70\% nos solos de marisma. Estes valores evidenciam a importância desta fase geoquímica no controle da concentração de muitos elementos traço no solo, apesar do ambiente fortemente redutor (Schoer, 1985). Por outro lado, também é necessário destacar a importância da fração pirítica que representa a segunda em importância no manguezal e a quarta nos solos de marisma. 
Tabela 4.14. Concentração do $\mathrm{Ni}\left(\eta \mathrm{mol} . \mathrm{g}^{-1}\right)$ obtido para as diferentes frações nos solos de marisma ao limite de detecção

\begin{tabular}{llll}
\hline & Máximo & Mínimo & media \pm sd \\
\hline F1 & 232,2 & $<$ LD & $125,3 \pm 90,7$ \\
F2 & 378,2 & $<$ LD & $114,9 \pm 78,5$ \\
F3 & 655,0 & 35,39 & $433,3 \pm 218$ \\
F4 & 1005 & 31,45 & $684,9 \pm 365$ \\
F5 & 631,4 & 32,76 & $368,1 \pm 169$ \\
F6 & 649,3 & $<$ LD & $319,0 \pm 161$ \\
\hline
\end{tabular}

Os resultados aqui encontrados estão de acordo com os obtidos em trabalhos anteriores realizados em sedimentos de fundos oceânicos e em solos de marismas (Huerta-Díaz \& Morse, 1992, Otero et al., 2001, Otero \& Macías, 2002a). Nos trabalhos já mencionados, o níquel se incorpora à fração pirítica progressivamente, à medida que aumenta o DOP, devido à cinética de reação do Ni com os sulfetos ser mais lenta que a do próprio $\mathrm{Fe}$ (Morse \& Luther, 1999), motivo pelo qual seu grau de piritização é inferior. Neste sentido, a correlação significativa encontrada entre o Fe e o Ni pirítico colabora com esta idéia $\left(r_{s}=0,434, p<0,001, n=135\right)$.

Por outro lado, o total de $\mathrm{Ni}$ extraído nas seis frações reflete uma maior concentração deste elemento nos solos das marismas da ría de Ortigueira que nos solos da marisma de Caldebarcos e dos manguezais. O motivo é o mesmo que foi exposto no caso do crómio. O níquel também aparece em concentrações elevadas nas peridotitas serpentinizadas presentes no entorno geológico destas marismas (para mais detalhe ver, Van Calsteren, 1978, Otero et al., 2001). No entanto, a mobilidade geoquímica do Ni é superior a do $\mathrm{Cr}$, devido ser encontrado em minerais facilmente alteráveis (clinopiroxênios, cloritas, crisotilo) porque já nas primeiras fases da alteração da rocha, se produz uma perda deste elemento. Por isso, nos solos das marismas o Ni aparece em quantidades muito inferiores aos do crómio associado à fração refratária (silicatos) (Otero et al., 2001). 

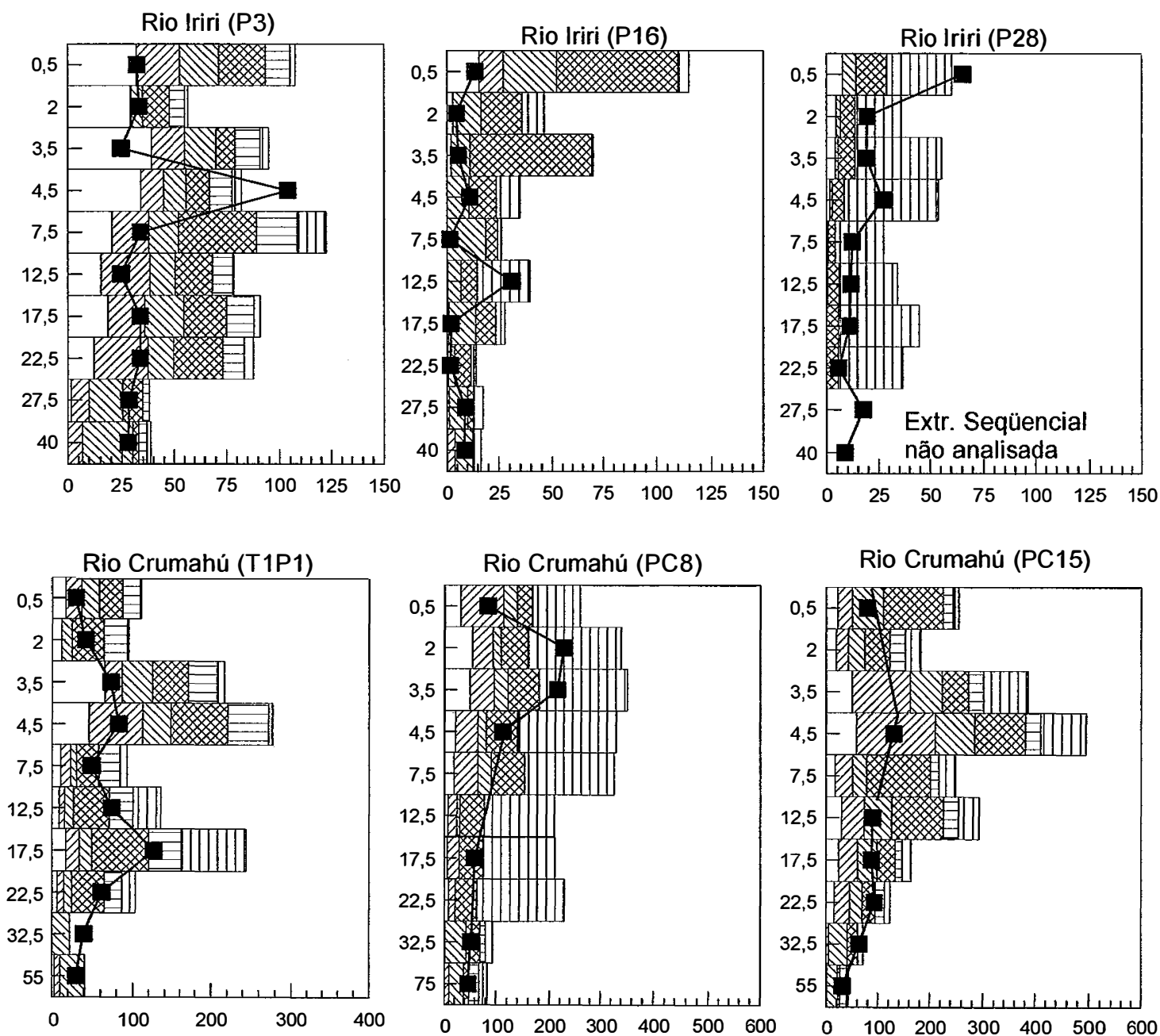

Rio Crumahú (PC15)
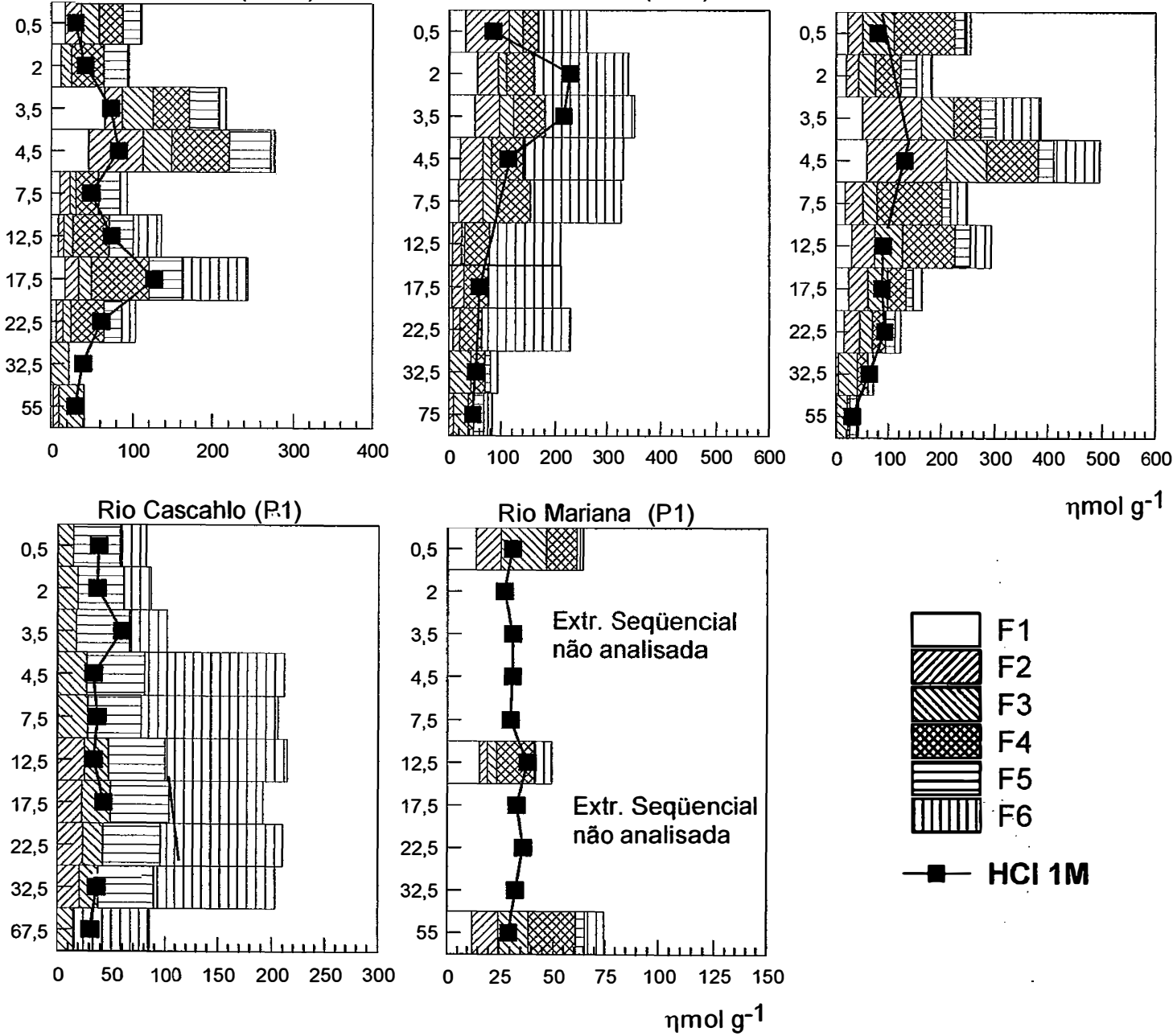

$\eta \mathrm{mol} \mathrm{g}-1$

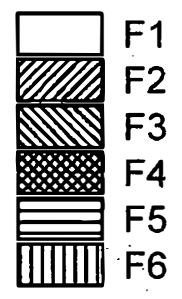

$\rightarrow-\mathrm{HCl} 1 \mathrm{M}$

Figura 4.27a - Distribuição do Ni nas diferentes frações geoquímicas consideradas 

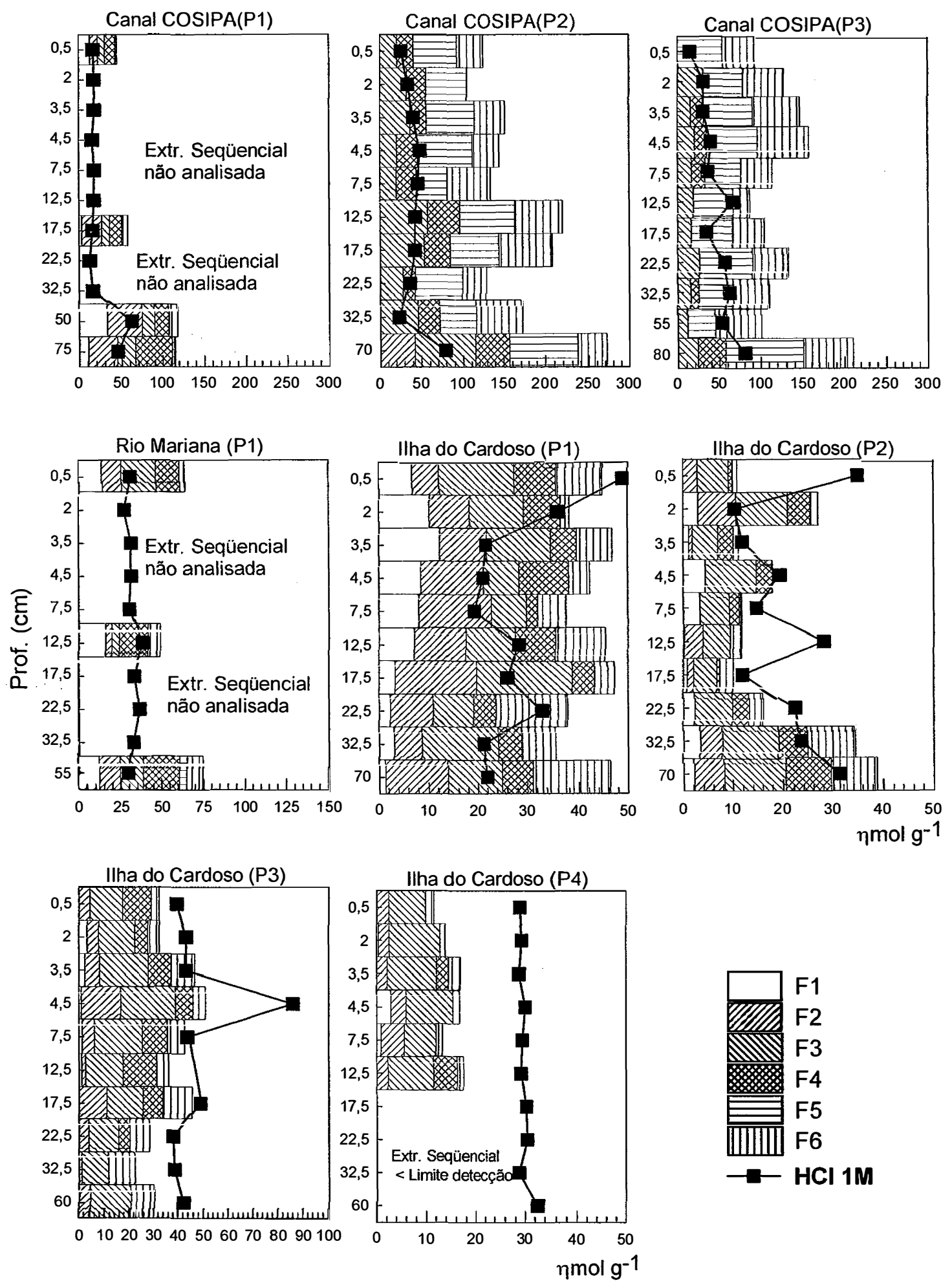

Figura 4.27b - Distribuição do Ni nas diferentes frações geoquímicas consideradas 

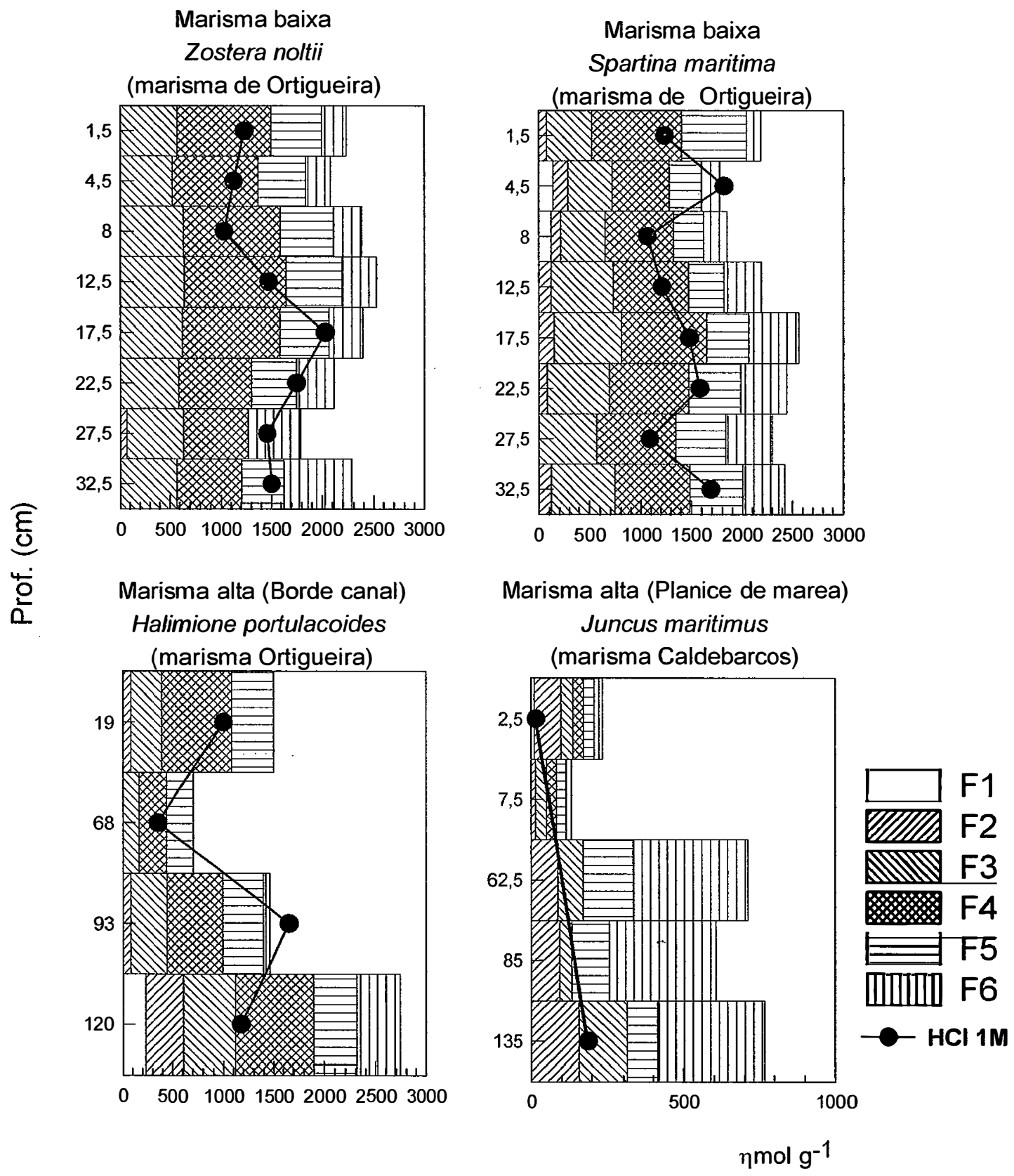

Figura 4.28 - Distribuição do Ni nos solos de marisma nas diferentes frações geoquímicas consideradas 


\subsubsection{Comportamento geoquímico do Cobre.}

Os principais componentes do solo que participam no controle dos metais nos solos são os oxihidróxidos de $\mathrm{Fe} / \mathrm{Mn}$, a matéria orgânica, os sulfetos e os carbonatos (Jenne, 1968). Já nos solos de manguezais e nos solos de marisma aqui estudados, a fração pirítica resultou ser especialmente relevante (Figuras 4.29, 4.30). De forma geral, esta fração representa para os solos de manguezais mais do que $44 \%$ do total do $\mathrm{Cu}$ extraído, valor muito mais alto do que as demais frações que apresentaram valores muito similares (Tabela 4.15). Os resultados novamente estão em consonância com os encontrados em trabalhos anteriores em solos de marisma e de sedimentos de fundos oceânicos (Huerta-Díaz \& Morse, 1992, Otero et al 20021, Otero \& Macías, 2002a). Estes autores encontraram que o $\mathrm{Cu}$ apresenta uma incorporação à fração pirítica similar à do Fe, apresentando graus de piritização similares ou inclusive ligeiramente superiores, devido à sua cinética de reação com os sulfetos, que é mais rápida, sendo possível à formação de sulfetos de $\mathrm{Cu}$ com ou sem $\mathrm{Fe}$. No entanto, a concentração de Fe reativo costuma ser 1000 vezes superior à do cobre (comparar Figuras 4.15, 4.16 com Figuras $4.29,4.30$ ), sendo mais provável a formação de sulfetos. A correlação altamente significativa encontrada entre o $\mathrm{Fe}$ e o $\mathrm{Cu}$ pirítico fortalece esta hipótese ( $\mathrm{rs}=0,891$, $\mathrm{p}<0,001, \mathrm{n}=100)$.

Tabela 4.15. Concentração do $\mathrm{Cu}\left(\eta \mathrm{mol} . \mathrm{g}^{-1}\right)$ obtido para as diferentes frações nos solos de manguezal

\begin{tabular}{llll}
\hline & Máximo & Mínimo & media \pm sd \\
\hline F1 & 116,0 & $<$ LD & $22,38 \pm 24,4$ \\
F2 & 71,81 & $<$ LD & $17,79 \pm 16,2$ \\
F3 & 115,70 & 0,30 & $21,32 \pm 26,3$ \\
F4 & 88,93 & 0,05 & $20,29 \pm 22,8$ \\
F5 & 109,7 & 0,02 & $23,26 \pm 22,5$ \\
F6 & 289,0 & 3,39 & $82,10 \pm 67,5$ \\
\hline
\end{tabular}



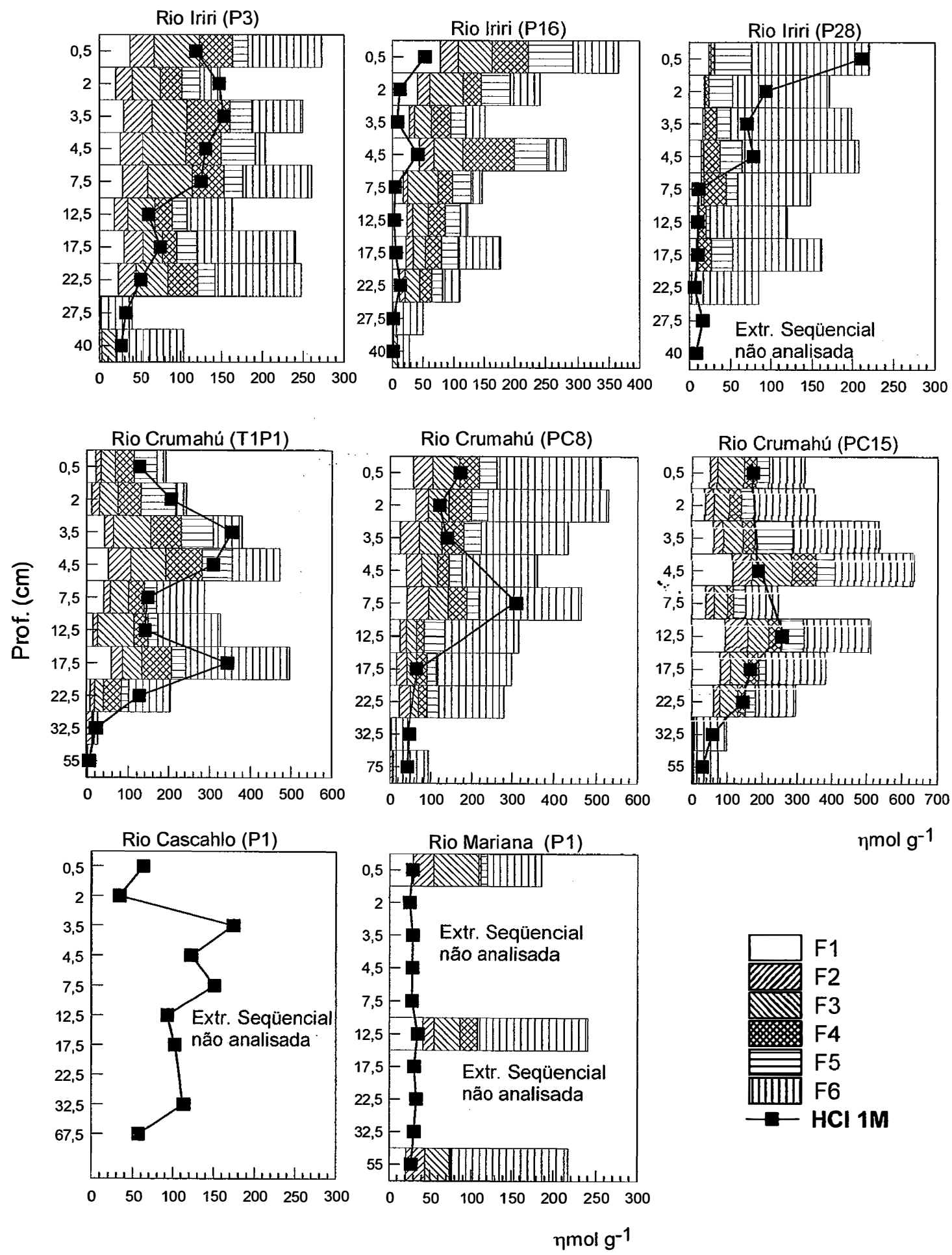

$\eta \mathrm{mol} \mathrm{g}^{-1}$
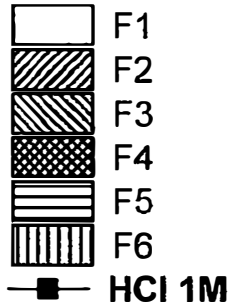

Figura 4.29a - Distribuição do Cu nas diferentes frações geoquímicas consideradas 

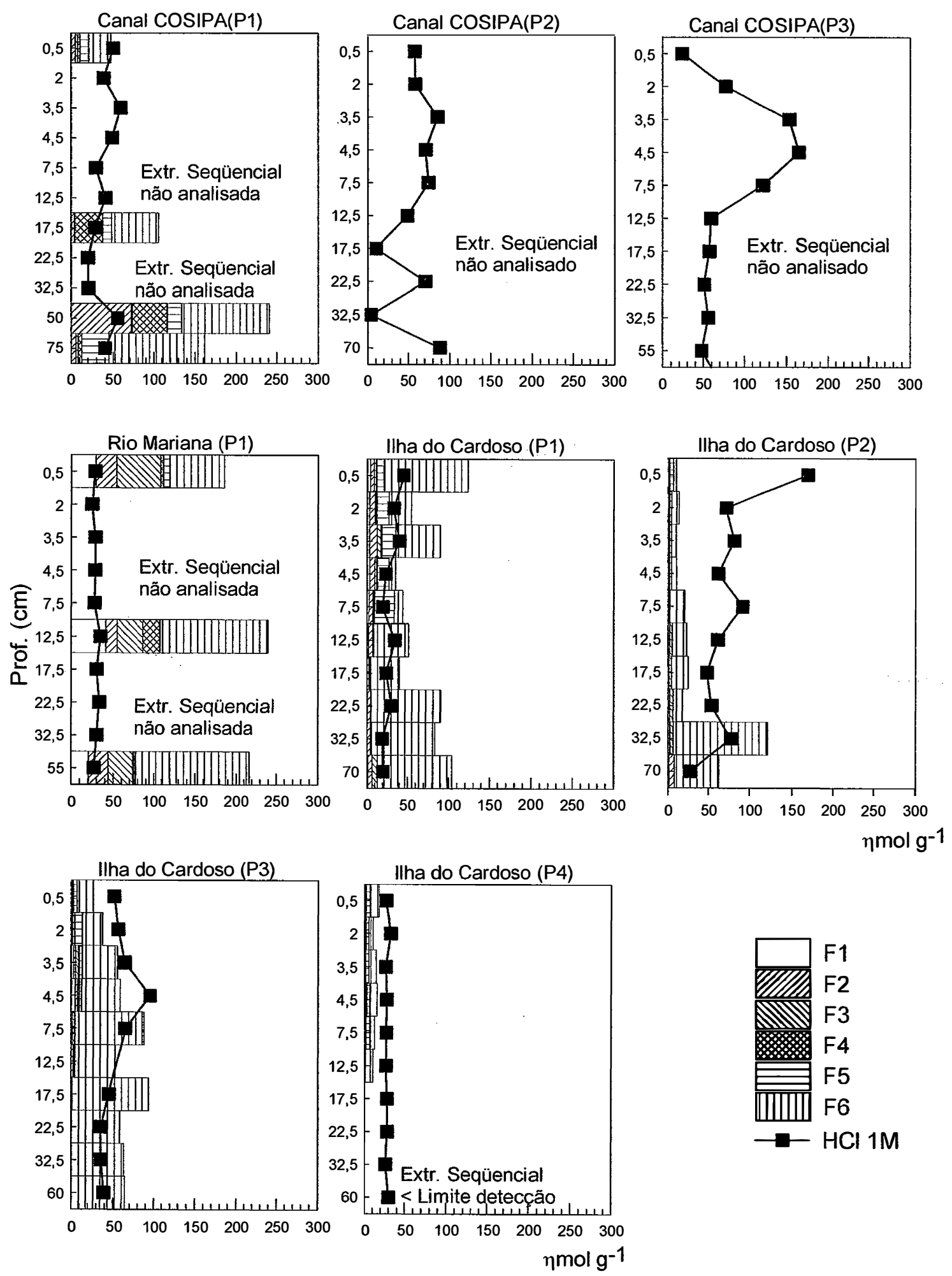

Figura 4.29b - Distribuição do Cu nas diferentes frações geoquímicas consideradas 


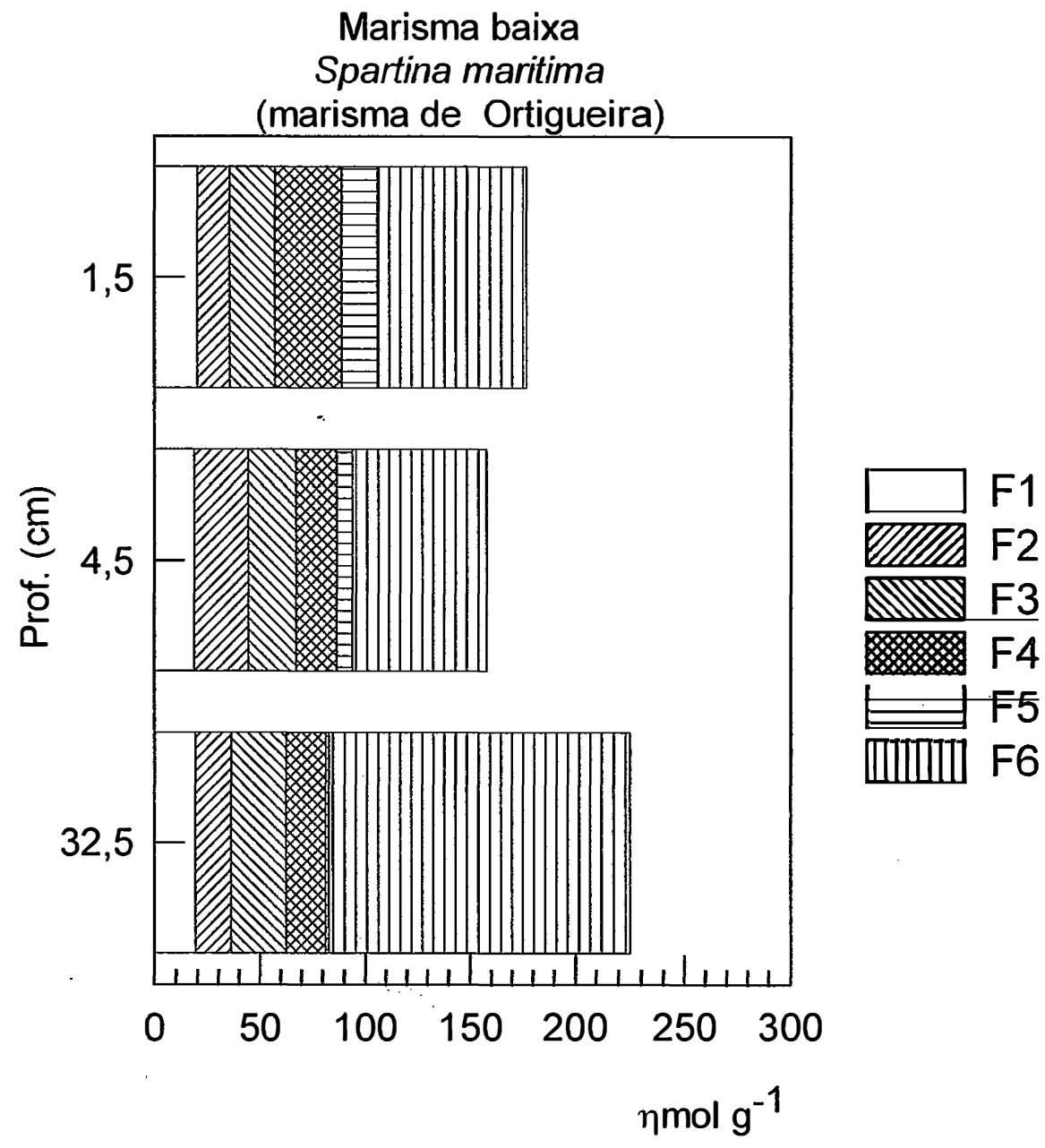

Figura 4.30 - Distribuição do $\mathrm{Cu}$ nos solos de marisma nas diferentes frações geoquímicas consideradas

\subsubsection{Comportamento geoquímico do Zinco.}

A distribuição do zinco nas frações consideradas está ilustrada nas Figuras $4.31 \mathrm{e}$ 4.32. O zinco se apresentou, em sua maioria, associado aos oxihidróxidos de Fe, fundamentalmente às formas menos cristalinas (F3, F4). As frações restantes apresentaram valores similares entre elas (Tabela 4.16). $\mathrm{O}$ aspecto mais destacável dos resultados obtidos é a reduzida incorporação deste elemento na fração pirítica num meio anóxico. Inclusive em alguns casos, o grau de piritização do $\mathrm{Zn}$ é inferior à do crómio. Entretanto, diferentemente do Cr que é considerado inerte na reação com os sulfetos, o 
Zn pode chegar a formar nos solos e nos sedimentos seus próprios sulfetos; tal como têm sido evidenciados em diversos trabalhos (Luther et al., 1980, Zaggia \& Zonta, 1997).

Tabela 4.16. Concentração do $\mathrm{Zn}\left(\eta m o l . \mathrm{g}^{-1}\right)$ obtido para as diferentes frações nos solos de marisma

\begin{tabular}{llll}
\hline & Máximo & Mínimo & media \pm sd \\
\hline F1 & 1300 & 0,65 & $73,15 \pm 164$ \\
F2 & 699,1 & 18,30 & $63,45 \pm 112$ \\
F3 & 698,7 & 18,30 & $148,6 \pm 121$ \\
F4 & 1475 & 24,22 & $237,11 \pm 285$ \\
F5 & 424,6 & 0,68 & $94,11 \pm 113$ \\
F6 & 423,5 & 3,48 & $60,16 \pm 73,3$ \\
\hline
\end{tabular}

A razão fundämental pela qual, tanto neste trabalho como nos trabalhos anteriores, tenha sido encontrado um baixo grau de piritização do $\mathrm{Zn}$, é devido aos sulfetos de $\mathrm{Zn}$ serem altamente solúveis em meio ácido, razão pela qual mesmo que se formem sulfetos de $\mathrm{Zn}$, estes se dissolveriam nas extrações das frações anteriores ou no ataque com $\mathrm{HF}$ ou ainda com o ácido sulfúrico que é aplicado previamente à extração da fração pirítica (Cooper \& Morse, 1998). Neste caso, o Zn que aparece na fração pirítica deve ser presumivelmente $\mathrm{Zn}$ co-precipitado com a pirita. A correlação altamente significativa entre Fe e $Z n$ pirítico sustenta esta idéia $\left(r_{s}=0,885, p<0,001, n=135\right)$. 

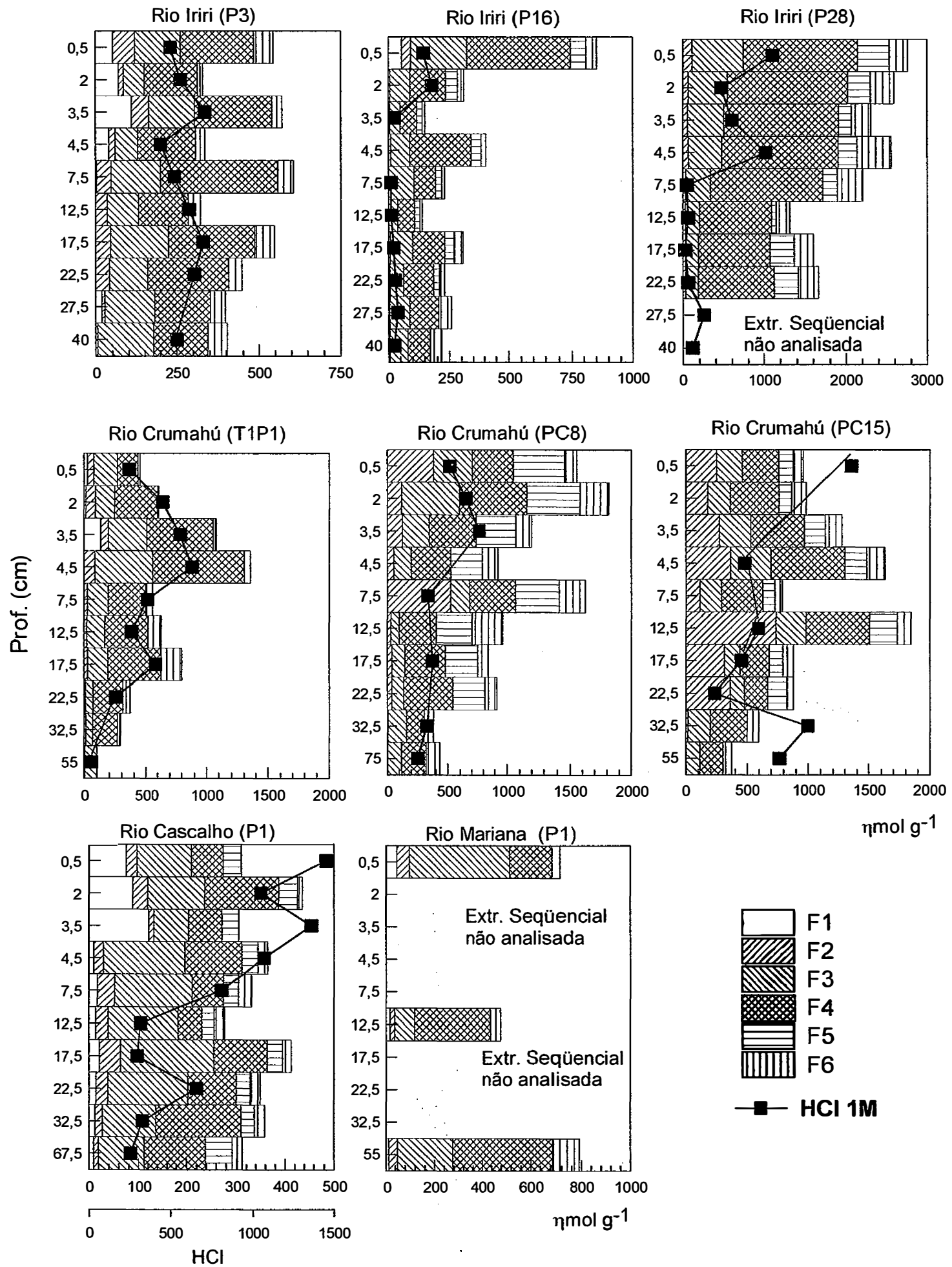

$\rightarrow-\mathrm{HCl} 1 \mathrm{M}$

Figura 4.31a - Distribuição do Zn nas diferentes frações geoquímicas consideradas 

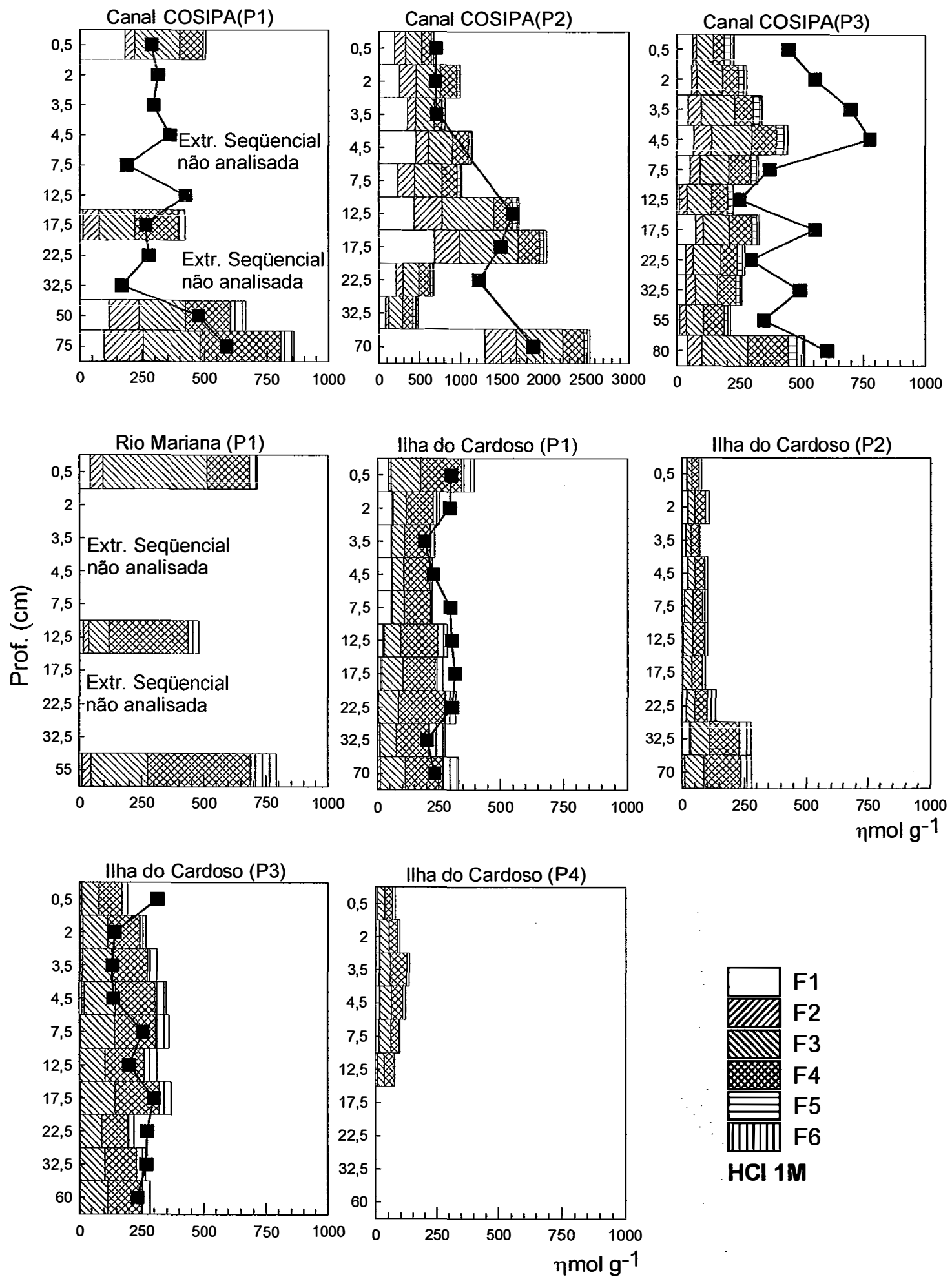

$\mathrm{HCl} 1 \mathrm{M}$

Figura 4.31b - Distribuição do Zn nas diferentes frações geoquímicas consideradas 


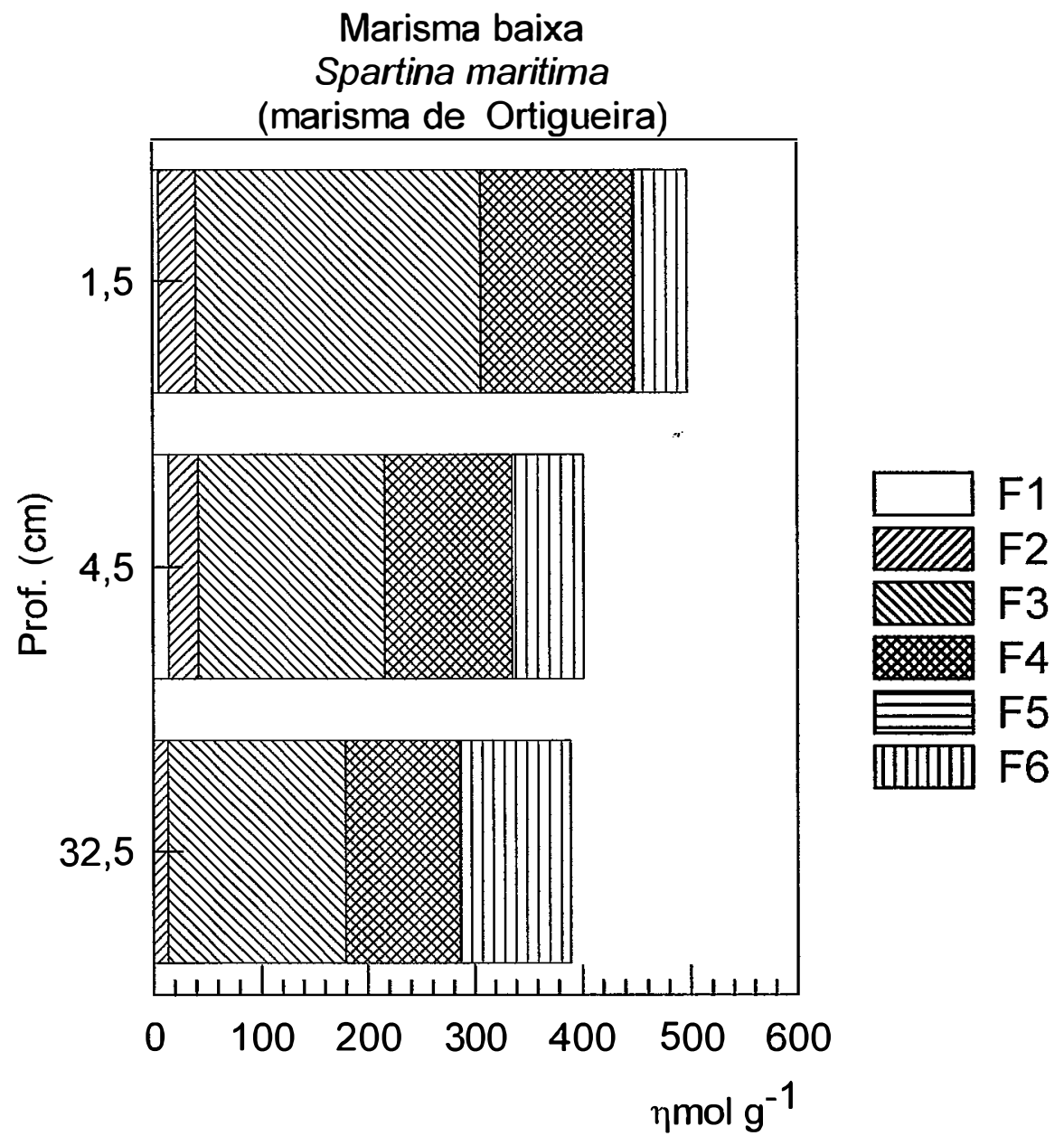

Figura 4.32 - Distribuição do $\mathrm{Zn}$ nos solos de marisma nas diferentes frações geoquímicas consideradas 


\section{CONCLUSÕES}

Foram estudados 15 perfis de solos de diferentes manguezais do Estado de São Paulo e 5 perfis de solos de marismas da Galícia (Espanha). Os resultados obtidos permitem extrair as seguintes conclusões:

1. As condições fisico-químicas dos solos de manguezais se caracterizaram por apresentar uma ampla variação em seu conteúdo em matéria orgânica, o pH situou-se próximo à neutralidade e as condições de oxidação-redução dominantes foram anóxicas.

2. Os solos das marismas apresentaram características similares às dos manguezais no conteúdo de matéria orgânica e no pH. No entanto, as condições redox apresentam uma maior faixa de variação, encontrando-se ambientes óxicos, subóxicos e anóxicos.

3. De acordo com os critérios vigentes da CETESB, os solos do manguezal do rio Irirí e do rio Cascalho apresentam-se poluídos por $\mathrm{Cr}$ e contaminados por $\mathrm{Ba}$; os do manguezal do rio Crumahú apresentam-se poluídos por $\mathrm{Ba}$, Mo e As; os do manguezal do rio Mariana apresentam-se poluídos por $\mathrm{Ba}$, $\mathrm{Mo}$, As e $\mathrm{Cr}$; os do manguezal do canal da COSIPA apresentam-se poluídos $\mathrm{Cu}$ e $\mathrm{Cr}$ e contaminados por Ba. Os solos dos manguezais da Ilha do Cardoso, não se apresentam poluídos ou contaminados, com exceção dos solos do manguezal do rio Jaguapariú, que apresentou uma contaminação pontual por Ba (perfil 1).

4. Comparando os solos dos manguezais e das marismas abordadas neste estudo, os das marismas apresentam poluição e ou contaminação mais acentuada que os do manguezais.Os solos da marisma de Pontevedra apresentam-se poluídos por Ni e 
$\mathrm{Cu}$ e contaminada por $\mathrm{As}, \mathrm{Zn}$ e $\mathrm{Pb}$. Os solos da marisma de Caldebarcos apresentam-se poluídos por As e Cr.

5. A piritização do $\mathrm{Fe}, \mathrm{Mn}$ e dos elementos traço considerados foi muito mais intensa nos solos de manguezais do que nos das marismas.

6. Independentemente do tipo de ambiente (marisma ou manguezal), a incorporação dos elementos traço à fração pirítica não depende unicamente das condições redox dos solos, mas também do comportamento geoquímico de cada elemento em particular. Ainda que todos os metais considerados tenham apresentado correlações significativas com o $\mathrm{Fe}$ pirítico, o grau de piritização foi muito diferente para cada um deles.

7. $\mathrm{O} \mathrm{Cu}$ apresentou um grau de piritização, similar ou inclusive superior ao do $\mathrm{Fe}$, seguido do Ni e do Mn. Em ambientes anóxicos, a concentração destes metais na fração pirítica pode chegar a superar a fração reativa.

8. $\mathrm{O} \mathrm{Cr}$ apresentou baixo grau de piritização, o que se explica por sua escassa reatividade com os sulfetos. Em meios anóxicos este elemento precipita como hidróxido ou se encontra associado à matéria orgânica do solo.

9. O baixo grau de piritização que foi encontrado para o $\mathrm{Zn}$ pode ser devido a um problema metodológico, já que o $\mathrm{ZnS}$ é solúvel em meio ácido pelo que deve ter havido dissolução desta forma nas frações anteriores à pirítica.

10. Os resultados obtidos para o $\mathrm{Hg}$ diferem dos obtidos na bibliografia. $\mathrm{O}$ grau de piritização encontrado foi muito baixo. Isto se deve a maior parte do $\mathrm{Hg}$ ser extraída na fração F2. Para este elementos são necessários mais estudos e aplicar novas técnicas de especiação que considerem o $\mathrm{Hg}$ elementar. 


\section{REFERÊNCIAS BIBLIOGRÁFICAS}

ACIESP. Glossário de Ecologia. São Paulo. Academia de Ciências do Estado de São Paulo. São Paulo: Secretaria de Tecnologia e Desenvolvimento Tecnológico, 1997. p.352. (Publicação ACIESP, 103).

ADRIANO, D.C. Trace elements in terrestrial environments. Biogeochemistry, bioavailability and risks of metals. 2 ed. New York: Springer, 2001. 867p.

ALLEN, H.E.; FU, G.; DENG, B. Analysis of acid-volatile sulfide (AVS) and simultaneously extracted metals (SEM) for the estimation of potential toxicity in aquatic sediments. Environmental Toxicology and Chemistry, v.12, p.1441-1453, 1993.

AQUINO, M. C. A importância biológica do mangue. Apicultura no Brasil, v.4, p.8, 1987.

AZEVEDO, A. (Coord.). A Baixada Santista - Aspectos Geográficos. 1. As bases físicas. São Paulo: EDUSP, 1965. 178p.

BARROS, F.; MELO, M.M.R.F.; CHIEA, S.A.C.; KIRIZAWA, M.; WANDERLEY, M.G.L.; JUNG-MENDAÇOLLI, S.L. Caracterização geral da vegetação e listagem das espécies ocorrentes. São Paulo: Instituto de Botânica, 1991. v.1., $184 \mathrm{p}$. 
BASS BECKING, L.G.M.; MOORE, D. Biogenic sulfides. Economic Geolology, v.56, p.243-250, 1961.

BECKETT, P.H.T. The use of extractants in studies on trace metals in soils, sewagwe sludges, and sludges-tratede soils. Advances in Soil Science, v.9, p.143-173, 1989.

BERNER, R.A. Sedimentary pyrite formation. American Journal Science, v.268, p.123, 1970.

BERNER, R.A. Sedimentary pyrite formation: An update. Geochimica Cosmochimica Acta, v.48, p.605-615, 1984.

BESCANSA, P.; ROQUERO, C. Characterization and classification of tidal marsh soils and plant communities in North-west Spain. Catena, v.17, p.347-355, 1990.

BLOOM, N. S.; PREUS, E.; KATON, J.; HILTNER, M. Selective extraction to assess the biogeochemically revelent fractionation of inorganic mercury in sediments. Analytica Chimica Acta, v.479, p.233-248, 2003.

BREEMEN, N.V.; BUURMAN, P. Soil formation. Dordrecht: Kluwer, 1998. 376p.

BROOKINS, D.G. Eh-pH diagrams for geochemistry. Berlin: Springer-Verlag, 1988. $176 \mathrm{p}$.

BRYAN, G.W.; LANGSTON, W.J. Bioavailability, accumulation and effects of heavy metals in sediments with special reference to United Kingdom estuaries: a review. Environmental Pollution, v.76, p.89-111, 1992. 
BURDIGE, D.J.; DHAKAR, S.P.; NEALSON, K.H. Effects of manganese oxide mineralogy on microbial and chemical manganese reduction. Geomicrobiology Journal, v.10, p.27-48, 1992.

BURDIGE, D.J. The biogeochemistry of manganese and iron reduction in marine sediments. Earth-Science Reviews, v.35, p.249-284, 1993.

CAETANO, M.; MADUREIRA, M.J.; VALE, C. Metal remobilisation during resuspension of anoxic contamined sediment: Short-term laboratory study. Water, Air, and Soil Pollution, v.143, p.23-40, 2003.

CAETANO, M.; FALCAO, M.; VALE, C.; BEBIANNO, M.J. Tidal flushing of ammonium, iron and manganese from inter-tidal sediment pore waters. Marine Chemistry, v.58, p.203-211, $1997^{\circ}$.

CALVERT, S.E.; PEDERSEN, T.F. Geochemistry of recent oxic and anoxic marine sediments: Implications for the geological record. Marine Geological, v.113, p.67$88,1993$.

CANFIELD, D.E.; THAMDRUP, B.; HANSEN, J.W. The anaerobic degradation of organic matter in Danish coastal sediments: Iron reduction, manganese reduction and sulfate reduction. Geochimica Cosmochimica Acta, v.57, p.3867-3883, 1993.

CARBAllEIRA, A.; DEVESA, C.; RETUERTO, R.; SANTILLÁN, E.; UCIEDA, F. Bioclimatologia de Galícia. A Coruña: Fundación Pedro Barrié de la Maza, 1983. v.1., 391p. 
CARDONA, P.; BOTERO, L. Soil characteristics and vegetation structure in a heavily deteriorated mangrove forest in the Caribbean Coast of Colombia. Biotropica, v.30, p.24-34, 1998.

CARRAL, E.; PUENTE, X.; VILLARES, R.; CARBALLEIRA, A. Background heavy metals levels in estuarine sediments and organisms in Galicia (northwest Spain) as determined by modal analysis. Science Total Environmental, v.172, 175-188, 1995.

CARVALHO, C.E.V.; LACERDA, L.D. Heavy Metals In The Guanabara Bay Biota: Why Such Low Concentrations?. CIENCIA E CULTURA. SOCIEDADE BRASILEIRA PARA O PROGRESSO DA CIÊNCIA, v.44, p.184-186, 1992.

CASKEY, W.H.; TIEDJE, J.M. The reduction of nitrate to ammonium in soils. Journal of General Microbiology, v.119, p.217-223, 1980.

CHESTER, R.; HUGHES, M. J. A chemical technique for the separation of ferromanganese minerals, carbonate minerals and adsorbed trace elements from pelagic sediments. Chemistry Geology, v.2, p. 249-262, 1967.

CHIU, C.Y.; CHOU, C.H. The distribution and influence of heavy metals in mangrove forests of the Tamshui Estuary in Taiwan. Soil Science and Plant Nutrition, v.37, p.659-669, 1991.

CINTRÓN, G.; SCHAEFFER-NOVELLI, Y. Introducción a la ecologia del manglar. Montevideo: Oficina regional de Ciencia y Tecnología de la Unesco para América Latina y el Caribe, 1983. 109p.

CLINE, J.E. Spectrophotometric determination of hydrogen sulfide in natural waters. Limnology and Oceanography, v.14, p.454-458, 1969. 
COMPANHIA DE TECNOlOgia E SANEAMENTO AMBIENTAL. Poluição das águas no estuário e baía de Santos. São Paulo: Companhia de Tecnologia e Saneamento Ambiental. Secretaria de Obras e do Meio Ambiente. Governo do Estado de São Paulo, 1978. v.1., 71p.

COMPANHIA DE TECNOLOGIA E SANEAMENTO AMBIENTAL. Poluição das águas no estuário e baía de Santos. São Paulo: Companhia de Tecnologia e Saneamento Ambiental, 1979. v.1., 71p. (Relatório Técnico CETESB).

COMPANHIA DE TECNOLOGIA E SANEAMENTO AMBIENTAL. Relatório de estabelecimento de valores orientadores para solos e águas subterrâneas no Estado de São Paulo. São Paulo: Companhia de Tecnologia e Saneamento Ambiental, 2001 a. 247p. (Relatório Técnico CETESB).

COMPANHIA DE TECNOLOGIA E SANEAMENTO AMBIENTAL. Sistema estuarino de Santos e São Vicente. São Paulo: Companhia de Tecnologia e Saneamento Ambiental, 2001 b. 178p. (Relatório Técnico CETESB).

COMPANHIA DE TECNOLOGIA E SANEAMENTO AMBIENTAL. Relatório de qualidade das águas litorâneas do estado de São Paulo: balneabilidade das praias 2003/ CETESB - São Paulo: CETESB, 2004. 183p.

CONNELL, W.E.; PATRICK, W.H. Sulfate reduction in soil: effects of redox potential and pH. Science, v.159, p.86-89, 1968.

COOPER, D.C.; MORSE, J.W. Extractability of metal sulfide minerals in acidic solutions: Application to environmental studies of trace metal contamination. Environmental Science and Technology, v.32, p.1076-1078, 1998. 
CORNWELL, J.C.; MORSE, J.W. The characterization of iron sulfide minerals in anoxic marine sediments. Marine Chemistry, v.22, p.193-206, 1987.

CORREIA, A.D.; COSTA, M.H. Effects of sediment geochemical properties on the toxicity of copper-spiked sediments to the marine amphipod Gammarus locusta. Science Total Environmental, v.247, p. 99-106, 2000.

DE LAUNE, R.D.; GRAMBRELL, R.P. Role of sedimentation in isolating metal contaminants in wetland environments. Journal of Environment Science Healt, v. 31, p.2349-2362, 1996.

DIRETORIA DE HIDROGRAFIA E NAVEGAÇÃO. Tábuas de marés. Ministério da Marinha. 1984.

DI TORO, D.M.; MAHONY, J.D.; HANSEN, D.J.; SCOTT, K.J.; HICKS, M.B.; MAYS, S.M.; REDMOND, M.S. Toxicity of cadmium in sediments: The role of acid volatile sulfide. Environmental Toxicology Chemistry, v.9, p.1489-1504, 1990.

DI TORO, D.M.; MAHONY, J.D.; HANSEN, D.J.; SCOTT, K.J.; CARLSON, A.R.; ANKLEY, J.T. Acid volatile sulfide predicts the acute toxicity of cadmium and nickel in sediments. Environmental Science and Technology, v.26, p.96-101, 1992.

EARY, L.E.; RAI, D. Kinetics of chromate reduction by ferrous ions. American Journal Science, v.289, p.180-213, 1989.

EGANHOUSE, R.P.; YOUNG, D. R.; JOHNSON, J.N. Geochemistry of mercury in Palos Verdes sediments. Environmental Science \& Technology, v.12, p.1151-1157, 1978. 
EHRLICH, H.L. Geomicrobiology. New York: Marcel Dekker, 1996. 719p.

ELDERFIELD, $\mathrm{H}$. Metal-organic associations in intersticial waters of Narragansett Bay sediments. American Journal Science, v.281, p.1021-1055, 1981.

EMPRESA BRASILEIRA DE PESQUISA AGROPECUÁRIA. Centro Nacional de Pesquisa de Solos. Levantamento de reconhecimento dos solos do Estado do Espírito Santo. Rio de Janeiro, 1978. p.370-379. (Boletim Técnico, 45).

EMPRESA BRASILEIRA DE PESQUISA AGROPECUÁRIA. Mapa pedológico do Estado de São Paulo: Legenda expandida / João Bertoldo de Oliveira, et al. Campinas: Instituto Agronômico; Rio de Janeiro: Embrapa-Solos, 1999. 64 p. mapa $14 \mathrm{Q}$.

ENVIRONMENT CANADA. Canadian Sediment Quality Guidelines for Protection of Aquatic Life. Summary Tables, 1999. http://www.ec.gc.ca. (15 jun. 2004).

ESTADOS UNIDOS. Department of agriculture. Soil Survey Division. Soil Conservation Service. Soil Survey Staff. Soil Taxonomy: a basic system of soil classification for making and surveys. 2.ed. Washington: USDA, 1999. 869p. (Agriculture Handbook, 436).

FANNING, D.S.; KERAMIDAS, V.Z.; EL-DESOKY, M.A. Micas. In: DIXON, J.B., WEED, S.B. (Ed.). Minerals in soils environments. 2. ed. Madison: SSSA, 1989. p.551-634.

FERRER, L.M. Fixação e mobilidade de espécies de mercúrio no sistema sedimento/água do mangue no município de Cubatão, São Paulo. São Paulo, 2001. 122p. Dissertação (Mestrado) - Instituto de Geociências, Universidade de São Paulo. 
FERREIRA, T.O. Solos de mangue do rio Crumahú (Guarujá-SP): pedologia e contaminação por esgoto doméstico. Piracicaba, 2002. 113p. Dissertação (Mestrado) - Escola Superior de Agricultura "Luiz de Queiroz", Universidade de São Paulo.

FIRME, L.P. Caracterização físico-química de solos de mangue e avaliação de sua contaminação por esgoto doméstico via traçadores fecais. Piracicaba, 2003. 70p. Dissertação (Mestrado) - Escola Superior de Agricultura "Luiz de Queiroz", Universidade de São Paulo.

FÖRSTNER, U. Inorganic sediment chemistry and elemental speciation. In: BAUDO, R.; GIESY, J.; MUNTAU, H. (Ed.). Sediments: Chemistry and Toxicity of In-place Pollutants. Secta-Europe: Pallaza, 1990. p.61-105.

FÖRSTNER, U.; WITTMAN, G.T.W. Metal pollution in the aquatic environment. 2 ed. Springer - Verlag, Berlin Heldelberg. New York: revised, 1981. 486p.

FORTÍN, D.; LEPPARD, G.G.; TESSIER, A. Characteristic of lacustrine diagenetic iron oxyhydroxides. Geochimica Cosmochimica Acta, v.57, p.4391-4404, 1993.

GAMBREL, R.P.; PATRICK, W.H. Chemical and microbiological properties of anaerobic soils and sediments. In: HOOK, D.D.; CRAWFORD, R.M.M. (Ed.). Plant life in anaerobic environments. Michigan: Ann Arbor, 1978. p.375-423.

GIBLIN, A.E.; LUTHER, G.W.; VALIELA, I. Trace metals in salt marsh sediments contaminated with sewage sludge. Estuarine Coastal and Shelf Science, v.23, p.477-498, 1986.

GRAEDEL, T.E.; ALLENBY, B.R. Industrial ecology. Englewood Cliffs: Prentice Hall, 1995. 412 p. 
GREENWOOD, D.J. The effect of oxygen concentration on the decomposition of organic materials in soil. Plant and Soil, v.14, p.360-376, 1961.

GRIFFIN, T.M.; RABENHORTS, M.C.; FANNING, D.S. Iron and trace metals in some tidal marsh soils of the Chesapeake Bay. Soil Science Society American Journal, v.53, p.1010-1019, 1989.

HAN, B.C.; JENG, W.L.; HUNG, T.C., WEN, M.Y. Relationship between copper speciation in sediments and bioaccumulations by marine bivalves of Taiwan. Environmental Pollution, v.91, p.35-39, 1996.

HARE, L.; CARIGNAN, R.; HUERTA-DÍAZ, M.A. A field study of metal toxicity and accumulation by benthic invertebrates; implications for acid-volatile sulfide (AVS) model. Limnology and Oceanography, v.39, p.1653-1668, 1994.

HART, M.G.R. Sulphur oxidation in tidal mangrove soils of Sierra leone. Plant Soil, v.3, p.215-236, 1959.

HAVLIN, J.L.; BEATON, J.D.; TISDALE, S.L.; NELSON, W.L. Soil Fertility and Fertilizers: introduction to nutrient management. 6 ed. New jersey: Prentice Hall, 1999. 499p.

HERS, R. Os manguezais do Brasil. São Paulo: IOUSP-CIRM, 1991. 233p.

HINES, M.E.; KNOLLMEYER, S.L.; TUGEL, J.B. Sulfate reduction and other sedimentary biogeochemistry in a northern New England salt marsh. Limnology and Oceanography, v.34, p.578-590, 1989. 
HOWARTH, R.W. Pyrite: Its rapid formation in a salt marsh and its importance in ecosystem metabolism. Science, v.203, p.49-51, 1979.

HOWARTH, R.W. The ecological significance of sulfur in the energy of salt marsh and coastal marine sediments. Biogeochemistry, v.1, p.5-27, 1984.

HOWARTH, R.W.; HOBBIE, J.E. The regulation of decomposition and heterotrophic microbial activity in salt marsh soils. A review. In: KENNEDY, V.S. (Ed.). Estuarine comparasions. New York: Academic Press, 1982. p.103-127.

HOWELER, R.H. The oxygen status of lake sediments. Journal of Environmental Quality, v.1, p.366-372, 1992

HUERTA-DÍAZ, M.A.; MORSE, J.W. A quantitative method for determination of trace metal concentrations in sedimentary pyrite. Marine Chemistry, v.29, p.119-114, 1990.

HUERTA-DÍAZ, M.A.; MORSE, J.W. Pyritization of trace metals in anoxic marine sediments. Geochimica Cosmochimica Acta, v.56, p.2681-2702, 1992.

HUERTA-DÍAZ, M.A.; CARIGNAN, R.; TESSIER, A. Meansurement of trace metals associated with acid volatile sulfide and pyrite in organic freshwater sediments. Environment Science Technology, v.27, p.2367-2372, 1993.

HUERTA-DÍAZ, M.A.; TESSIER, A.; CARIGNAN, R. Geochemistry of trace metals associated with reduced sulfur in freshwater sediments. Applied Geochemistry, v.13, p.113-233, 1998. 
JENNE, E.A. Controls on $\mathrm{Mn}, \mathrm{Fe}, \mathrm{Cu}, \mathrm{Ni}, \mathrm{Zn}$ concentrations in soils and waters: significant role of hydrous $\mathrm{Mn}$ and Fe oxides. Advances in Chemistry, v.73, p.337$387,1968$.

JIMENEZ, J.A. Rhizophora mangle: red mangrove. Rio Piedras: Institute of Tropical Forestry; UNESCO, 1985. 7p.

JIMENEZ, J.A. Laguncularia racemosa: white mangrove. Rio Piedras: Institute of Tropical Forestry; UNESCO, 1988. 4p.

JIMENEZ, J.A.; LUGO, A.E. Avicennia germinans: black mangrove. Rio Piedras: Institute of Tropical Forestry; UNESCO, 1988. 6p.

KABATA-PENDIAS, A.; PENDIAS, H. Trace elements in soils and plants. Boca Raton: CRC Press, 2001. 413p.

KIRATLI, N.; ERGUIN, M. Partitioning of heavy metals in surface Black Sea sediments. Applied Geochemistry, v.11, p.775-788, 1996.

KNOX, A.S.; GAMERDINGER, A.P.; ADRIANO, D.C.; KOLKA, R.K.; KAPLAN, D.I. Sources and practices contributing to soil contamination. In: ADRIANO, D.C.; BOLLAG, J.M.; FRANKENBERGER JUNIOR, W.T.; SIMS, R.C. (Ed.). Bioremediation of contaminated soils. Madison: ASA/CSSA/SSSA, 1999. p.53-89. (Agronomy Monograph, 37).

KOSTKA, J.E.; LUTHER, G.W. Partitioning and speciation of soil phase iron in saltmarsh sediments. Geochimica Cosmochimica Acta, v.58, p.1701-1710, 1994. 
KRAUSKOPF, K.B. Factors controlling the concentrations of thirteen rare metals in sea waters. Geochimica Cosmochimica Acta, v.9, p.1-32, 1956.

LACERDA, L.D. Biogeochemistry of trace metal and diffuse pollution in mangrove ecosystems. Okinawa: International Society for Mangrove Ecosystems, 1998. 68p.

LACERDA, L.D. Uso potencial de manguezais como mitigadores da contaminação por metais pesados em ambientes costeiros tropicais. In: REUNIÃO ANUAL DA SOCIEDADE BRASILEIRA PARA O PROGRESSO DA CIÊNCIA, 53., Salvador, 2001. Anais. São Paulo: SBPC, 2001. p.1-7.

LACERDA, L.D.; ABRÃO, J.J. Heavy metal accumulation by mangrove and Salt Marsh intertidal sediments. Revista Brasileira de Botânica, v.7, p.49-52, 1984.

LACERDA, L.D.; ITTEKKOT, V.; PATCHINEELAM, S.R. Biogeochemistry of mangrove soil organic matter: a comparison between rhizophora and Avicennia soils in Southern Brazil. Estuarine, Coastal \& Shelf Science, v.40, p.713-720, 1995.

LACERDA, L.D.; REZENDE, C.E.; OVALLE, A.R.C.; CARVALHO, C.E.V. Mercury distribution in continental shelf sediments from two offshore oil fields in southeastern Brazil. Bulletin of Environmental Contamination and Toxicology, v.72, p.178-185, 2004.

LACERDA, L.D.; CARVALHO, C.E.V.; TANIZAKI， K.F.; OVALLE， A.R.; REZENDE, C.E. The biogeochemistry and trace metals distribution of mangrove rhizospheres. Biotropica, v.25, p.252-257, 1993. 
LACERDA, L.D.; MARTINELLI, L.A.; REZENDE, C.A.; MOZETTO, A.A.; OVALLE, A.R.C.; VICTORIA, R.L.; SILVA, C.A.R.; NOGUEIRA, F.B. The fate of trace metals in suspended matter in a mangrove creek during a tidal cycle. Science Total Environmental, v.75, p.249-259, 1988.

LAMBERTI, A. Contribuição ao conhecimento da ecologia das plantas do manguezal de Itanhaém. São Paulo, 1966. 217p. Tese (Doutorado) - Faculdade de Filosofia, Ciências e Letras, Universidade de São Paulo.

LECHLER, P.J.; MILLER, J.R.; HSU, L.C.; DESILETS, M.O. Mercury mobility at the Carson river superfund site, west-central Nevada. USA: interpretation of mercury speciation data in mill tailings, soils, and sediments. Journal of Geochemical Exploration, v.58, p.259-267, 1997.

LEIROS DE LA PEÑA, M.C.; GUITIÁN, F.O. Suelos de la zona húmeda española. XI Contribución al estudio de los suelos hidromorfos de Galicia. I. Suelos costeros. Anales Edafologia Agrobiologia, v. 9/10, p.1707-1734, 1981.

LEPSCH, I.; SAKI, E.; PRADO, H.; RIZZO, L.T.B. Levantamento de reconhecimento de média intensidade dos solos da Região do Rio Ribeira de Iguape no Estado de São Paulo. Campinas: Instituto Agronômico, 1998. Mapa avulso. Escala 1:250.000.

LONG, S.P.; MASON, C.F. Saltmarsh Ecology. New York: Blackie, 1983. 159p.

LOVELY, D.R.; PHILLIPS, E.J.P. Availability of ferric iron for microbial reduction in botton sediments of the freshwater tidal Potomac river. Applied and Environmental Microbiology, v.52, p.751-757, 1986. 
LUOMA, S.N.; BRYAN, G.W. A statistical assessment of the form of trace metals in oxidized estuarine sediments employing chemical extractants. Science Total Environmental, v.17, p.165-196, 1981.

LUTHER, G.W. Pyrite synthesis via polysulfide compounds. Geochimica Cosmochimica Acta, v.55, p.2839-2849, 1991.

LUTHER, G.W.; MEYERSON, A.L.K.; HIRES, R. Metal sulfide in estuarine sediments. Journal of Sedimentary Petrology, v.50, p.1117-1120, 1980.

MARINS, R.V.; LACERDA, L.D.; PARAQUETTI, H.H.M.; DE PAIVA, E.C.; VILLAS BOAS, R.C. Geochemistry of mercury in sediments of a sub-tropical coastal lagoon, Sepetiba Bay, southeastern Brazil. Bulletin of Environmental Contamination and Toxicology, v.61, p.57-64, 1998.

MARINS, R.V.; PAULA FILHO, J.; MAIA, S.R.; LACERDA, L.D., MARQUES, W.S. Distribuição de mercúrio total como indicador de poluição urbana e industrial na costa brasileira. Química Nova, v.27, n.5, p.763-770, 2004.

MARIUS, C.; LUCAS, J. Holocene mangrove swamps of West Africa: sedimentology and soils. Journal African Earth Science, v.12, p.41-54, 1991.

McBRIDE, M.B. Environmental chemistry of soils. New York: Oxford University Press, 1994. 406p.

McKEE, K.L.; MENDELSSOHN, I.A.; HESTER, M.W. Examination of pore water sulfide concentrations and redox potentials near the aerial roots of Rhizophora mangle and Avicennia germinans. American Journal of Botany, n.75, v.9, p.1352$9,1988$. 
MENEZES, L. F. T.; PEIXOTO, A. L.; MACIEL, N. C. A riqueza ameaçada do mangue. Ciência Hoje, v.27, n. 158, p.63-67, 2000.

MOLISANI, M.M.; CARVALHO, C.E.; SALOMÃO, M.S.M.B.; LACERDA, L.D.; OVALLE, A.R.C.; REZENDE, C.E. Heavy metals in sediments of the lower Paraíba do Sul river and estuary, southeastern Brazil. Bulletin of Environmental Contamination and Toxicology, v.63, p.682-690, 1999.

MORSE, J. W. Interactions of trace metals with authigenic sulfide minerals: implications for their bioavailability. Marine Chemistry, v. 46, p. 1-6, 1994.

MORSE, J.W.; LUTHER, G.W. Chemical influences on trace metal-sulfide interactions in anoxic sediments. Geochimica Cosmochimica Acta, v.63, p.3373-3378, 1999.

MORSE, J. W.; MILLERO, F.J.; CORNWELL, J.C.; RICKARD, D. The chemistry of hydrogen sulfide and iron sulfide systems in natural waters. Earth-Science Reviews, v.24, p. 1-42, 1987.

MUCCI, A. Manganese uptake during calcite precipitation from seawater: Conditions leading to the formation of a pseudokutnahorite. Geochimica Cosmochimica Acta, v.52, p.1859-1868, 1988.

NEGREIROS, O.C.; CARVALHO, C.T.; CESAR, S.F.; DUARTE, F.R.; DESHLER, W.O.; THELEN, K.D. Plano de manejo para o Parque Estadual da Ilha do Cardoso. Boletim Técnico do Instituto Floresta, v.9, p.1-57, 1974.

NGIAM, L.S.; LIM, P.E. Speciation of heavy metals in tropical estuarine anoxic and oxidized sediments by different sequential extraction schemes. Science Total Environmental, v.275, p.53-61, 2001. 
NIREL, P.M.V.; MOREL, F.M.M. Pitfalls of sequential extractions. Water Research, v.24, p.1055-1056, 1990.

NRIAGU, J.O. A history of global metal pollution. Science, v.272, p.223-224, 1996.

OTERO-PÉREZ, X.L. Biogeoquímica de metales pesados en ambientes sedimentarios marinos: I- Fluvisoles de la Ría de Ortigueira (NO Península Ibérica). II- Sedimentos de la Fosa hidrotermal de Guaymas (Golfo de California - México). Santiago de Compostela, 2000. 308p. Tese (Doutorado) - Universidad de Santiago de Compostela.

OTERO, X.L.; MACÍAS, F. Spatial variation in pyritization of trace metals in salt marsh soils. Biogeochemistry, v. 62, p. 59-86, 2001.

OTERO, X.L.; MACÍAS, F. Variation with depth and season in metal sulfides in salt marsh soils. Biogeochemistry, v. 61, p. 247-268, 2002 a.

OTERO, X.L.; MACÍAS, F. Spatial and seasonal variation in heavy metals in interstitial water of salt marsh soils. Environmental Pollution, v.120, p. 183-190, 2002 b.

OTERO, X.L.; HUERTA-DÍAZ, M.A.; MACÍAS, F. Heavy metals geochemistry of saltmarsh soils from the ría de Ortigueira (mafic and ultramafic area, NW Iberian Peninsula). Environmental Pollution, v.110, p. 285-296, 2000 a.

OTERO, X.L.; SÁNCHEZ, J.M.; MACÍAS, F. Bioaccumulation of heavy metals in thionic fluvisols by a marine polychaete (Nereis diversicolor): The role of metal sulfide. Journal of Environmental Quality, v.29, p.1133-1141, 2000 b. 
OTERO, X.L.; HUERTA-DÍAZ, M.A.; MACÍAS, F. Influence of a turbidite deposit on the extent of pyritization of iron, manganese and trace metals in sediments from the Guaymas Basin, Gulf of California (Mexico). Applied Geochemistry, v.18, p.11491163, 2003.

PANITZ, C.M.N. Ecological aspects of a salt marsh ecosystem in Santa Catarina Island (Brazil). In: SEELIGER, U. (Ed.). Coastal Plant Communities of Latin America. New York: Academic Press, 1992. p.213-230.

PATRICK, W H. Junior; MAHAPATRA, I.C. Transformation and availability of nitrogen and phosphorus in waterlogged soils. Advances in Agronomy, v.20, p. 323-359, 1968.

PATRICK, W.H. Junior; JUGSUJINDA, A. Sequential reduction and oxidation of inorganic nitrogen, manganese, and iron in flooded soil. Soil Science Society American Journal, v.56, p.1071-1073, 1992.

PEIXOTO, A.R.P. Análise simultânea da produção primária das comunidades de macrófitas emergentes dominantes das marismas do estuário da Lagoa dos Patos, RS. Porto Alegre, 1997. 112p. Dissertação (Mestrado) - Centro de Ecologia, Universidade Federal do Rio Grande do Sul.

PEIXOTO, A.R.P.; COSTA, C.S.B. Produção primária líquida aérea de Spartina densiflora Brong. (Poaecea) no estuário da laguna dos Patos, Rio Grande do Sul, Brasil. Iheringia, Série Botânica. (no prelo).

PHILLIPS, D. J. H. The use of biological indicator to monitor trace metal pollution in marine and estuarine environments, a review. Environmental Pollution, v.13, p.281-317, 1977. 
PIERZYNSKI, G.M.; SIMS, J.T.; VANCE, G.F. Soils and environmental quality. Boca Raton: Lewis Publishers, 1994. 313p.

PONNAMPERUMA, F.N. The chemistry of submerged soil. Advances in Agronomy, v.24, p.29-96, 1972.

POSTMA, D., The reactivity of iron oxides in sediments: A kinetic approach. Geochimica Cosmochimica Acta, v.57, p.5027-5034, 1993.

POSTMA, D.; JAKOBSEN, R. Redox zonation: Equilibrium constraints on the $\mathrm{Fe}(\mathrm{III}) / \mathrm{SO}_{4}{ }^{-}$reduction interface. Geochimica Cosmochimica Acta, v.60, p.3169$3175,1996$.

POR, F. D. Guia Ilustrado do Manguezal. São Paulo: Instituto de Biociências da Universidade de São Paulo, 1994. 82p.

PRADA-GAMERO, R.M. Mineralogia, físico-química e classificação dos solos de mangue do Rio Irirí no canal de Bertioga (Santos, SP). Piracicaba, 2001. 76p. Dissertação (Mestrado) - Escola Superior de Agricultura "Luiz de Queiroz", Universidade de São Paulo.

PRADA-GAMERO, R.M.; VIDAL-TORRADO, P.; FERREIRA, T.O. Mineralogia e físico-química dos solos de mangue do Rio Irirí no canal de Bertioga (Santos, SP). Revista Brasileira de Ciência do Solo, v.28, p.233-243, 2004.

PRAKASA, R.M.; SWAMY, A.S.R. Clay mineral distribution in the mangrove of the Godavari delta. Clay Research, v.6, n.2, p.81-86, 1987. 
PRAHARAJ, T.; FORTÍN, D. Determination of Acid Volatile Sulfides and Chromium Reducible Sulfides in $\mathrm{Cu}-\mathrm{Zn}$ and $\mathrm{Au}$ Mine Tailings. Water, Air, and Soil Pollution, v.155, p.35-50, 2004.

PRICE, J.; EWING, K.; WOO, M.K.; KERHSAW, K.A. Vegetation patterns in James Bay coastal marshes. II. Effects of hydrology on salinity and vegetation. Canadian Journal Botany, v.66, p.2586-2594, 1988.

RAI, D.; EARY, L.E.; ZACHARA, J.M. Environmental chemistry of chromium. Science Total Environmental, v.86, p.15-23, 1989.

QUINTÁS-MOSTEIRO, I. Caracterización y posibilidades de recuperación de antrosoles de canteras y minas de Galicia. Ph.D. Diss., Universidad de Santiago de Compostela, 1997.

RAIJ, B. van Fertilidade do solo e adubação. Campinas: Editora Agronômica Ceres, 1991. 343p.

RAMAMOORTHY, S.; CHENG, T.C.; KUSHNER, D.J. Effect of microbial life stages on methylmercury in natural waters. Bulletin of Environmental Contamination and Toxicology, v.29, p.167-173, 1982.

REDDY, K.R.; FEIJTEL, T.C.; PATRICK, W.H. Effect of soil redox conditions on microbiological oxidation of organic matter. In: The role organic matter in modern agriculture. CHEN, Y.; AVNIMELECH, Y. (Ed.). Dordrecht: Martins Nijhoff Publ., p.117-156, 1986. 
REZENDE, C.E.; LACERDA, L.D.; OVALLE, A.R.C.; CARVALHO, C.E.V.; SOUSA, C.M.M. The effect of an oil drilling operation on the trace metal concentrations in offshore bottom sediments of the Bacia de Campos oil field, SE Brazil. Marine Pollution, v.44, p.680-684, 2002.

RICKARD, D.; LUTHER, G.W. Kinetics of pyrite formation by the $\mathrm{H}_{2} \mathrm{~S}$ oxidation of iron (II) monosulfide in aqueous solutions between 25 and $125^{\circ} \mathrm{C}$ : The mechanism. Geochimica Cosmochimica Acta, v.61, p.135-147, 1997.

RITSEMA, C.J.; GROENENBERG, J.E. Pyrite oxidation, carbonate weathering and gypsum formation in a drained potential acid sulfate soil. Soil Science Society American Journal, v.57, p.968-976, 1993.

ROBIE, R.A. Thermodynamic properties of minerals. In: CLARK, S.P. (Ed.).

Handbook of Physical Constants. USA: Memoir 97 Geological Society of America, 1966. p.437-458.

SÁNCHEZ, J.M.; OTERO, X.L.; IZCO, J. Relationships between vegetation and environmental characteristics in a saltsmarsh system on coast of Northwest Spain. Plant Ecology, v.136, p.1-8, 1998.

SÁNCHEZ, J.M. Caracterización florística y fitosociológica de las rías de Ortigueira y Ladrido (NW de la Península Ibérica) en relación con factores ambientales. Santiago de Compostela, 1995. 232p. Tesis (Doctoral). Facultad de Farmacia, Universidad de Santiago de Compostela.

SCHAEFFER-NOVELLI, Y. Os Manguezais de Cananéia $\left(25^{\circ} \mathrm{S}\right.$, Brasil). II - Um projeto integrado para avaliação do Ecossistema/Estrutura. Revista Atlântica, v.2, n.5, p.108, 1982. 
SCHAEFFER-NOVELLI, Y. Manguezais Brasileiros. São Paulo, 1991. 42p. Tese (Livre-Docência) - Instituto Oceanográfico, Universidade de São Paulo.

SCHAEFFER-NOVELLI, Y. Manguezal: Ecossistema entre a Terra e o Mar. São Paulo: Caribbean Ecological Research. 1995. 64p.

SCHAEFFER-NOVELLI, Y. Avaliação e ações prioritárias para a conservação da biodiversidade da zona costeira e marinha. http://www.bdt.org.br. (10 ago. 1999).

SCHOER, J. Iron-oxo-hydroxides and their significant to the behavior of heavy metals in estuarines. Environment Technology, v.6, p.189-202, 1985.

SILVA, I.X.; MORAES, R.P.; SANTOS, R.P.; MARTINS, S.E.; POMPÉIA, S.L. A degradação dos ecossistemas da Baixada Santista, São Paulo. In: SIMPÓSIO DE ECOSSISTEMAS DA COSTA BRASILEIRA, 3., Serra Negra, 1993. Anais. Serra Negra: ACIESP, 1994. p.30-38.

SINGER, C.E.; HAVILL, D.C. Resistence to divalent manganese of salt-marsh plants. Journal Ecology, v.81, p.197-206, 1993.

SLADEK, C.; GUSTIN, M.S. Evaluation of sequential and selective extraction methods for determination of mercury speciation and mobility in mine waste. Applied Geochemistry, v.18, p.567-576, 2003.

SECRETARIA DO MEIO AMBIENTE, São Paulo. Projeto DPRN (1994) - Estudo preliminar não concluído. Diretoria de Assuntos Metropolitanos: Mata Atlântica. $\begin{array}{lllll}\text { Secretaria do } & \text { Meio } & \text { Ambiente. }\end{array}$ http://www.unisantos.br/ metropms/caruara/vegeta2.htm. (3 dez. 2001). 
SECRETARIA DO MEIO AMBIENTE, São Paulo. Mapeamento dos Ecossistemas Costeiros do Estado de São Paulo. Secretaria do Meio Ambiente (SMA) São Paulo: Cia. de Tecnologia de Saneamento Ambiental - Cetesb, 1999. 108p.

SMILLIE, R.H.; HUNTER, K.; LOUTIT, M. Reduction of chromium (IV) by bacterially produced hydrogen sulphide in a marine environment. Water Research, v.15, p.1351-1354, 1981.

SMOAK, S.; PATCHINEELAM, S.R. Sedimentation rates in mangrove sediments from September bay. Brazil. Mangroves \& Salt Marshes, v.3, p.98-103, 1999.

SPANGLER, W.J.; SPIGARELLI, J.L.; ROSE, J.M.; FLIPPIN, R.S.; MILLAR, H.H. Degradation of methylmercury by bacteria isolated from environmental samples. Applied and Environmental Microbiology, v.25, p.488-493, 1973.

SPARKS, D.L. Environmental soil chemistry. San Diego: Academic Press, 1995. $267 p$.

STUMM, W.; MORGAN, J.J. Aquatic Chemistry. Ed.: John Wiley, 1981. 780p.

SUESS, E. Mineral phases formed in anoxic sediments by microbial decomposition of organic matter. Geochimica Cosmochimica Acta, v.43, p.3233-3257, 1979.

SUGIYAMA, M. A flora do manguezal. In: SCHAEFFER-NOVELLI, Y. (Ed.). Manguezal: ecossistema entre a terra e o mar. São Paulo: Caribbean Ecological Research, 1995. cap.4, p.17-21. 
SUNDBY, B.; VALE, C.; CAÇADOR, I.; CATARINO, F.; MADUREIRA, F.; CAETANO, M. Metal-rich concretions on roots of salt marsh plants: Mechanism and rate of formation. Limnology and Oceanography, v.43, p.245-252, 1998.

TAM, N.F.Y.; WONG, Y.S. Retention and distribution of heavy metals in mangroves soils receiving wastewater. Environmental Pollution, v.94, p.283-291, 1996.

TESSIER, A.; CAMPBELL, P.G.C.; BISSON, M. Sequencial extraction procedure for the speciation of particulate trace metals. Analytical Chemistry, v.51, p.844-855, 1979.

TESSIER, A.; CAMPBELL, P.G.C.; AUCLAIR, J.C.; BISSON, M. Relationship between the partitioning of trace metals in sediments and their accumulations in the tissues of the freshwater mollusk Elliptio complanata in a mining area. Canadian Journal of Fish and Aquatical Science, v.41, p.1463-1472, 1984.

TOMMASI, L.R. Considerações ecológicas sobre o sistema estuarino de Santos (SP). São Paulo, 1979. 489p. Tese (Livre Docência) - Instituto Oceanográfico, Universidade de São Paulo.

TURNER, F.T.; PATRICK JUNIOR, W.H. Chemical changes inn waterlogged paddy soils as a result of oxygen depletion. In: CONGRESS SOIL SCIENCE IV, 9., Adelaide: Halstead Press, 1968. p.53-65.

URE, A.M. Trace elements in soil: their determination and speciation, Fresenius Journal of Analytical Chemistry, v.337, p.57-581, 1990.

VALIELA, I.; VINCE, S.; TEAL, L.M. Assimilation of sewage by wetlands. In: Estuarine processes. New York: Academic Press., 1976. p.234-253. 
VAN CALSTEREN, P.W.C. Geochemistry of the polymetamorphic mafic-ultramafic complex at Cabo Ortegal (NW Spain). Lithos, v.11, p.61-72, 1978.

VANNUCCI, M. Os Manguezais e Nós. São Paulo: EDUSP, 1999. 296p.

WALSH, G. E. "Mangroves: a review". In: REINOLD, R.J.; QUEEN, W.H. (Ed.). Ecology of Halophytes. New York: Academic Press, 1974. p.51-154.

WEBER, J.H.; EVANS, R.; JONES, S.H.; HINES, M.E. Conversion of mercury (II) into mercury (0), monomethylmercury cation, and dimethylmercury in saltmarsh sediment slurries. Chemosphere, v.7, p.1669-1687, 1988.

WIEGERT, R.G.; POMEROY, L.R.; WIEBE, W.J. Ecology of salt marsh: An Introduction. In: The ecology of a salt marsh. New York: Springer - Verlag, 1981. p.3-18.

ZAGGIA, L.; ZONTA, R. Metal-sulphide formation in the contaminated anoxic sludge of the Venice canals. Applied Geochemistry, v.12, p.527-536, 1997.

ZHANG, Y.L.; EVANGELOU, V.P. Influence of iron oxide porming conditions on pyrite oxidation. Soil Science, v.161, p.852-864, 1996. 